\title{
THE GALLO CASE
}




\section{CONTENTS}

Introduction

365

I. The Crewdson Article 369

II. The NAS-Nominated Panel $\mathbf{3 7 5}$

III. The OSI "Inquiry" $\mathbf{3 7 9}$

IV. Interlude: Scientific Responsibility 385

v. The OSI Investigation $\quad 394$

VI. Abuse of the Richards Panel by NIH 409

VII. The Integrity of Scientific Consultation 420

VII. Interlude: Journalistic Obstructions 439

IX. An Exchange with Gallo 442

X. A Letter to Leaders of Science 467

XI. A Report by the HHS Office of Research Integrity (ORI)

469

XII. The HHS Appeals Board 480

XIII. Interlude: Motives, Intent, and Misconduct 523

XIV. The Dingell Subcommittee Hearings of 21 July 1993

528

XV. The HHS Inspector General, the U.S. Attorney, and the IG's Memorandum

531

XVI. Developments February-July 1994

XVII. The Dingell Subcommittee Staff Report 555 


\section{INTRODUCTION}

The Gallo case concerns the discovery of a virus called HIV in 1983-1984. The official establishment position up to now is that this virus causes AIDS. Since 1983-1984, there has been a controversy between Robert Gallo, Chief of a major laboratory of the National Institutes of Health (NIH), and scientists of the Institut Pasteur in Paris, concerning who discovered this virus and how it was developed in a form usable for a blood test. Following the breakdown of informal negotiations, the French instigated a patent suit on the matter. In fact, they launched four separate legal proceedings, including a patent "interference."

\section{Investigations of Gallo}

The Chicago Tribune has played a major role in causing investigations of the case, starting with a nearly book-length article (over 50,000 words) by one of its reporters John Crewdson, on 19 November 1989. Numerous articles by Crewdson appeared since, including an overall "Perspective" of the case on 6 December 1992 (nearly three full pages in the Chicago Tribune). Crewdson was backed by strong editorial support from the beginning. His "Perspective" of 6 December 1992 was accompanied by three supportive editorial statements, which I recommend as exemplary accounts of journalistic responsibility. After examining the performance of the scientific press (or the press at large) compared to that of the Chicago Tribune, I have concluded that the Chicago Tribune and Crewdson achieved one of the major journalistic contributions in decades, and that they have set standards of depth, thoroughness, and accuracy in journalism which the scientific press might well emulate.

Investigations of the Gallo case took place in several ways.

1. At first, the NIH Office of Scientific Integrity (OSI) (created in 1989) carried its own investigation, with Suzanne Hadley as chief investigator. Shortly after Bernadine Healy became director of the 
NIH in 1991, she forced Hadley's resignation, and in 1992 the OSI was abolished and replaced by the Office of Research Integrity (ORI), directly responsible to the Assistant Secretary of Health, James Mason at the time. Thus the ORI exists within the HHS but outside the NIH.

2. The OSI's investigation cleared Gallo of all "misconduct," but found some specific problems with his conduct. The ORI's investigation arrived at mixed conclusions in December 1992. Gallo was partly exonerated on some counts, but was deemed guilty of "misconduct" on others.

3. Gallo appealed to the HHS Appeals Board in 1993. The ORI had also instituted proceedings against one of Gallo's laboratory coworkers, Mikulas Popovic. The Appeals Board ruled in favor of Popovic, against ORI. As a result of many factors, including certain conditions imposed by this Board, and the ruling in favor of Popovic, the ORI withdrew all charges against Gallo in November 1993. However, ORI had prepared an "Offer of Proof" which it intended to submit to the Appeals Board. This Offer of Proof documents many aspects of the case against Gallo, and has lists of a number of scientists who had offered to cooperate with ORI and to testify against Gallo. ${ }^{1}$

4. The HHS Inspector General requested a prosecution, which was declined by the U.S. Attorney in Baltimore, MD. The U.S. Attorney wrote back a letter to the HHS Inspector General, declining to prosecute, for many reasons. In addition, this letter stated: "In deciding not to seek prosecution, we recognize that this case transcends the normal type of criminal case, and that the conduct of these two noted scientists [Gallo and Popovic] reflects upon the integrity of the scientific process, the National Cancer Institute, and indeed the conduct of our government as a whole. However compelling is the need to provide a forum for historical accuracy on these issues, that noble desire cannot be a substitute for evidence, nor does it justify using the criminal courts in place of the court of public opinion." Thus the community at large was left with the alternative of going back to the original Inspector General's Memorandum to find out some facts (see XV and XVI).

5. Throughout this period, Representative John Dingell carried out his own hearings and investigation. Suzanne Hadley, who was still formally employed by HHS, was detailed to provide help and technical advice to Dingell's Subcommittee. She remained in

\footnotetext{
${ }^{1}$ This Offer of Proof is available under the Freedom of Information Act, directly from ORI (Freedom of Information Officer, ORI, Public Health Service, Rockville, MD 20857).
} 
that position until 15 April 1994. After that, she remained in touch with the Subcommittee and was the principal author of the Subcommittee's report. Because of the Republican victory in November 1994, the Dingell Subcommittee as such did not exist any more as of January 1995, and the previously written report was made available via the staff of the Subcommittee at that time. This Staff Report not only confirmed the findings of the HHS Inspector General's Memorandum and of the ORI Offer of Proof, but went beyond in documenting the case concerning Gallo and the U.S. Government and their actions in obtaining the patent for the HIV antibody blood test.

\section{The Role of Scientists}

As an academic and especially as a scientist, I am mostly concerned with issues of scientific responsibility within the scientific or academic community, including individual responsibilities and also the responsibilities of institutions, including the universities, the National Academy of Sciences, the government's scientific agencies, and the scientific press. I shall document my concerns with the way some scientists partly failed to meet their responsibilities, and partly were manipulated by governmental agencies and officials.

(a) The fiasco involving ORI, Popovic, and Gallo provides a significant illustration of problems which arise in trying to maintain scientific standards, the conflict between legal and scientific points of view, problems which arise as a result of witholding information, partly from attempts by some officials to cover up, partly from the incompetence of others, partly because of the interference of "legal" aspects, and for other multiple reasons, extensively documented throughout the following analysis of the Gallo case.

(b) At the beginning of the investigations by NIH and HHS, these governmental agencies publicly took the position that the cooperation of scientists was essential to ensure competence and credibility, and public steps were taken to bring scientists into the picture. Throughout the period, these scientists were manipulated, and their role was progressively diminished until they were completely eliminated in the final stage of certain rulings by the Appeals Board, which was constituted exclusively by lawyers.

I regard the entire performance by NIH and HHS as disgraceful, but a number of scientists also bear a heavy responsibility for not coming out into the open on the record against the manipulations 
to which they were subjected, and for not taking a clear public stand on the issues.

(c) Scientists at large rely for information mostly on the more or less official publications such as Science and Nature. These have done a tendentious and highly selective job of reporting. As a result scientists at large have been misinformed or disinformed.

(d) Scientists in general are busy with their research. For many reasons, including the misinformation or disinformation of the official scientific press, they have mostly been passive in the Gallo case, with a few notable exceptions, for example: Don Francis, John Edsall, Fred Richards off and on, and William Hagins after the Dingell Staff Report came out.

Different scientists reacted differently at different times, so no universal characterization appplies to all of them for all times. 


\section{THE CREWDSON ARTICLE}

On 19 November 1989, John Crewdson published a monumental 50,000 word article in the Chicago Tribune: "The Great AIDS Quest," subtitled: "Science under the microscope." This article raised questions about Gallo's role and the role of his laboratory in the discovery of a virus called the "AIDS virus." (The virus is called by this name because it was accepted almost universally after 1984 that this virus causes AIDS.) Several viruses bearing different names actually come into play. Some, called LAV, came from the Institut Pasteur in Paris. Others allegedly came from Gallo's Laboratory of Tumor Cell Biology (LTCB), depending on the National Institutes of Health. These other viruses bear other names such as HTLV-III or MOV. ${ }^{1}$ Crewdson's article gave extraordinary and extensive factual reporting, and bore on several problematic aspects, especially two of them.

Misappropriation or contamination. One of the issues was whether certain viruses used by Gallo in his blood test were

\footnotetext{
${ }^{1}$ Crewdson's article had a precursor. In 1987, Steve Connor published two articles in the British magazine The New Scientist, 12 February 1987: a ten-page article: "AIDS: Science stands on trial" (pp. 49-58), and a onepage article: "AIDS: Mystery of the missing data" (p. 19). Both pieces bore on the legal dispute between scientists of the Institut Pasteur in Paris, and the U.S. government, and on some of the issues later raised by Crewdson.

Connor brings up a number of very specific questionable items. For example, the one-page article mentions a letter "sent between scientists at the US's National Cancer Institute (NCI), in Maryland, which is at the centre of the dispute.... The copies of the letter provide powerful evidence that someone has tampered with scientific data. One copy shows that the NCI had photographs of the Pasteur's virus, called LAV, in December 1983, six months before the American institute announced the discovery of its AIDS virus, which its researchers called HTLV-III. In the other copy of the same letter, someone has erased this information."

The ten-page article deals with some details, pointing to the possibility that HTLV-III was the same as the French virus LAV. Subsequently, this was shown to be the case by a genetic sequencing analysis.
} 
originally due to the French scientists at the Institut Pasteur, and whether Gallo had misappropriated the French virus (or viruses). A question was raised whether the French virus had contaminated his own accidentally, or whatever other possibilities could arise. Crewdson went into considerable detail documenting some reasons why a certain virus claimed by Gallo to have been independently isolated in his laboratory, and used in his blood test, was actually the same as the French virus.

It is extremely difficult to summarize the Crewdson article, because of its comprehensiveness and technicality. Many people have had this difficulty. For instance, in the Washington Business Journal (6 August 1990) Philip Boffey, science editor for the New York Times is quoted as saying: "As far as Crewdson's takeout goes, I thought it was an outstanding job, but it was hard to know what to do with it. It isn't an easily summarized piece. We just decided we couldn't duplicate his work."

Information which came out subsequently confirmed Crewdson's documentation. Specifically:

(a) DNA sequencing analyses confirmed unambiguously that the virus used by Gallo for the blood test came from the French Institut Pasteur.

(b) The question of "contamination" was also settled. It turned out that there was not a single sample of French viruses sent to Gallo in September 1983 but two, called LAV-Lai and LAV-Bru, taken from two different patients in France. Both were sent to Gallo by the Institut Pasteur. Thus there was contamination in the French laboratory between their virus samples. However, this contamination in France did not affect the fact that Gallo used the French virus(es) LAV, whether it's Lai or Bru. These events were properly reported subsequently in the HHS Inspector General's Memorandum dated 10 June 1994 (p. 16, item 3, discussed in detail below in XV, §4), and were further confirmed in the Dingell Subcommittee Staff Report.

(c) Gallo himself in a letter to me brought out several specific points of contention. In my reply (see IX), I documented how he made false statements and improperly represented events. For instance, throughout 1985 and 1986, Gallo made repeated public statements quoted in the press, that "no one has been able to work with [the French] particles," that "the amount of virus Montagnier sent would not have been sufficient to infect a cell line," and that to suggest his viruses and the French virus were the same was "the height of outrage," because "it was physically impossible to grow the particular virus sent by Montagnier." Readers will find the precise documentation in our exchange of 
letters reproduced below. See especially footnotes 3,4 , and 5 of my reply, showing Gallo's statements to be false or misrepresentations. For instance, as I also bring up in my reply, successive drafts of the paper in which Gallo and coauthors announced their discovery of the so-called AIDS virus show that Gallo deleted sentences by Popovic acknowledging indebteness to the Institut Pasteur. These deletions were later mentioned in the ORI Offer of Proof (see XII, Appendix 3, especially pp. 86 and 87), as well as in the HHS Inspector General's Memorandum of 10 June 1994 (see the item referring to 30 March 1984 in the chronology of events), and the Dingell Staff Report.

Gallo's patent application for the blood test. Another issue was the legitimacy of Gallo's patent applications for his blood test. Some of the points Crewdson covered in his original article of 19 November 1989 were repeated in his subsequent article "Inquiry hid facts on AIDS research" (Chicago Tribune, 18 March 1990, p. 17), where Crewdson wrote:

A secret government inquiry four years ago into the AIDS research of Dr. Robert C. Gallo uncovered evidence that he was not the discoverer of the first AIDS virus and that the virus from which he later developed a patented blood test for AIDS was probably the same one isolated nearly a year before at the Pasteur Institute in Paris.

But legal briefs later filed by the government in the U.S. Court of Claims and before the Patent and Trademark Office nonetheless concluded that Gallo was the first to identify the cause of AIDS and develop the AIDS test, and that the culture from which the test was made could not have been contaminated by a sample of the French AIDS virus sent to him by Pasteur researchers.

The briefs also reflect many of the misstatements and omissions about the AIDS research conducted by Gallo and the Pasteur scientists contained in a confidential 1985 report prepared by a senior official of the National Cancer Institute for use in defending the government against impending legal actions by the French.

According to a copy of the report and related documents obtained by the Tribune, these are among the numerous legal claims unsupported by Gallo's laboratory records and other documents produced by the internal inquiry.

- That genetic evidence "conclusively" established that the Gallo AIDS virus was an independent isolate and not the 
same virus the French had earlier sent Gallo for testing.

- That Gallo actually discovered the AIDS virus a month before the Pasteur researchers but withheld news of his discovery for more than a year.

- That Gallo's lab was the first to develop a blood test that could accurately measure exposure to the AIDS virus and thus the lucrative patent on that test rightfully belonged to the U.S. government, not the French.

C. McLain Haddow, then chief of staff to Health and Human Services Secretary Margaret Heckler, said in a recent interview it was possible that the Justice Department lawyers had been denied the full facts about Gallo's research. ${ }^{2}$

"I feel like I'd been misled," Haddow said, "and there may have been people in the Justice Department who received information where they were misled. I couldn't sort it out and I don't think very many people could.... There was a point where it became very clear to me that the NIH people were not being truthful," Haddow recalled. "These people would sit down for one meeting and then in a subsequent meeting the stories were different.... They weren't even

${ }^{2}$ Haddow also surfaced later with comments putting into question the U.S. Government's case in the patent application. Dan Greenberg's Science and Government Report of 1 July 1992 has this to say:

HHS's nervousness about the Gallo case has been compounded by damaging statements by a former HHS official who was there when Gallo reaped glory as the discoverer of the AIDS virus, C. McClain Haddow, HHS Chief of Staff from 1983-87. Haddow's credibility is sullied by the fact that, in a matter unrelated to the Gallo case, he was convicted of violating federal conflict of interest regulations and imprisoned for four months. But his account of the Gallo affair has received a good deal of attention lately, with reports in the New York Times of June 25 [1992] and in a BBC production on the case, "Taking the Credit."

The Times report states that "Mr. Haddow now says that from the beginning some top HHS officials had doubts about Dr. Gallo's account [of the discovery of the AIDS virus]."

In the BBC production, Haddow states, "Well, the determination we finally came to after investigating it was that Bob Gallo, as strong as he was on his views, couldn't support the claims he was making from a legal standpoint.... The French attorneys ... didn't know how weak our case was and they never discovered it. So we were able to craft an agreement that probably disadvantaged the French, but it was because we hid our weakness fairly effectively. We felt in a political sense that it was important for President Reagan to show that he had an interest in the AIDS problem...." 
smart enough to get their stories straight before they talked to me," he said. "How in the world could they get through a court proceeding?"

In his articles, Crewdson also reported the existence of a 1985 report by Dr. Peter J. Fischinger, then the Cancer Institute's associate director. According to the article of 18 March 1990:

The [Fischinger] report includes a signed statement from Gallo attesting to the accuracy of the information it contains.

After Pasteur sued the U.S. government in December 1985 , its attorneys requested copies of all documents relating to Gallo's isolation of the AIDS virus under the Freedom of Information Act. Although more than 5,400 pages of records were ultimately produced, about 20 documents were withheld on the grounds that they were "deliberative" or "predecisional."

Among those withheld were three documents related in the Fischinger report, all marked "administrative confidential," written in August and September of 1985 as the government began laying the groundwork for its eventual defense against the French.

The three documents are a memo from Fischinger summarizing his findings to Lowell $\mathrm{T}$. Harmison, then a senior official of HHS; a memo from Fischinger to Gallo expressing the concerns of other government scientists about Gallo's work, and Gallo's reply to that memo.

Crewdson's article went on to relate in detail certain internal contradictions in all the memos going back and forth in 1985 .

Anticipating further developments. Subsequent investigations by OSI or its successor ORI (Office of Research Integrity) did not clear up all these contradictions. OSI referred questions having to do with the patent application to the HHS Office of the Inspector General, because, according to Suzanne Hadley, OSI was advised by this office that such questions might require a criminal investigation. As we shall see later, the Inspector General completed an investigation and asked the U.S. Attorney in Baltimore, MD, to start a prosecution, but the U.S. Attorney declined, leaving the responsibility directly on the scientific community (see $\mathrm{XV}$ and XVI).

Ultimately, the HHS Inspector General's Memorandum of 10 
June 1994 reported (p. 27, see XV, §4 below): “The [Patent Office] examiner advised the OIG [Office of the Inspector General] that, had she been aware of the IP [Institut Pasteur] prior art at the time she examined the blood test application of Gallo, she would have suspended prosecution of the Gallo application and declared an interference between the two applicants. An interference was eventually declared, but not until two years after the initial Gallo submission. The IP scientists were eventually named Senior Party in the interference, confirming their priority in submitting a patent application on the HIV antibody blood test. By the time the interference was declared, the Gallo patent had long since been issued."

These facts were confirmed in the Dingell Subcommitte Staff Report (see XVIII). 


\section{THE NAS-NOMINATED PANEL}

Under pressure from the Crewdson articles in the Chicago Tribune, NIH decided to look into the matter of Gallo's role in the discovery of the so-called "AIDS virus." To enhance the credibility of their Gallo investigation they thought of covering themselves with the prestige of a panel to be nominated by the National Academy of Sciences. In a letter dated 15 February 1990, James Mason, Assistant Secretary for Health and Acting Surgeon General, solicited NAS President Frank Press to nominate such a panel, "with a view to ensuring both the fact and appearance of objectivity for the inquiry." Mason was writing at the request of William Raub, Acting Director of NIH, and endorsed the request. Mason specified that "the panel would counsel NIH's Office of Scientific Integrity regarding the focus of the inquiry and the analysis of the findings. If a subsequent investigation proves necessary, the panel would be asked to continue its advisory role through that phase as well."

Frank Press replied on 22 February 1990 that a list of nominees would be provided within a few days, and also emphasized: "We note that you will draw the advisory panel exclusively from this list...." In addition, Frank Press cautioned: "Also, in view of the fact that the NAS and IOM [Institute of Medicine] are serving no role other than nominating individuals, with no further involvement or responsibilities involving our own institutional processes, it would be inappropriate to call this an NAS/IOM Committee, or to attribute any resulting report to the Academy. However, you may if you wish note that the committee was nominated by the Presidents of the NAS and IOM after consultation with a group of members of our institutions knowledgeable about the pertinent sciences."

The nomination of this panel received considerable publicity in the scientific press and elsewhere. I reproduce in a box some of the news items reporting its creation. 


\section{WHAT THEY SAID}

Former NIH director James B. Wyngaarden, now a deputy director of the White House Science Office, is among those who urged NIH officials to turn to outside observers in the hope that their oversight will preclude accusations that $\mathrm{NIH}$ is not entirely objective in its review....

Acting Director William Raub, along with Joseph E. Rall, director of intramural science, have asked Frank Press, president of the National Academy of Sciences, and Samuel O. Thier, president of the NAS's Institute of Medicine, to nominate a slate of qualified observers to verify the independence and thoroughness of the NIH's own investigation. According to the current scenario, a jury of peers would then be selected from the NAS-IOM panel by James $\mathrm{O}$. Mason, the assistant secretary for health. "We decided to go the 'extra mile' for the NIH's sake and for Dr. Gallo's," Raub told Science.

Press and Thier have agreed to propose such a panel with the stipulation that Mason confine his selection to that list and agree not to add anyone recommended by the government, which can be said to have a stake in the outcome because it is a signatory to the U.S.-French agreement....

"We'll be asking their advice on both the strategy of our review and the substance of the conclusions. We'll need some running room to do a thorough job."

"NIH Goes the 'Extra Mile' on Gallo" by Barbara Culliton, Science, 23 February 1990

We're trying to get the best outside people we can-the most serious, important people, who have no vested interest," said Dr. Joseph E. Rall the deputy NIH director for intramural research, who is in overall charge of the investigation. "We're determined to have the process above reproach."

"U.S. agency probing AIDS virus discovery" by John Crewdson, Chicago Tribune, 25 February 1990

Yale University biochemist Frederic M. Richards, who is described by colleagues as a man of exceptional integrity, has agreed to chair the committee. (Science, 30 March 1990.)

Sources say committee members have promised not to discuss their deliberations until they are complete. At that point, they expect to "speak out loud and clear." 
The nominated panel was chaired by Fred Richards, Professor of Molecular Biophysics and Biochemistry at Yale. The other members of the panel at the time were:

Judith Areen, Dean of the Georgetown University School of Law.

Stanley Falkow, Professor of Microbiology at Stanford University.

Alfred Gilman, Professor and Chairman of Pharmacology at the University of Texas Health Science Center.

Harry Gray, Professor of Chemistry and Director, Beckman Institute at Caltech.

Arnold J. Levine, Professor of Molecular Biology at Princeton University.

H. E. Morgan, Senior Vice President for Research at the Geisinger Clinic.

Mary Jane Osborn, Professor of Microbiology at University of Connecticut Health Center.

John D. Stobo, Professor and Chairman of Medicine at Johns Hopkins.

Joseph Sambrook, Professor and Chairman of Biochemistry at the University of Texas Southwestern Medical Center.

Robert Wagner, Professor of Oncology and Microbiology at the University of Virginia.

[Shortly thereafter, Stanley Falkow and Harry Gray dropped.out.]

The original charge to the panel was as follows:

I. To counsel the NIH on the focus and process of the inquiry, particularly the issues being examined.

II. To review the findings of the inquiry and recommend if a formal investigation of possible scientific misconduct is warranted-or-if the matter should be closed.

(If a formal investigation is initiated, members of the consultant panel will be asked to assist in the investigation.)

Note: A formal investigation would be called for if there is substantial reason to believe scientific misconduct may have occurred.

"Scientific misconduct" is defined as "fabrication, falsification, plagiarism, or other practices that seriously deviate from those that are commonly accepted within the scientific 
community for proposing, conducting, or reporting research. It does not include honest error or honest differences in interpretations or judgments of data." (42 CFR Part 50.) 


\section{THE OSI "INQUIRY"}

This NIH "inquiry" was done by an "Inquiry Team" which was part of the NIH Office of Scientific Integrity, referred to as OSI. As mentioned above, this "inquiry" was to determine whether a formal investigation was needed.

On 29 June 1990, Howard Morgan and Fred Richards wrote for their panel to William Raub, to recommend a formal investigation: "The panel met on June 7.... The Inquiry Team consisting of J. Hallum, S. Hadley, and P. Parkman presented a portion of their findings centered on the work of the laboratory in the period from April 1983 to August $1984 \ldots$. The panel voted unanimously to recommend the following action to you: termination of the inquiry phase of proceedings and institution of the formal investigation. This decision was based on the review of material presented at the meeting. Some data appeared to be missing from the data books. There is a possibility of selection and/or misrepresentation of data. There is a need for the panel to plan experiments on the viral samples that have been sequestered or that can be located...."

William Raub replied negatively on 23 July 1990, that it would be "premature" to go into a formal investigation. However, under pressure from the Richards Panel, such an investigation by OSI did start, and Suzanne Hadley headed this investigation.

An announcement of the investigation was made by the NIH Acting Director William Raub in a press release 5 October 1990. This press release was phrased in an ambiguous way. I reproduce it in full in a box. 


\section{STATEMENT \\ by Dr. William F. Raub \\ Acting Director \\ National Institutes of Health \\ October 5, 1990}

Inquiry Into HIV Research Conducted by Dr. Robert Gallo et al.

The NIH Office of Scientific Integrity has reported to me on the progress of its inquiry into research on human immunodeficiency virus conducted in the Laboratory of Tumor Cell Biology of the National Cancer Institute under the direction of Dr. Robert Gallo.

The inquiry has resolved certain of the publicized allegations and issues or shown them to be without substance. In particular, the inquiry team has concluded that Dr. Gallo had a substantial number of HIV detections and isolations from several different sources at the critical time that HTLV-IIIB (the principal virus isolated by the Gallo laboratory) and LAV (the virus isolated by the Pasteur Institute) were being grown in Gallo's laboratory.

I have determined, however, that certain issues identified during the inquiry phase warrant a formal investigation. The investigation will focus on several aspects of published reports from Dr. Gallo's laboratory, particularly the report published by Popovic et al., Science, May 1984. Subjects of the investigation are Dr. Gallo and Dr. Mikulas Popovic. The investigation will also include testing of a number of biological samples in an effort to determine the origins of HTLV-IIIB, the virus that Dr. Gallo and his colleagues used to develop the blood test for human immunodeficiency virus (HIV).

The investigation will be conducted by the Office of Scientific Integrity, with the assistance of a panel of expert scientific advisors drawn from the extramural research community. The consultants nominated by the National Academy of Sciences and the Institute of Medicine will continue to provide oversight and guidance as they did during the inquiry. 
We are here concerned with the two middle paragraphs, concerning doings in Gallo's laboratory, rather than the administrative aspects of the inquiry or investigation. The ambiguity of Raub's press release gave rise to conflicting reports in the press. ${ }^{1}$ Compare, for instance, the headline in the Washington Post, "NIH Bolsters Claim of AIDS Pioneer-Gallo all but cleared," with the New York Times headline: "U.S. Inquiry on Misconduct in Discovery of AIDS Virus." The Science article correctly noted: "And that left people baffled. What was NIH trying to say?" The Chicago Tribune also noted in a "Media watch" headline by James Warren: "AIDS controversy-Conflicting reports leave readers in a muddle."

In Raub's statement that "the inquiry has resolved certain of the public allegations or shown them to be without substance," there is an innuendo that Crewdson may have falsely made certain allegations because Crewdson's articles in the Chicago Tribune since November 1989 had been the principal cause for the renewed consideration given to the Gallo case. Crewdson tried to get a more precise explanation of what Raub meant in his press conference, and he checked with Raub directly. Raub then disclaimed having Crewdson in mind. I shall quote from Crewdson's article in an appendix to this section so readers have a more informed basis to evaluate Raub's statement. As a matter of journalistic and scientific responsibility, it was incumbent on Raub in his press release to make precise who made what "allegations" and when, as well as to give evidence why these allegations were deemed to be "without substance." Raub's failure to do so had elements of scientific and journalistic irresponsibility. His statement cannot even be called "false," because his statement had no

1 Press reports on these events include:

"U.S. Inquiry on Misconduct In Discovery of AIDS Virus," and

"U.S. Agency in Reversal, to Look Into Discovery of the AIDS Virus," New York Times, 6 October 1990, p. 1.

"Agency orders probe of AIDS researcher," Chicago Tribune, 6 October 1990 , p. 1; the same article also appeared on 7 October, p. 16.

"NIH Bolsters Claim of AIDS Pioneer," Washington Post, 6 October 1990

"AIDS probe shifts to next gear," Chicago Tribune, 7 October 1990, p. 19.

"Gallo Inquiry Takes Puzzling New Turn," Science, 12 October 1990, p. 202.

"Heroes Against AIDS, Sung and Unsung," editorial in the New York Times, 14 October 1990.

"AIDS controversy-Conflicting reports leave readers in a muddle," Media Watch, Chicago Tribune, 31 October 1990. 
precise meaning. However, the ambiguity of his statement impaired the public understanding of what was going on, it impaired the possibility of evaluating the conclusions of the Richards Panel, and it set the stage for divergent interpretations in the press, as in the conflicting headlines of the Washington Post and the New York Times.

A similar criticism can be made of the other paragraph, that "the inquiry team has concluded that Dr. Gallo had a substantial number of HIV detections and isolations from several different sources at the critical time...." What did this conclusion mean or imply? What were the detections and isolations? What were they good for? When? Involved here are also technical aspects of biology. In speaking of "isolations" or "detections," what is meant? To what extent does "isolation" differ from "detection"? A number of concepts arise, among which are:

- the separation of the virus from all other viruses;

- the use of a reagent specific to that particular virus;

- the continuous growth of the virus in fresh cells (called primary culture); and

- the continuous growth of the virus in a cell line, i.e. cells which duplicate themselves indefinitely.

On the basis of Raub's statement, one could not know precisely what the inquiry team concluded. Gallo had blood samples from patients all over the world, and the following questions arose:

Aside from observing transient growth of an uncharacterized virus, what was Gallo's laboratory doing and when? What is the "critical time" referred to by Raub? One possibility was that Gallo's laboratory was able to grow an HIV virus in a cell line at a certain "critical time" only by using the virus stemming from the Pasteur Institute. Did Raub mean by "critical time" the time needed to have priority in making the patent application? How would such a timing affect the patent application and royalties from the patent? In an appendix to this section, I shall reproduce Crewdson's account of the way Raub was issuing misleading statements. We shall also return to these questions in Section V, where we consider the way the OSI and ORI investigations dealt with them.

Finally, Raub gave a list of items which were to be investigated. As stated by Crewdson in his October 6-7 article in the Chicago Tribune: "Not included in Raub's list, however, are several apparent conflicts between Gallo's laboratory records and sworn statements he later made in defending his AIDS test patent from a le- 
gal challenge by Pasteur." In connection with the patent application, the New York Times commented: "The continued investigation casts a shadow over those patent agreements. It is not clear what would happen if the panel found that IIIB was in fact derived from Dr. Montagnier's virus, because the patent used that strain but focused on the method developed by Dr. Popovic to grow the virus continuously in culture." Ultimately, it was determined by a genetic sequencing analysis that HTLV-IIIB is indeed the same as the French virus LAV (so is MOV). However, as of 1993, it was still not clear what will happen to the patent suit.

Subsequent public statements by NIH officials. A year after Raub's press conference of 5 October 1990, a public statement by NIH on 18 October 1991 went beyond by making explicit what had previously been left as an innuendo: “... the OSI has determined and announced previously that since Dr. Gallo had several HIV isolates in his laboratory as well as a continuous culture of a virus not related to the French virus, he had no need to appropriate the virus from the Pasteur Institute."

This public statement is misleading on at least two counts, and is false if one makes more precise certain time periods alluded to in the statement. Indeed:

- Gallo did not have a continuous culture of a virus not related to the French virus in the period October 1983-January 1984.

- The phrase "he had no need to appropriate the virus from the Pasteur Institute" was not announced previously. In Raub's 5 October 1990 statement, it was left as an innuendo. 


\section{APPENDIX \\ From Crewdson's article \\ "Health official reaffirms issues in AIDS lab probe" Chicago Tribune, 28 October 1990, p. 1}

... According to Raub, the decision to investigate the possibility that Gallo had no other "detections and isolations" of the AIDS virus was based not on the Tribune article, which made no such assertion, but on things "that others in the rumor mill of the scientific community have said."

... But Raub told the Tribune that he and the NIH investigative panel "didn't rule out misappropriation," and he cautioned that his statement not be "over read."

"All the group was trying to say," Raub said, "was that it found what it viewed as adequate evidence supporting what is reported" in the second of a series of four landmark papers Gallo published in a single issue of the journal Science in May 1984.

The paper in question reports detections and isolations of the AIDS virus in cells taken from 48 patients, but says nothing about how many of each were made or when they were obtained.

"There were detections and there were isolations," Raub said. "The paper is more careful about that than some of the news reports. To the extent that there are people appropriately concerned about whether there was a deliberate misappropriation, one can't rule out misappropriation. But one can at least say that the obvious motive where nothing else was working, or where nothing was available even, was dealt with."

Raub agreed, however, that saying Gallo had made his own "detections and isolations" of the AIDS virus was "quite different" from saying that such viruses were growing continuously in his laboratory and thus represented an alternative source of virus to the French LAV or his own HTLV-3B with which Gallo could have performed the principal experiments he reported in Science.

In the first of the four Science articles, which investigators have dubbed "Paper A," Gallo claimed he had grown one of his own AIDS viruses continuously for at least five months before the paper was submitted for publication. But the NIH investigators determined, according to Raub's letter to Gallo, that the culture in question apparently had been "repeatedly fed with virus and thus cannot be accurately characterized as 'continuous." 


\section{INTERLUDE: SCIENTIFIC RESPONSIBILITY}

In trying to evaluate the performance of scientists, as individuals or as members of a group, I hope that one standard (among several) would be accepted, namely to ascertain first precisely what responsibility is taken on by the individual or group, toward whom. I shall deal here with a concrete instance of ambiguous responsibilities incurred by some scientists in connection with the Gallo case.

\section{§1. Whatever-It-Is}

Obviously William Raub, Acting Director of NIH, took responsibility for his press release of 5 October 1990 (speaking for NIH), but he also stated: "The consultants nominated by the National Academy of Sciences and the Institute of Medicine will continue to provide oversight and guidance as they did during the enquiry." Thus Raub was invoking the prestige and credibility of other institutions (NAS and IOM) in connection with the NIH "inquiry" or "investigation" of Gallo. As a result, I thought it was important to clarify the role of these people nominated by the NAS and IOM. In order to elicit information, I wrote several letters: to Raub, to James Mason at HHS, to Frank Press, and to Fred Richards, Chairman of Whatever-it-is. None of the answers I received described precisely what was the responsibility of those people.

In a letter dated 13 November 1990, Fred Richards wrote me: "Last spring nine individuals ... were asked to serve as consultants to the National Institutes of Health...." A first ambiguity was: "asked" by whom? Frank Press and the NAS-IOM? HHS? NIH?

Another ambiguity was whether the "consultants" were individuals who would have only individual responsibility, or whether they constituted "the Richards Panel," speaking with a common voice and common responsibility (to whom: NIH? HHS? the scientific community? NAS? IOM?). Various names have been used 
for Whatever-it-is, among which are:

"NIH Investigative Committee" (by Frank Press, in a heading above his list of 11 names);

"advisory panel" (by Frank Press, in a letter to Raub dated 22 February 1990);

"the Committee on which I serve" (by Fred Richards, in a letter to a British scientist Abraham Karpas dated 28 June 1990);

"consultants nominated by the National Academy of Sciences and the Institute of Medicine" (by William Raub, in the press release of 5 October 1990);

"consultants to the National Institutes of Health" (by Fred Richards, in a letter to Lang dated 29 October 1990); and

"nine individuals...consultants to the National Institutes of Health" (by Fred Richards, in a letter to Lang dated 13 November 1990).

This multiplicity of names has had the effect of confusing the community, misleading the community, and rendering ambiguous the responsibilities of those on Whatever-it-is, whether as individuals or collectively as a "panel" or "committee."

\section{Talking to the Press}

In his letter to me of 13 November 1990, Fred Richards did not answer any of my questions, and he wrote me: "At our first meeting we agreed unanimously that all communications with the press or with interested individuals concerning the inquiry or investigation would be handled by the appropriate office of the $\mathrm{Na}$ tional Institutes of Health. I intend to stand by that agreement."

I am not concerned with intent, but I want the community to compare Fred Richards' statement with some facts:

(a) In the Science and Government Report (SGR) of 15 October 1990, Dan Greenberg first mentioned the "literary opacity" of Raub's press release, followed by the resulting conflicting reports in the New York Times and Washington Post, and then he wrote:

In quest of enlightenment, SGR sought the counsel of Frederic M. Richards, Professor of Molecular Physics and Biochemistry at Yale University ... Richards told SGR that his panel had been consulted in the preparation of Raub's announcement and that it approved of its content. But which newspaper was correct? Replied Richards: "If you 
take the average of the Post and Times, you'd probably get it right."

(b) In Science (12 October), Barbara Culliton wrote: "Science has learned [from whom?] that the decision to conduct a formal 'investigation' was pushed on Raub by the Richards Panel. The consultants have maintained from the start that calling the months-long NIH examination an inquiry was a semantic fiction, but Raub resisted an earlier request to designate it an 'investigation'...." She went on:

A Richards Panel member, speaking on a promise of anonymity, said: "There was never any positive evidence of theft. And now, having seen his [Gallo's] records, we know there was no motive. There was no conceivable reason to steal anything."...

(c) Culliton also mentioned a list of 28 specific questions put to Gallo by the NIH Office of Scientific Integrity. She quoted Gallo about his "answers." Then she wrote:

Science asked panel members whether it would be fair to conclude that Gallo's answers to questions about the Science paper were not satisfactory. "Answers? What answers?" asked one panelist. As Science goes to press, it remains unclear just what the panel was told.

(d) In a 28 October 1990 Chicago Tribune article, James Warren wrote:

Talking to members of the scientific panel that handled the just-ended 10-months inquiry, Culliton discovered, "some believe what's left [to be investigated] to be serious, others don't."

Therefore Fred Richards and other members of Whatever-it-is were communicating with the press, agreement or no agreement, "intent" or no "intent." In addition, my letter to Fred Richards of 8 November 1990 started with a reminder of his communication with Dan Greenberg' SGR as per item (a). Consequently I regard Fred Richards' reply of 13 November 1990 as Kafkaesque. In light 
of the history of our relationship, his reply caused me a profound disillusionment.

\section{§3. Evasion of Substantial Issues}

Invoking the "agreement" (which was de facto inoperative at times of people's own choosing) had one effect (among others), to perpetuate the fudging of responsibilities, to withhold information, and to cause only a certain type of information (or disinformation) to make it into the press, while concrete factual questions were stonewalled. In particular, I did not get answers to substantial and specific questions raised in my letters to Fred Richards dated 31 October and 8 November 1990, and my letters to James Mason and William Raub of 31 October 1990. In these letters, I raised three types of questions.

- one type having to do with the meaning of "oversight" and the extent to which Whatever-it-is took responsibility for Raub's statement, whether it took responsibility to leave certain specific items out of the "investigation," etc.

- another type having to do with the merits of the Gallo case: What did he have and when?

- a third type having to do with public statements by the higher-ups.

For example, I object to the ambiguities of the "panel"-approved Raub statement of 5 October 1990, referring to "certain allegations" which were "resolved," without specifying which allegations, who made them, their scientific significance, or how they were resolved. Indeed, Crewdson has been extraordinarily careful in his articles, and he never used the words "theft" or "steal." However, in the context of Crewdson's articles, there was an innuendo in Raub's statement that Crewdson himself made certain allegations, while Raub and his "consultants" managed to evade facing publicly the specific issues raised by Crewdson. I object to the impossibility which I have encountered to have these ambiguities cleared up.

One of the great merits of Crewdson's articles has been their documented, factual, informative content: extensive, specific, and correct. He was factual in his reporting and factual in the way he phrased his analyses and his questions. He deserved to be answered in kind, but I ask the community to compare Crewdson's concrete factual journalism: 
- with Raub's "panel"-approved ambiguous statement which gave rise to conflicting and confused reports in the press;

- with the tendentious and anonymous statements by "panel members" who make statements to the press having journalistic force without taking responsibility for them or being accountable for them, especially the statement about "motive" and "theft"; and

- with Fred Richards' sentence quoted by Dan Greenberg: "If you take the average of the Post and Times, you'd probably get it right." What does this sentence mean? What is its function and effect in the press? As far as I am concerned, this sentence perpetuated loose statements in the press, aside from contradicting Fred Richards' statement of intent to abide by the agreement, namely not to communicate with the press except through the "appropriate office" of the NIH.

I object to a "panel member" giving to the press a statement about a "motive" using the words "to steal" and "theft," engaging the responsibility of the whole "panel" ("we know..."). By issuing such a statement to the press based on such loaded words the anonymous panel member was in contravention of the standards of science which I have taken for granted since I was an undergraduate at Caltech, and which Crewdson himself has followed. A paradoxical situation thus has arisen when a journalist meets certain scientific standards, while some scientists do not. Under the circumstances I ask the community to evaluate the credibility, competence, and standards of Whatever-it-is.

\section{\$4. Accountability and Responsibility}

I have tried to uphold certain standards: check out facts, check out the press reports, ask for more details and specific information, and address those concerned directly. I have met with evasions and stonewalling. Does the scientific community have objections to my raising questions as I did? Will it tolerate such defective responses?

I object to the ambiguous position of responsibility and accountability in which the scientists on Whatever-it-is accepted to place themselves. What are "consultants"? When a business firm hires "consultants," then the responsibility of the consultants is toward the firm, and they are paid for a certain type of professional or technical advice. They represent the interests of the firm. They are accountable to the firm. Were the members of Whatever-it-is such consultants, accountable only to NIH or 
HHS? There is evidence of something else. Frank Press himself emphasized the role which the reputation of the NAS was playing when he accepted to nominate them and when he authorized HHS and NIH to refer to this NAS-IOM nomination. He also engaged the reputation of the NAS-IOM when he wrote "NAS" in front of five names out of eleven on his list of the "NIH Investigative Committee" and "IOM" in front of two names. Raub's press release of 5 October 1990 did make public reference to the NASIOM nomination. Raub used the reputation of the "consultants" and their NAS-IOM pedigree to give public credibility to the NIH investigation when he mentioned their role to "provide oversight and guidance." However, Barbara Culliton's report that some panel members (communicating anonymously with the press) are not even aware of "answers" by Gallo to a list of 28 questions by the Office of Scientific Integrity (see item \$2(c)) raised questions about the trust we could have in the panel's ability to provide "oversight and guidance."

I gave up some time ago on the standards of the higher-ups at $\mathrm{NIH}$, but I had hoped that the scientists on Whatever-it-is at least would be responsible to the community at large, and would meet other standards. We have had a model of higher standards and accountability before. When Feynman was asked to be a member of the Commission investigating the Challenger disaster, he gave us such a model of scientific responsibility. He first got information without problems from the Jet Propulsion Lab at Caltech. He resisted some attempts by William P. Rogers to inhibit his investigation. He interviewed engineers and higher-ups at Morton Thiokol. He was especially interested to explain scientific facts to the public, when he went to the hardware store to get screwdrivers, pliers, and a small C-clamp to do an experiment in front of the video cameras, at a public meeting of the Commission, showing how rubber O-rings lose their elasticity at low temperatures. He wrote a special report, which Al Keel (Executive Officer of the Commission) promised to show everybody, but it turned out at first that neither staff members nor commissioners saw the report. Then, as Feynman writes, "I kept pushing on it, watching it, nursing it along, and finally got it through to the point where it was, at last, in the hands of a real editor, a capable man by the name of Hansen, who changed all my whiches to thats and thats to whiches. Mr. Hansen fixed up my report without changing the sense of it. Then Mr. Keel fixed it up so it could go in as an appendix... ." And ultimately Feynman wrote up his experiences on the Commission in his article "An Outsider's View of the Challenger Inquiry" (Physics Today, February 1988), and in his book 
"What do you care what other people think?." I quote from the article:

One of the ways I was unique was that I was not connected to any organization-I had no weakness from that point of view. I was, of course, connected with Caltech, but that's not a weakness! For example, General Kutyna was in the Air Force, so he couldn't say everything exactly the way he wanted, because he might get in trouble with the Air Force. Sally Ride had a job at NASA. Everyone on the commission had some kind of connection and therefore some kind of weakness, but I was apparently invincible....

Fred Richards accepted being connected with NIH, when he invoked the "agreement" (which he did not always follow). What else is he connected with? He's connected with Yale. Is that a "weakness"? The other 10 members of Whatever-it-is on the list sent to me by Frank Press are connected with Caltech (Harry Gray), U. of Texas (Alfred Gilman), U. Conn (Mary Jane Osborn), Stanford (Stanley Falkow), U. of Texas (Joseph Sambrook), U. of Virginia (Robert Wagner), Princeton (Arnold Levine), Johns Hopkins (John Stobo), Geisinger Clinic (Howard Morgan), and Georgetown University (Judith Areen). Are the connections with these organizations "weaknesses"?

About communicating with the press and the media Feynman wrote:

I did, however, keep talking to the press-openly, always giving my name. I didn't want any hocus-pocus about "unidentified sources," or anything....

Another time, NBC interviewed me-they caught me in the lobby of my hotel. They interviewed me for 15 to 20 minutes - the lady reporter was very short and very niceand I talked in my usual, careful professional way, with all the caveats and so forths and so ons. I saw the interview later on the "Nightly News": I was on for about two seconds-I say something, and BOOM!-it's over. But it was good: The report carried the line of what I said, and the reporter put the context around it, saying things like, "The professor went on to say that this was only the result of a mathematical model and might be uncertain"-stuff like that. It was excellent....

There is also the passage where Feynman relates how he ob- 
jected to some recommendation in the Commission Report. William P. Rogers first told him that he was "outvoted" by the other commissioners. Feynman says "How was I outvoted when there was no meeting?," and Feynman writes about Rogers' reply: "I know, but I called each one of them up," he said, "and they've all agreed. They've all voted for it." But then it turns out that a number of commissioners had not even been contacted by Rogers, and that Feynman was being "railroaded into modifying his report, even though it was going to appear only as an appendix." So he sends a telegram to Rogers:

PLEASE TAKE MY SIGNATURE OFF THE FRONT PAGE OF THE REPORT UNLESS TWO THINGS OCCUR: 1) THERE IS NO TENTH RECOMMENDATION, AND 2) MY REPORT APPEARS AS AN APPENDIX WITHOUT MODIFICATION FROM VERSION \#23 OF MR. HANSEN.

No question here who is taking responsibility for what.

Feynman's model of behavior is far from the model given to us by William Raub-NIH and Fred Richards-Whatever-it-is. Over the last few years, I haven't found many instances of the Feynman model in handling the politics or policing of science, but I have found plenty of instances of another model: evasion, fudging, and obstruction of information, if not outright disinformation. How long is the scientific community going to tolerate such deterioration of scientific standards?

\section{\$5. Techniques of Obfuscation}

In what purported to be a search for an accurate account of events in the Gallo case, the NIH and unfortunately the scientists who accepted to "consult," or "advise," or "investigate," or to provide "oversight" for the NIH, used certain techniques whose effect was obfuscation, not clarification. It may be useful at this point to summarize some of these techniques, documented above:

- describing the same thing with multiple names;

- defining responsibilities ambiguously;

- complicating the structures purportedly looking into the matter; [I list a few: "Inquiry Team," "Office of Scientific Integrity," "advisory panel," "NIH Investigative Committee," "panel of expert scientific advisors drawn from the extramural research community" (from Raub's press release of 5 
October 1990), "investigation team of three outside scientists" (as described in Science, 12 October 1990), etc.]

- issuing ambiguous and opaque public statements to the press;

- leaving out certain documentation;

- putting in vague unattributed allegations;

- refusing to give precise information publicly under the guise of confidentiality, some times;

- giving information (albeit vague, or disinformation) publicly at other times; and

- talking anonymously to the press.

I usually associate such techniques with what some lawyers do, especially when they have a defective case. I am very concerned about what has happened to the standards of scientific behavior when I see scientists using these techniques. 


\section{THE OSI INVESTIGATION}

\section{Conflicting Reactions and "Reining in" Suzanne Hadley}

Conflicting reactions arose in the scientific community, in the midst of an atmosphere of intimidation. Both were summarized, for instance, in the article "Probes widen into troubles at top AIDS lab" by Bonar Menninger (Washington Business Journal, 6 August 1990). This article stated in part:

At stake in the NIH's investigation of Gallo's role in the discovery of HIV is not only the scientist's reputation worldwide, but also by association the reputation and credibility of the entire American AIDS effort as well as hundreds of thousands of dollars in royalties flowing both to the NIH and Gallo from patent rights on the HIV test kits...

One scientist, who declined to be identified, was blunt in his assessment of the latest investigation: "Crewdson basically laid it out, and I think if (the NIH and the National Academy of Sciences) have a shred of integrity, they will have no choice but to find that Gallo misrepresented his work.

"It will be a disgrace for the U.S. and probably quite lucrative for the French, but it will stop the hemorrhaging of integrity."

Not everyone is convinced the case against Gallo is so cut and dried, however. Dr. Michael Hanna Jr., director of Organinon Teknika Corp.'s Rockville-based Biotechnology Research Institute, feels the charges against Gallo primarily reflect the emotional atmosphere surrounding the AIDS epidemic.

"We need to wait until the investigation is complete before making a judgment," Hanna said. "Bob has done an extraordinary amount of outstanding work in science and he 
has made enormous contributions. I'll consider him innocent until proven guilty."

But such sentiments are rare....

"There has to be a higher authority that you answer to. An ethical standard. Bob doesn't play that way. He plays heavy handball, and if you're not on his team, he can make your life miserable," said Dr. Don Francis, a top AIDS administrator with the Center for Disease Control in San Francisco. "He's a very powerful man. It's like a coup in Trinidad. People aren't saying anything until they're sure which side is going to win."

... One of the mysteries often noted is the almost total lack of coverage the stories have received in the popular press, most notably the Washington Post and New York Times.

As of Aug. 21 neither paper of record had reported on last November's Tribune expose, the February NIH investigation the story triggered or the indictment of Salahuddin in late July.

In connection with these last two paragraphs, the issue of press reporting on the Gallo case has been a parallel issue all the way through.

Be that as it may, when Bernadine Healy came in as Director of $\mathrm{NIH}$ in 1991, she "criticized Suzanne Hadley for running a 'satellite office' separate from OSI quarters and operating without direction from her superiors," and she forced the resignation of Suzanne Hadley from the Gallo investigation, as reported for instance in the article "New Questions of Scientific Misconduct Cases Prompt Withdrawal of Health Official" (New York Times, 1 August 1991). Similarly Science (26 July 1991, p. 372) headlined

\section{OSI Investigator "Reined In"}

The Head of the Gallo and Baltimore investigations has been taken off the cases; Bernadine Healy's role in the move prompts congressional hearing

The article started: "Suzanne Hadley, who for several years has supervised NIH's investigations of intramural AIDS researcher Robert Gallo and Tufts immunologist Thereza Imanishi-Kari, has been taken off these two prominent cases. Office of Scientific Integrity (OSI) director Jules Hallum told her early this month to turn in her files from the two investigations. Hallum, while admitting to Science that he told Hadley he'd been ordered to 'rein 
you in,' nevertheless characterizes Hadley's removal from the investigations as a routine and long-expressed personnel transfer. 'That's absurd,' Hadley says. The irony is almost palpable. Hadley, who has spent most of the last 4 years investigating misconduct brought to light by whistleblowers, is now virtually a whistleblower on the office she helped found."

An aid to Dingell at the time was quoted in the Science article as saying: "Everything Hadley has told us has checked out $100 \%$ against documents the committee has received from NIH. She's obviously been treated very shabbily in this thing."

A subsequent article "Can OSI Withstand a Scientific Backlash?" (Science, 6 September 1991, p. 1084) analyzed the situation further:

Yet to the scientific community, the relative disarray of OSI's offices might stand as a metaphor for its operations as a whole. The office is under siege, accused by an array of critics-ranging from Healy to an imposing collection of prominent researchers and scientific societies-of "appalling sloppiness and disregard for the constitutional rights of the scientists it investigates. Indeed, hostility to OSI has grown so overt that Representative John Dingell (D-MI), a frequent critic of NIH misconduct investigations, has come to the office's defense, suggesting that Congress might remove it from the NIH for its own protection.

The stakes in this acrimonious dispute are high-perhaps higher than many OSI critics realize. For behind a parade of familiar charges against the office-it takes too long to complete its investigations, confidential information has leaked to the press on several occasion, it doesn't afford accused scientists full due process-lie deeper questions. Can science satisfy legislators such as Dingell that it is capable of regulating its own conduct? Does an office such as OSI stand any chance of gaining the confidence of the community itself? And if OSI is dismantled or changed beyond recognition at the request of scientists, is the community ready to live with the consequences-a style of investigations more like a criminal proceeding.

Most of the tensions underlying the current debate stem from OSI's attempt to tread a fine line between investigating too hard-thus becoming the much ballyhooed "science police"-and investigating too gently, thereby providing an excuse for Dingell and his colleagues to create a science police force outside NIH. 
... The scientific dialogue model was expected to appeal to scientists, but instead it appears to infuriate them. Hallum argues that it is natural to place the "burden of proof" on the scientist whose data is challenged. Many scientists, however, complain that such procedures amount to little more than "star chamber" proceedings in which subjects are kept ignorant of the evidence against them. To ensure fairness, they argue, OSI must give its targets the kind of protection they would expect in a court of law.

The reporting and analysis by Science (David Hamilton) in the above article fits all other information I have concerning events at that time.

\section{§2. The OSI Report}

A "Draft Report" had been made while Suzanne Hadley was still on board. Subsequently, a report by the OSI in 1992 was first leaked to the press and then issued. Substantial parts of this OSI Report, as quoted in the press, will be reproduced an analyzed in Part I of my response to Gallo's letter below.

The OSI Report did not deal at all with the issue of Gallo's testimony in the patent application for the blood test, and the question whether this testimony included false statements concerning what isolates he had, and which isolates could be grown in cell lines. The OSI Report dealt only partly with the issue of misappropriation of the French virus, and some other related issues. ${ }^{1}$

1 I give two samples, $B$ and $C$, out of a list ranging from $A$ to $I$, as summarized by the subsequent ORI Report, p. 3. I quote from this ORI Report:

B. Misappropriation of HUT78 Cell line. The OSI inquiry and investigation considered whether Dr. Gallo deliberately obscured the origin of the cell line used to grow the HTLV-IIIB culture and failed to give proper credit to Dr. Gazdar, the individual who established the cell line ... the OSI Final Report concluded that there was not sufficient evidence that Dr. Gallo had engaged in scientific misconduct in this matter. However, the OSI Final Report states that Dr. Gallo must share responsibility with Dr. Popovic for "imprecise and non-meticulous science...."

C. Dr. Gallo's role in Barre-Sinoussi 1983 Science paper. The Chicago Tribune article asserted that Dr. Gallo had misrepresented Dr. Montagnier's research in the abstract that Dr. Gallo prepared for a manuscript submitted to Science by Dr. Montagnier's laboratory (F. Barre-Sinoussi et. al., Science 220, 868, 1983). The Chicago Tribune also reported that 
OSI judged that Gallo was not guilty of "misconduct" on any count. The final conclusion of OSI regarding the issue of accidental contamination versus deliberate misappropriation of LAV was that "resolution of this question is not possible based on information available or obtainable by OSI." As summarized by the subsequent ORI Report (December 1992, p. 3), the "Overall Conclusions" of the OSI Report were as follows:

Although the OSI did not make a finding of scientific misconduct against Dr. Gallo based on the issues raised by the Chicago Tribune article, members of the OSI inquiry and investigative teams were concerned throughout the deliberations by the numerous instances in which Dr. Gallo's behavior appeared to be less than collegial and decidedly beneficial to himself and his causes. The OSI cited examples of Dr. Gallo altering the scientific content of published papers purporting to describe data previously presented orally to favor his own purposes, the inclusion of statements in the Barre-Sinoussi paper without the unequivocal agreement of the authors, the misleading statement regarding LAV's growth in a permanent cell line, and inaccurate reporting of the origin of the HT and H9 cell lines. However, the OSI did not find that Dr. Gallo committed scientific misconduct.

NIH Director Healy stated publicly that Gallo was "absolved" by the OSI Report.

\section{3. "Dissent and Critique" by Suzanne Hadley}

Within a short time, Dan Greenberg's Science and Government Report (1 June 1992) published excerpts of a "strong rebuttal" by Suzanne Hadley, stating in part:

The NIH Office of Scientific Integrity (OSI) "Final Report" concerning Dr. Robert Gallo's research on the AIDS virus is a deeply flawed document reflecting an incomplete investigation. The report has been substantially "watered down"

Dr. Gallo added a self-serving sentence to the text of the manuscript that supported Dr. Gallo's hypothesis about the AIDS virus.... The OSI inquiry found that Dr. Gallo had not engaged in scientific misconduct in this matter, but engaged in "gratuitous, self-serving, and improper act." 
from the hard-hitting draft report. Material apparently damaging to Gallo, including some of his own testimony, has been deleted. Specious, unsubstantiated arguments adduced by Gallo and his colleague, Mikulas Popovic, have been accepted unquestioningly by OSI. The OSI even constructed its own arguments exculpatory to Gallo.

A number of the OSI arguments and conclusions cannot be substantiated; a number are flatly refuted by the evidence. Moreover, in a number of instances, OSI has failed to deal with and even mention highly significant pieces of evidence known to be in its possession. Perhaps most serious, the final OSI report gives only superficial, misleading consideration to the implications of the highly significant virus sequencing studies. As a result, the OSI has irresponsibly evaded the central question in the entire investigation, the question of Gallo's possible misappropriation of the Institut Pasteur HIV isolate, LAV.

Dr. Healy's transmittal letter [to Assistant Secretary of Health James O. Mason] for the final report compounds the damage by asserting claims on behalf of Gallo that go well beyond anything in the OSI draft and that, in any event, cannot be substantiated. Most notably, she has asserted that Gallo had other AIDS virus isolates contemporaneous with LAV, with the implication that Gallo had no motive to misappropriate the French virus, and that there is no evidence to support possible misappropriation. These assertions are false....

Among the many significant unaddressed questions are the following:

(1) How did Gallo's virus (HTLV-IIIb) come to be the same as the Institut Pasteur virus, LAV? How could there have been an innocent contamination, given Popovic's statement to Gallo that "the development of [HTLV-IIIb] was almost entirely confined to a room "where no LAV was ever used"?

(2) How did Popovic's "mystery virus," MOV, come to be the same as the Institut Pasteur virus? Was there ever a real MOV virus, or was this merely another name for LAV?

(3) Why was there no sign of any virus in the earliest available sample of HTLV-IIIb?...

Did Gallo have other isolates available to him to establish the cause of AIDS and develop an HIV blood test? In other words, did Gallo have a motive to misappropriate the French virus?

In this connection, it is not adequate to claim in the ab- 
stract, as the OSI leadership and Healy have done, that "Gallo had other isolates." No one questions that Gallo eventually had AIDS virus isolates. But the crucial question with respect to whether Gallo had a motive for misappropriation are: Did he have isolates at the crucial time, i.e. prior to and during the period in which he was growing the French virus, and were any Gallo isolates useful for the crucial early experiments? The OSI has evidence in its possession demonstrating clearly that the answer to these is "no." This certainly does not prove that Gallo misappropriated the French virus, but it clearly shows that he did have a motive for misappropriation. But the OSI did not report this evidence.

To reach the determination in the final report, the OSI altered and deleted (and presumably, ignored) a number of pieces of evidence contained in the draft report....

[There follow a series of specific points which are rather technical and which I omit.]

Finally, there are strong indications that OSI, whether through negligence and/or lack of will, did not identify or pursue several potentially vital issues associated with Gallo/Popovic's experiments with LAV and HTLV-IIIb, and how those experiments were reported in the scientific literature. The evidence concerning these issues is in OSI's possession: it includes evidence that indicates there may have been willful misrepresentations to OSI on the part of some of its witnesses. The question about possible false statements to OSI will be dealt with by appropriate authorities. But OSI's failures have left unexamined the scientific implications of the possible falsehoods.

A month later, on 1 July 1992, Science and Government Report provided some information about the effect of Suzanne Hadley's "dissent and critique" and attempts by NIH to shut her up:

On June 3, following publication of excerpts from Hadley's assessment in SGR [June 1, "Report 'Absolving' Gallo Draws Strong Rebuttal"], Mason's chief for misconduct matters, Lyle W. Bivens, asked Dingell's staff to help him review the NIH report. The request was accompanied by 32 questions derived from Hadley's critique. Bivens heads the Office of Scientific Integrity Review, which advises Mason on misconduct findings.

Clearly infuriated by Hadley, who has been on medical 
leave since March 2, NIH has formally directed her to shut up. In a letter on June 8 from Bonnie R. Kalberer, Acting Director of the NIH office of Science Education Policy, Hadley was told that "you may not make statements to or appear before the media regarding matters relevant to the NIH unless any such activities are cleared in advance by me or my supervisor, Dr. Jay Moskowitz." Healy had previously asked the FBI to investigate Hadley's role in leaks of information from NIH misconduct studies, but the Justice Department declined that assignment as unwarranted.

The NIH gag order specifically referred to statements Hadley reported in Chemical \& Engineering News of May 11 and a report in Science of May 15 stating that Hadley is "now working part time for Representative Dingell...." It also noted that she has appeared on the TV program "Prime Time."

\section{What Did Gallo's Laboratory Have and When}

I shall now address the question what "isolates" were present in Gallo's laboratory and when. Systematically, in Raub's press conference of 5 October 1990 (supported by the Richards Panel), in the OSI Final Report, and in the subsequent ORI Report, it was promulgated that because Gallo's laboratory had many other "isolates" of the so-called AIDS virus, he had no motive to misappropriate the Institut Pasteur's isolate LAV. I shall analyze the merit of this contention, as well as the way the OSI and ORI Reports mentioned or did not mention facts pertaining to this question. I rely on Suzanne Hadley's "Critique" of the OSI Report, as well as her 43-page analysis: "THE ORI 'GALLO' REPORTMisappropriation or Contamination?"

Were the isolates used by Gallo in the cell line for the blood test the ones sent to him by the Institut Pasteur in 1983? The answer is yes, but it is buried in technical terms on page 37 of the OSI Report in the sentence: "By April 1984, HTLV-IIIb cultures contained only the NXB2/LAI sequence (A19-A21A)." The answer to the question could have been expressed in plain, ordinary language, but was not.

One of the ways NIH has systematically given a false impression is by repeated statements to the effect that Gallo had "detections" and "isolates." In this connection, I have already quoted the Raub press conference of 5 October 1990. I shall now quote from the OSI and ORI Reports. 
From the OSI Final Report p. 7. “... the deliberations at the September 1990 meeting of the NIH consultants included the determination that the inquiry had resolved certain of the allegations and issues or shown them to be without substance. Specifically, it was determined that Dr. Gallo had a substantial number of HIV detections and isolations from several different sources at the time HTLV-IIIb and LAV were being grown in his laboratory."

From the ORI Report, p. 16. "By February 22, 1984, the LTCB had accumulated enough information on the isolate $\mathrm{RF}$ such [sic] that it could have been used for development of the AIDS blood test with modest delays relative to the HTLV-IIIB timeline."

From the ORI Report pp. 26-27. "If HTLV-IIIB had been found unsuitable for the blood test, RF could have been used in about three weeks. LS, BK, and possibly other isolates, in about 'three to six weeks, or something like that."'2 The ORI concludes that isolates other than MOV and HTLVIIIB were available in the LTCB that could have been used to develop the blood test on a timeline that would have been only slightly behind that used for the development of the HTLV-IIIB-based test. RF, at least, could have been used with only a minimal delay.

In the first place, the OSI's assertion is objectionable because of its imprecise reference to "the allegations." Whose allegations? (Cf. the Appendix of the preceding section.) I object to the innuendo that Crewdson was responsible for making such vague allegations. If the OSI Final Report did not refer to Crewdson implicitly, then to whom did it refer?

The OSI's assertion to have been meaningful should have specified at least:

- what kind of isolates;

- what these isolates could be used for; and

- at what time did Gallo have these isolates in his laboratory.

What is the meaning of "isolates" and "detections"? Did Gallo

2 The ORI Report here has a footnote, "Popovic 6/26/90 at 78," indicating that it is quoting testimony by Popovic. 
have "isolates" and "detections" in a form which could be useful for the development of the blood test or specifically in a form which could be grown in large quantities, independently of the French virus?

Unless a date is given for the time when Gallo had or did not have "isolates," the so-called "determination" misrepresents what OSI calls "the allegations." Was it in the crucial period October 1983 to January 1984, when Gallo was growing the French "AIDS" virus in a cell line? In this connection, it must be recalled that Gallo did his first Eliza HIV blood test in January 1984, with the French virus. Gallo has asserted that he didn't know the virus he was using was in fact the French virus.

What about other viruses in Gallo's lab? One of Gallo's own isolates was called RF. In the OSI Final Report, we find the following statements concerning RF:

On p. 28: "Isolate RF was a strong contender to be used for the HIV blood test in early 1984. The notes documenting the growth and testing of RF appear complete and generally clear. RF was given special attention by Betsy ReadConnole, who, when she saw the cells dying in December 1983, mixed RF in primary lymphocyte culture with HUT78. The RF/HUT-78 culture rapidly exhibited a strong cytopathic effect, but Ems were negative or equivocal...."

And on p. 29: "In June of 1984, RF was used to infect the H9 cell line, and in the fall of 1984, the infected cell line was transmitted to the Frederick, Maryland, facility for mass production. RF is a notable example of an HIV isolate grown in the LTCB at about the same time as HTLV-IIIB and LAV. It is particularly noteworthy because of its high titer, its pronounced cytopathic effects, and its distinctiveness from HTLV-IIIB. Given these qualities, it is surprising (and from Dr. Gallo's perspective, perhaps regrettable) that $\mathrm{RF}$ was not chosen for use for developing the HIV blood test, especially since it was from a single individual and not a "pool." Dr. Gallo told the inquiry team that the reason HTLV-IIIB was chosen over RF for the blood test was because RF came from a Haitian donor, while the pool was drawn exclusively from domestic donors. A more significant reason for the decision may have been that the pool virus was slightly ahead of RF in its growth and testing history."

I shall analyze point by point how these statements make the 
OSI Final Report untrustworthy.

1. Gallo's explanation why the Haitian donor was not chosen, namely the claim that "the pool was drawn exclusively from domestic donors," is false: The pool had two non-American donors. That OSI in its Final Report reproduced such a purported explanation by Gallo without at the same time recording that Gallo's statement is false misinforms readers and documents the unreliability of this Final Report.

2. In light of testimony to OSI by Gallo and Popovic concerning their own isolates, it should not have been "surprising" to OSI that "RF was not chosen for use for developing the HIV blood test." But in its Final Report, OSI fudges the truth and suppresses evidence. The words "may have been" and "slightly ahead" do not properly represent the situation at the crucial time October 1983 to January 1984. During this period, which may be viewed as the crucial period, whatever isolates or detections Gallo had on his own were not used and could not be used because they were not good enough, for various reasons. One of the reasons was that only the isolate from the Pasteur Institute virus could be grown continuously in a cell line within this period. Some of the testimony by Popovic to that effect was reproduced in the OSI Draft Report of June 1991, but was suppressed in the Final Report. For instance, pp. 45-46 of the 1991 Draft Report, we find the much more explicit statements:

Dr. Popovic said he favored use of the RF isolate because "individual isolates were under more strict control in (a) more organized lab" and because "the origin of it was more clear and under better conditions (12/1/90 interview, transcript pages 109-110). However, RF was somewhat behind IIIB in its culturing and growth; Dr. Popovic said that "in order to be in a good position to go with RF, we needed at least four weeks of work to concentrate on that one and that wasn't done" (22/1/90 interview, transcript page 116). Thus, it appears that when the decision was made to move ahead the submission date for the Science papers, HTLVIIIB became by default the choice to be featured in the Popovic et al. paper.)

Therefore, to state that the reason why RF was not used "may have been" that "the pool virus was slightly ahead..." is a misrepresentation. The pool virus WAS (not "may have been") chosen by Gallo because according to Popovic's testimony, the other isolates were not adequate for Gallo's purposes at the time. 
3. The time-frame June 1984 to fall 1984 mentioned on page 29 of the OSI Final Report is misleading because Gallo wanted to use an isolate for continuous growth in a cell line in the period October 1983 to January 1984, "to move ahead the submission date for the Science papers," and for use in the blood test before June 1984.

The subsequent conclusions from the Office of Research Integrity (ORI) concerning RF were similarly flawed. Suzanne Hadley wrote critiques both of the OSI Report and the ORI Reports. In both critiques she addressed what did Gallo have and when, especially concerning RF. To avoid being repetitive, in the following appendix to this section, I shall quote from her analysis of the ORI Report. Matters are technical, and she has the background to know certain facts.

\section{APPENDIX}

\section{From the analysis by Suzanne Hadley: THE ORI "GALLO" REPORT Misrepresentation or Contamination?} pp. 19-23

It is unclear why ORI chose 22 February 1984 as the cutoff date for its claim about the quality of the LTCB's information on the $\mathrm{RF}$ isolate. In any event, the claim is baseless, for the 'information' on RF the LTCB allegedly had accumulated, as detailed by ORI, is incomplete, unsubstantiated, and incorrect.

Once again, ORI has relied on unsubstantiated claims of LTCB scientists; at the same time, ORI ignores evidence, for which considerable documentation exists, that runs counter to the point ORI apparently is trying to assert.

Specifically:

1. Page 16: "RF was ... transmitted to a permanent cell line ... in mid-December, $1983^{\prime}$ and "... in December 1983, RF induced the giant multi-nucleated cells associated with the cytopathic effect of the AIDS virus." Page 27: "By Christmas 1983, Ms. ReadConnole, a technician, demonstrated that RF could be grown in HUT-78, thereby giving LTCB a cytopathic virus with a documentable origin that could be continuously grown in a permanent cell line."

The fact is that RF was not transmitted to anything in December 1983. Rather, according to Read-Connole's testimony to OSI, HUT-78 cells were mixed with the existing RF culture, around the 
middle of December, when she observed that the culture was "rapidly dying." ORI relied heavily on other aspects of ReadConnole's testimony, but failed to mention her testimony concerning the imminent demise of the culture in December 1983. Likewise, ORI ignores the notation in Read-Connole's laboratory notebook, dated January 10, 1984: "Cells co-cultured after 2 months in culture," i.e., by mid-January. It is clear that by Christmas 1983, all Read-Connole could have known was that the culture was still alive. In other words, there was no evidence, by Christmas 1983, that "continuous growth in a permanent cell line" had been achieved. ORI's claims are contradicted by all the available evidence.

2 . There are no data or notes to support Read-Connole's claim about the presence, in December 1983 of "giant multinucleated cells." Moreover, the existence of "the AIDS virus" had not been demonstrated by December 1983, nor, obviously had the presence of giant multi-nucleated cells been seen to be characteristic of infection with this virus. Thus, even allowing for the possibility that giant multi-nucleated cells were observed in the RF culture in December 1983, it is nonsense to suggest, as ORI does, that Gallo et al. understood this phenomenon to be "associated with the cytopathic effect of the AIDS virus."

3. ORI claims that "RF was RT positive." There are no primary data to substantiate this claim. In fact, as noted in the Critique of the OSI Final Report: "Inexplicably, RT assays reportedly were not done for at least the first two-to-three months of RF culturing." Read-Connole's notes, dated January 10, 1984, state concerning RF: "Initial cultures negative for p19, RT and EM." Gallo himself, in his response to OSI's queries on the May 1984 Popovic et al. Science paper, confirmed that early RTs on RF were not done: "Assays for reverse transcriptase activity in the supernatants of early cultures of RF were not done." When queried further about this matter, Gallo attributed the absence of RT data on RF to "an enormous backlog of RT samples to be run in Dr. Sarin's laboratory during the period of the RF cultures." Yet according to Dr. Popovic and Ms. Read-Connole, by the time RF was in culture, it was Dr. Sarngardharan, not Dr. Sarin, who was performing RT assays for the LTCB, because Dr. Sarin's assays had earlier proven to be seriously unreliable.

4. ORI says that "IFA's [sic] indicated that rabbit antiserum and AUDS patient serum reacted with RF infected cells." In making this claim, ORI fails to state that prior to the end of February, the IFA data on RF were, at best, marginal. ORI fails to cite the data in Read-Connole's notebooks and summarized in the critique of 
the OSI Final Report, data that by Read-Connole's own account, showed the RF IFA positive reading was only minimal.

(b) ORI fails to give any attention whatsoever to the paradoxical, persistingly negative EM data on RF. By Popovic's own account (November 28, 1984 Popovic-to-Gallo memorandum titled "Documentation of Chronological Detection and Isolation of HTLV-III RF"), the lack of EM evidence" for RF was the reason that Popovic chose to use the "pool" isolate rather than RF for the LTCB's HIV blood test. Popovic's memorandum actually details a number of reasons why RF was not chosen, was not even a viable candidate for the blood test (see below), but the fact is that as late as October 1984, Gallo et al. had no positive EM data on RF; yet in the Popovic et al. May 1984 Science paper, RF was reported as EM positive.

Elsewhere in its report, ORI notes "that the National Academy of Sciences consultants to NIH (the "Richards Committee") criticized Gallo for having unilaterally decided, over the expert opinion of the electron microscopist, that RF was EM positive. But the Richards Committee critique on this point is not mentioned in ORI's recitation of the evidence that it apparently believes supports the viability of $R F$ as a candidate for a blood test, pointing once again to the curious lack of coherence of the ORI Report, not to mention ORI's convenient propensity for ignoring evidence that runs contrary to its themes.

(c) Such information as was available on RF throughout the Spring and Summer of 1984 indicates clearly that RF was at all times significantly behind the "pool" virus, as well as MOV and LAV, as a potential candidate for an AIDS blood test. Besides the numerous significant negative, nonexistent, and marginal readings on RF, as cited above, it also is the case that:

1. RF was not put in the LTCB's "best grower" clone, H9, until June 1984;

2. Prior to this time, Gallo et al. had no idea how well-or even if- $\mathrm{RF}$ was capable of producing large quantities of high titre virus. $\mathrm{RF}$ was not sent for large-scale production (an intermediate step preliminary to "mass," commercial-level production) until, reportedly, "around the end of November 1984." (Actually, this date is questionable; probably it is too early, for Popovic's November 28 memorandum notes that "At the present time we are intensively pursuing the single-cell cloning and superinfection of H9 cells and other target cells to achieve $80 \%$ to $90 \%$ positivity for HTLV-IIIRF," which step, Popovic says, "should be accomplished within a few weeks."

As late as April 1985, RF was available only in cases of "urgent 
need," due to the presence of mycoplama in the large-scale production cultures. According to Electro-Nucleonics, Inc., the laboratory in charge of RF's large-scale production, as of April 1985, the laboratory did not expect "to have a mycoplama-free culture" for several months. Thus, even this late, $\mathrm{RF}$ was useable for very little indeed.

3. RF was never used as the antigen in an AIDS virus antibody blood test, an absolutely essential step in selecting an isolate for the test. Gallo et al. had no idea whether RF would be useful for reliably and discriminably identifying antibodies to the AIDS virus.

For RF to have been a viable competitor to IIIB for use in the LTCB blood test, all the above steps would have had to be successfully accomplished. It would have required a minimum of several weeks to even attempt these experiments; even then, there was no guarantee that they would succeed in a timely fashion. In fact, the available evidence strongly indicates the contrary. ORI's claim that "RF could have been used for development of the AIKDS blood test"-like the comparable claims of Gallo et al. is speculative and entirely unsubstantiated.

(d) Newly discovered evidence indicates that at least the initial culture of RF was not a satisfactory grower. Specifically, in July 1985, at a meeting of the NCI Vaccine Development Group, there was discussion of the problematic growth of "RFI," which had been sent to the Fredrick facility, presumably for mass production for work on an AIDS vaccine. Minutes of the July 1985 meeting show that the participants who included Dr. Popovic, agreed that RFI should be replaced with "RFII," not otherwise described except as being available from Dr. Popovic.

The evidence showing that "RFI" was a less than optimal grower bears out the testimony to OSI of Dr. Larry Arthur, chief of the laboratory at the Frederick Cancer Research Center that mass produced virus for Gallo. According to Arthur, RF, which he received "well after" he first received the "pool" virus, "was a lower producer than the IIIb in our hands" $(1 / 28 / 91$ interview; annotated transcript pages 19-20).

In short, the totality of the evidence concerning $R F$ flatly refutes ORI's (and Gallo's) contention that RF could have been used for the LTCB's HIV blood test. ORI's treatment of the issue is inaccurate and incomplete; its conclusions cannot be substantiated. 


\section{ABUSE OF THE RICHARDS PANEL BY NIH}

We now return to the role of the Richards Panel in the OSI Report. I have a number of criticisms involving this panel:

- The panel did not "oversee" the investigation, and did not do the necessary gumshoe work to find out about material which $\mathrm{NIH}$ withheld from its considerations.

- The panel accepted to work under conditions of "confidentiality." A "Confidentiality Agreement" which these members accepted to sign is reproduced in full as an illustration in the next part.

- The panel was abused by NIH, and especially by NIH Director Bernadine Healy, who undermined the integrity of scientific consultation.

Healy obtained the panel's views by asking the members to return a questionnaire concerning the investigation. The first question was: "Does the report show that the investigative process was thorough and pursued the issues appropriately?" This question fits under the first item which I criticize above. The panel's answer was: "We believe that the collection of physical evidence, the investigation of the facts, and the interviews of the witnesses were thorough and appropriate. However, we believe that certain of the analyses and conclusions of these investigations are flawed. The problems are discussed below." Of course, I have no direct information about the collection of physical evidence, the investigation of the facts, and the interviews of witnesses. But the critique by Suzanne Hadley of the "draft report" gives indications that all three were insufficient and that documentation available to NIH was withheld from the Richards Panel. Short of contacting Suzanne Hadley herself or outside sources such as the Dingell Committee, there was no way the panel could know what material was withheld from its considerations.

In answer to a second question by Healy: "Are the issues/ allegations stated properly in the proposed final report?," the 
panel answered: "Yes. This aspect of the Report represents a very good job." However, Crewdson's documentation concerning possibly false statements by Gallo in his patent application was not dealt with in the OSI Report. Nevertheless, the panel answered "yes" to the third question whether "the proposed final report addressed all the issues that should be addressed."

On the other hand, the panel answered "no" to the question whether "all of the issues were appropriately covered." It stated: "Each of the allegations raised against the Popovic et al. paper is considered independently in the Report and in no obvious or stated order of priority. This tends to trivialize the significance of the findings. The Conclusion section castigates the overall level of accuracy of the paper, but fails to integrate the findings into a larger context, namely a pattern of behavior on Dr. Gallo's part that repeatedly misrepresents, suppresses and distorts data and their interpretation in such a way as to enhance Dr. Gallo's claim to priority and primacy." The panel then went on to detail a list of events which document such a pattern. I cite one of them to give the scientific flavor of the Richards Panel answer:

A. LAV (LAI) was grown successfully in the Gallo laboratory during the fall of 1983. In particular, LAV was successfully propagated using HUT78 cells. Thus, a crucial fact was established-HUT78 cells were permissive for the growth of LAV (i.e. the causative agent of AIDS). The Gallo lab "went to school" with the French virus, yet they later failed to mention the fact that they had propagated the French virus. In fact, they denied propagation of the French virus and stated (in the Popovic et al. manuscript) that the French virus had never been transmitted to a permanent cell line. Given the quality of the information derived from propagation of the French virus, we believe that this constitutes intellectual recklessness of a high degree-in essence, intellectual appropriation of the French viral isolate.

The conclusions of "intellectual recklessness of a high degree" and "intellectual appropriation" are remarkable. This was the first time any "official" body said any such thing.

I was especially concerned with the role played by the National Academy of Sciences. After its top officials nominated the panel, they subsequently evaded the responsibility to insure the integrity of scientific consultation, as illustrated in the following exchange of letters. I first wrote to the Council of the Academy on 5 April 1992, concerning Gallo's election in 1988. 


\section{My Letter to the NAS Council}

To the Council

National Academy of Sciences

2101 Constitution Ave

Washington, DC 20418

Robert Gallo was elected to the National Academy of Sciences in 1988. John Crewdson's book-length article in the Chicago Tribune of 19 November 1989 started nationally a long train of questioning of scientific practices by Gallo. Following a request by $\mathrm{NIH}$, the Academy "developed a list of nominees to oversee the review by the National Institutes of Health of the circumstances leading to the discovery of the AIDS virus and the allegations about the research practices of Dr. Robert Gallo." [Letter from Frank Press to James Mason, Assistant Secretary of Health, 13 March 1990.] The panel thus nominated by the Academy was chaired by Fred Richards.

The latest article by Crewdson in the Chicago Tribune of 27 March 1992 quotes extensively from a report by the Richards Panel to NIH. I reproduce here some paragraphs from Crewdson's article:

In her charge to the panel members, Healy asked for their opinion on whether the NIH report represented "an appropriate, thorough, and credible investigation of the charges" against Gallo.

In several important respects, the panel said, it did not.

The NIH report is not uncritical of Gallo whom it accuses of "an unhealthy disregard for accepted standards of professional and scientific ethics." The panel, however, faults the NIH for failing to present its findings in a "larger context."

To have done so, it says, would have demonstrated "a pattern of behavior on Dr. Gallo's part that repeatedly misrepresents, suppresses, and distorts data and their interpretation in such a way as to enhance Dr. Gallo's claim to priority."

... Popovic told NIH investigators that his initial draft of the 1984 article included the acknowledgement that he had grown and performed experiments with the French virus, and had used it as a "reference virus" in later experiments.

But Popovic said that, despite his insistence on giving credit to the French, Gallo deleted his acknowledgments 
from the manuscript with the written comments: "Mika, are you crazy?" and "Mika, you are incredible." Popovic is known to friends as Mika.

... The published Science article declared that the French virus "has not yet been transmitted to a permanently growing cell line for true isolation"-precisely the experiment, the NIH investigation found, that Popovic had performed successfully several months before.

The NIH report nevertheless accepted Gallo's claim that he had not intended to conceal his work with the French virus. The questioned statement, he said, had referred not to work in his own laboratory but to what he then believed was the inability of the Pasteur scientists to grow their own virus.

According to the panel, however, Gallo's statement was indicative of "a pattern of misrepresentation" in the description of the isolation of the AIDS virus in the Science article.

"The statement," the panel wrote, "was simply false and was known to be false at the time the paper was written" and represented "one of the most glaring faults in the paper." The panel concluded that "there is no way in which Dr. Gallo can be excused from sharing the blame for this misstatement."

Not only did Gallo's failure to acknowledge his work with the French virus represent "intellectual recklessness of a high degree," the panel said, it amounted to the "intellectual appropriation of the French viral isolate."...

Gallo's nomination and support for election to the NAS in 1988 was based in large part on his purported contributions to discoveries concerning the AIDS virus. The information that has since come out publicly (but there are indications that it was previously known to some researchers in his field) strongly indicates that Gallo was nominated and elected to the Academy under a questionable representation of his work.

Therefore, both as a member of the NAS and a member of the scientific community at large, I ask the Council to start a public investigation of the merits of Gallo's nomination and election, because the National Academy of Sciences is responsible and accountable to the scientific community at large for its standards, as well as for promoting standards and setting examples of standards. Membership in the NAS is taken seriously by some people, who see it as bestowing scientific credibility and certifying scien- 
tific achievement. I am aware that the bylaws of the Academy do not have provisions for the resignation of someone from the Academy. But the question whether anyone-Gallo in the present instance-is to resign from the Academy is not the only question that needs to be addressed, nor in my opinion is it such an important one. The Academy could very well clear itself by admitting publicly to having been misled (it remains to be determined by whom and how), without taking the statutory step of forcing Gallo's resignation.

Sincerely yours, Serge Lang

cc: John Crewdson, Robert Gallo, Fred Richards, Edward DavidCOSEPUP Panel, Gérard Debreu (Chair, Social Science Class of the NAS), etc.

Enclosure: Crewdson's article of 27 March 1992.

In a PS to this letter, I recalled the open letter by John Cairns to an officer of the NAS, published in Nature (11 July 1991, p. 101). Excerpts from this letter are reproduced in the chapter on the Baltimore case, which was the original context of the letter. Here in the context of the Gallo case, I reminded the Council that I wrote to the Council on 25 February 1990 objecting to Gallo's election even at that time. I deplored how "the natural tendency of the higher-ups in the NAS has been toward secrecy, looking the other way, taking the limited hang-out route, refusing internal, let alone public discussion about certain issues.... The Council of the Academy and the Academy itself, have to make a choice as to the leadership they will provide. The history of the past two years shows that the Academy's failure of responsibility is continuing exactly as I described it in 1990."

\section{Other NAS-Related Correspondence}

I received a terse reply dated 8 May 1992, from the NAS Home Secretary Peter Raven. He informed me that the Council discussed my letter concerning Gallo, and asserted: "The Academy will not 'undertake a public investigation of the merits of Gallo's nomination and election' as you requested."

A month later, on 4 May 1992, I wrote directly to Frank Press, President of the NAS: 
Dear Dr. Press,

1. On 15 February 1990, the HHS Assistant Secretary James Mason wrote you:

As you know, an article published this past November in the Chicago Tribune made a number of allegations about the research practices of Dr. Robert Gallo.... In accordance with its normal procedures, the NIH now is engaged in an inquiry to determine what, if any, significance the charges might have.... With a view to insuring both the fact and appearance of objectivity for the inquiry [sic], Dr. William Raub, the Acting Director, NIH, has asked me to solicit the assistance of the National Academy of Sciences (NAS) in nominating candidates for a special advisory panel ... to make informed, unbiased judgments [sic] about the issues raised in the Chicago Tribune article.

You agreed to cooperate with NIH and HHS in this matter, and accordingly you wrote to James Mason on 13 March 1990 to nominate the members of such a panel,

to oversee the review by the National Institutes of Health of the circumstances leading to the discovery of the AIDS virus and the allegations about the research practices of Dr. Robert Gallo.

In his press conference of 5 October 1990, NIH Acting Director William Raub made use of the prestige of the NAS by stating: "The consultants nominated by the National Academy of Sciences and the Institute of Medicine will continue to provide oversight and guidance as they did during the inquiry." 1

Now, two years later, as reported by Crewdson in the Chicago Tribune of 27 March 1992, we learned that the Richards Panel had indeed issued its judgment of the NIH inquiry and of Gallo's practices, and that this judgment was unfavorable. As quoted by Crewdson, the Richards Panel blamed the NIH report for not presenting its findings "in a larger context" which would show "a pattern of behavior on Dr. Gallo's part that repeatedly misrepre-

1 Incidentally, I was very critical at the time of what was said at this press conference and the way the Richards panel approved what was said, but this is another issue. 
sents, suppresses, and distorts data and their interpretation in such a way as to enhance Dr. Gallo's claim to priority ... intellectual recklessness of a high degree ... intellectual appropriation of the French viral isolate...."

However, NIH and HHS decided not to accept the judgment of the Richards Panel. In an article headlined "NIH Vindicates Researcher Gallo in AIDS Virus Dispute" (Washington Post 26 April 1992), Malcolm Gladwell wrote: "In making her decision to approve the Gallo report without major changes, [NIH Director] Healy considered-but ultimately did not accept-the advice of a panel of outside consultants who said the report was too mild in its criticisms of Gallo." Gladwell also casts aspersions on the judgments of the Richards Panel. Thus NIH and HHS throw down the gauntlet via the press. At the same time neither the NIH Gallo Report nor the Richards Panel Report have been made officially public even though they are available to some reporters!

The current scenario involving the NAS, NIH, HHS, and the Fred Richards Panel is worthy of Kafka and Ionesco.

2. NIH and HHS have been less concerned with the integrity of science than with leaks of the NIH investigation, leaks of the Richards Panel report, covering up and muzzling scientists. Indeed:

(a) Dan Greenberg's Science and Government Report of 1 April 1992 states:

Despite Healy's campaign against leaks from OSI, the place still leaks, often to the Chicago Tribune, whose Pulitzer Prize reporter John Crewdson has led the journalistic field in coverage of the long-running controversy concerning Robert Gallo's role in the identification of the AIDS virus. All this despite changing OSI's locks, engagement of a security officer, and other anti-leak steps.

Apparently obsessed by the leaks, Healy unsuccessfully tried to enlist the gumshoe services of the Inspector General of the Department of Health and Human Services. IGs, however, are not always hostile to leakers.

Healy then turned to the FBI, writing on March 10 to an agent in the FBI's Silver Spring, Md., office an emotionally souped-up letter prophesying the demise of NIH and government supported biomedical and behavioral research if the leaks are not sealed....

Healy's appeal to the FBI was likewise mentioned in Crewdson's article of 27 March 1992 and in Science (Official Doubt on the 
AIDS Test Patent, 3 April 1992), both quoting Healy's letter to the FBI agent, to the effect that the leaks have

demonstrably damaged the credibility of the U.S. government's position on patent and other related business matters ... [the damage caused by the leaks was] substantial and likely in the millions of dollars.

(b) Another Science article (The Richards Panel Tosses a Curve, 3 April 1992) states:

Members of the panel contacted by Science declined to discuss their report, privately expressing their frustration with a confidentiality agreement they were forced to sign by NIH.

Thus we find scientific and intellectual corruption against a backdrop of financial concerns at the highest levels of the science establishment. As far as I am concerned, the NIH and HHS have discredited themselves by their cover up and their muzzling of the panel nominated by the NAS.

Thus we also find scientists accepting to "oversee" under conditions of confidentiality instead of refusing to do so because of their responsibility and accountability to the scientific community at large. Since the NAS was solicited publicly by NIH to oversee the Gallo investigation, and the NAS accepted publicly, the NAS and the Richards Panel are now accessories after the fact unless they act publicly to the contrary. Unless the NAS and the members of the Richards Panel publicly object to the way they were used and abused by NIH, they will also discredit themselves.

3. The breach of trust by NIH-HHS vis-à-vis the NAS, the tacit acceptance of this state of affairs (so far) by the NAS and the Richards Panel, and the behavior of NIH-HHS toward those scientists who try to bring truth to the public, constitute a profound breakdown in the standards and credibility of the scientific establishment. As a scientist, as a member of the NAS, as a member of the academic community, and as a citizen, I wish to record here my unmitigated disgust.

\section{Serge Lang}

cc: Fred Richards, John Crewdson, Dan Greenberg, John Dingell, etc. 
Frank Press replied officially in his capacity as NAS President, on 7 May 1992: "I have your letter in which you register unmitigated disgust with the Gallo investigation and the role of NIH-HHS and the NAS. It was clear to both the NIH and to the Academy that our role in the matter was to provide to NSF [sic] names of reputable scientists qualified to serve in an advisory role. Regardless of what individuals have stated publicly, it was clear to NIH and to the Academy that this was to be an exclusively NIH committee with no further role for the Academy than to suggest names. We have served in the role of identifying experts on numerous occasions for many organizations, both public and private."

I wrote back on 14 May 1992: "This is to acknowledge receipt of your letter of 7 May 1992, which to me is verbiage. I do not understand the relevance of your phrases starting with it was clear..., and I wonder about their role in your letter. There is an innuendo in those sentences that somehow I am not representing the situation properly in my own letter. However, what 'was clear' to whoever is irrelevant, and I object being put in a position of having to consider what "was clear to both the NIH and to the Academy.' I commented on the record as it exists, not as people might rewrite it. In my letter to you I quoted correctly and in context from the exchange you had with James Mason, and I quoted correctly and in context from Raub's press conference. I therefore stuck to the record and I ask others to evaluate those concerned on the basis of this record. I hold people involved in this record responsible and accountable for their actions. I stand by what I wrote."

These exchanges document the way top officials of the NAS evaded taking responsibility for supporting the panel which they had nominated.

Opinions in the Academy are of course not monolithic, and I have no idea how many people share my viewpoint. Some members of the NAS wrote in support of the point of view expressed in some of my mailings, e.g. Jack Steinberger wrote to me to express "100\% support", and Philip Siekevitz wrote to Frank Press (9 September 1992): “... the members of the committee selected by the NAS and the IOM were used by the NIH, indeed were misused. In your correspondence with Dr. James Mason, you point out that the group selected was not an 'NAS group' and should not be identified as such. However, I do not think you can get the NAS off the hook completely. Since the NAS did the selection, it should back up the members of the group, it should not dismiss its responsibility to the members of the group in its battle with the NIH. I think that an honorable duty would be that the NAS 
castigates publicly, how its members were treated, demand an apology from the NIH for its dismissal of the findings of the members selected by the NAS re the "Gallo Affair."

For one member of the Academy who does not agree, I mention Freeman Dyson. In his article "Science in Trouble" (American Scholar, 62, 1993, pp. 513-525), he wrote:

The personal behavior of scientists is taken very seriously by our official guardians, the National Academy of Sciences and the departments of government concerned with the funding of science. At a meeting of scientists at Princeton some years ago, various functionaries from the Washington office of the National Academy of Sciences spoke. One of them talked like a Grand Inquisitor. She said her mission was to stamp our Deviant Science. I disagreed sharply with her. I do not find it shocking that some of our best scientists turn out to be cheats or crooks. Creative people in any walk of life have a tendency to be odd. To stamp out Deviant Science means to drive out odd people from our profession. Scientists should be subject to the same laws as other citizens so far as criminal behavior is concerned. It is a fundamental mistake to pretend that scientists are more virtuous than other people or to attempt the enforcement of virtue by means of an Academy inquisition.

I was recently invited by the Academy to serve on a committee to investigate the alleged violation of ethical standards by the biologist Robert Gallo. The president of the Academy informed me that service on the committee was an important public duty. Nevertheless, I declined. I did not wish to be a part of any such inquisition. Robert Gallo is a scientific entrepreneur who has made enormous contributions to the understanding of the AIDS virus. The position of Robert Gallo in the world of biology is like the position that Robert Oppenheimer occupied forty years ago in the world of physics. The two Roberts were both successful scientific empire builders. They both ran big organizations with brilliant flair and with some disregard for bureaucratic rules. They were both accused of deviousness and occasional dishonesty.... The proceedings against Gallo have the same vindictive character as the proceedings against Oppenheimer. Our National Academy of Sciences is now lending its name to such proceedings in the same way as the Atomic Energy Commission did in 1954. In both cases, a great man is being harassed and punished for offenses that 
are, in comparison with his achievements and his services to society, trivial.

I am amazed by Dyson's statements on several counts. First, the Home Secretary had categorically written to me that the Academy would not undertake a "public investigation" of the merits of Gallo's election, as I requested. Two letters from me to Dyson asking for more information about the NAS Committee remained unanswered. My experience with the NAS was the opposite of Dyson's: publicly, the Academy totally kept from taking any responsibility in the Gallo case, as documented above. Upon checking with a staff member of the Academy, I was told that Dyson's reference, as far as this staff member knew, was to the Richards Panel, and that Dyson gave a misleading impression with his sentence: "I was recently invited by the Academy to serve on a committee to investigate the alleged violation of ethical standards by the biologist Robert Gallo." Nevertheless, I don't know of any public, on the record correction to the Dyson article, either by him or by the Academy.

Second, I find Dyson's comparison between the Gallo and Oppenheimer cases to be flabbergasting from a historical point of view. Both cases are sufficiently famous so that I will leave to others their evaluation of Dyson's comparison, without any further comment here. I merely want to mention one important case of a famous member of the NAS who holds opinions quite divergent from mine. 


\section{THE INTEGRITY OF SCIENTIFIC CONSULTATION}

I thought the responsibility of the NAS was to play an active role in maintaining the integrity of scientific consultation to the government. Having failed to arouse the interest of top officials of the NAS, I contacted the Section Chairs by writing to them directly. I never received an answer from any of them to the following letter dated 1 September 1992. The letter was accompanied by 40 pages of enclosures, giving primary sources for my assertions, and listed at the end of the letter.

\section{To all Section Chairs National Academy of Sciences}

NIH investigated the Gallo case as a result of John Crewdson's major journalistic contribution in the Chicago Tribune of November 1989. NIH and HHS involved the NAS by soliciting the nomination of a panel of independent consultants to enhance the credibility of the investigation. However, NIH and HHS subsequently betrayed their commitment to the panel and to the NAS. I shall therefore deal here with a major issue, which arose in the Gallo case, but transcends the Gallo case, namely:

The integrity of scientific consultation for the government is at stake, ${ }^{1}$ especially concerning the involvement of the

${ }^{1}$ Also at stake is the integrity and credibility of NIH and HHS. There is evidence that NIH misrepresented certain facts and suppressed evidence unfavorable to Gallo, both in the Final Report from its Office of Scientific Integrity (OSI) and in the cover letter by NIH Director Bernadine Healy forwarding the report to James Mason. The article on the OSI Final Report in Chemical and Engineering News (11 May 1992) gave some evidence to this effect, and was accompanied by a boxed boldfaced editorial comment: "Report raises questions as to whether NIH, HHS can objectively investigate prominent scientists." (Copy enclosed.)

Dan Greenberg in Science and Government Report, 1 June 1992, quotes excerpts from a "dissent and critique" prepared for the Dingell Committee (copy enclosed). Some conclusions from these excerpts state: "The Office of Scientific Integrity (OSI) 'Final Report' concerning Dr. Robert Gallo's research on the AIDS virus is a deeply flawed document reflecting 


\section{National Academy of Sciences.}

I am addressing this mailing to you for direct action on your part at the grass roots.

Responsibility of the NAS via HHS and NIH. On 15 February 1990, HHS Assistant Secretary James Mason wrote to Frank Press (President of the National Academy of Sciences): "With a view to insuring both the fact and appearance of objectivity by the inquiry, Dr. William Raub, the Acting Director, NIH, has asked me to solicit the assistance of the National Academy of Sciences (NAS) in nominating candidates for a special advisory panel ... to make informed, unbiased judgments about the issues raised in the Chicago Tribune article." Frank Press and Samuel O. Thier (President of the NAS Institute of Medicine) agreed to nominate the members of such a panel "to oversee the review by the $\mathrm{Na}$ tional Institutes of Health of the circumstances leading to the discovery of the AIDS virus and the allegations about the research practices of Dr. Robert Gallo."

Betrayal of commitment to the NAS. The subsequent history shows that HHS and NIH betrayed their commitment to the NAS (and to the scientific community at large) in several ways, among which:

- NIH extracted a "Confidentiality Agreement" from the members of the Richards Panel, thus muzzling these consultants.

- NIH operated in such a way that the Richards Panel could not "oversee" the investigation, as specified by Frank Press and Samuel O. Thier.

- NIH withheld information from the OSI Report on which the Richards Panel was asked to comment.

an incomplete investigation.... A number of the OSI arguments and conclusions cannot be substantiated; a number are flatly refuted by the evidence. Moreover, in a number of instances, OSI has failed to deal with and even mention highly significant pieces of evidence known to be in its possession. Perhaps most serious, the final OSI Report gives only superficial, misleading consideration to the implications of the highly significant virus sequencing studies. As a result, the OSI has irresponsibly evaded the central question in the entire investigation, the question of Gallo's possible misappropriation of the Institut Pasteur HIV isolate, LAV...."

However, in the present letter I concentrate on the issue of respective responsibilities between the NAS, NIH-HHS, and the Richards Panel nominated by the NAS to "oversee" the NIH investigation. 
- NIH Director Healy used other consultants of her own choosing to override the Richards Panel.

- NIH Director Healy undermined the Richards Panel in the press.

- NIH Director Healy distorted and improperly represented the views and reports of the Richards Panel members.

In an appendix, I shall provide detailed documentation on these items, showing how seriously the integrity of scientific consultation was compromised. However, I mention one aspect of the Confidentiality Agreement here because it involves the NAS specifically. The Agreement concludes with the sentence:

I understand that in the event an investigation establishes a failure on my part to comply with the terms of this agreement, NIH may pursue such actions as are legally available to them, including, but not limited to, taking such failure into account in making future hiring or appointment decisions, and reporting such failure to the National Academy of Sciences.

The invocation of the NAS in this Confidentiality Agreement ("reporting such failure to the National Academy of Sciences") makes the NAS an accessory to the fact by implication. It is now incumbent on the NAS either to take direct responsibility for the Confidentiality Agreement or to repudiate this Agreement and the way the NAS was invoked in this Agreement. 


\section{CONFIDENTIALITY AGREEMENT}

I understand that the Office of Scientific Integrity's (OSI) proposed final report of the investigation into possible misconduct by Dr. Gallo and Dr. Popovic is being made available to me for the limited purpose of review and consent so that I may provide individual advice to the OSI and the National Institutes of Health (NIH).

I agree, as a condition of my consulting relationship with the $\mathrm{NIH}$, to observe strict confidentiality with respect to the proposed final report, the information contained in it, and all information I obtain as a result of any meetings to discuss the proposed final report. Specifically, I agree to the following conditions to ensure such confidentiality: (1) While the proposed final report is in my possession, I will not disclose it to anyone and will safeguard it so that it will not be inadvertently disclosed to anyone; (2) I will not make any copies of the proposed final report; and at the conclusion of the review session for which a copy of the proposed final report has been made available to me, I will immediately return to the NIH the copy of the draft report made available to me and all notes or other written documents that I have made that refer to the proposed final report or any discussion of it; (3) I will not talk to anyone, other than authorized representatives of the OSI and $\mathrm{NIH}$, about the proposed final report or the review session; (4) If I am contacted by a representative of the news media, I will immediately refer that individual to the $\mathrm{NIH}$ Office of Communications without disclosing or acknowledging any information about the proposed final report or the review session; and (5) I will cooperate fully with any government investigation of any unauthorized disclosure of the proposed final report. Notwithstanding the preceding sentences in this paragraph nothing contained herein shall bind the signer to refrain from commenting on the final report of this investigation, if and when it is publicly released in an authorized manner.

I understand that in the event an investigation establishes a failure on my part to comply with the terms of this agreement, NIH may pursue such actions as are legally available to it, including, but not limited to taking such failure into account in making future hiring or appointment decisions and reporting such failure to the National Academy of Sciences.

DATED:

SIGNED:

The Confidentiality Agreement above was signed on 30 January 1992 by six members of the panel: Judith Areen, Alfred Gilman, Mary J. Osborn, Fred Richards, John Stobo, and Robert R. Wagner. 
I hope that you and the scientific community will go along with the model provided for us by Feynman when he was on the Challenger Commission. At all times Feynman preserved and used his prerogative to inform and analyze publicly. ${ }^{2}$ I am also appealing to the Dingell Committee to help the scientific community in having this Confidentiality Agreement abrogated.

Conclusions. Integrity of scientific consultation destroyed. On the basis of the documentation I am providing for you, I conclude that far from using the NAS to provide an independent panel to "oversee" its investigation, "with a view to insuring both the fact and appearance of objectivity by the inquiry," NIH-HHS are insuring both the fact and appearance of a cover-up. Indeed, NIH-HHS have shown that if such a panel comes to conclusions opposed to the views of the NIH Director, then this Director manipulates the panel, muzzles the panel, treats that panel improperly, undermines the panel in the press, disregards its views, misrepresents its views, and selects other advisers who can be relied on to reflect the views of the NIH Director. Thus the NIH Director, and HHS, which has the ultimate responsibility, destroy the integrity of scientific consultation, which involved the NAS.

Future scientific consultation compromised. Various publications have reported the disenchantment of the members of the Richards Panel, and their wariness of consulting for the government in the future because of the way they have been treated by NIH-HHS. Science (8 May 1992) reported this disenchantment anonymously, presumably because of the Confidentiality Agreement:

"We took a position we all agreed with, and I'd just as soon not be burdened with the notion that we've signed off on NIH's decisions," says one [member of the Richards Panel], adding: "I'd like it well known that we don't agree with NIH's decision." Another member puts the same point more succinctly: "It'll be a cold day in hell before any of us will consult for the U.S. government again."

\footnotetext{
2 Feynman wrote up his experiences in the article "An Outsider's View of the Challenger Inquiry" (Physics Today. February 1988). About communicating with the press he wrote: "I did, however, keep talking to the press-openly, always giving my name. I didn't want any hocus-pocus about 'unidentified sources,' or anything...." For more of the Feynman model, see footnote 4 .
} 
But the worst aspect of the chasm between Healy and her independent consultants is likely to be the doubt into which the panel's report throws NIH's final conclusions-doubt which NIH adversaries such as Rep. John Dingell (D-Mich) are already moving to exploit.

I do not go along with this last editorial evaluation in Science. To me, one of the worst aspects of the chasm between Healy and her independent consultants is that the integrity of scientific consultation for the government has been compromised, because top officials of NIH-HHS have betrayed their responsibilities toward science, toward the scientific community, and toward the NAS. Furthermore, I object to characterizing Dingell as an adversary of NIH. Dingell is a supporter of NIH in the broad sense, and defends NIH in the long run against the actions of certain high officials (including NIH Director Healy) who are now compromising the integrity of NIH.

NAS evasion of responsibility. The NAS has taken no action that I know of to protest the way the NAS and the Richards Panel have been used and abused by NIH-HHS. I wrote to Frank Press last spring, concerning the responsibility of the NAS, but his reply was evasive (copies of the exchange are enclosed). Since the responsibility of the NAS is also involved via Gallo's election to the NAS in 1988, I wrote to the NAS Council to ask for a public investigation of possible misleading presentations, or misrepresentations, of his scientific contributions on that occasion. The Council replied that there would be no such investigation. ${ }^{3}$

I object to the abdication of responsibility by the President of the' NAS and by the NAS Council in the face of the NIH-HHS failures of responsibility, especially toward the NAS which was directly involved. Therefore I ask you to read my letter to Frank Press and my letter to the NAS Council as if they were addressed to you. Since the Council refused a public investigation, and since Frank Press did not use his leadership possibilities to object-let alone object strenuously-to NIH and HHS for their handling of the Richards Panel, I am now turning to you directly with further information for action on your part at the grass

3 Copy of the correspondence is enclosed. The exchange was reported in Science (5 June 1992) under the heading "Gallo wins one...". The Council's reply to me was thus interpreted by Science as a victory for Gallo. 
roots. For a start, I urge you to send a copy of this mailing to every member of your section.

\section{Serge Lang}

cc: Frank Press, Council of the NAS, Robert Gallo, Bernadine Healy, Louis Sullivan (Secretary, HHS), James Mason (Assistant Secretary, HHS), Michael Astrue (General Counsel, HHS), Members of the Richards Panel, David-COSEPUP Panel, Representative Dingell, John Crewdson, Science and Government Report (Dan Greenberg), Science (David Hamilton, Ellis Rubinstein, Fay Flam, Constance Holden, Daniel Koshland), Nature (Barbara Culliton, John Maddox), New York Times (Philip Hilts), Washington Post (Malcolm Gladwell), and the rest of the cc list of about 250 people.

Enclosures

\section{What They Said}

Exchange of letters between James Mason and Frank PressSamuel O. Thier, February-March 1990.

Exchange of letters between Lang and the NAS Council and Frank Press, April-May 1992.

Confidentiality Agreement.

Cover letter from Richards to Healy, 19 February 1992.

Comments by Fred Richards on the OSI Report, January 29 and $30,1992$.

Cover letter from Healy to James Mason, 27 March 1992.

Letter from Healy to Richards, 11 May 1992.

Reply from Richards, 12 May 1992.

Letter from OSI Director Jules Hallum to Healy, 20 March 1992.

"NIH Clears Gallo; Patent Probes Go On," Chemical and Engineering News, 11 May 1992.

"Dissent and Critique" from Dan Greenberg's Science and Government Report, 1 June 1992. 


\section{APPENDIX}

\section{Improper Use and Abuse of the National Academy of Sciences by HHS and NIH and Distortions of the Views of the Richards Panel by NIH}

This appendix documents several ways the Richards Panel was improperly treated by NIH, especially by NIH Director Bernadine Healy.

To a large extent, organizations have to rely on trust, because one cannot verify everything all the time. I provide documentation that neither the Gallo investigation by NIH nor top officials of NIH and HHS can be trusted. When trust breaks down because of institutional failures, the workings of an organization are shaken, and it is very complicated, time-consuming, and energy-consuming to engage in setting matters straight. When challenging official reports, I don't ask to be trusted. Although my documentation may appear bulky to some people, I think it is essential that you see the documentation so that you can form your own judgment. This appendix is meant as a preliminary guide.

\section{Muzzling the Richards Panel: The Confidentiality Agreement}

Originally the Richards Panel expected to speak out as reported in Science (22 June 1990) by Barbara Culliton, who wrote: "Sources say [Richards] committee members have promised not to discuss their deliberations until they are complete. At that point, they expect to 'speak out loud and clear.'" But it turned out very differently. At about the same time that the members of the Richards Panel saw the OSI Report in January 1992, they signed a Confidentiality Agreement presented to them by NIH. A copy of the Confidentiality Agreement is enclosed.

The existence of this Agreement was reported in the press, e.g. by Science ("The Richards Panel Tosses a Curve," 3 April 1992): "Members of the panel contacted by Science declined to discuss their report, privately expressing their frustration with a confidentiality agreement they were forced to sign by NIH." The Science article does not specify in what way they were "forced." The reader is thus left to wonder what is this overpowering force which NIH exercised over presumably independent scientists. NIH cannot insure "the fact and appearance of objectivity by the inquiry" unless the members of the Richards Panel are available to answer 
directly questions raised by members of the scientific community about their reports. I am shocked that the members of the Richards Panel accepted to sign this Confidentiality Agreement, thereby abdicating their responsibility to inform and respond to the scientific community directly at crucial times.

Indeed, versions of the OSI Report and the Richards Panel Report have been available to the press. At a time when newspapers such as the Chicago Tribune, New York Times, Washington Post, and the scientific press such as Science, Nature, Science and Government Report, Chemical and Engineering News have quoted and commented extensively on these documents, and the NIH Director herself has used the press to undermine the Richards Panel (see §4 and §5), it is particularly important that the members of the panel be available to answer questions publicly about these documents and other matters.

The Agreement contains a clause: "Notwithstanding the preceding sentences in this paragraph nothing contained herein shall bind the signer to refrain from commenting on the Final Report of this investigation, if and when it is publicly released in an authorized manner." This clause gives rise to another piece of manipulation. By letting the Richards Panel speak out only after the OSI Report is "publicly released in an authorized manner," HHS and NIH are allowed in the meantime to misrepresent, suppress, and distort data with impunity, to support the exculpatory views of NIH Director Healy (cf. the conclusion of this Appendix). Without speaking out, the Richards Panel becomes an accessory to these misrepresentations, suppressions, and distortions. With the above clause, NIH and HHS not only forbid the Richards Panel from countering their manipulations and misrepresentations as they occur, but they have the prerogative to postpone, perhaps indefinitely, a public release "in an authorized manner," thus muzzling the Richards Panel possibly for a long time, if not indefinitely. However, it turned out that some members of the Richards Panel expressed their discontent to the press anonymously, so NIH was not entirely successful in its muzzling attempts.

\section{§2. The Richards Panel Did Not "Oversee" the OSI Investigation}

Although according to the letter from Frank Press and Samuel O. Thier to James Mason, the Richards Panel was to "oversee" the NIH investigation, the panel did no such thing. I shall present two pieces of evidence for documentation. 
(a) Bypassing of the panel. When the OSI Draft Report came out in 1991, the Richards Panel was at first bypassed, as reported by Crewdson (Chicago Tribune, 17 June 1991):

\section{AIDS inquiry bypassing watchdog panel}

A panel of distinguished scientists set up to ensure the objectivity of the government's investigation of its most prominent AIDS researcher, Dr. Robert C. Gallo, is being denied a chance to review the draft report of the 16-month investigation.

One panel member said that while the group has not yet decided how to respond to the rebuff, a mass resignation to protest the decision "certainly remains an option."...

The panelists discovered they were out of the loop last month, when Bernadine P. Healy, the new NIH director, abruptly canceled a May 20 meeting at which they were to have reviewed the Gallo Report.

In a letter faxed to the panel five days before the scheduled meeting, Healy said "issues of fundamental fairness, as well as concerns for ensuring the security of the draft report," had led her to decide that Gallo should be given the report before the panel....

One of the panel members said the panel's chief concern was that both the scientific community and the public would incorrectly assume that the Gallo Report had been "blessed" by the panel members when it had not even been seen by them....

The abrupt cancellation of the May 20 meeting was also later reported in Science (21 June 1991):

\section{Scientists Get Mad at OSI-NIH}

NIH's investigative agency is coming under fire in two celebrated cases involving Robert Gallo and David Baltimore Richards Panel: Out of the Loop?

... The [Richards] panel had planned to meet last month with the Office of Scientific Integrity (OSI), which produced the report, but to the dismay and annoyance of panel members, that meeting was canceled at the last minute, adding the panel members' voices to the growing chorus of critics of the way NIH conducts its inquiries into scientific misconduct.... 
(b) No gumshoe work by the Richards Panel and suppression of evidence by NIH. The panel ultimately commented on a document which was presented to them, apparently with no attempt to find out, for instance, if evidence was withheld from them. In other words, they did not do "gumshoe" work. ${ }^{4}$ There is some evidence that NIH suppressed information in its Final Report, and that the Richards Panel did not "oversee" this suppression. To some extent, the Richards Panel was maneuvered out of the possibility of overseeing this suppression. ${ }^{5}$ Some specific items will be mentioned in the next paragraph.

4 Compare with Feynman's gumshoes when he was on the Challenger Commission. The following excerpt from Feynman's book "What do you care what other people think?" is relevant here:

"Well, that's the point," Senator Hollings says. "From my experience in investigating cases, I'd want four or five investigators steeped in science and space technology going around down there at Canaveral talking to everybody, eating lunch with them. You'd be amazed, if you eat in the restaurants around there for two or three weeks, what you'll find out. You can't just sit and read what's given to you."

"We're not just going to sit and read," Mr. Rogers says defensively. "We've gotten a lot of people in a room and asked them questions all at the same time, rather than have a gumshoe walking around, talking to people one at a time."

"I understand," says Senator Hollings. "Yet I'm concerned about yo' product if you don't have some gumshoes. That's the trouble with presidential commissions; I've been on 'em: they go on what's fed to 'em, and they don't look behind it. Then we end up with investigative reporters, people writing books, and everything else. People are still investigating the Warren Commission Report around this town."

Mr. Rogers calmly says, "I appreciate your comments, Senator. You'll be interested to know that one of our commission membershe's a Nobel Laureate-is down there in Florida today, investigating in the way you'd like him to investigate."...

So I saved Mr. Rogers a little bit. He saw that he had an answer for Mr. Hollings by the good luck that I stayed in Florida anyway, against his wishes!

5 I do not ask that the Richards panel report be taken on faith any more than any other scientific document. I have some reservations myself about some of its statements, for instance a statement on page 4: "The thoroughness of the Investigation appears to be excellent. Two sides to each allegation are clearly and well presented. However, we do question the validity of the analysis and conclusions in certain instances...." Although over many pages the OSI Final Report appears at first glance to present two sides concerning "allegations" clearly and well, in certain crucial instances the OSI Final Report does not present certain allegations clearly and well. See footnote 1 . Actually, Richards himself hedged by using the word "appears" (to be excellent). 


\section{§3. Lack of Verification of the OSI Final Report}

The OSI Final Report was issued 18 March 1992, and was forwarded by Healy to James Mason with her cover letter of 27 March 1992. However, the response of the Richards Panel "Response to the charge to the consultants..." is based on a version of the report put out in January 1992. Three changes were made in the meantime, between January and March, as stated factually in a 20 March 1992 letter from OSI Director Jules Hallum to Healy. (A copy of this letter is enclosed.) Healy stated in her cover letter to Mason that these changes were only in "three minor respects." However, according to the letter from Hallum to Healy, one of these respects was "a short summary of the OSIcommissioned HIV sequencing analysis and its significance to the investigative findings." This summary of the sequencing analysis confirms that the isolate HTLV-IIIb, which was used by Gallo to test his HIV blood test, actually is LAV-LAI (i.e. the French virus). I therefore challenge Healy's characterization of this sequencing analysis as a "minor respect." In any case, the final version of the OSI Report contains items which were not in the version of the OSI Report made available to the Richards Panel in January 1992.

Even more significantly, the OSI Final Report fails to include some important findings and implications of the sequencing analysis. For instance, the summary does not mention that MO(V), another isolate used by Gallo to make and test his HIV blood test, is also LAV-LAI. ${ }^{6}$ A fortiori, the Richards Panel had no opportunity to comment on these findings.

What is the point of nominating a panel of consultants to "oversee" "with a view to insuring the fact and appearance of objectivity" and to get "informed, unbiased judgments" if the members of this panel are not even shown the final version of the OSI Report nor asked to comment on this final version, and if important findings such as those of the sequencing analysis are not even included in this final version? NIH and HHS undermine their own credibility by having failed to submit the complete findings of the sequencing analysis to the scrutiny of the Richards Panel in the January 1992 version.

By depriving the Richards Panel of the opportunity to see certain additions in the OSI Final Report, and to understand what

6 On the other hand, these results of the sequencing analysis are mentioned in the excerpts from the "Critique" quoted by Dan Greenberg, see footnote 1 . 
was omitted before they put out their comments, NIH impaired the Richards Panel's ability to evaluate the decision by NIH not to determine the extent to which the use of the French viral isolate by Gallo was inadvertent, and not to pursue the investigation on this central point.

\section{Overriding the Richards Panel with Other Consultants}

When Frank Press and Samuel O. Thier agreed to nominate a panel to oversee the NIH investigation, they took seriously and in good faith the stated intent by HHS to insure "the fact and appearance of objectivity by the inquiry." As a result, they specified that HHS would use only their nominees on the panel. This point was of such importance that it was specifically reported in the press, for instance by Barbara Culliton in Science ("NIH Goes the 'Extra Mile' on Gallo," 23 February 1990, p. 908): "Press and Thier have agreed to propose such a panel with the stipulation that Mason confine his selection to that list and agree not to add anyone recommended by the government, which can be said to have a stake in the outcome because it is a signatory to the U.S.French agreement...." NIH Director Bernadine Healy breached the spirit of the understanding between HHS and the NAS by using "her own committee of advisers" above and beyond the Richards Panel. To the extent Healy used her own advisers (who were therefore chosen by the government and not the NAS) to override the Richards Panel, she went against one of the criteria given by the presidents of the NAS and of the NAS Institute of Medicine to insure an independent overseeing of the OSI investigation. What credibility can then be attributed to NIH and HHS officials, to the NIH investigation itself, and to its exculpatory conclusions?

When the Richards Panel delivered its comments, NIH Director Healy not only referred these comments to "her own committee of advisers," but she also used these advisers and the press to undermine the credibility of the Richards Panel. She put forth public statements to the effect that Gallo had convinced her and "her own committee of advisers" that Gallo had "compelling" objections to the report of the Richards Panel, without NIH or Gallo being accountable on the record for their stand. For example, Barbara Culliton wrote in Nature (7 May 1992):

Then, going one step further, Healy called Gallo before her own committee of advisers for three hours on the night of 23 March and challenged him, in effect, to rebut the allega- 
tions of the Richards Committee. According to Healy, and others who participated in the interrogation, Gallo did just that. In the words of one participant, "he blew the directors away, including those prejudiced against him." Whether that is an exaggeration or not, participants agree that Gallo presented compelling evidence in his defense....

Thus Healy and her other consultants achieved an exculpatory effect via Nature, but they acted improperly vis-à-vis the Richards Panel and the NAS. Culliton's article documents:

- The irresponsibility of NIH and HHS in allowing a situation to develop when the scientific community is informed through such press articles, without NIH or Gallo being accountable on the record for their respective positions.

- Improper manipulation of the Richards Panel by NIH, which did not give the panel a chance to evaluate and answer Gallo's rebuttal, or the opportunity to have the panel's point of view accessible on the record to the scientific community. I don't see any justification for having Gallo's "interrogation" carried out before Healy's "own committee of advisers" and not before the Richards Panel itself, on the record.

- The undermining of the Richards Panel in the press by NIH Director Healy and her other consultants.

\section{\$5. Healy Undermining the Richards Panel in the Press}

Not only did Healy use Barbara Culliton in Nature to undermine the findings of the Richards Panel in the press, but she also used the Washington Post. Malcolm Gladwell's article "NIH Vindicates Researcher Gallo in AIDS Virus Dispute" (Washington Post, 26 April 1992) was based on the OSI Final Report and a discussion about the report with Healy, thus giving rise to an item in Science (1 May 1992) under the heading: "NIH Leak Policy Honored in the Breach." This item started: "When is a leak not a leak? Answer: When it comes from the head plumber...."

In his article, Gladwell undermined the Richards Panel, for example as follows: "The Richards Panel neither met with Gallo during the course of its deliberations nor gave him a chance to respond to accusations. When Healy met with Gallo last month and gave him for the first time an opportunity to defend himself against the consultant panel's charges, she found many of Gallo's answers convincing, she said later." These sentences are highly tendentious on several counts. First, Gallo did meet with some 
members of the Richards Panel in July 1991 and gave a presentation of his point of view. Second, in §2(a) above we have seen how Healy did show the OSI Draft Report to Gallo, thus giving Gallo a chance to respond. Third, the Richards Panel comments were based on the documentation provided by the January 1992 version of the OSI Report, which had already taken Gallo's response into account. ${ }^{7}$ Fourth, concerning Healy's meeting with Gallo and what "she said later," we have seen in $\$ 4$ how Healy improperly treated the Richards Panel when she interrogated Gallo in front of other consultants instead of interrogating Gallo in front of the Richards Panel.

Thus we see how Healy and the Washington Post cooperated to discredit the Richards Panel and its conclusions.

\section{Healy's Distortions and Misrepresentations of the Views of the Richards Panel}

(a) Healy's exchange with Fred Richards. On 11 May 1992, Healy wrote to Fred Richards: “... OSI findings pertinent to Dr. Gallo's management and scientific leadership will be forwarded to [a subcommittee of the National Cancer Advisory Board]. This will include your written comments on the OSI Report and the doubts you have expressed to us about these comments based upon a conversation you had with Dr. Gallo."

This last sentence is improper on several counts, for instance because Healy states that the Richards Panel had "doubts" about their comments. The very next day (12 May 1992), Fred Richards countered in a reply: "I have no doubts about our comments then or now. In our phone conversation I specifically stated that the Comments were based on the written report from OSI, and that, if there were relevant errors of omission or commission in that report, some of the Comments might be reexamined by the panel, but a single hurried phone conversation with Dr. Gallo is not an adequate basis for reconsideration.... To imply that the consultants may not stand behind the evaluation stated in the Comments would be a serious distortion of their views." Science reported this exchange ("The Last Gasp of the Richards Panel," 22 May 1992).

7 In fact, the OSI Final Report suppressed testimony by Gallo concerning what isolates he had, when he had them, and what he could use them for. But this leads into an open-ended critique of the OSI Report, which is not our main object here. See footnote 1 . 
(b) Healy's forwarding letter to James Mason. Nevertheless, when Healy forwarded the OSI Final Report to James Mason, she already invoked the Richards Panel tendentiously and also misrepresented the Richards Panel. In her cover letter of 27 March, she wrote:

The proposed final investigative report was submitted to me on January 17, 1992. I reviewed the report, and on various aspects of the case sought the consultative advice of: a group of external consultants known as "the Richards Panel"; a group of distinguished individual consultants from the intramural laboratories of the $\mathrm{NIH}$ (other than the NCI); and two scientists from the extramural community. Most of the scientific consultants are members of the National Academy of Sciences and none are scientific collaborators with the laboratory under investigation. The formulation of this transmittal memorandum was substantially assisted by the knowledge, advice and perspective of the individual consultants....

Healy's phrase "substantially assisted by the knowledge, advice and perspective of the individual consultants" is tendentious in its suggestion that members of the Richards Panel would go along with her conclusions. Further on in her letter, Healy downright misrepresented the Richards Panel as follows:

The consultants were in general agreement that OSI findings on Dr. Popovic were fair and appropriate but "nickel and dime stuff"....

The consultants believed that it would be impossible to determine definitively whether there had been inadvertent contamination or misappropriation of a French virus, resulting in the appearance of LAI in the reported cultures....

Note that Healy refers to "the consultants," thus involving all the above-mentioned consultants without exception. I question the legitimacy of Healy's reference to "the consultants." The Richards Panel certainly did not regard the transgressions of Popovic and Gallo as "nickel and dime stuff." Healy's formulation of the alternative "inadvertent contamination or misappropriation" is also questionable. In fact, the Richards Panel charged "intellectual appropriation." More precisely:

- The Richards Panel blamed the OSI Report because it "fails to integrate its findings in a larger context, namely a pattern of behavior on Dr. Gallo's part that repeatedly misrepresents, suppresses, and distorts data and their interpretation in such a way 
as to enhance Dr. Gallo's claim to prority and primacy..."

- The Richards Panel further wrote: "The Gallo lab 'went to school' with the French virus, yet they later failed to mention the fact that they had propagated the French virus. In fact, they denied propagation of the French virus and stated (in the Popovic et al. manuscript) that the French virus had never been transmitted to a permanent cell line. Given the quality of the information derived from propagation of the French virus, we believe that this constitutes intellectual recklessness of a high degree-in essence, intellectual appropriation of the French viral isolate..." [underlining in the original].

"The statement that LAV [the French virus] had not been transmitted in a permanent cell line is simply false, and was known to be false at the time the paper was written. This is one of the most glaring faults in the paper and is part of the pattern of misrepresentation in the discussion of the problem of continuous culture. There is no way in which Dr. Gallo can be excused from sharing the blame for this misstatement."

- In addition, some members of the Richards Panel have expressed publicly their disagreement with OSI and Healy, as when one member was quoted by David Hamilton in Science ("RICHARDS PANEL Scientists-Consultants Accuse OSI of Missing the Pattern," 8 May 1992): "I'd like it well known that we don't agree with NIH's decision." That same article in Science also stated:

"We thought our report was a reasonably serious document questioning the whole state of affairs [in the Gallo lab]," says one panel member. "We told Healy that if it had been our [investigation], we'd have recommended that Gallo be found guilty of misconduct." Instead, this member says, Healy has not acknowledged receipt of the report, and has since told the Washington Post that Gallo defended himself effectively against the Richards Panel's charges.

Thus NIH Director Healy grossly misrepresented the Richards Panel, and some members of this panel reacted via Science, but anonymously.

In summary, Healy forwarded the OSI Final Report to James Mason:

- without giving the Richards Panel the opportunity to comment on the final version of the report;

- after involving other consultants and after Gallo's interrogation of 23 March 1992 in front of these other consultants but not in front of the Richards Panel; 
- without mentioning the very serious disagreement of the Richards panel with some of the conclusions of the NIH Final Report, thus suppressing relevant information;

- actually misrepresenting the position of the members of the Richards Panel by referring to "the consultants" taking a position on certain items, when the Richards Panel in fact took an opposite position.

Therefore I have documented:

- how Healy manipulated and invoked the Richards Panel improperly, and how she discredited the original solicitation from James Mason to Frank Press and Samuel O. Thier, to nominate an independent group to "oversee" the NIH investigation;

- the extent to which Healy illegitimately covered herself with those consultants and with the NAS.

\section{Envoi}

I can apply the words of the Richards Panel to the documentation and analysis I have provided here. I have integrated my findings in a larger context, namely a pattern of behavior on the part of top officials of NIH (especially NIH Director Healy) that repeatedly misrepresents, suppresses, and distorts data and their interpretation in such a way as to enhance Healy's claim that transgressions in Gallo's laboratory were merely "nickel and dime stuff," and that there was no "misconduct" on Gallo's part.

Unlike others who tend to formulate scientific standards in the straightjacket of legal terminology, I do not ask whether a generic word such as "misconduct" applies to the above pattern of behavior. However, I do ask the NAS and the scientific community whether they will tolerate this pattern without taking action against it. S.L.

\section{Update, January 1995 \\ From the Dingell Subcommittee Staff Report}

[After the appearance of the Dingell Subcommittee Staff Report, more information came to light about Healy's manipulations of the scientists around her. I quote from page 57 of this Staff Report.]

... Dr. Healy bypassed the [Richards] Committee and commissioned her own committee of NIH scientists whom she called her "wise men." Dr. Healy told her "wise men" that everything about the committee and their participation would be completely con- 
fidential. In return, she-without any advance warning- required the committee members to sign a secrecy agreement. As a consequence, the very existence of the committee remained hidden for nearly two years.

Despite Dr. Healy's efforts to handpick and control "wise men," they decided Dr. Gallo should be fired as an NIH lis watory chief. One committee member expressed this determination as follows:

“... Gallo failed in his responsibilities as the head of thie laboratory. His behavior was seriously discordant with the 'guidelines for the Conduct of Research in the Intramural Research Program at the NIH'... The consequences of Gallo's failings have been substantial. At a minimum, an enormous amount of time and effort has been spent on these investigations, the efforts of both the French and American groups have been diverted into unproductive activities and considerable damage has been inflicted on the scientific enterprise, in general ... I recommend that $y$. remove Dr. Gallo from his position as chief of the laboratory...."

Faced with a finding she clearly did not want, Dr. Healy convened a second meeting of her committee. At this meeting, the "wise men," who had been assured that everything about the committee was entirely secret, suddenly found themselves confronted with Dr. Gallo and his attorney. The committee members were required to sit through a lengthy and entirely one-sided presentation by Dr. Gallo and his attorney in which all wrongdoing was denied, and in which it was suggested that Dr. Gallo was being hounded for accidental errors and inadvertent sloppiness in laboratory notekeeping - "that could happen to any of you." At the conclusion of the meeting, Dr. Healy demanded a ruling from the committee as to whether Dr. Gallo had committed scientific misconduct. The committee members, who had examined none of the evidence, said they could not make such a judgment.

Dr. Healy's immediate response was to grant interviews with the Washington Post and Science, during which she disclosed the existence of her committee, and claimed Dr. Gallo "rather effectively refuted" the charges against him. At the same time, Dr. Healy quoted selectively from memoranda written by the committee members, attempting to trivialize the negative aspects of Dr. Gallo's conduct. Dr. Healy never acted on her committee's recommendation that Dr. Gallo be fired. 


\section{INTERLUDE: JOURNALISTIC OBSTRUCTIONS}

My open letter of 1 September 1992, addressed to all Section Chairs of the National Academy of Sciences, reproduced in the preceding section, gave a summary presentation of the way $\mathrm{NIH}-$ HHS and NIH Director Healy mistreated the Richards Panel, nominated by the National Academy of Sciences to "oversee" the Gallo investigation at the request of NIH-HHS. In so doing, she undermined the integrity of scientific consultation. My open letter was backed up by enclosures consisting of 40 pages of documentation. This documentation is important in and of itself, independently of me, partly because it gives evidence for an objectionable pattern of behavior on the part of top officials of $\mathrm{NIH}$ (especially NIH Director Healy), namely a pattern of behavior that repeatedly misrepresents, suppresses, and distorts data and their interpretation in connection with the Gallo investigation and the role of the NAS-nominated panel.

I submitted my 10-page open letter for publication in Nature. Nature's editor John Maddox asked that it be "drastically shortened." I refused to shorten it, and he refused to publish it. Although he wrote me that my open letter "contains a great deal of interesting material," he did not publish any of that material either, and so Nature's readers were not informed about the 40 pages of documentation which I sent out in the mailing of 1 September 1992.

1. My responsibility. Since Nature's readers have not been properly informed of this documentation, which is independent of me, I refused to take responsibility for a "drastically shortened" piece in which I would have to inform readers about many facts and documentation which Nature failed to provide previously, while at the same time I would have to organize these facts in a pattern and provide an analysis of them. Let Maddox try to do this job in "drastically shortened" form and see how far he gets. It isn't for me to take Nature off the editorial hook by accepting to 
do a necessarily inadequate job with slivers of information and undocumented or poorly documented assertions or generalities, which would give the illusion of Nature being journalistically responsible, when in fact Nature's journalism has been defective for a long time, because Nature did not properly report the pattern of behavior of top NIH officials.

2. Nature's responsibility. Maddox also replied to me: "Sadly, my long experience has taught me not to consider publishing contributions from people who say that their contributions cannot be shortened." Maddox thus transfers the responsibility of non-publication to me. However, it is for Maddox to treat the matter as one of professional responsibility to inform Nature's readers, rather than one of personal dealings with me. Maddox's answer is defective on several counts:

(a) He covers himself with a universal criterion about "people," as if the problem he was facing was due to a defect in me lamong other "people"), instead of dealing with the merits of the given situation. Different amounts of documentation are needed at different times to deal with different issues, as far as I am concerned, but not according to the answer Maddox gave me. He bases his editorial decision whether to publish "interesting material" only on a factor having to do with "people" who submit material to his attention, and not on the merits or the importance of the documentation in relation to the case under consideration.

(b) Even though he accepted that there was "a great deal of interesting material," he makes no analysis of the significance and coherence of this material, nor does he even consider taking upon himself the responsibility of shortening this material. For instance, I asked that the Confidentiality Agreement imposed by NIH on consulting scientists be printed in full because of its importance as an official document which reveals a great deal about the way NIH-HHS and some scientists function in official positions. It is not my responsibility to shorten this document drastically. Let Maddox take this responsibility as editor of Nature. In fact, he has taken the responsibility by shortening the document to the empty set, as far as readers of Nature are concerned.

The 40 pages of enclosures accompanying my open letter to the NAS Section Chairs document an intricate and extensive web of failures of responsibility by top NIH and HHS officials. The enclosures included extensive primary sources besides the Confidentiality Agreement, for instance letters from NIH officials and from the NAS-nominated panel, as well as official NIH and HHS statements to the press. These letters and public statements docu- 
ment inconsistent behavior of NIH and HHS officials at different times, and in particular, the way they go against their own public commitments. To do what I thought was a responsible job of summarizing the documentation coherently, instead of just charging NIH-HHS officials in generic terms, or asking to be taken on trust, I found that I needed all of my 10 pages.

(c) It is Maddox's responsibility, not mine, to explain to Nature's readers why they have not been properly informed about the doings of NIH, HHS, and Healy, and to provide Nature's readers with comprehensive documentation. Maddox can do so by an article of his own on the "great deal of interesting material" which I put together. This material is not my personal property, and it is Maddox's responsibility as editor to extract whatever he wants from the primary sources and documentation which I put together and whatever other documentation is available to him. So far he has withheld this documentation from Nature's readers. As a result, these readers lack information about NIH and HHS which would help them to understand the operations of those organizations.

Maddox's letter to me reveals a great deal about the way he arrives at editorial decisions for one of the major science magazines in the world, and how information is withheld from Nature's readers. My experience is by no means isolated. I urge readers to read the exchange between Maddox and Neville Hodgkinson (the science editor of the London Sunday Times). This exchange is dealt with in my essay "HIV and AIDS: Questions of scientific and journalistic responsibilities." Readers will see how Maddox refused publication of material adverse to the established view on the HIV causality of AIDS. 


\section{AN EXCHANGE WTH GALLO}

On 12 May 1992, Gallo called me on the phone. The conversation lasted about 10 to 15 minutes. Gallo did most of the talking. He accused me of writing without knowing the facts. I said practically nothing except that I awaited the NIH report being made public, and the Richards Panel Report being made public officially. I stated that I stood by what I wrote. I also said that I was about to leave within a couple of days for Europe where I had to give some lectures in various places.

Around the middle of November, I received from Gallo a letter dated 5 November, and running as follows.

\section{Gallo's Letter to Me}

Dear Dr. Lang:

I have seen your recent letters to the Academy. Your continued references to me regarding matters about which you have no facts and certainly no understanding of, are deeply disturbing and shocking.

You are wrong in your understanding of the events concerning our HIV research or you have been misled. What you have not perceived in any of your harangues is what I meant by the question "are you crazy" and the comment "this is incredible," which I marked in Popovic's first manuscript. Moreover, neither has Dr. Richards realized the context of these comments. You and Dr. Richards know none of the background, none of the reasons, none of the purposes of those remarks. An outline fragmentary explanation follows:

(1) I had little idea of how much or long Popovic cultured LAV. Indeed, he always indicated to me it was very short term.

(2) Indeed, LAV grew only with great difficulty. Another HIV (in 1991 identified as LAV) contaminated one of the French cul- 
tures in the summer of 1983. It is LAI that also contaminated a few of ours, and that was inadvertently grown. The true LAV could only be grown with great difficulty. That is true today. Indeed, the Pasteur group had said it was impossible to grow LAI in a cell line. Those were facts that impressed me.

(3) Popovic was not my only co-worker making HIV isolates. I was preparing 3 other Science papers and 1 Lancet paper for publication with the full belief that all of our many isolates were from our lab. Most were. We had several other isolates. It is media distortions and the manipulations of a few that say otherwise.

(4) In July 1983, Montagnier, of the French group, told me he wanted the analysis of "LAV" to be done in France. In other words, we were to avoid doing it alone. In Popovic's early draft he simply wrote LAV was transmitted transiently in a cell line. In and of itself, this statement is useless, unless the virus is analyzed. Indeed, I thought the statement bizarre without more data. As a group, we discussed an alternative which I believe was quite honorable. I would go to Paris immediately (I did, within 1 week of submission of our papers. I would tell them our results (I did)). I would arrange for an immediate collaboration (I did). My co-worker came to Paris the following month, and within a few months papers co-authored by the French and us were ready. These papers were available to see, but Dr. Richards apparently never saw them. Montagnier later decided against publishing them because a more detailed analysis (full nucleotide sequencing of the whole genome) of one of our isolates and theirs would soon come out.

Do you honestly believe I was "hiding" culturing the "French" virus when such data is included in these papers only a few months later? This is absurd.

As to your other point that in the Popovic et al. paper I denied culturing LAV in a cell line but in fact, we had succeeded in doing so, is a flagrant misrepresentation. Every scientist who I spoke with who read the paper in its full context understood that that statement was in reference to the published literature. It was in the Discussion. The Discussion implies LAV and our isolates may be the same subtype, but there were differences (in the literature) of some LAV characteristics and what we knew of our isolates. Then I go on to say or imply that these differences may be artifactual (technical) because of insufficient production of LAV because it has not been produced in a continuous cell line. Obviously, I was referring to the French group, not to what we had 
recently (and my thoughts quite transiently) succeeded in doing. Is that wrong? Is that unethical? What should I have said: The French couldn't do it, even said it was impossible, but we just succeeded?

You seem to believe I forced everyone to follow this approach. We all ultimately agreed this was the best thing to do. The OSI Inquiry Team understood this very well. They read the papers. They interviewed us. They found no misconduct. NIH scientists reviewed it, and understood it perfectly well. Yet you sit in judgment with no understanding and cast stones!

You are also wrong and mean spirited about the "narrowness" of my scientific contributions for entry into the Academy. Though it is a bit degrading to discuss this, let me at least remind you that it means something to most scientists that I received the Lasker Prize (usually regarded as the highest prize in the U.S. biomedical science) before AIDS. (I also received a second one for AIDS.) In addition, I also received other recognition from peers, like the General Motors Cancer Prize, the Israel Cancer Prize, and the French Griffuel Prize, among others; all for cancer research prior to AIDS. I was also the most cited scientist in the world for the decade of the 1980s. In all fairness, is that so narrow?

But none of this is really the issue. I have been a target. Much of it, in my opinion, is derived from and planned by people maneuvering over patent money and using the media. A few more joined in this when they saw a chance to make publicity for themselves. In this isolated position, a fellow victimized colleague could greatly use the help of someone with your energy and dedication. Instead, you are helping forces of repression, greed, hatred, jealousy, and ignorance.

If you would like a fuller understanding of these issues, I would be pleased to review with you and to document these events. I realize your notions are greatly colored by Dr. Richards' letter. Please keep in mind Richards has never met me, never questioned me, and states he did not look at our responses to OSI. Thus, he knew only what he was told by Ms. Hadley, a psychologist working for Mr. Dingell. Please also know that the only scientific committee that reviewed our records in detail, interviewed me (more than 20 lengthy interviews) were the OSI Inquiry Team (Hadley chaired it). They made no such criticisms of me. They found no misconduct. No scientific investigators found me guilty of anything. Richards, as he himself noted, was an outside advisor in a unique position, i.e., having influence with little information. This was a novel process, and in my opinion, one that did not work well. 
The conclusions you harshly drew about me in your letters were not made by anyone who was involved in the investigations and reviewed the evidence first-hand. Thus, how can you make such statements? With this in mind, don't you believe you are unfair to me, when instead you could be helpful? I realize that may be asking you to have the courage to change your direction in a way that may be against your nature. I hope you will.

You have publicly complained that you did not get a reply from your Russian mathematician colleague. I hope you will be consistent in your views that people properly answer their letters and answer this letter, and I hope it is not in the way of avoiding an answer by stating "you stand on your opinion" as you told me by telephone.

\author{
Sincerely yours, \\ Robert C. Gallo, M.D. \\ Chief \\ Laboratory of Tumor Cell Biology
}

RCG:kap

cc: Mr. Joseph Onek

Dr. Frank Press

Dr. Fred Richards

Some items in Gallo's letter refer to letters which I wrote in the context of the Shafarevich case, and which are reproduced in the last section of this book. Readers can verify for themselves that Gallo in fact misrepresents what I wrote in those letters, for instance in his reference to "narrow" scientific contributions-a term which I used in a well-defined sense in my "Comments on the Meaning of Membership in the National Academy of Sciences."

$B e$ that as it may, I replied as follows to Gallo's letter on 30 November 1992.

\title{
My Reply to Gallo
}

Dear Dr. Gallo:

This is to acknowledge receipt of your letter of 5 November. How is one to respond to a letter such as yours? Your letter contains a tissue of invalid points based on misrepresentations of the record, numerous inaccuracies, misrepresentations of what I have writ- 
ten, and is incoherent overall. Not only does your letter lack specific mention of what I have written, but it also raises concerns which do not necessarily relate to my own views, but to the views of others which I report. I cannot deal with all objectionable items of your letter, but I shall provide specific examples of my objections in several categories:

I. The OSI investigation.

II. Conclusions about your conduct.

III. Misrepresentations by you concerning your handling of the French virus.

IV. Issues of responsibility.

V. Answering your letter and phone conversations.

Your letter begins with the sentence: "Your continued references to me regarding matters about which you have no facts and certainly no understanding of, are deeply disturbing and shocking." However, you do not state specifically which ones of my "continued references" disturb and shock you. I have mentioned you in two mailings this fall:

- The first one of 1 September contained three pieces: a letter from me to all NAS Section Chairs; 40 pages of enclosures consisting of original documents and primary sources; and my letter to Congressman Dingell asking for his help in abrogating the NIH Confidentiality Agreement. This mailing dealt primarily with the integrity of scientific consultation, and the way it has been undermined by NIH, HHS, and NIH Director Healy. As I stated explicitly at the beginning of my letter to all NAS Section Chairs, this issue "transcends the Gallo case."

- The second one dealt partly with the Shafarevich case, and contained four pieces, notably my 12-page essay "Comments on the Meaning of Membership in the NAS." In this essay I went beyond the Shafarevich case, and among other things I compared several cases to illustrate various criteria for membership in the Academy. Among these cases, I mentioned your own case.

I see no point in reproducing my mailings here, but I stand by what I wrote in them. 


\section{Part I. The OSI investigation}

\section{Misrepresentations concerning the factual basis}

of my mailings. You write: "Your continued references to me regarding matters about which you have no facts and certainly no understanding of, are deeply disturbing and shocking."

Your unqualified statement that I "have no facts" is false. To mention here only one example, in my malling of 1 September, I reported accurately the existence of a sequencing analysis which confirmed that the isolate HTLV-IIIb, which you used to test the HIV blood test, actually is LAV-LAI (i.e. the French virus). The existence of the sequencing analysis is a fact which was mentioned in a letter from OSI Director Jules Hallum to NIH Director Healy of 20 March 1992. I enclosed the Hallum letter in my mailing to provide appropriate documentation for my cc list.

\section{Misrepresentations concerning the OSI investi-} gation. You write, concerning the OSI investigation and NIH scientists:

The OSI Inquiry Team understood this very well. They read the papers. They interviewed us. They found no misconduct. NIH scientists reviewed it and understood perfectly well....

... Please also know that the only scientific committee that reviewed our records in detail, interviewed me (more than 20 lengthy interviews) were the OSI Inquiry Team (Hadley chaired it). They made no such criticisms of me. They found no misconduct. No scientific investigators found me guilty of anything. [your underlining]

Some of these statements are false, and some are misrepresentations, on several counts, as I shall document below. You misrepresent the history of the NIH-OSI dealings with your case, including the reactions of certain scientists advising NIH.

To start with, you were informed officially at the beginning of the OSI Inquiry that it was the role of the "OSI Inquiry Team" to determine whether there were grounds for a formal investigation. In other words, it was not their role to determine whether "misconduct" occurred or not. Even so, NIH Acting Director William Raub informed you that the Inquiry Team had uncovered "substantial reason to believe scientific misconduct may have occurred..." so that grounds for a formal investigation did exist, and the investigation took place with you and Dr. Popovic as subjects 
of the investigation. Raub also recognized publicly the serious need for the investigation when he said that "it's serious or we wouldn't be doing an investigation." 1

As to that investigation, the OSI Draft Report of June 1991 reached the following conclusions, directly quoted by Crewdson in the Chicago Tribune, 15 September 1991:

The investigative team considered if Dr. Gallo's actions as lab chief and senior author of the Science paper constitute scientific misconduct. The scientific advisory panel was not unanimous on this point, although all agreed there were serious problems with Dr. Gallo's conduct. [my emphasis]

Two members of the advisory panel believed a finding of misconduct should be reserved for specific, direct acts of falsification, fabrication, or plagiarism, which they believed did not apply with respect to Dr. Gallo. One member believed that misconduct applies as well [my emphasis] in the broader context of one's responsibilities as a senior author and laboratory chief.

Based on the provisions of the Public Health Service definition that defines misconduct in science as "other prac-

1 Both quotes from Raub are reported in John Crewdson's article "Health official reaffirms issues in AIDS lab probe," Chicago Tribune, 28 October 1990. I reproduce some relevant parts of this article:

William Raub, the head of the National Institutes of Health, has taken issue with his most prominent researcher over an unprecedented investigation into one of the government's most notable scientific achievements, the discovery of the cause of AIDS.

Raub also said in a recent interview that he was "surprised and disappointed" by what he has learned in general about the conduct of the government's most important AIDS research facility, the giant National Cancer Institute laboratory headed by Dr. Robert C. Gallo.

Earlier this month, Raub advised Gallo in a confidential letter that NIH investigators had uncovered "substantial reason to believe scientific misconduct may have occurred"....

Although the Gallo investigation is months from a conclusion, Raub said he had already discovered "a pattern of excess, in at least this laboratory and this institute, that's disturbing."

... In a recent letter to the Tribune, Gallo's Washington attorney, Joseph Onek, asserted that the probe was focused only "on minor issues which do not call into question either the validity of Gallo's papers or the work of his laboratory."

But Raub contradicted Gallo and his spokesmen, maintaining that the investigation "goes to the heart of an awful lot of things," and that "it's serious or we wouldn't be doing an investigation." 
tices that seriously deviate from those that are commonly accepted within the scientific community for proposing, conducting, or reporting research," this individual believed Dr. Gallo's negligent conduct as senior author and laboratory chief, coupled with his reckless disregard for accuracy and responsibility in the conduct and reporting of research, constitute scientific misconduct.... [my emphasis]

At the same time, the OSI, with the unanimous and strong concurrence of the scientific advisory panel, found that Dr. Gallo's conduct had in numerous respects fallen well short of the conduct required of a responsible senior scientist and laboratory chief.... [my emphasis]

Dr. Gallo failed in these responsibilities, and with respect to the matters examined in this investigation, he thereby created and fostered conditions that gave rise to falsified/fabricated data and falsified scientific reports. [my emphasis]

The investigative team believed that even though Dr. Gallo's actions do not meet the formal definition of scientific misconduct, they warrant significant censure. [my emphasis]

Therefore all those on the investigative team agreed that there were "serious problems" with your "conduct"; all of them found you guilty of some things which "warrant significant censure"; and one scientific adviser believed that "misconduct applies as well." These facts flatly contradict your unqualified statement: "No scientific investigator found me guilty of anything."

The OSI Report of March 1992 had a number of passages along the same lines. For example, an article by John Maddox in Nature (14 May 1992, pp. 107-109) described some "specific conclusions" of this report, among which (p. 108):

The claim in the published paper that virus samples had "first" been tested for the presence of reverse transcriptase is judged to be "not true," and the investigation also concludes that the addition of this sentence to the final draft of the paper "suggests that the misrepresentation was deliberate," that its purpose was to "increase the apparent rigor" of the culture procedures and that "this reckless disregard for truth in science" constitutes scientific misconduct. [my emphasis] The investigation says it has not been able to 
tell which of the authors added the misleading sentence.

Here the OSI Report does indeed arrive at a technical conclusion of "misconduct." As far as I am concerned, you (as well as the other authors) are responsible for such a "misleading sentence" in a paper you coauthored (you were senior author). Nature also reported several passages from the OSI Report objecting to "the lack of laboratory records," and giving examples "of lack of attention to detail which resulted in a false representation" as well as "dubious scientific rigor" and "lack of scientific rigor."

The OSI Report of March 1992 also repeated some items already contained in the Draft Report. For example, Nature (loc. cit.) states:

p. 108: The investigation concludes that the claim in the published paper that the culture was "continuous" even though it had been reinoculated on at least two occasions was not a misrepresentation. But one of the expert advisers strongly dissented [my emphasis], on the grounds that "a responsible author writes for the entire audience, not just the careful reader."

p. 109: The investigation's recommendations on Gallo are that he should be held directly responsible for four minor discrepancies out of the total of 20 , and that "he breached his overall responsibility ... to ensure the accuracy of the paper," but that this does not constitute misconduct. The report says that the outside advisers were split two to one on this recommendation [my emphasis], with the odd person holding that "Dr. Gallo's negligent conduct ... coupled with his apparent disregard in this instance for accuracy and responsibility in the conduct and reporting of scientific research, did constitute misconduct. Imy emphasis]

\section{My position on "misconduct"}

At this point, I would like to recall my own position concerning the use of the word "misconduct." I wrote this position clearly at the end of my letter of 1 September to all NAS Section Chairs, but since you systematically fail to mention accurately what I have written, I need to repeat my position here. Unlike others who tend to formulate scientific standards in the straightjacket of legal 
terminology, I do not ask whether a generic word such as "misconduct" applies to a pattern of behavior which, according to the OSI Report and the NIH scientific advisers, includes "lack of laboratory records. ... false representation ... lack of scientific rigor ... reckless disregard for truth in science ... reckless disregard for accuracy and responsibility in the conduct of research...." However, I do ask the scientific community whether it will tolerate such a pattern without taking action against it.

I also take notice of the remarkable conclusion which follows from the logic of those OSI investigators and scientific advisers who declared that there was no "misconduct" in the technical sense defined by the Public Health Service, namely "other practices that seriously deviate from those that are commonly accepted within the scientific community for proposing, conducting, or reporting research." Simultaneously, the OSI Reports, supported by the NIH scientific advisers, did object to a number of practices which I have set off above in boldface italic. Therefore one is entitled to conclude that according to OSI, the "lack of laboratory records ... lack of attention to details which resulted in false representation ... lack of scientific rigor ... breached overall responsibility ... to ensure the accuracy of the paper ... created and fostered conditions that give rise to falsified/fabricated data and falsified scientific reports" do not seriously deviate from practices that are commonly accepted within the scientific community. According to the OSI Draft Report, it also follows that a number of practices commonly accepted within the scientific community "merit significant censure." Since the phrase "merit significant censure" was subsequently deleted in the OSI Report of March 1992, one can further conclude that, according to this later view of the higher-ups in NIH, these practices do not merit significant censure.

\section{Misrepresentations concerning the Richards}

Panel. You write: "Please keep in mind Richards has never met me, never questioned me, and states he did not look at our responses to OSI. Thus, he knew only what he was told by Ms. Hadley, a psychologist working for Mr. Dingell."

Here and elsewhere you systematically misrepresent the nature and workings of the Richards Panel.

(a) Your statements about the Richards Panel (including the above) are written as if the Richards Panel was made up of Richards alone, which is not the case. 
(b) One thing I keep in mind, and which I clearly stated in my letter to all Section Chairs of 1 September 1992 (p. 8, §5), is that you did meet with some members of the Richards Panel and gave them a presentation of your point of view in July 1991. I do not know if Richards himself was present at that meeting, but even if he was not present, other members of the panel would report your point of view to him. Other members of the panel wrote exactly as he did concerning the OSI investigation of your case. Therefore your assertion that "Richards has never met" with you is misleading at best.

(c) I don't know where or to whom Richards "states" what you attribute to him, and you give no reference for your attribution. In any case, your "thus" is a non sequitur. How do you know what he "knew only" or when? In fact:

- Richards stated in his letter to Healy of 12 May 1992 that the Richards Panel report was "based on the written report from OSI."

- As reported by Crewdson in the Chicago Tribune of 15 August 1991: "Members of the Academy panel flew to Washington last month [July 1991] to read the draft Gallo report.... They also heard from Gallo, Popovic, and NIH Director Bernadine Healy." (Cf. (b) above.)

- The Richards Panel received many of your submissions to OSI before the OSI Report was issued.

Therefore your sweeping, unqualified assertion that "Richards ... knew only what he was told by Ms. Hadley" is documentably false, on several counts. ${ }^{2}$

(d) In characterizing Dr. Hadley as "Ms. Hadley, a psychologist working for Mr. Dingell," you describe her qualifications and position improperly, and you minimize her role. Contrary to what you imply, she was not working for Dingell at the time the OSI Report and the Richards Panel Report was issued. She was working for OSI. In fact, she was "chief investigator" for OSI in the Gallo case before she was forced off the investigation by NIH Director Healy. According to your own letter to me, page 3, line 13, Dr. Hadley chaired the OSI Inquiry Team. She is still associated with NIH, but since August 1992 she has been on detail to Rep. Dingell, a mission that was approved by HHS.

2 For further comments about aspersions on the Richards Panel, similar to those you make in your letter to me, see my letter of 1 September 1992 to all NAS Section Chairs, p. 8, §5. 


\section{Part II. Conclusions about your conduct}

You write: "The conclusions you harshly drew about me in your letters were not made by anyone who was involved in the investigations and reviewed the evidence first-hand. Thus, how can you make such statements?"

51. Dangling references. You do not quote any specific conclusion I personally drew about you. Your words "such statements" are dangling, without any reference to specific statements I made. It is not for me to presume which conclusions or statements of mine you have in mind. Some conclusions were made by others, whom I have sometimes quoted, and whose statements have also been quoted in the press. I reproduced a number of those statements in Part I above. I shall reproduce some more conclusions from others in the next two sections.

\section{Conclusions by OSI investigators and scien-}

tists. Your sentence "The conclusions ... were not made by anyone who was involved in the investigations and reviewed the evidence first-hand" is a significant misrepresentation. Dr. Hadley (whom you mention in the sentence quoted in Part I, § 3), was definitely "involved in the [OSI] investigation" and she reviewed the evidence first-hand. You yourself confirm her involvement in your letter to me, when you write that "the only scientific committee that reviewed our records in detail, interviewed me (more than 20 lengthy interviews) were the OSI Inquiry Team (Hadley chaired it). They made no such criticisms of me." In fact, the OSI Inquiry Team recommended that there be a formal investigation of possible scientific misconduct, with Dr. Popovic and you as subjects of the investigation, as recalled in Part I. This recommendation was accepted by NIH, and NIH Acting Director William Raub even said publicly that "it's serious or we wouldn't be doing an investigation," as recalled in Part I, see also footnote 1 .

The OSI Draft Report was later watered down in the version of March 1992. Then a report for the Dingell Committee, prepared principally by Dr. Hadley, was very critical of this Final Report, on the grounds that it "is a deeply flawed document reflecting an incomplete investigation.... Moreover, in a number of instances, OSI has failed to deal with and even mention highly significant pieces of evidence known to be in its possession." So the one person who 
chaired the OSI Inquiry Team and reviewed evidence first-hand did indeed reach certain conclusions, but was forced off the Gallo investigation by NIH Director Healy. Some of her conclusions appear in Dan Greenberg's Science and Government Report (1 June 1992), where Greenberg reproduces extensive excerpts from the "critique and dissent" prepared for the Dingell Committee. The Greenberg excerpts were sent as part of the enclosures of my mailing of 1 September, and are mentioned explicitly in footnote 1 of my letter to all NAS Section Chairs contained in that mailing. I see no reason to reproduce these excerpts here since I previously sent you copies of them, but I stand by the documentation which I provided in my mailing.

\section{§3. Conclusions by the Richards Panel and one of} my own conclusions. The Richards Panel also drew significant conclusions about you. In my essay "Comments on the Meaning of Membership in the NAS," I quoted some of these conclusions in addition to those of the OSI Report, when I wrote:

That [OSI] investigation was reported in various newspapers (Spring 1992) to have cleared Gallo of "misconduct," following the leak of a report by the NIH Office of Scientific Integrity. However, severe criticisms of the report surfaced immediately, and a special panel of consultants nominated by the NAS, at the request of HHS and NIH to oversee the investigation, actually charged Gallo with "a pattern of behavior ... that repeatedly misrepresents, suppresses, and distorts data and their interpretation ... intellectual recklessness of a high degree-in essence intellectual appropriation of the French viral isolate...."

Then I wrote my own conclusion:

Therefore, it may have been that the listings of Gallo's scientific achievements for election to the NAS were in error. I wrote to the [NAS] Council to ask for a public investigation of possible misleading presentations, or misrepresentations, of his scientific contributions on that occasion. The Council replied that there would be no such investigation.

I stand by my conclusion and by my (thwarted) request for an NAS investigation of the conclusions of the Richards Panel, not only as they concern your election in particular, but also as they concern general criteria for election to the NAS as in my essay 
"Comments on the Meaning of Membership in the NAS."

To the extent you have concerns about the conclusions of the Richards Panel, it is up to you to ask the NAS directly for such an investigation instead of complaining to me about a panel nominated by the NAS at the request of NIH-HHS, while you merely put NAS President Frank Press on your cc list.

\section{Part III. Misrepresentations by you concerning your handling of the French virus}

Parts I and II already document among other things the extent to which statements you make are not reliable. I have dealt so far with your statements as they pertain to various officials. Concernng your handling of the French virus, you mix statements about me with statements which appear to be a defense against long-standing reported allegations concerning your actions. I could deal with these ad nauseam. I shall give only a few significant examples.

§1. A misquotation. You raise the question: "Do you honestly believe I was 'hiding' culturing the 'French' virus when such data is included in these papers only a few months later? This is absurd."

The word "hiding" is yours, not mine. I never used the word "hiding" in commenting on your works, let alone state that I "believe" you were "hiding." Your putting the word "hiding" in quotation marks in a sentence where you ask me whether I believe you were hiding culturing the French virus is a misrepresentation.

\$2. Propagation of the French virus. You write: "As to your other point that in the Popovic et al. paper I denied culturing LAV in a cell line but in fact, we had succeeded in doing so, is a flagrant misrepresentation."

In fact, in the Popovic et al. paper published in Science, 4 May 1984, p. 500, over the names of Popovic, Sarnghadaran, Read, and Gallo, one finds the sentence: "These findings suggest that HTLV-III and LAV may be different. However, it is possible that this is due to insufficient characterization of LAV because the virus has not yet been transmitted to a permanently growing cell line for true isolation and therefore has been difficult to obtain in quantity." Your unqualified assertion that "the virus has not yet 
been transmitted to a permanently growing cell line for true isolation" was one of the principal foci of the OSI investigation.

Furthermore, the point you mention was not made by me. More accurately, in my letter to all NAS Section Chairs dated 1 September 1992, I quoted the Richards Panel Report correctly: “... they denied propagation of the French virus and stated (in the Popovic et al. manuscript) that the French virus had never been transmitted to a permanent cell line. Given the quality of the information derived from propagation of the French virus, we believe this constitutes intellectual recklessness of a high degree-in essence, intellectual appropriation of the French viral isolate." I reproduced the quote to compare what the Richards Panel had written with what NIH Director Healy wrote to James Mason, as factual evidence of the way she misrepresented what "the consultants" (her expression) had reported to her. Many publications have reproduced similar quotes from the Richards Panel Report (Science, Chicago Tribune, etc.).

I shall now go into greater details about some of your own actions and statements in the past, concerning the growth of the French virus.

\section{Your annotations or comments on a manuscript}

by Popovic. In your letter to me, right after your sentence about my references to you being "deeply disturbing and shocking," you write: "What you have not perceived in any of your harangues is what I meant by the question "are you crazy" and the comment "this is incredible," which I marked in Popovic's first manuscript."

What prompts you to bring up your annotations on Popovic's manuscript is not clear, since I have never commented directly on these annotations, although they have been mentioned in the press. For instance, they were mentioned in Crewdson's article "Scientific panel accuses Gallo of 'recklessness"' (Chicago Tribune, 27 March 1992), and I reproduced some paragraphs from Crewdson's article in my letter to the NAS Council dated 5 April 1992. Since you have now brought up the comments you wrote on Popovic's manuscript, I shall deal with them and I shall set some of the record straight.

(a) What you wrote in the margin, opposite two of Popovic's statements about LAV, were the assertions: "Mika you are crazy" and later in the paper "I just don't believe it. You are absolutely incredible." In your letter to me, you fail to mention the context of these comments as follows:

(b) You fail to mention that opposite your "Mika you are crazy" 
annotation, you struck out Popovic's statement that "LAV as a reference virus (gift from Dr. L. Montagnier) had been used in the first series of experiments."

(c) You fail to mention that opposite your "I just don't believe it. You are absolutely incredible." annotation, you struck out Popovic's statement that LAV "is described here as HTLV-III." According to Crewdson's article "U.S. probe cites lies, errors in AIDS article" (Chicago Tribune, 15 September 1991):

After excising Popovic's acknowledgments Gallo added a statement of his own, one that was less detailed but that nevertheless disclosed that Popovic had successfully grown the French virus.

However, Gallo later deleted that acknowledgment as well, the [OSI Draft] report said, and added the assertion that his AIDS virus and the one from France "may be different" viruses.

The final draft of the article contained no indication that the French virus had ever been present in the Gallo lab.

(d) In your letter to me, you write: "As a group, we discussed an alternative which I believe was quite honorable." On the other hand, available evidence (some of which is summarized below) is "at odds" with your statement, according to the OSI Draft Report.

The record shows that Popovic expressed serious concerns about your deletions of the sentences giving credit to the French, and told the OSI investigators that he disagreed with your decision to change the article. According to Crewdson (loc. cit.), the OSI Draft Report quotes Popovic as follows: "I told him [Gallo], and I am telling him now, was that it would be better, we should refer to the French what we had." In a later, written submission to the investigators, Popovic was even more explicit: "I did not agree with Dr. Gallo that the references to the work we did with the French virus should be omitted or even significantly minimized. I thought it was wrong not to credit Dr. Montagnier's group's contributions more clearly." Crewdson further writes:

Gallo disputed the assertion that Popovic had argued for further disclosure, saying he recalled only "a very brief discussion" in which Popovic had mentioned the subject "in an almost casual way."

The NIH Report notes, however, that Gallo's recollections appeared "at odds" with the fact that Popovic secreted some of the draft manuscripts in Eastern Europe "specifically be- 
cause of his concerns about what he viewed as a failure to adequately report the work on LAV."

... Popovic told the investigators he had kept the edited manuscripts partly because of "his concerns about the loss of control over the preparation and editing of the paper." Another reason, Popovic said, was that he "believed that some time in the future I might need them as evidence to prove that I gave fair credit to Dr. Montagnier's group."

Thus did Popovic express on the record, in a serious way and not "in an almost casual way," his concerns about your excision of the material giving credit to Montagnier's group.

\section{\$4. Alleged difficulty of growing LAV. After mentioning} your annotations on the Popovic manuscript, you continue with itemized points about your handling of the French virus, and about the conclusions given in the OSI Report and the Richards Panel Report. I shall summarize some facts concerning some of those points, and the way they were evaluated by the OSI investigating team.

You write: "You and Dr. Richards know none of the background, none of the reasons, none of the purposes of those remarks," referring here to your annotations on the Popovic manuscript. You then claim to give "an outline fragmentary explanation" for these remarks, of which the first two points are:

(1) I had little idea of how much or long Popovic cultured $\mathrm{LAV}$. Indeed, he always indicated to me it was very short term.

(2) Indeed, LAV grew only with great difficulty.... The true LAV could only be grown with great difficulty. That is true today. Indeed, the Pasteur group had said it was impossible to grow LAI in a cell line.

The OSI investigators found such claims "difficult to credit," as reported by Crewdson (loc. cit.):

Gallo said the assertion he added to the article-that the French virus had "not yet" been successfully grown-had merely reflected his impression that the Pasteur scientists had been unable to grow the virus they had discovered, a crucial step in preparing it for scientific studies.

The investigators said they found it "difficult to credit" Gallo's explanation, particularly in view of his admission 
that he had also deleted from the manuscript the acknowledgment that the French virus had grown successfully in Gallo's lab.

You give no documentation for attributing to the Pasteur group that they said "it was impossible to grow LAI in a cell line," and your claim is contradicted not only by what Montagnier has said and still says, but by you in your own press conference of 23 April 1984, when you said:

They didn't have enough material to send to us. That's what's been the delay. They don't have a mass producer. As of a few weeks ago, they didn't have it successful in a cell line. I talked to Chermann and Montagnier today and two weeks ago. They believe they're getting it into a cell line just now.

Thus in a press conference in April 1984, you acknowledged learning that the French group were growing the virus in a cell line. Crewdson correctly reported these events (loc. cit.):

Gallo also said he had been trying to spare the Pasteur scientists embarrassment. To have reported that Popovic had grown the French virus, Gallo said, "would then almost be making fun of their oft-quoted statement that it couldn't be done."

The Pasteur researchers never made any such statements, however. In February of 1984, the month Popovic achieved his first continuous AIDS virus culture, Pasteur scientists accomplished the same feat-something Montagnier says he told Gallo a month before the Science article was published.

Your claim that you meant to refer only to the alleged failure of the Pasteur group to grow LAV is incompatible with a number of statements you yourself made before and after publication of the Popovic et al. paper, to the effect that neither you nor anyone else had been able to grow LAV. Statements by you to this effect were made in a 1984 letter to the editor of a British medical journal, reported by Crewdson (loc. cit.), and are also reported in publications as diverse as Science, the Wall Street Journal, and U.S. News and World Report during $1985 .^{3}$ For example, the latter

3 I quote from these publications, putting statements attributed to you 
in boldface italic.

- John Crewdson, "U.S. probe cites lies, errors in AIDS article," Chicago Tribune, 15 September 1991: In March of 1984-five months after Gallo's lab began growing, photographing and testing the French virus, and two months before the Science article was published-Gallo wrote the editor of a British medical journal [Ian Monroe] that the French virus had "never been characterized nor transmitted permanently into recipient target cells." "Therefore," Gallo declared in the letter, "no one has been able to work with their particles, and because of the lack of permanent production and characterization it is hard to say they are really 'isolated' in the sense that virologists use this term."

- Colin Norman, "AIDS Virology: A Battle on Many Fronts," Science, 1 November 1985: Montagnier sent a second sample of supernatant on 23 September [1983]. This time there was detectable reverse transcriptase activity and Popovic transiently infected some fresh lymphocytes with the virus. According to Gallo, the reverse transcriptase activity was very low, and they could not get continuous virus production, so they put the material in the freezer.

- Colin Norman, "Patent Dispute Divides AIDS Researchers," Science, 8 November 1985: The Pasteur memo notes that when the precise genetic sequences of HTLV-III and LAV were determined early this year, the two were remarkably similar.... By implication, the memorandum suggest that Gallo's group somehow grew the French isolate. "The Institut Pasteur can establish a prima facie case of breach of contract in that the retrovirus given to [Gall's group] or one derived therefrom to the best of Institut Pasteur's knowledge, was used in contravention of the terms of the letter agreement," which restricted use of the isolate to research purposes, the memo states.

Gallo indignantly disputes this allegation on several counts, including the fact that the viruses are not identical and that the amount of virus Montagnier sent would not have been sufficient to infect a cell line (see box on page 643).

... [From the box on page 643] Gallo and Popovic say they infected fresh lymphocytes with the virus Montagnier sent, but when the reverse transcriptase activity declined they put the material in the freezer.

- Marilyn Chase, "French Scientists Sue U.S. on AIDS Research Royalties," Wall Street Journal, 16 December 1985: In effect the French and their supporters suggest that Dr. Gallo misappropriated the French virus and presented it in his work, which was later patented. Dr. Gallo refutes this, saying that the LAV and HTLV-III strains, although related, aren't identical, differing by $2 \%$ of their genetic building blocks. Besides, the single LAV sample was too small to be of practical use, he argues....

- Joseph Carey, "The Rivalry to defeat AIDS," U.S. News and World Report, 13 January 1986: The genetic make-up of all known AIDS vi- 
quotes you as saying: "It was physically impossible to grow the particular virus sent by Montagnier."

Subsequently, in 1986, following the public revelation that you had published electron micrographs of LAV identified as HTLVIII, ${ }^{4}$ you moved away from unqualified statements that LAV could not be grown in a cell line, but you claimed that the growth of LAV was never more than "temporary" or "transient." You repeat this claim in your letter to me, when you write: "... Obviously, I was referring to the French group, not to what we had recently (and in my thoughts quite transiently) succeeded in doing." Your claim of "transient" growth, referring to what you and your laboratory were doing, was reported in various publications, including Nature and the New York Times. 5

This further claim itself turned out to be questionable, and according to the OSI Draft Report, it is not valid. The OSI Draft Report concluded that your growth of LAV was far more than "temporary" or "transient." Indeed, the OSI Draft Report also de-

ruses generally varies as much as 10 percent, but those identified by Montagnier and Gallo differ by only 2 percent. For that reason, some experts have speculated that Gallo may have mistakenly contaminated his experiments with the French virus.

"That's the height of outrage," responds Gallo, who adds that "it was physically impossible to grow the particular virus sent by Montagnier."

4 According to Tim Beardsley's article "French Virus in the Picture," Nature, 17 April 1986: "The error can only be described as acutely embarrassing."

5 I quote from these publications.

- Robert Waldgate and Tim Beardsley, "Pasteur plans to pursue patent suit on virus," Nature, 3 March 1986: He [Gallo] achieved transient growth (evidenced by the electron microscope observations and reverse transcriptase activity) of the LAV sample supplied by Montagnier in a HUD-78 cell line, but for one week only and in small quantity: subsequent tests showed no evidence of viral duplication. Attempts to grow LAV in the high-yielding $\mathrm{H9}$ cell line were totally unsuccessful.

- Erik Eckholm, "Wrong Virus Picture Used in 1984 AIDS Article," New York Times, 12 April 1986: Dr. Gallo said that in September 1983 the Pasteur Institute had sent his laboratory "a small amount of fluid" containing LAV, the qualities of which were still uncertain for research purposes. At that time he said his group was also zeroing in on a possible viral cause of AIDS....

Yesterday, Dr. Gallo said that his lab had been able to infect human cells with the virus sample received from France only "transiently." 
termined that LAV actually was the first isolate of the AIDS virus that you were able to grow in a permanent cell line. According to Crewdson's summary of the OSI Draft Report (loc. cit.):

Gallo has long maintained he had many isolates of the AIDS virus in his laboratory. But the investigation has determined that the virus that grew earliest, and best, was the one he got from France.

Gallo told the investigators he had not intended to conceal from readers of the Science article the fact that the virus the French called LAV had been successfully grown in his own lab.

... In late 1986, at the height of the U.S. government legal battle with the French, Gallo maintained under oath that Popovic had succeeded only "temporarily" in growing the French virus.

The report points out, however, that "it was only Dr. Gallo's orders to Dr. Popovic, not the difficulty of maintaining the cultures," that ended the Gallo laboratory's experiments with the French virus.

Finally I shall conclude my documentation by citing a memo of June 1991 by Suzanne Hadley, Chief Investigator in the Gallo case at the time. This memo was first disclosed by Crewdson in the Chicago Tribune, and then Science obtained a copy, as David Hamilton states in his article "Hints Emerge From the Gallo Probe," Science, 16 August 1991. In this article, Hamilton described some of the content of the memo as follows:

Written in early June, the memo lays out numerous contradictions between official statements in patent filings and legal declarations and the findings of the OSI investigation. While one NIH source sympathetic to Gallo insists that "the patent is solid" despite the OSI findings, other sources point out that willful false statements in a patent application can be grounds for invalidating the patent.

Perhaps the biggest surprise in Hadley's memo is the news that the first virus Gallo's laboratory managed to grow in a continuous cell culture was none other than LAV-an isolate supplied by the Pasteur Institute. Gallo's declaration states that while Popovic did attempt to infect two cell lines with LAV in mid-October 1983-at least a month before establishing the cell line that produced HTLV-IIIB-"both transmissions were only temporary in nature." Hadley, 
however, notes in her memo that LAV continued to grow in Gallo's laboratory until Gallo ordered Popovic to freeze the cultures away in January 1984. These transmissions of LAV 'were no more 'temporary' or transient than HTLV-IIIB, which was nurtured with fresh cells as well as virus to keep it alive," Hadley wrote.

In fact, since Hadley wrote this memo, the sequencing analysis (to which I refer in Part I, \$1) determined that HTLV-IIIB and LAV are one and the same. With this remark, I conclude the first three parts of my answer to you, documenting invalid points, misrepresentations of the record, and numerous inaccuracies, as I asserted at the beginning of this letter.

\section{Part IV. Responsibilities}

You raise questions of responsibility when you write: "If you would like a fuller understanding of these issues, I would be pleased to review with you and to document these events."

It is not my responsibility to "review with you," especially under the circumstances improperly created by NIH, HHS, and the NASnominated Richards Panel.

\section{\$1. It is for officials of NIH and HHS, for the NAS- nominated Richards Panel which was to "oversee" the OSI investigation, and for the NAS itself, to issue} credible reports based on facts, on documentation, and on direct exchanges between you and the Richards Panel, if necessary. It is for officials of these organizations to be answerable to the scientific community for their reports. It is not my responsibility to provide the opportunity for an exchange between you and the Richards Panel, but it was Healy's responsibility to do so, if necessary. Instead she bypassed the Richards Panel with her "own committee of advisers," she undermined the Richards Panel in the media, and she muzzled the Richards Panel with a "Confidentiality Agreement," which the panel unfortunately accepted. As a result, the Richards Panel feels it cannot answer questions from the scientific community, and thereby fails in its responsibility toward the scientific community. It was also Healy's responsibility to inform the scientific community properly of the results of such an exchange, if necessary, instead of making tendentious leaks to the Washington Post. 
\$2. It is for HHS to release the OSI Report officially, or possibly a corrected version of it because of the serious criticisms which have been made of this report. As I told you on the phone when you called me on 12 May 1992, I await the official final version. So far, OSI, NIH, and HHS have not met their responsibility properly, in several ways which I documented in my mailing of 1 September. It is not for me to substitute for their defective operation, or to reproduce the 50 pages of this mailing here. I stand by what I wrote in my mailings.

\$3. It is for you to address your complaints to the Richards Panel directly and publicly on the record through official channels (NIH, HHS, and NAS). It is for the Richards Panel to answer publicly on the record, whatever complaints you have concerning their report.

\section{Part V. Answering your letter and phone conversations}

You write: "I hope you will be consistent in your views that people properly answer their letters and answer this letter, and I hope it is not in the way of avoiding an answer by stating you stand on your opinion' as you told me by telephone."

\$1. Misquotation. The quote which you attribute to me ("you stand on your opinion") is a misquotation. That is not what I told you on the phone when you called me on 12 May 1992. I told you that I stand by what I have written. I repeat this statement now for the nth time. What I have written includes extensive documentation and primary sources. Since you are misquoting a statement I made over the phone, and you have sent your misquotation to a cc list, I would appreciate your not calling me again because you cannot be relied upon to report my statements accurately. I trust you will correct your misquotation to each person on your cc list, and to others to whom you may have shown your letter to me. 
52. Pop psychology. Your letter contains a number of phrases and sentences engaging in pop psychology, such as:

“... Instead, you are hèlping forces of repression, greed, hatred, jealousy, and ignorance."

"... You are also wrong and mean spirited...."

“... With this in mind, don't you believe you are unfair to me, when instead you could be helpful? I realize that may be asking you to have the courage to change your direction in a way that may be against your nature. I hope you will."

I do not deal with pop psychology about "greed," "hatred," "jealousy," being "mean-spirited," people's "nature" and "courage." I deal with documentation and the processing of information-or disinformation. I stand by my mailings, in which I provide extensive information and documentation for my assertions.

§3. Misinterpretation. I object to your interpreting my standing by dozens of pages of documentation as "avoiding an answer." I do not give answers in slivers, or by misquoting and misrepresenting others; I also want to avoid being misquoted by others, but I didn't succeed with you.

84. Answering on the phone. A phone conversation is not the occasion to respond with documentation to statements you make on the phone. Richards made a similar point in his letter to Healy (12 May 1992) when he wrote about his phone conversation with you after you called him up: "In our phone conversation, I specifically stated that the Comments [of the Richards Panel] were based on the written report from OSI, and that, if there were relevant errors of omission or commission in that report, some of the Comments might be reexamined by the panel, but a single hurried phone conversation with Dr. Gallo is not an adequate basis for reconsideration." Richards' letter to Healy was among the enclosures of my mailing of 1 September. I stand by my mailings.

\section{Serge Lang}

PS. You are entitled to be represented by your own words, and I want people to be able to verify what you actually wrote. Hence I enclose your letter to me in the present mailing.

cc: Fred Richards, Frank Press, Council of the NAS, all Section 
Chairs and Class Officers of the NAS, Louis Sullivan, James Mason, Bernadine Healy, John Dingell, Suzanne Hadley, and the rest of the cc list. 


\section{A LETTER TO LEADERS OF SCIENCE}

Following the exchange with Gallo, I wrote on 30 November 1992 to leaders in science, pointing to what I regarded as a scandalous situation created by the NIH reports. Allan Bromley at the time was Presidential Science Advisor, on leave from Yale.

To: Allan Bromley

Louis Sullivan, Secretary HHS

James Mason, Assistant Secretary HHS

Bernadine Healy, Director, NIH

The Council, National Academy of Sciences

Frank Press, President, National Academy of Sciences and others

1. The handling of the Gallo case (among others) by the leaders of science has been a profound mess. The leaders' failures of responsibility force individuals either to accept that things are going to get worse before they get better, or to spend an inordinate amount of time and effort documenting these failures and attempting to deal with them. Expanding such time and effort detracts from doing science.

2. I enclose a letter which Gallo wrote to me. In reviewing the evidence to write my reply, and especially reviewing the OSI Draft Report of June 1991 and the OSI Report of March 1992 as reported in the media, I was struck by an aspect of these reports, namely:

(a) The OSI Reports, supported by the NIH scientific advisers, found that Gallo and his lab engaged in a number of practices, specifically: "lack of laboratory records ... lack of attention to details which resulted in false representation ... lack of scientific rigor ... breached overall responsibility ... to ensure the accuracy of the paper ... created and fostered conditions that give rise to falsified/fabricated data and falsi- 
fied scientific reports...."

(b) At the same time, the OSI investigators and two out of three NIH scientific advisers (other than the Richards Panel) declared that there was no "misconduct" on Gallo's part, in the technical sense defined by the Public Health Service, namely "other practices that seriously deviate from those that are commonly accepted within the scientific community for proposing, conducting, or reporting research." However, the OSI investigators and all three NIH scientific advisers judged that these practices "merit significant censure" in the conclusions of the OSI Draft Report.

Therefore, a remarkable conclusion follows from the logic of the OSI investigators and the two NIH scientific advisers, to wit: a number of practices which merit "significant censure" in the OSI Draft Report, and are listed above in boldface italic, do not seriously deviate from those that are commonly accepted within the scientific community. Since the "significant censure" was deleted from the OSI Report of March 1992, one can further conclude that according to revised and more current views, these practices, which do not seriously deviate from those commonly accepted within the scientific community, also do not merit "significant censure."

3. Instead of actively doing something about this situation, which I regard as scandalous, the leaders of science are continuously engaged in obfuscations and evasions of responsibility. I conclude that the failure of the scientific community's leadership, whether in government agencies such as NIH and HHS, or the NAS, has been monumental. You are in a position to make a difference. I challenge you to do so. 


\section{A REPORT BY THE HHS OFFICE OF RESEARCH INTEGRITY (ORI)}

\section{\$1. Conclusions of the ORI Report}

The HHS Office of Research Integrity (ORI) on 30 December 1992 issued a report which agreed with some findings and reversed other findings of the OSI Report and NIH Director Healy.

In Crewdson's articles, he did not make allegations. He reported factually, but the facts raised questions and issues perceived in various ways by different people. At the end, the ORI Report lists several conclusions concerning some of the issues raised by Crewdson's reporting, and asserts (pp. 52-53): "ORI concurs with the OSI finding that Dr. Gallo did not commit scientific misconduct in relation to the several issues in the Chicago Tribune article, and the noted discrepancies or issues raised by the 1984 Popovic paper (with the exception of the statement that LAV had not been put in a permanent cell line, discussed in the preceding section). However, ORI believes that many of Dr. Gallo's actions reflect a pattern of conduct that must be censured even though they do not constitute scientific misconduct." The ORI Report goes on to list four items (p. 53) which they judge deserving "censure." ${ }^{1}$ The first item concerns the role played by Gallo as a

1 The four counts I have quoted from the ORI Report were well summarized systematically at the end of the article:

"Federal Inquiry Finds Misconduct By a Discoverer of the AIDS Virus," New York Times, 31 December 1992, p. Al.

The ORI Report received extensive coverage in the press. I list a few more articles here:

"New HHS Report Faults AIDS Researcher," Washington Post, 31 December 1992, p., A4.

"U.S.: Top AIDS scientist guilty of misconduct", Chicago Tribune, 31 December 1992, p. 1.

"Righting the record on AIDS research," editorial, Chicago Tribune, 31 December 1992.

"HHS: Gallo Guilty of Misconduct," Science, 8 January 1993, p. 168.

"US report finds NIH's Gallo guilty of misstatement," Nature, 7 January 1993, pp. 3, 4.

"Gallo on the rack-The latest government pronouncement raises 
reader-referee for a scientific article submitted by French scientists from the Institut Pasteur, including Montagnier (head of the laboratory), and Françoise Barre-Sinoussi (one of the principal researchers), whose name appeared first on the paper. This first item listed states:

- Dr. Gallo's role in the Barre-Sinoussi paper: OSI found that Dr. Gallo's actions were "gratuitous, self-serving, and improper." It was the admission by Dr. Montagnier that he may have seen the galley proofs for the article, and did not raise any objections to the material added by Dr. Gallo, that led ORI to conclude that Dr. Gallo's actions did not constitute scientific misconduct. Nonetheless, ORI believes that Dr. Gallo's actions reflect Dr. Gallo's propensity to misrepresent and mislead in favor of his own research findings or hypotheses.

The other three items read as follows ("LTCB" refers to Gallo's laboratory, Laboratory of Tumor Cell Biology).

- Dr. Gallo's failure to fulfill his obligations as the senior author: In light of his role as senior author of the Popovic paper, Dr. Gallo must bear substantial responsibility for the numerous discrepancies in the Popovic paper, including the four instances of scientific misconduct attributed to Dr. Popovic. The scientific and public health importance of the research undertaken in the LTCB imposed an obligation for accuracy in reporting the methodologies and results of this groundbreaking research-an obligation that Dr. Gallo failed to meet.

- Supervision of the LTCB by Dr. Gallo: Especially in light of the groundbreaking nature of this research and its profound public health implications, ORI believes that the careless and unacceptable keeping of research records revealed by the OSI inquiry and investigation reflects irresponsible laboratory management that has permanently impaired the ability to trace the important steps taken.

- Failure to determine the source of [the cell line] $\mathrm{H}^{2}$ in a timely manner, and restrictive conditions on access of other researchers to H9: Dr. Gallo's failure to determine in a

questions about the office itself as well as about Gallo," editorial in Nature, 7 January 1993, p. 1.

2 The cell line H9 was "the permanent cell line in which HTLV-III grew," according to the ORI Report, p. 51. 
timely manner the derivation of the cell line that supported the HTLV-IIIB culture and the imposition of restrictive conditions on its distribution reflect Dr. Gallo's indifference to acknowledging promptly the contributions of others and to sharing of research materials of critical public health importance.

These conclusions were followed by two summary paragraphs (p. 54), concerning broader implications of Gallo's scientific practices. I reproduce these paragraphs in full:

Overall, ORI finds that the events surrounding the discovery of the AIDS virus and the development of a blood test are highly regrettable and unfortunate. The scientific trail of evidence for findings of such profound public health importance is so muddled that the source of a critical cell line remained uncertain until well after publication of the Popovic paper, and the source of a critical viral isolate (MOV) remains unknown. A disregard for proper scientific recordkeeping in groundbreaking research played a major role in this failure.

Furthermore, a failure to fully disclose all aspects of the research, and a propensity to exaggerate LTCB accomplishments, undermine the legitimate and important accomplishments of Dr. Gallo and Dr. Popovic. ORI believes that Dr. Gallo and his research team were instrumental in identifying the AIDS virus and protecting the blood supply from contamination with the virus. To have these critical accomplishments diminished by the actions documented in this investigation is a tragedy for science, and for Drs. Gallo and Popovic.

The ORI Report made a distinction between certain issues on which Gallo should receive "censure" as in the above four counts, and another on which Gallo was guilty of "scientific misconduct," as we shall discuss below. This distinction was to haunt ORI in its dealings with the HHS Appeals Board later. Compare with the "Offer of Proof" to the Appeals Board, excerpts from which are reproduced in Appendix 3 of the next part. In this "Offer of Proof," ORI attempted to tighten and upgrade its evaluation from "censure" to "misconduct," and generally used stronger language.

Aside from being aware of items giving general conclusions such as those listed above, I think it may be useful for readers also to be aware more specifically of the way the ORI Report analyzed some of the points of contention. The French virus called 
LAV was at the center of attention, because of the possibility that it was misappropriated by Gallo. Especially, a question was raised as to the relation between the virus HTLV-IIIB alleged by Gallo to have been grown in his laboratory, and the French virus LAV. Gallo with several coauthors, notably Popovic, after whom the article is named, had published an article in Science, in which they claimed to have discovered a method to grow the AIDS virus continuously in a cell line. ${ }^{3}$

The misappropriation issue. The ORI Report describes the first of its specific concerns as follows (p. 11):

(1) Did HTLV-IIIB's affinity to LAV reflect a misappropriation of LAV or an accidental contamination of the "pool" culture? A corollary issue was whether the LTCB had other HIV isolates available that could have been used to develop the AIDS blood test on approximately the same timeline as development of the test with HTLV-IIIB.

On this first issue, after reviewing evidence, the ORI came to the conclusion (p. 28): "ORI supports the OSI finding that it is not possible to resolve the question of misappropriation versus contamination."

A questionable statement concerning LAV. The second main issue of concern to ORI concerned a statement which Gallo had written in the article: 4

These findings suggest that HTLV-III and LAV may be different. However, it is possible that this is due to insufficient characterization of LAV because the virus has not been transmitted to a permanently growing cell line for true isolation and therefore has been difficult to obtain in quantity.

3 The article is entitled "Detection, isolation, and continuous production of cytopathic retroviruses (HTLV-III) from patients with AIDS and preAIDS," by Mikulas Popovic, M. G. Sarnghadaran, Elizabeth Read, and Robert C. Gallo. This publication is referred to through the ORI Report as "the Popovic paper."

4 Despite the fact that there were several coauthors, the ORI Report states (p. 46): “ORI finds Dr. Gallo wrote the disputed statement and is responsible for the concomitant scientific misconduct." 
The ORI concern was then expressed as follows (p. 12):

(2) Was the statement in the Popovic paper that LAV had not been transmitted to a permanently growing cell line a falsification of the status of LAV research?

The ORI Report asserts (p. 29): "The underlined statement is a misrepresentation. LAV had been transmitted to a permanently growing cell line within the LTCB by the authors of this statement. After reviewing the available evidence, OSI found that LAV had been grown in a permanent cell line in the LTCB several months prior to the writing of that statement. Dr. Gallo asserted that the clause, "because the virus has not been transmitted to a permanently growing cell line," was not false because it did not refer to the accomplishments of the LTCB, but referred to the accomplishments of the French researchers. Dr. Gallo alleged that when the statement was written, the French had not grown LAV in a permanent cell line. The OSI experts could not agree on the proper interpretation of the clause; some believed that it referred solely to the French, others believed that it indicated that no laboratory had grown LAV in a permanent cell line. OSI found that the statement was a misrepresentation but did not find Dr. Gallo guilty of scientific misconduct stemming from this allegation...."

However, ORI came to a different conclusion from OSI since its report asserts (p. 43): "In sum, ORI finds that Dr. Gallo falsely reported the status of LAV research when he wrote the statement, and this constitutes scientific misconduct. The explanations that Dr. Gallo proferred for the statement are neither credible when the evidence is considered, nor do they vitiate the impropriety of falsely reporting the status of LAV research in the Popovic paper. Even if the statement can be technically interpreted to refer to the accomplishments of French researchers, an interpretation that ORI disputes, ORI believes that Dr. Gallo is guilty of misconduct because the statement is intended to mislead the research community with respect to the ability of LAV to be grown in a permanent cell line and, thus, constituted falsification in reporting research."

In this evaluation, the ORI came to the same conclusion as the Richards Panel, which they quote in the report (p. 50): "The statement that LAV had not been transmitted in a permanent cell line is simply false, and was known to be false at the time the paper was written. This is one of the most glaring faults in the paper and is part of the pattern of misrepresentation in the discussion 
of the problem of continuous culture. There is no way in which Dr. Gallo can be excused from sharing the blame for this misstatement."

Not all scientists shared the point of view of ORI or of the Richards Panel. For an example, I quote from Science (8 January 1993, p. 170):

In spite of such protestations [by Gallo's lawyer against the ORI Report], even some of Gallo's allies aren't buying the line that he did nothing wrong. Nobel Prize-winning retrovirologist Howard Temin of the University of Wisconsin concedes Gallo was wrong not to describe the lab's use of LAV. "That's clearly improper;" says Temin. He also calls Gallo's reasons for not describing that work in the paper "obviously silly" and says ORI was "quite right to reject them."

Still, says Temin, the ORI Report comes to a "very unfortunate" conclusion because Gallo's behavior, though not collegial, was not misconduct. Temin says he believes misconduct applies to researchers who have falsified "a major thing." In the Gallo case, the misrepresentations were "minor things" says Temin-things that did not affect the paper's conclusions. Temin argues that Gallo's transgressions were a matter of denying credit to a competitor-not serious falsification. Temin also strongly objects to ORI's conclusion that Gallo's failure to describe having cultured LAV impeded other researchers. "LAV and IIIB are the same," he says. Whether researchers got their samples "from Gallo or Montagnier couldn't have made any difference in the world." 


\section{\$2. A Statement by Gallo}

The findings of HHS were reported at length in the press, and notably in Crewdson's article "U.S.: Top AIDS scientist guilty of misconduct" in the Chicago Tribune of 31 December 1992. The article was accompanied by a Gallo statement, which deserves to be reproduced here in full:

After reviewing everything I and my colleagues have ever published on the discovery of the AIDS virus and the development of the AIDS blood test, ORI could only take issue with a few trivial mistakes and a single sentence written by me.

The new and extraordinary finding that the sentence I wrote is false is utterly unwarranted. It is based on a distorted interpretation of the sentence. Numerous NIH scientists believe the sentence means what I intended for it to say, as did the co-authors of the article and previous OSI scientific reviewers.

For the record, I intend to appeal this finding in the ORI Report and expect to have the finding overturned.

On a broader level, this endless and incompetent government investigation should be of concern to everyone seeking to advance medical knowledge. My laboratory's contributions to the advancement of medical science are undisputed. For the past three years, however, I have spent a substantial amount of my time responding to issues involving the OSI and ORI investigations. These investigations have diverted not only my personal time and the time of others in my laboratory, but, perhaps most importantly, our collective creative thinking. We cannot recapture that time. We cannot even begin to calculate the amount of potentially lifesaving research that has been lost. Those who seek to perpetuate investigations that result in petty and misguided conclusions like those in the ORI Report must account for this lost research. They must understand that, while the uncovering of genuine scientific misconduct is important, the mindless pursuit of fantasized misconduct can have devastating consequences for scientific research.

The misguided finding of the ORI Report have no bearing on the validity and importance of the research on AIDS conducted by my laboratory. My intention, while the appeal is pending, is to continue to conduct research on AIDS, cancer, and other diseases. Looking toward the future will be much more productive than reviewing the past. 


\section{§3. "Misconduct" but Ignoring "Significant" Documents}

Although the ORI Report officially used the key word "misconduct," with obvious effects on the public relations platform, it was still defective in not taking into account, let alone releasing, "significant" documents from the NIH files.

There was some evidence that the ORI Report, despite concluding "misconduct" on Gallo's part in one instance, nevertheless still did not contain a substantial amount of information which was withheld in the previous NIH Report of March 1992.

Lyle Bivens, Director of ORI, had the courtesy to send me directly a copy of the report, and I then replied with a letter dated 13 January 1993, formulating criticisms of this report as follows:

Significance of the sequencing analysis. The sequencing analysis and its conclusion that "MOV and HTLV-IIIB were identical to LAV-LAI" are mentioned only once in the ORI Report (one line, p. 13). Everywhere else in the ORI Report, the significance of this finding, even its existence, is ignored. I shall list several examples.

(a) Contamination. On page 27, the ORI Report states that "ORI concludes conditions in the LTCB may have created an environment that resulted in LAV/LAI's contamination of other cultures. The ORI Report further concludes that the contamination could have occurred between late October 1983, when the September LAV samples were taken from the freezer, and late February 1984, when HTLV-IIIB infected the H9 cell line." On page 28, the ORI Report states: "ORI supports the OSI finding that it is not possible to resolve the question of misappropriation versus contamination."

The ORI Report is misleading. Indeed, LAV/LAI is one and the same as HTLV-IIIB according to the sequencing analysis. The ORI Report gives no evidence why it supports the finding of OSI that it is not possible to resolve the question of misappropriation; worse, it gives no evidence that ORI even attempted seriously to probe into that question.

(b) A single isolate. The ORI Report repeatedly has sentences to the effect that HTLV-IIIB and LAV are different isolates. For example, on page 45, the ORI Report states: "ORI notes that Dr. Gallo's failure to reveal the utility of LAV effectively ensured that 
most researchers would use HTLV-IIIB in AIDS research because they would have thought it to be the only HIV isolate grown in a permanent cell line. Consequently, this virtually ensured HTLVIIIB's preeminence in AIDS research." Again on page 52: "In fact, as noted above, revealing that LAV could be grown in a permanent cell line would have indicated LAV's research utility, indicated that HTLV-IIIB was not the only isolate that could be used in the development of an AIDS test, and would have encouraged others to pursue the work with LAV."

Both statements are misleading, because the statements accept that LAV was another isolate, which is not true. The most serious misrepresentation here is that Gallo said repeatedly that HTLV-III was different from LAV, and thereby misled researchers, who were not aware that the isolates were one and the same. ORI fails to even mention this misrepresentation, and thereby contributes to it. See also the next item in the same vein.

(c) Recognition by Gallo-Popovic that LAV is HTLV-II. On page 34, the ORI report quotes an early version of the Popovic manuscript, including one passage which Gallo deleted, but unfortunately the ORI Report fails to quote another even more crucial passage deleted by Gallo, to the effect that LAV "is described here as HTLV-III". This is a serious omission from the ORI Report.

(d) Misreporting of evidence. On page 26, the report states: "The evidence shows that neither Dr. Gallo and his colleagues nor the Pasteur scientists knew before 1991 that LAV/LAI had been present in the LTCB since September 1983."

This sentence is misleading, as shown by the Popovic sentence mentioned in the preceding item, that LAV "is described here as HTLV-III." This sentence dates back to Fall 1983, and shows that Popovic and Gallo did know that LAV had been present in the LTCB in 1983. Gallo and Popovic received several samples of LAV/BRU. One of these samples had unknowingly been contaminated with LAV/LAI at the Institut Pasteur. The fact that Gallo and Popovic were not aware they were working with LAV/LAI is irrelevant, because they were working with LAV/BRU, and they knew it well.

(e) MOV. On page 17 the ORI Report states: "Another isolate, MOV, had been growing in a permanent cell line since November 1983. On 6 January 1984, MOV became the first retrovirus to be used in ELISA tests by Dr. Sarngadharan."

Calling MOV "another isolate" is misleading, because the se- 
quencing analysis found that MOV is LAV. The whole discussion about MOV (pp. 17, 19, 20, 21) ignores this finding, and is therefore misleading. The conclusion that MOV became the first retrovirus to be used in ELISA tests by Dr. Sarngadharan, combined with the fact that MOV is LAV, shows that the French virus was the first one used for their blood test. This conclusion deserved to be stated clearly in those terms in the ORI Report, but it was not so stated.

Withholding of documents. Although the ORI Report corrected some defects and failures of the OSI Report listed in the "Dissent and Critique" of the OSI Report by Suzanne Hadley, nevertheless it perpetuated some of the major flaws of the OSI Report, as exemplified above. The ORI Report was still far from satisfactory, and only represented a second stage in the evolution of the HHS investigative process, after Suzanne Hadley had been dismissed by Bernadine Healy. For a further evolution, readers can see the "Offer of Proof" prepared by ORI for the Appeals Board, even though this "Offer of Proof" was ultimately not used. (See Appendix 3 of the next part.)

Even more seriously, the ORI Report was unsatisfactory because certain crucial documents were still not being mentioned, let alone released. Indeed, the "Dissent and Critique" of the OSI Report reported in Dan Greenberg's Science and Government Report of 1 June 1992, stated:

Material apparently damaging to Gallo, including some of his own testimony, has been deleted. Specious, unsubstantiated arguments adduced by Gallo and his colleague, Mikulas Popovic, have been accepted unquestioningly by OSI. The OSI even constructed its own arguments exculpatory to Gallo.

A number of OSI arguments and conclusions cannot be substantiated; a number are flatly refuted by the evidence. Moreover, in a number of instances, OSI has failed to deal with and even mention highly significant pieces of evidence known to be in its possession. Perhaps most serious, the final OSI Report gives only superficial, misleading consideration to the implications of the highly significant virus sequencing studies. As a result, the OSI has irresponsibly evaded the central question in the entire investigation, the question of Gallo's possible misappropriation of the Institut Pasteur HIV isolate, LAV. 
Even with their ongoing evolution, the ORI Report made no mention that NIH had in its possession additional documents that are "highly significant." These documents were also withheld from the Richards Panel. It was ORI's responsibility to consider these documents, but the ORI Report gives no sign that ORI has taken these documents into consideration. Certainly the ORI Report did not mention these documents, and a fortiori it did not make them available to the scientific community.

\section{\$4. My Conclusions}

As we shall see in connection with an ongoing investigation by the Subcommittee, Dingell has asserted publicly that he was able to obtain documents which NIH systematically tried to withhold, although as late as June 1993, he had not been able to obtain all such documents. (See his public opening statement at the hearings of 21 June 1993, reproduced in its entirety below.) Therefore one can raise the following questions:

1. Concerning HHS and NIH: Did HHS withhold documents from its own Office of Research Integrity? Did NIH withhold such documents? Were higher-ups at HHS (Secretary and Assistant Secretary) aware that such documents were withheld by NIH if they did not withhold such documents themselves?

2. Concerning ORI itself: Was ORI aware that such documents were withheld? If yes, why was such withholding not stated in the ORI Report? If no, what trust can be placed in an office which is so manipulated by others in its own organization?

3. Concerning the scientific community: How can the scientific community rely on official bodies (NIH, HHS-ORI, Richards Panel) to get complete documentation and information concerning the Gallo case?

My answer is that it cannot. Different scientists come to different conclusions, depending on different attributions of importance to different factors.

The scientific community could not rely on the Dingell Subcommittee either, since they never issued a formal report. The next best thing was a Staff Report, prepared with the cooperation of Suzanne Hadley, see below. 


\section{THE HHS APPEALS BOARD}

Various appeals from ORI were considered by the HHS Appeals Board, among which were the appeals by Popovic and Gallo. The ultimate dependency of the NIH and HHS investigations on the Appeals Board finished the long process of eliminating scientists from the review of the Gallo case, and turning it over to lawyers, whose point of view is legalistic, not scientific. Some people have called this "due process." I shall list here some of the conditions imposed by the Board on ORI in July 1993.

\section{§1. Legalistic Rulings}

The Board made legalistic rulings whose effect is to institutionalize certain low standards of behavior and to make it difficult to enforce higher standards of behavior.

(a) The Board found that "anticipatory writing" (claiming that experiments were performed when in fact these experiments were not performed) in an NIH grant application is NOT scientific misconduct. ${ }^{1}$

1 One decision in this respect had to do with the case of Rameshwar Sharma. According to the Washington Post ("U.S. Loses Science Fraud Case on Appeal," 11 August 1993, p. A13): "In an internal investigation, Sharma's employer, the Cleveland Clinic Foundation, found that the scientist had made misstatements but that he had not committed intentional fraud. He had engaged in 'anticipatory writing'-claiming to perform certain experiments that would soon be performed." According to the Washington Post. "ORI proposed disciplinary actions against Sharma that included excluding him from Public Health Service advisory boards for three years and holding any of his applications during that period to a higher standard of review." However, again according to the Washington Post, the appeals panel reported that "we find that ORI failed to carry its burden or proving scientific misconduct by a preponderance of the evidence" and that "ORI's findings are not supported and the proposed administrative actions are not justified." An aide to Dingell is quoted as commenting: "It's a very curious finding. Is this an admission that falsification of a grant application is okay?" 
(b) By a ruling of the Board, ORI must not only prove that scientific misconduct occurred, but ORI must also prove the absence of honest error relative to the alleged misconduct, i.e., ORI must prove a negative.

(c) The Board ruled that falsification, fabrication, and the like are not grounds for a finding of scientific misconduct unless the respondent "reasonably could have anticipated at the time of his alleged conduct that such conduct, if proved, would constitute 'scientific misconduct."'

(d) The Board ruled that scientific misconduct does not include "falsification or any other conduct which does not seriously deviate from commonly accepted practices within the scientific community...." According to the Board's logic, if falsification becomes a universal practice among scientists, then it receives the legal approval of government agencies which are supposed to overview the maintenance of scientific standards for government grants and government laboratories.

Informative analyses of these impositions by the Appeals Board are given in the articles "Hearing Process Proves a Challenge for ORI" (Science, 18 June 1993, p. 1714), and "Case Against Gallo Faces Tough Appeals Process" (Science and Government Report, 15 October 1993). Extensive excerpts from the conditions set by the Appeals Board on ORI will be reproduced in an appendix, so that readers can verify for themselves what ORI was subjected to, especially with respect to what is called an "offer of proof" for ORI's allegations. Among other things, HHS was under the threat of a lawsuit if its ruling did not meet certain legal criteria. Indeed, one of the conditions stated: "If we do not receive such an offer of proof with respect to each allegation, we would dismiss this proceeding with regard to that allegation. To do otherwise would result in this department committing its resources for a proceeding which could not lead to a legally supportable result in ORI's favor."

The focus of the HHS adjudicative process shifted considerations from those of scientific standards to legalistic manipulations. Scientists were not participating.

(a) The Federation of American Societies for Experimental Biology (FASEB) declined an invitation of ORI to participate at the hearing stage, because according to Science (18 June 1993, p. 1714), "the process was more judicial than scientific...," among other reasons.

(b) At first, the Board refused to include a scientist as a member, even though the Board's rules specifically provide for this option, and ORI even requested it. The Board consisted only of 
government attorneys. This same issue of Science also reported the reaction of ORI officials: "ORI director Lyle Bivens acknowledges that the appeals process is not working in the way he envisioned it. Bivens says he hoped that the Board would have included scientists, rather than a solid cast of government attorneys. Indeed, he says, he is 'disappointed' by the failure of ORI's early efforts to get the active participation of the scientific community at the hearing stage, as opposed to during investigations."

The Gallo investigative process started with HHS soliciting the National Academy of Sciences for the nomination of a panel "with a view to ensuring both the fact and appearance of objectivity." As NIH Acting Director William Raub wrote to Fred Richards 16 April 1990: "Throughout, your expertise, independence, and objectivity will be key elements in ensuring a thorough and fair review." Then the NIH-HHS process ran its full course whereby the scientists were manipulated, information was withheld from them, and finally they were completely eliminated and put down at the time the Appeals Board issued certain of its rulings (cf. Appendix 1). ${ }^{2}$

\section{§2. The Popovic Exoneration}

Popovic was the first named author of the Science article under questioning. As summarized in the article "Popovic is Cleared on All Charges; Gallo Case in Doubt" (Science, 262, 12 November 1993, p. 982):

ORI's case against Popovic boiled down to his statement that certain experiments were "not done" when they had in fact been done, ${ }^{3}$ that a " $10 \%$ figure in a table was not supported by data," and that he claimed that certain fluids were "first shown" to contain signs of virus replication before they were mixed together, when that was not the case. The Board noted that none of these alleged misrepresenta-

2 Subsequently, as reported in Science (12 November 1993, p. 982): “If the [Gallo] hearing is held, the Board's three government lawyers will be joined by a scientist, Jules Younger, an emeritus virologist at the University of Pittsburgh. Both sides requested the addition of a scientist as a full voting member of the board."

${ }^{3}$ See below for further comments on this "Not Done" in connection with the Richards testimony; and also Appendix 2 where I quote a more extensive passage from the ORI's comments on the "Not Done" question. 
tions would have made any difference to the conclusions of the paper.

Popovic was completely exonerated by the Appeals Board, which even criticized the ORI by stating: "One might anticipate that from all this evidence, after all the sound and fury, there would be at least a residue of palpable wrongdoing. That is not the case."

Faced with the Popovic verdict, ORI Director Lyle Bivens was quoted in the Chicago Tribune (5 November 1993, p. 18): "My initial reaction is one of outrage. The Board is way off the mark."

Raising new charges. As already documented, the ORI Report did indeed suffer from serious defects.

(a) The defects were partly due to incompetence on several counts, some of which I myself criticized in the manner described previously in Part XI.

(b) A problem arose from ORI having determined that some actions were not "misconduct" but did merit "censure." From the point of view of the Appeals Board, only the legalistic category of "misconduct" had any relevance to their ruling (see for instance the precise quote below).

(c) The defects of the ORI Report were also partly due to NIH withholding from ORI information in the NIH files, as well as ORI's de facto inability to go after this information, or to ask the proper outside sources for this information (e.g. Suzanne Hadley). Bernadine Healy's dismissal of Suzanne Hadley from the investigation had successfully derailed the investigation.

Partly because various sources criticized the ORI Report, and partly because the ORI staff was genuinely trying under difficult circumstances, ORI attempted to improve its case for presentation to the Appeals Board. For instance, it attempted to bring up new evidence, and to upgrade certain actions from meriting censure to actual misconduct. The matter was reported as follows in the article "U.S. may not fight appeal by Gallo" (Chicago Tribune, 10 November 1993, p. 1): "For most of the past year, four ORI lawyers have worked virtually full time in preparing to argue the Gallo case, which is detailed in a 99-page offer of proof, or 'proffer,' they submitted to the Appeals Board last August."4 The

4 Having learned of this "Offer of Proof" from Crewdson (see also Dan Greenberg's "Case Against Gallo Faces Tough Appeals Process"), Science and Government Report, 15 October 1993), I wrote to ORI for a copy, which I received by return mail. I shall reproduce excerpts from this "Offer of Proof" in Appendix 3. Since the document was not mentioned in 
price of getting entangled in legalistic categories became explicitly apparent in the confrontation between ORI and the Appeals Board. The Appeals Board rejected the ORI's attempt to improve the case, and the Appeals Board's decision stated (p. 72):

During the course of the hearing and in post-hearing briefs, ORI attempted to raise other issues concerning the accuracy of the Science paper. We found introduction of these issues to be inappropriate and untimely. In effect, ORI was attempting to reopen allegations of misconduct on which it had not made findings of misconduct in the final report which served as the basis for this proceeding. While ORI attempted to characterize these matters as merely going to Dr. Popovic's credibility, ORI had not even identified these matters as part of the pattern of conduct it said (in the Offer of Proof submitted several weeks prior to the hearing) it would show to prove Dr. Popovic's intent. Thus, Dr. Popovic did not have fair notice that these issues would be addressed, and we ruled that they were outside the scope of this hearing. ${ }^{5}$

The attempt to present an improved case was subsequently described as follows in "The Aftermath of the Gallo Case" (Science, 263, 7 January 1994, p. 22): "In interviews after the Popovic decision, ORI also contended that the Board refused to hear evidence of a 'pattern of behavior' to prove intent in the Popovic case. But Rebecca Dresser, a misconduct expert [sic] at the Case Western Reserve University Law School who examined the Appeals Board decisions at Science's request, says the Board drew the line only when ORI tried to raise a serious charge not in its investigative report."

At the same time, Science did not give any indication to its readers concerning the substance of the issues, listed extensively in the ORI "Offer of Proof." (See Appendix 3.)

magazines such as Science, I distributed 30 copies, and also sent a copy to the Council of the National Academy of Sciences, as well as to Ellis Rubinstein, news editor of Science.

${ }^{5}$ The paragraph continues: "We nonetheless discuss these issues briefly here since ORI continued to press them and since they were raised in a public forum." 


\section{§3. Dropping the Gallo Case; Press Reports}

The Chicago Tribune article of 10 November 1993 (mentioned above, page 10) reported: "ORI officials acknowledged there was nothing to prevent them from opening a new and broader investigation of Gallo based on evidence that has come to their attention since the NIH investigation was concluded. But they admitted that such a decision might cast them as 'zealots who are tormenting this guy."

Given the legalistic conditions imposed by the Appeals Board, their exoneration of Popovic, the apprehension about being cast as "zealots who are tormenting this guy," and a basic disagreement about "standards," ORI dropped all charges against Gallo. ORI Director Lyle Bivens went on the record against the ruling of the Appeals Board (HHS press release dated 12 November 1993). For instance, as reported in the New York Times (listed below) the Office of Research Integrity stated that it was dropping the charges chiefly because the Appeals Board "now applies different standards from those applied by the Office of Research Integrity ... ORI maintains that the standards applied by the panel reflect a fundamental disagreement with ORI as to the importance of clarity, accuracy, and honesty in science. However, because ORI is bound by the panel's decisions, it will not continue its proceeding against Dr. Gallo."

Thus the Appeals Board never issued a decision on Gallo himself. The ORI dropping of charges against Gallo was widely reported in the press. I list a few articles here.

"Misconduct Charges Dropped Against AIDS Virus Scientist," New York Times, 13 November 1993, p. 1.

"Misconduct finding against Gallo dropped," Chicago Tribune, 13 November 1993, p. 1.

"Case against AIDS scientist dropped," Washington Post, 13 November 1993, p. 1.

"Misconduct charges against Gallo withdrawn after Popovic decision," Nature, 18 November 1993, p. 191.

"ORI Drops Gallo Case in Legal Dispute," Science, 19 November 1993, p. 1202.

"Victory at Last for a Besieged Virus Hunter," Time, 22 November 1993, p. 61.

The New York Times and Chicago Tribune articles reported Gallo's statement: "I am delighted that ORI has dismissed the case against me and that I have been completely validated. I will 
now be able to redouble my efforts in the fight against AIDS and cancer. There are several avenues of AIDS research that my laboratory is pursuing."

In addition to these news reports, there were supporting articles and editorial statements, favorable to Gallo, for instance in the Washington Post and New York Times. Gallo himself sent me these pieces (which I already had), accompanied with a note reading: "Dear Dr. Lang, despite your bias, despite your antiscientific self-righteous [sic] and methods, despite your obsessive need to fulfill hate mongering-nonetheless I thought your need 'to be involved' should be fulfilled by sending you information you may have not seen or chose to ignore." I shall quote from both these pieces.

Washington Post editorial: "Dr. Gallo: A Vindication" (1 December 1993). The Washington Post editorial concluded: "Dr. Gallo may not be known for his modesty or retiring nature, but he is, without qualification, a dedicated and accomplished scientist who has been subject to a great deal of personal attack... But it is now clear, even to those who have doubted it for years, that the problem [of eliminating AIDS] will not be solved politically.... It is instead a staggering scientific puzzle whose solution requires the talents and dedication of the nation's best medical researchers. Dr. Gallo and many others at NIH are among them."

New York Times Magazine: "Method and Madness-The Vindication of Robert Gallo," by Nicholas Wade (Sunday, 26 December 1993). The New York Times Magazine piece, by New York Times science editor Nicholas Wade, was even more favorable to Gallo. I quote more extensive excerpts, because I think this piece is very important to document the New York Times' journalism:

For years, Gallo has been under a thick cloud of suspicion that he stole from French scientists the credit for discovering the AIDS virus. The suspicion has proved groundless.

As a Government Appeals Board concluded last month: "One might anticipate that from all this evidence, after all the sound and fury, there would be at least a residue of palpable wrongdoing. This is not the case."

Not even a residue?

No, and in truth, Gallo's achievement was greater than has been generally understood, since it far exceeded the 
mere co-discovery of the AIDS virus with which he is usually credited....

After 12 years, Gallo's blood test is still the only weapon of real value that scientists have yet managed to devise against this baffling disease. But far from basking in gratitude, Gallo has been subjected to years of humiliation. What prompted this cruel twist of fate?

In brief, a scientific puzzle led to a newspaper attack that triggered an insatiable government inquiry. The puzzle was that the version of the AIDS virus Gallo used for his blood test turned out to have almost the same genetic sequence as Montagnier's virus.... One explanation was that the French virus had gotten loose in Gallo's lab and overgrown his own virus cultures.... The other possibility was that Gallo had used the French virus for his experiments without isolating his own, a physical and intellectual theft. Given Gallo's competitive nature and his well-known thirst for recognition, the second possibility loomed large in people's minds.

An unusual piece of reporting gave the suspicion shape. John Crewdson, a Chicago Tribune reporter who won a Pulitzer Prize while with the New York Times, spent 20 months investigating Gallo's work. His 50,000 word article of Nov. 19, 1989, described several cases in which colleagues and others believed Gallo had hogged credit for joint discoveries. Yet the article, despite its author's perseverance, had several defects.

It was relentlessly hostile to Gallo, interpreting one complex event after another to his discredit....

Nonetheless, the Crewdson article prompted an inquiry by a government office now known as the Office of Research Integrity.... But in 1991 Gallo and Montagnier solved the festering mystery. The two scientists' original viruses were indeed different strains, as Gallo had said all along... The only evidence for assuming Gallo had appropriated the French virus promptly evaporated.

But instead of dropping the case, ORI plodded on. It claimed there were misstatements in Gallo's discovery papers, particularly in sections written by his colleague Mikulas Popovic, a Czech virologist. It accused Gallo and Popovic of "scientific misconduct," even while conceding the alleged misstatement was minor and "does not invalidate" the research....

With the charge against Popovic pulverized, ORI withdrew 
its case against Gallo presumably foreseeing it would meet with equal contempt and whining that the Appeals Board had set a higher standard. In fact, it was O.R.I. that had proposed a lower one, claiming it only needed to prove a statement false to establish scientific misconduct, regardless of intent. Sorry, said the Appeals Board, the regulation defining scientific misconduct doesn't say "false." It says "falsification," which requires proving an intent to deceive....

In Gallo's rush for the AIDS virus, he bruised many competitors. His critics mistook his sharp elbows for itchy fingers. They were far too slow to correct their misjudgment of the one scientific hero who has yet emerged in the fight against AIDS.

This piece by Wade was illustrated by a drawing representing Gallo's face as a martyred saint, halo included.

Readers of the present book have plenty of documentation from which they can verify that Wade's piece misrepresents the record of the Gallo-Popovic case. I don't want to be repetitive, but I shall summarize briefly a few salient points about that piece.

- Differences between the Popovic and Gallo cases. Wade's use of the Appeals Board phrase that there wasn't even "a residue of palpable wrongdoing" in connection with Gallo is a misrepresentation. Indeed, this phrase was addressed to the Popovic case, not the Gallo case, which is completely different in several important respects. For example, Popovic in a draft manuscript of the Popovic et al. paper had written two sentences giving credit to the French: "LAV [the French virus] as a reference virus ... had been used in the first series of experiments" and "LAV is described here as HTLV-III." Gallo struck out both statements and wrote in the margin, "I just don't believe it. You are absolutely incredible" and "Mika you are crazy," as I have explained in detail in my reply to Gallo. Furthermore Popovic gave the drafts of the paper with Gallo's marginal notations to his sister in Czechoslovakia, because he believed that, "... sometime in the future, I might need them as evidence to prove that I gave fair credit ..." to the Pasteur scientists. (15 May 1991 Popovic to Hadley memorandum, p. 7.)

The ORI deserves criticisms for having brought up the Popovic case instead of focusing entirely on the Gallo case, in light of the very different roles played by these two scientists. Fred Richards himself made this point explicit. For instance, Science and Government Report (15 May 1994) states: "Richards also faulted the OSI Report for focusing blame on subordinate Popovic, rather than laboratory chief Gallo, who, Richards said, had the duty to 
'monitor the performance of all personnel in the laboratory and to pay particular attention to the accuracy of major publications which bear his name as author."

- A "lower standard of proof"? The same issue of Science and Government Report also stated that "Richards, who testified for the government in the Popovic misconduct hearing, describes the Appeals Board decision as 'atrocious,' a view shared by other researchers encountered by SGR. The Departmental Appeals Board is mainly occupied with cases concerning Social Security payments and eligibility, and has virtually no experience or competence in scientific issues...."

- Concerning Gallo's putative "achievement." Wade asserted that "Gallo's achievement was greater than has been generally understood, since it far exceeded the mere co-discovery of the AIDS virus with which he is credited." In fact, on 11 July 1994, NIH and the Institut Pasteur revised the agreement concerning royalties for the HIV-antibody blood test, giving to the Institut Pasteur a greater share of the royalties. Harold Varmus, Director of NIH, stated at the time: "The acknowledgment of the role of the Institut Pasteur in isolating the AIDS-causing virus was very slow to occur." See XVI, §3.

Readers can also compare Gallo's "achievement" with what is described in the ORI "Offer of Proof," which states (p. 47): "The evidence will show that Dr. Gallo took a cell line identified by another scientist-'HUT-78'-and used it to successfully, continuously grow the AIDS virus, first LAV, then LAV as 'MOV,' then the 'pool' isolate, 'HTLV-IIIb.' Dr. Gallo renamed the cell line 'HT,' and when he published his findings, he misrepresented and obscured the origins of the cell line so that its true identity could not be discerned. Thereafter, for a prolonged period, Dr. Gallo failed to diligently seek out the truth about the origins of 'HT.' Even faced with important evidence from multiple sources that HT was HUT78 , Gallo failed to acknowledge this fact to the scientific community."

- The patent application. A memorandum of the HHS Office of the Inspector General (10 June 1994) stated that the patent examiner was unaware of the extent of the French work at the time she examined Gallo's patent application, and she said that Gallo should have disclosed it. Had she known more about the situation with LAV, "she would have suspended prosecution of the Gallo application and declared an interference between the two applicants," that is, the Institut Pasteur and Gallo. For further direct quotes from the IG memorandum, see XV.

- Concerning the reporting by the Chicago Tribune. Comparing 
the statements of Crewdson in the Chicago Tribune and the official documents stemming from ORI, the HHS Inspector General, and Fred Richards, I have not found any false statement or misrepresentation by John Crewdson in the Chicago Tribune.

"Sharp elbows" or "itchy fingers"? Nicholas Wade asserts that Gallo's critics "mistook his sharp elbows for itchy fingers." At some point the scientific community, let alone readers of the New York Times, have the responsibility to decide on the available evidence. Fred Richards is quoted in Science and Government Report ("Advisor in the Gallo Case Calls for Reopening Probe," 15 May 1994): "The major purpose of this whole investigation was to find out whether they stole the virus. The answer is, they stole the virus. But we didn't know that at the time these [investigative] reports came out." See XVI, §2.

Science and Government Report. In the article "Saint or Scoundrel? The Gallo Controversy Goes On" (Science and Government Report, 1 February 1994), Dan Greenberg reported various reactions to ORI's withdrawal of charges in light of the Appeals Board rulings. The article by Nicholas Wade was mentioned and quoted, as well as a "contrary view" contained in a letter to ORI dated 30 December 1993, by Donald P. Francis, who headed the AIDS Laboratory at the Centers for Disease Control in the early days of AIDS research. Don Francis had been scheduled by ORI to testify against Gallo (cf. the "Offer of Proof," excerpt from page 97 in Appendix 3). Dan Greenberg quoted from the letter of Don Francis as follows:

From the letter of Don Francis to ORI, dated 30 December 1993. "... the case is a sore in the history of science which will not disappear. The fact that NIH may not want to proceed is an internal NIH issue.... But I fear the sore will continue to fester and will not go away.... The facts of the Gallo case are clear. Unbiased scientists in the field know what happened. I, because of my position as head of the CDC's AIDS Laboratory, saw it up close. In my opinion, Dr. Gallo's behavior was disgraceful, an insult to the integrity of all scientists. Dr. Gallo purposely tried to rob the credit for the discovery of HIV-1 from the Institut Pasteur. It was not passive or an oversight.... The stories of Dr. Gallo's unprofessional behavior go on and on. It is indeed sad. He has contributed and could contribute to science. But when his ethics are so blatantly compromised, how can we believe any of his reports? If NIH refuses to confront these issues, how can we expect junior scientists not to emulate the Bob Gallo's of the world?" 


\section{4. "The Aftermath of the Gallo Case"}

"The Aftermath of the Gallo Case" was the headline of a 7 January 1994 Science article by Christopher Anderson, already mentioned in \$2. I view this article as important in the way it illustrates problems in journalism (not just scientific journalism), and how the article pushed one point of view at the expense of others, thus leading readers in one direction rather than others. Considering the importance that Science has in the scientific community, I shall devote a separate section to a detailed analysis of this article.

I have severe criticisms of this article on several counts. I shall deal only with a few.

1. The title. My first criticism concerns the title, which was inappropriate, because the Gallo case was by no means over. For instance, the investigation by the HHS Inspector General, and Dingell's investigation, were still going on.

Independently of the fact that the Gallo case was not over, the title set the article specifically in the context of the Gallo case. Furthermore, the entire article emphasized the legalistic context at the expense of other contexts for ORI's performance. The subtitle was: "An appeals board trounced the federal misconduct office in two recent cases and said it had misinterpreted its own definition of misconduct; in future, the office will be more selective in the cases it takes on." The article gave weight to so-called "legal standards" without mention of scientific standards, as in the sentence: "Most experts [sic] agree that ... in essence, [ORI] has for years been misconstruing its own rules." In light of certain historical facts which I shall recall, I object to an article which sets "the aftermath of the Gallo case" exclusively in such a legalistic context, and I ask the scientific community to evaluate Science's responsibility in having pushed the legalistic point of view in such an exclusive way.

2. "Misconduct experts" [sic]. In "The Aftermath of the Gallo Case," Science made repeated mention of "experts." Near the beginning of the article, we find (p. 20): "If I were just an observer, I'd think the scientific misconduct process is in great disarray; says Patricia Woolf, a misconduct expert [sic] at Princeton University, who has been an advisor to ORI. In an effort to reduce the confusion, Science asked scientific misconduct experts [sic]- 
scientists, university administrators, and lawyers-to assess the impact of the four cases and their likely effects on future cases." The point of view of the article is then clearly stated: "Their almost universal conclusion: To make a charge of scientific misconduct stick, ORI will have to meet higher standards of proof than it has applied in the past.... Most experts [sic] also agree that ORI should have been applying the standard all along, that in essence it has for years been misconstruing its own rules." In the next column, we read (p. 20): "The bottom line, according to the experts [sic] Science consulted, is the emergence of a distinct, two-tiered system for handling misconduct." I have already mentioned the reference (p. 22) to "Rebecca Dresser, a misconduct expert [sic] at the Case Western Reserve University Law School."

This repeated use of the word "expert" provided a backdrop of authority for the Science article. How legitimate was this backdrop?

Science's selection of certain so-called "experts" directed certain conclusions in certain directions. Another selection of scientists would have provided other directions.

(a) Goodstein. Among the so-called expert "scientists, university administrators, and lawyers" contacted by Science were Paul Friedman, Dean for Academic Affairs at the University of California, San Diego, and a member of ORI's recently disbanded Advisory Board; and David Goodstein, Vice Provost at Caltech. Anderson included quotes from both of them as follows:

"If [ORI] would only have had the sense to go after the clear cases and leave the crap alone, they wouldn't have had these problems." [Friedman] says. Adds Caltech Vice Provost David Goldstein [sic], "The panel did exactly what should be done by holding a high standard. High legal standards chill investigative zealotry."

I had a high opinion of Goodstein, based on some previous acquaintances with some things he was doing, so I was surprised by that quote. I wrote him a letter dated 1 February 1994 to check with him directly whether he was correctly quoted, and whether his opinion was based on correct information. He replied on 9 February that the Science reporter did "misquote" him, and explained his position more accurately. ${ }^{6}$ In particular, Goodstein

6 I circulated Goodstein's reply of 9 February to a number of people, including Science news editor Ellis Rubinstein, to whom I wrote (24 Febru- 
ary 1994): "Under the circumstances, I think it is necessary that a correction be made in Science. Otherwise the record would stand concerning a specific way that Goodstein criticized the HHS investigations, and that record is incorrect."

Goodstein subsequently wrote me (25 April 1994): "My letter to you, dated February 9th, was a personal one with no cc list. Your act of sending my letter to Science, without my permission and without consultation, and demanding on my behalf a retraction from them was, in my view, a violation of trust sufficiently grave that I am no longer willing to correspond with you."

Thus Goodstein raised serious points, typical in filemaking, and deserving an answer. I replied on 4 May 1994 addressing myself to these points.

Personal letters. First, Goodstein's letters to me of 9 February and 25 April were on official Vice Provost stationery. I do not regard use of Vice Provost stationery, answering publicly raised questions about the legitimacy of an official quote in Science, as "personal." Indeed, on 9 February, Goodstein was answering my letter of 1 February, which itself was in the context of an open "file," with cc lists to all my letters, including my letter to him.

Considering the fact that Science used his name and position to reinforce a tendentious point of view in their article, going to their subscription list of 150,000 and readership of 1 million, I did not accept to hold a discussion about this public use of the Caltech Vice Provost in the context of what he calls a "personal" letter. I hold officials, especially those quoted as "misconduct experts," publicly responsible for the views they express in an official capacity.

Request for a correction. Second, I answered that I had not written on his behalf but on my behalf, as quoted above, that is "I [sic] think it is necessary that a correction be made in Science." By withholding from my cc list the information that Goodstein gave a "rambling explanation," his insistence that he knew nothing about the Gallo case, and the more accurate description of his position that he wrote me. I would become an accessory after the fact to the misrepresentations in Science.

Journalistic responsibility. Furthermore, Science held an interview with Goodstein. They selected quotes from a "rambling explanation," and printed the quotes in an issue of Science with a subscription list of 150,000 and a readership of 1 million. Science did not ask Goodstein's permission to print their selection. At best they had notes from the reporter, not even over Goodstein's signature. Colin Norman wrote to Goodstein that Science stood by these notes (letter dated 7 March 1994).

On the other hand, my letter to Goodstein of 1 February constituted a much more careful interview, in which I put four questions to Goodstein concerning the way he was quoted in Science, and the issues raised by "The Aftermath of the Gallo Case." My letter to him was in the context of a public challenge to this article. I did my homework, by not accepting at face value what Science attributed to Goodstein, as Vice Provost. I checked with the original source. He had my questions in writing. I did not rely on notes for his reply. I relied on his full letter over his signature on official Vice Provost stationery. I claim that my journalism was responsible in a way that Science's journalism was not, and I don't under- 
wrote me about the phone interview with Christopher Anderson: "When he asked for my reaction to what had happened, I told him I had not been following the Gallo case, knew nothing about it, and had nothing to say about it.... Before, during and after this discussion [with Science reporter Christopher Anderson], I insisted I knew nothing about the Gallo case." Goodstein also wrote me: "Surely Anderson was trying to compress my rambling explanation into one sentence. You can judge for yourself whether he did it accurately. He certainly had no right to put it in quotation marks, or imply that it was meant to refer to the Gallo case." Anderson did not represent Goodstein accurately. To pass off an uninformed "rambling explanation" in the sliver of a quote reproduced above is not my idea of a proper representation of Goodstein's position, and constitutes a distortion of Goodstein's uninformed rambling explanation. Furthermore, adding a sliver of a quote next to Friedman's "crap" gave Goodstein's uninformed rambling explanation a flavor which was Science's choice. Was it Goodstein's choice?

Science subsequently printed an item labeled "corrections and clarifications." 7 In light of Goodstein's letter to me, I conclude

stand Goodstein's characterizing my journalism as a "violation of trust."

Corresponding with me. Goodstein wrote me that he was "no longer willing to correspond" with me, and that I "should not expect to hear" from him again. Of course, it is his prerogative to hold interviews with Science but not with me, and he has no responsibility to communicate with me again. However, he has the public responsibility not only vis-àvis readers of Science but on the record, for the quotes Science attributed to him, modulo the "corrections and clarifications" published subsequently by Science, see below.

It remains for readers to evaluate the way Science, Goodstein, and I exercised our respective responsibilities, especially our journalistic responsibilities.

7 [I reproduce in full one of the two items which appeared in Science, 22 April 1994, following the letters to the editor, page 492, under the heading Corrections and Clarifications.]

In Christopher Anderson's News \& Comments article "The aftermath of the Gallo case" (7 Jan., p. 20) the name of David Goodstein, Caltech vice provost, was spelled incorrectly. Brackets were also inadvertently omitted around three words in his statement about the impact on scientific misconduct investigations or recent rulings by a federal appeals board. The quotation should have read, "The panel did exactly what should be done by holding a high standard. [High legal standards] chill investigative zealotry." Goodstein was commenting generally on misconduct investigations, not on the Gallo case. 
that this item perpetuated misrepresentations. For instance, Goodstein was quoted as one of several "misconduct experts" [sic]. Informing readers that Goodstein knew nothing about the Gallo case (let alone quoting him to this effect) might have made readers question whether Goodstein rated as an "expert" or not, especially insofar as he referred to the "panel" (Appeals Board). However, Science still withheld from its readers the fact, "insisted" upon by Goodstein, that he knew nothing about the Gallo case, and thus still used Goodstein's quote (whether or not questioned per se) illegitimately. Therefore, I regard the way Science handled Goodstein's uninformed rambling remarks, by compressing them into a sharp "expert" statement without any indication that these remarks were rambling or uninformed, to be manipulative, of Goodstein, of the reader, and of the facts.

Despite the added comment that "Goodstein was commenting generally on misconduct investigations, not on the Gallo case," the Goodstein quote stood as saying: "The panel did exactly what should be done by holding a high standard. [High legal standards] chill investigative zealotry." At this point, I shall not reproduce the longer explanations which Goodstein wrote me on 9 February. Absent any further statement from Goodstein, he is responsible on the record in Science for comments supporting "the panel," i.e., the HHS Appeals Board, at the expense of ORI. The combination of quotes from Friedman and Goodstein reinforced the overall point of view of the Science article, which was to support a legalistic point of view, and to discredit the efforts (however clumsy and partly incompetent) of ORI, and the Richards Panel, to get at the truth. ${ }^{8}$

(b) Selectivity of the "experts." The "expert" scientists contacted by Science did not include scientists who, in various ways, had reservations about the Appeals Board decision. I list some such scientists.

- Fred Richards explicitly expressed a point of view shortly after the Appeals Board ruling on Popovic: "For the kind of things we're dealing with in Gallo, the lawyers have no business being here at

8 I find it appropriate here to recall the statement on Scientific Conduct issued by the Councils of the National Academy and Institute of Medicine, and the Executive Committee of the National Academy of Engineering, 2 February 1994, containing the sentence: "As members of the professional research community, we should strive to develop and uphold standards that are broader than those addressed by the government regulatory and legal framework for dealing with misconduct in science." [Underlining in the original.] 
all. They're not going to contribute anything except exacerbation. The scientific community is perfectly capable of handling these things itself. We have done so for years." ("U.S. may not fight appeal by Gallo," Chicago Tribune, 10 November 1993, p. 1.)

- Priscilla Schaffer, a professor at the Harvard Medical School, was quoted in the Chicago Tribune immediately following Fred Richards: "Many of the conclusions that this board of nonscientists reached were really unscientific." According to the Chicago Tribune, Priscilla Schaffer "testified for the government against Popovic and was scheduled to testify against Gallo."

- Donald P. Francis was quoted as mentioned above in Science and Government Report (1 February 1994).

- John Edsall (I know also of three others) wrote to Dingell: "I believe that the standards of ethical conduct for scientists are, and should be, more demanding than the purely legal ones." Edsall concluded his letter to Dingell by observing that "the attempt to clear Dr. Gallo of all legal charges against him is on the verge of complete success. If you have strong evidence that could lead to a different conclusion, would not this be the time to make it public, in the interest of truth and honesty, and perhaps also of appropriate legal action?" (Quoted in Science and Government Report, 15 March 1994, "With Gallo Exoneration Looming, Dingell Asked to Act," p. 3.)

No scientist's point of view remotely related to any of these was mentioned in the Science article "The Aftermath of the Gallo Case" (or the subsequent ScienceScope article, see below). The three pages of "The Aftermath of the Gallo Case" in Science were devoted to placing the Gallo case in the context of "American legal standards," as a Science editor Colin Norman wrote to Goodstein in a letter dated 7 March 1994. The legalistic context deemed worthy of three pages by Science completely left out a point of view of some scientists that a legalistic approach to cases such as those of Gallo (and Baltimore previously) is undesirable, or whatever expressions various scientists would use. Each one has their own way of formulating their point of view. In particular, Paul Doty, who went public in the context of the Baltimore case, warned that science "risks sliding down toward the standards of some other professions where the validity of action is decided by whether one can get away with it. For science to drift toward such a course would be fatal..." (Nature, 18 July 1991, p. 183). The Science article "The Aftermath of the Gallo Case" provides documentation of such a slide, not just the "risk" of such a slide. Paul Doty was not one of the "misconduct experts" mentioned by Science. The bottom line is that the 3-pages long Science article "The 
Aftermath of the Gallo Case" pushed the point of view of legal standards at the expense of other standards, e.g., scientific standards.

Also not mentioned were Suzanne Hadley, nor anyone on Dingell's staff, nor anyone from the HHS Inspector General's office, let alone mentioned as "experts." However:

- Suzanne Hadley is an extraordinarily well-informed person, because she originally directed the Gallo investigation until she was "reined in"-i.e., forced out-by Bernadine Healy. Then until 15 April 1994, she was on detail from HHS to advise the Dingell Subcommittee on Oversight and Investigation about the facts of the case and about documentation which could be available in the files of NIH. By placing "The Aftermath of the Gallo Case" in the context of American legal standards," at the expense of a context whereby Science would recall the history of the Gallo case, including the "reining in" of Suzanne Hadley by NIH Director Healy (Science, 26 July 1992, p. 372) represented a definite choice of one point of view over another.

- Dingell's opening statement at the hearings of 21 July 1993 brought up the possibility that HHS officials "suppressed evidence" for the patent application of the HIV blood test, and that his investigation encountered "repeated instances of obfuscation and obstructionism on the part of past and current Government officials.... Documents have been destroyed. Documents have been withheld for protracted periods. In several instances, key documents known to exist have never been produced from the official files...."

- The HHS Inspector General was still to be heard from, and we shall deal with the Inspector General later.

I object to Science's selectivity of "experts," which resulted in leaving out of Science's article important material and informed points of view which could have been provided by scientists such as those mentioned above, as well as by Suzanne Hadley, Dingell, or the HHS Inspector General.

3. No historical context of the Richards Panel. Nowhere in "The Aftermath of the Gallo Case" (and a subsequent ScienceScope piece) did Science recall the origins of the Richards Panel, namely the solicitation in 1990 by HHS and NIH to the NAS "to nominate a slate of qualified observers to verify the independence and thoroughness of the NIH's own investigation," as reported by Barbara Culliton in Science, 23 February 1990. Culliton wrote further, "We decided to go the 'extra mile' for the NIH's sake and for Dr. Gallo's," Raub told Science "...Press and Thier 
[President of the NAS Institute of Medicine] have agreed to propose such a panel with the stipulation that Mason confine his selection to that list and agree not to add anyone recommended by the government, which can be said to have a stake in the outcome because it is a signatory to the U.S.-French agreement...." Thus the commitment of HHS-NIH to the NAS was not legalistic but scientific, directed toward "independence and thoroughness," not toward a dependency on "American legal standards."

Did Science contact members of the Richards panel for the article? If Science did not, it was a serious omission. If Science did contact members of the Richards Panel, and they refused to issue a statement, this fact deserved to be reported in light of previous commitments by the Richards Panel to "speak out loud and clear," as reported by Science itself when Barbara Culliton wrote: "Sources say committee members have promised not to discuss their deliberations until they are complete. At that point, they expect to "speak out loud and clear'." ("Inside the Gallo probe-The Committees," Science 22 June 1990).

I also recall here that Gallo himself was quoted in the Culliton Science 23 February 1990 article, as supporting "the decision to name outside advisers." "I welcome this," he told Science. "These allegations have been going on too long. I have done nothing wrong and I have no apprehension or anxiety about the review. And, I'm confident that the only chance I have is the help of independent colleagues." These colleagues came to the conclusion that there was "a pattern of behavior on Dr. Gallo's part that repeatedly misrepresents, suppresses, and distorts data and their interpretation in such a way as to enhance Dr. Gallo's claim to priority and primacy.... Given the quality of the information derived from propagation of the French virus, we believe that this constitutes intellectual recklessness of a high degree-in essence, intellectual appropriation of the French viral isolate."

Thus Gallo's "only chance" ultimately was not "the help of independent colleagues" but lawyers and what some people call "legal standards."

However, in its "Aftermath of the Gallo Case" and the subsequent ScienceScope article, Science did not place current events and the rebuff of ORI (and subsequently of the HHS Inspector General) by the legal system in the historical context recalled above. Science did not deal with the significance of the complete breakdown of the commitments made in 1990 by NIH-HHS, as well as the commitment by the Richards Panel "to speak out loud and clear." Such a breakdown of commitments is certainly part of the Gallo case, and will be part of its aftermath, but Science chose 
to report matters in an entirely different context, favorable to the legal system and insulting to ORI ("leave the crap alone," "[High legal standards] chill investigative zealotry").

Therefore I call Science's journalism tendentious, and I object.

\section{Limited hangout in the "Corrections and Clarifications."}

From January to April 1994, I communicated my objections described in this section concerning "The Aftermath of the Gallo Case" to Science news editor Ellis Rubinstein. In light of these objections, I regard the "corrections and clarifications" (reproduced in footnote 6) as a limited hangout. For example, Ellis Rubinstein had written to me (letter dated 19 January 1994): "Nevertheless I think you have a point about our headline over our 7 January story: it probably implies more than it should. For that, you should not blame Chris [Anderson] but his editors. While some institutions choose never to concede error of any sort, the Science staff attempts to hold itself to a higher standard." No mention of the defective title was made in the "correction and clarification." Even more importantly, the correction or clarification did not address the deeper objections transcending specific misrepresentations of Goodstein, namely that the whole context of "misconduct experts" was illegitimate and was used to push certain points of view at the expense of others.

Ellis Rubinstein also wrote me on 6 April 1994: "I have admitted failings on our part-not of course sufficiently to satisfy youand upon occasion have left open the possibility that we erred more than we realize." There is no indication of any further errors in the "corrections and clarifications" printed in the Science issue of 22 April 1994, and Rubinstein did not answer my request for a list of items about which Science "erred more than" he and other editors realize. As far as readers are concerned, the only corrections or clarifications are those made in Science, 22 April 1994, and therefore the above sentence by Ellis Rubinstein is mere verbiage.

\section{Previous misreporting by Science; no mention of the ORI} Offer of Proof. "Corrections and Clarifications" were needed not only about misquoting Goodstein, but also about the most recent events in the Gallo case. I shall just give one further example here, also having to do with previous misreporting of so-called "facts" by Science concerning Gallo. Such misreporting is indeed part of the Gallo case and its "aftermath," if and when an aftermath ever occurs. For example, in 1985, Science reported Gallo's response to the allegation that the retrovirus given to Gallo's 
group by the Institut Pasteur was used in contravention of the terms of the agreement with the Institut Pasteur. Colin Norman wrote (Science, 8 November 1985): "Gallo indignantly disputes the allegation on several counts, including the fact [sic] that the viruses are not identical and that the amount of virus Montagnier sent would not have been sufficient to infect a cell line (see box on page 643)." On the other hand, sequencing analyses subsequently showed that the French virus LAV was the same as other viruses used by Gallo for the blood test, and in the Offer of Proof by ORI (see Appendix 3), we read:

\section{From the ORI Offer of Proof.}

p. 77. The evidence will clearly demonstrate that Dr. Popovic had transmitted LAV into a permanent cell line. Dr. Popovic admitted this fact to OSI when he also indicated that LAV grew very well. Exhibit H-319.... Dr. Gallo was informed that LAV was grown in a permanent cell line.

p. 79. The evidence will clearly reveal that the LTCB had grown the LAV virus in a permanent cell line prior to January 1984.64 Additionally, Dr. Gallo clearly knew of this growth prior to publication of the Science papers in May 1984. Exhibit H-66. It is equally clear that the LTCB was refusing to share that information See e.g. Exhibit H-60.... Prior to publication of the at-issue Science paper, Dr. Gallo acknowledged that he was aware the Pasteur scientists had LAV in a cell line. See Gallo press conference of April 23, 1984 , at $31 \ldots$.

What is the responsibility of a magazine, let alone the \# 1 scientific magazine, to print a correction after reporting as "fact" something which turns out to be false? I wrote to Ellis Rubinstein on 30 March 1994 that it would have been appropriate for Science to follow up the above-mentioned article by Colin Norman, by publishing a correction to the past illegitimate use of the word "fact." I also asked him, in case such a correction had already been published, to bring the correction to my attention. I had no answer from Ellis Rubinstein to this request.

Thus in addition to the selectivity already described, "The Aftermath of the Gallo Case" left out of consideration the substance of the Gallo case, as well as the documentation accumulated in the ORI Offer of Proof. In that article, Science emphasized legalistic aspects in such a way as to discredit ORI, but Science did not even mention the ORI Offer of Proof with its meticulous layout of evidence. There is no indication that any of Science's so-called 
"misconduct experts" brought it up either. And Science did not take this opportunity to issue "corrections and clarifications" for passing off a falsehood as a "fact."

We touch here on fundamental journalistic responsibilities. Unfortunately, it takes much more space to document the tendentious character of Science's reporting than it took for this reporting to occur in the first place.

\section{The Richards Panel vis-à-vis the Appeals Board}

The Richards Panel was systematically rejected by the Appeals Board. In the first place, of course, no member of this panel was on the Appeals Board.

Some scientists testified at the Popovic hearings. According to Science ("Popovic Is Cleared on All Charges; Gallo Case in Doubt," 12 November 1993, p. 982), "the board also rejected much of the testimony from ORI's expert witnesses, including Yale's biochemist Frederic Richards, who headed a committee assembled in 1990 by the National Academy of Sciences to advise federal investigators." In Appendix 2, I shall quote an entire paragraph from ORI's evaluation of Fred Richards testimony. The Appeals Board gave "little weight" to his testimony because "his opinions were developed based on selected information given him by ORI," and "he did not have a background in cell biology, virology, or retrovirology." Concerning the "not done" annotation in the Popovic et al. paper, the Appeals Board found "that he [Richards] could not reliably comment on whether 'not done' had a particular meaning in these disciplines." The above-mentioned Science article quoted Fred Richards as countering: "Not done means not done and anybody who thinks otherwise is crazy."

The rejection of Richards' testimony was in line with two rulings of the Appeals Board, reproduced in Appendix 1. One of them required that "for testimonial evidence, ORI must offer proof that its witnesses are competent to testify as to the standards of conduct in the scientific community of which Respondent was a part in 1983-1984..."; the other is that, "if ORI relies on two or more ... findings as cumulatively establishing that Dr. Gallo engaged in misconduct while not alleging that each alleged instance of conduct was alone scientific misconduct, ORI must also offer proof that there was in the scientific community in 1983 and 1984 a standard that permitted unrelated instances of conduct which did not amount to scientific misconduct to cumulatively constitute 
scientific misconduct...." Such a ruling went directly against the criticism of the OSI Report made by the Richards Panel, that the OSI Report failed "to integrate the findings into a larger context, namely a pattern of behavior on Dr. Gallo's part that repeatedly misrepresents, suppresses and distorts data and their interpretation in such a way as to enhance Dr. Gallo's claim to priority and primacy."

Fred Richards subsequently stated that he was "absolutely shocked by the attitude of the Board" (Chicago Tribune, 5 November 1993, p. 18).

In the news articles which I have mentioned above, I did not see any statements from members of the Richards Panel commenting on the dropping of charges against Gallo. I find it appalling that the scientific establishment could remain silent after the handling of the Richards Panel (and other scientists) by NIH and HHS, ranging over:

- the original pretenses under which it was nominated;

- the resistance to its recommendation for an investigation;

- the abuse and manipulation of this panel by NIH Director Bernadine Healy;

- the withholding of information from this panel by NIH; and

- the ultimate explicit rejection of this panel by HHS.

The entire history of the NAS-nominated Richards Panel represents failures of responsibility and evasions of responsibility across the board:

- by NIH and HHS for having solicited the NAS to nominate a panel of scientists to give credibility to their investigations, and then for having systematically put down, manipulated, and rejected this panel;

- by the panel itself for having accepted to work under the conditions imposed progressively by NIH and HHS; and

- by the scientific leadership of the country, especially the NAS, for having washed its hands of the whole matter.

Given the history of the Richards Panel, how can scientists accept in good faith invitations to consult for NIH and HHS? How can the public expect the scientific community to police itself? How can scientists, or the public, trust NIH and HHS investigations, after the chaos, incompetence, contradictions, breach of commitments, evasions, suppression of information, and manipulations by the top officials of NIH and HHS which have been 
documented? The only valid answer I see today is that they can't.

I also ask whether the scientific community is willing to adapt its standards of behavior to the point where if something is legal, then it's OK? To what extent does the scientific community accept a defense of a scientist's actions by appealing to legal criteria, especially when some of us insist that science and scientists must be judged by our own standards and all of us want science to be self-policing?

\section{APPENDIX 1 \\ Excerpts from the conditions set forth by the Appeals Board \\ Certified Mail sent to Gallo's lawyer, Joseph Onek, and to the Office of the General Counsel, ORI 6 July 1993}

Respondent, Dr. Gallo, sought a ruling to dismiss these proceedings.... If ORI's offer of proof does not meet the requirements set out below, we will grant Respondent's motion to dismiss in whole or in part based on a determination that no reasonable basis exists for proceedings to adjudicate part or all of ORI's proposed findings....

7. The key issue here, however, is whether Respondent reasonably could have anticipated at the time of this alleged conduct that such conduct, if proved, would constitute "scientific misconduct." If ORI cannot prove that Respondent could have reasonably anticipated that his conduct was "scientific misconduct," then its case is legally insufficient, for the following reasons:

- Even assuming Respondent engaged in the alleged conduct, this fact alone would not impugn Respondent's research integrity.

- If his integrity is not impugned by the conduct, no administrative action to protect the federal government interest is needed or appropriate.

- Applying the label to Respondent in such circumstances would be fundamentally unfair.

...

12. In the absence of any specific definition of scientific misconduct in a statute or regulation in effect at the time of the conduct, ORI must prove that the nature of Respondent's violation of applicable standards of conduct was such that any reasonable researcher in his position would have considered it scientific misconduct at the time. 
14. We conclude that ORI misread the definition [of "misconduct in science"] in Section 50.102, which we have concluded sets a limit on the scope of this proceeding, for the following reasons:

- To the extent ORI implies in its arguments that any false statement may be a basis for a finding of scientific misconduct, ORI's arguments are inconsistent with the definition at section 50.102.

- The definition (1) uses the word "falsification" (which implies more that simple falsity); (2) refers to "other practices that seriously deviate from those that are commonly accepted within the scientific community for proposing, conducting, or reporting scientific research;" and (3) specifically excludes "honest error or honest differences in interpretations or judgments of data."

- This definition cannot reasonably be read as encompassing falsification or any other conduct which does not seriously deviate from commonly accepted practices within the scientific community or which results from honest error or honest differences in interpretation of judgments of data.

- Since ORI has the burden of proving scientific misconduct by a preponderance of the evidence, ORI must therefore, prove here that the alleged misconduct did not result from honest error or honest differences in interpretations or judgments.

15. ... If we do not receive such an offer of proof with respect to each allegation, we would dismiss this proceeding with regard to that allegation. To do otherwise would result in this Department committing its resources for a proceeding which could not lead to a legally supportable result in ORI's favor....

\section{WHAT IS REGUIRED FOR ORI'S OFFER OF PROOF}

For each of the four findings of censurable conduct [referred to as A1 through A4 in the order stated on pages 52 and 54 of the ORI Report], and for the finding for Allegation 8, ORI must make a separate offer of proof....

For each finding ORI must address each element listed in bold below.

... For Al-ORI must offer proof that the changes proposed by Dr. Gallo were gratuitous and self-serving....

...For Allegation 8-ORI must offer proof that the statement in question falsely reported the status of LAV research.

...For A3-ORI must offer proof that there was a standard of conduct in 1983 and 1984 for laboratory chiefs at NIH requiring 
them to supervise recordkeeping by senior scientists and their technicians....

...For A4-ORI must offer proof that there was a standard of conduct in 1983 and 1984 which required Dr. Gallo, under the particular circumstances, to take actions which he did not take to determine the source of $\mathrm{H9}$ and that there was a standard of conduct at that time concerning access by other researchers to a cell line such as H9.

- If intent is necessary to render the deviation from the standard serious or otherwise to render the conduct scientific misconduct, Respondent had that intent.

For testimonial evidence, ORI must offer proof that its witnesses are competent to testify as to the standards of conduct in the scientific community of which Respondent was a part in 1983-1984 applying to someone in Respondent's job position at NIH at the time. For documentary evidence, ORI must produce that document or cite to it by proposed exhibit number.

Moreover, for each finding Al through A4, ORI must state whether that finding alone is a finding of scientific misconduct. IF ORI relies on two or more of the Al through A4 findings as cumulatively establishing that Dr. Gallo engaged in misconduct while not alleging that each alleged instance of conduct was alone scientific misconduct, ORI must also offer proof that there was in the scientific community in 1983 and 1984 a standard that permitted unrelated instances of conduct which did not amount to scientific misconduct to cumulatively constitute scientific misconduct which impugned the integrity of a researcher....

\title{
CONCLUSION
}

ORI's offer of proof must be submitted within 14 days of the receipt of this letter. Although we gave ORI an opportunity to clarify its offer of proof in Board Docket No. A-93-100, we do not intend to provide such an opportunity here.

In accordance with this ruling, these proceedings will be dismissed with regard to any allegation for which ORI does not present the offer of proof described above.

\author{
s/Judith A. Ballard \\ s/Norval D. (John) Settle \\ s/Cecilia Sparks Ford \\ President Panel Member \\ Research Integrity \\ Adjudication Panel
}




\section{APPENDIX 2 \\ Excerpts from the "DECISION" of the Appeals Board SUBJECT: Mikulas Popovic, M.D. \\ 3 November 1993}

Docket No. A-93-100, Decision No. 1446

... In spite of the narrow focus of this proceeding, this case has compelled us to parse a record reflecting years of investigations, thousands of pages of documents and lawyers' briefs, a hearing which lasted 12 days, and the time, attention and disagreement of dozens of scientists, investigators, and lawyers-all focused essentially on the meaning which we should give a handful of words and notations contained in one heavily-edited paper written by a scientist with limited English skills during a volatile period of scientific discovery a decade ago. The paper in question, it is undisputed, made a major and lasting contribution to establishing that a retrovirus was the etiological agent of AIDS-even assuming the most ambitious reading of error into the parts in question here.

One might anticipate that from all this evidence, after all the sound and fury, there would be at least a residue of palpable wrongdoing. That is not the case. On reviewing this lengthy record and all the evidence and argument related to each of ORI's allegations, and notwithstanding the vigorous efforts of ORI counsel, we find that ORI was simply unable to prove by a preponderance of the evidence that Dr. Popovic is guilty of scientific misconduct-even under standards first promulgated years after the paper was published....

We found the following general flaws in the evidence ORI presented:

- Each of the findings of scientific misconduct was based on reading in particular way language which, in context, was merely ambiguous....

- The opinions given at the hearing by ORI's scientific advisors were based on misunderstandings about what was involved in the research at issue and what Dr. Popovic and others had said. While these advisors were experts with impressive credentials, they were not asked by ORI to conduct a first-hand investigation. Their information was largely derived from the ORI investigators' understandings, which in some in- 
stances ignored or misrepresented evidence in the record. Moreover, none of these advisors had direct experience isolating a novel retrovirus. Since their opinions were based on a number of erroneous assumptions, they were largely irrelevant. Testimony by the one retrovirologist who testified for ORI who could be considered a disinterested expert supported Dr. Popovic's case more than ORI's.

- These advisors drew unreasonable inferences from the nonscientific evidence in the case....

- ORI and its experts also did not have a clear idea of the proper legal and scientific standards to apply to Dr. Popovic's conduct. They faulted him simply for doing things differently from how they would have done things. In evaluating Dr. Popovic's conduct against their own, they also applied their experience in other disciplines in a way that failed to take into account the nature of the experiments reported in the Science paper at issue and the status of AIDS research at the time.

- ORI gave an importance to the matters at issue here which is not justified when the paper is examined as a whole. None of the matters here has any significance to the validity of the major conclusions of the paper....

[Concerning a disputed sentence in the Popovic et al. paper, the Appeals Board commented on the scientific advisors to ORI as follows, p. 22.]

We found the testimony on this sentence by the scientific advisors who had been involved in ORI's investigation (Drs. Richards, Berns, and Schaffer) to be either irrelevant or unpersuasive-in spite of these experts' impressive credentials, for the following reasons:

- Based on their testimony as a whole, as well as their own descriptions of their role in the investigation, we find that these advisors did not form their opinions independently, after consideration of all the relevant evidence...

- None of these experts appeared to have carefully examined the language and context of the disputed sentence, or to have independently tested it against the record....

[Concerning an annotation "ND" concerning an experiment which was claimed to have been done, but actually was "Not Done," a question arose as to what the abbreviation "ND" meant. I quote from a passage on page 43 referring to Fred Richards. The letters Tr below refer to the transcript of testimony.] 
... For its position that "ND, not done" meant "not performed," ORI relied on testimony from five witnesses (Dr. Richards, Dr. Hadley, Dr. Martin, Dr. Watkins and Dr. Gardner). ${ }^{31}$ For the following reasons, we find that ORI's reliance on this testimony is misplaced:

- Dr. Richards was one of a group of scientists who advised NIH during the investigation. The advisors did not themselves undertake to investigate and ascertain whether the statements in issue were false. Tr at 513-15. Dr. Richards testified that the advisors had concluded that the ND data points appeared to be falsified because ND is defined in the footnote to the paper as meaning not done, which is a term of art meaning the experiments were not performed. $\operatorname{Tr}$ at 438,514 . We give little weight to his testimony for two reasons. First, his opinions were developed based on selected information given to him by ORI. See also $\operatorname{Tr}$ at 421, 467-7; 492; 510; 512-13. Second Dr. Richards readily acknowledged that he did not have a background in cell biology, virology, or retrovirology. Tr 15 479-81; 503-04; 56-07. We find, therefore, that he could not reliably comment on whether "not done" had a particular meaning in these disciplines. ${ }^{32}$ We also note that Dr. Richards stated that there are no generally accepted standard symbols to use when you might have ambiguous results or a problem with a particular experiment. $\operatorname{Tr}$ at 520. [I omit footnotes 31 and 32.]

\section{APPENDIX 3}

\section{Excerpts from the "Offer of Proof" from ORI to the HHS Appeals Board \\ In the matter of Robert C. Gallo, M.D. Board Docket No. A-93-91}

[The document is undated, but was sent Federal Express to the Appeals Board and to Gallo's lawyer on 30 August 1993. The document is 99 pages long. This document is available from ORI on request, under the Freedom of Information Act. There is no substitute for the original document, which is meticulous. I have kept the footnote numbers but usually did not reproduce the footnotes themselves. Sometimes they give technical references to testimony, and sometimes they bring up further documentation.]

From pp. 2-6. In its Final Report to the allegations of scientific misconduct against Dr. Robert C. Gallo, the ORI concluded that 
Dr. Gallo committed scientific misconduct with respect to his following statement published in his article in Science: ${ }^{2}$

These findings suggest that HTLV-III and LAV may be different. However, it is possible that this is due to insufficient characterization of LAV because the virus has not been transmitted to a permanently growing cell line for true isolation and therefore has been difficult to grow in quantity.

... In its Final Report, ORI also specifically identified four findings of inappropriate conduct by Dr. Gallo which had provided the essential context for its evaluation of the allegations against Dr. Gallo. ${ }^{3}$ [Footnote reference made here to Crewdson's Chicago Tribune article.] These are summarized below:

Allegation A1. ${ }^{4}$ In April-May 1983, Dr. Gallo inappropriately inserted changes into a paper written by scientists at the Pasteur Institute (the "Barré-Sinoussi paper"). 5 The paper had been forwarded to Dr. Gallo for his assistance in having it accepted for publication by Science. Exhibit H-6. In the process of shepherding the paper, and eventually serving as its peer reviewer, Dr. Gallo both authored an Abstract and made significant substantive modifications which advanced his own hypotheses rather than those of the Pasteur scientists... These representations were not identified as comments by Dr. Gallo but rather added as gratuitous and self-serving changes purportedly representing the views and findings of the French authors.

Allegation A2. Dr. Gallo was Senior Author on the Popovic paper... Thus the paper was replete with at least 22 incorrect statements concerning LTCB research, at least 11 of which were falsifications amounting to serious deviations from accepted standards for conducting and reporting research....

Allegation A3. ORI found that Dr. Gallo's failure or refusal to meet his obligations as laboratory Chief created an atmosphere which interfered with, rather than ensured, the accurate and appropriate conduct and reporting of scientific research. 
Allegation A4. ORI determined that Dr. Gallo failed to determine the source of [the cell line termed] "H9" in a timely manner and placed inappropriate restrictive conditions on access of other scientists to LTCB reagents.

... ORI determined that the preferable course of reporting its findings was to announce its finding of scientific misconduct that Dr. Gallo misrepresented the use and significance of LAV in the Popovic paper in light of the inseparable context of its four other findings. Thus in its Final Report, ORI not only explained its finding of scientific misconduct in Dr. Gallo's false reporting of the use and significance of LAV but also explained the context in which that finding was made and should be evaluated, i.e. the pattern of inappropriate conduct and scientific misconduct articulated in Allegations Al through A4.

... The Board, however, has now ordered ORI to parse its findings to identify which of these areas of censurable conduct, either separately or in the aggregate, constitute scientific misconduct, and for each instance of scientific misconduct, to identify sufficient documentary and testimonial evidence to support a finding of scientific misconduct. In response to this directive, ORI submits this Offer of Proof..

p. 11 Concerning Dr. Gallo's Inappropriate Conduct as Reviewer of the Barré-Sinoussi Paper. Dr. Gallo introduced several improper and self-serving changes in the Barré-Sinoussi paper. ORI will show that Dr. Gallo altered the paper to reflect his own theories about the cause of AIDS. Specifically, ORI will show that Dr. Gallo inappropriately added a sentence: "The virus [LAV] appears to be a member of the human T-cell leukemia virus (HTLV) family." Exhibit H-13 at 868. Similarly, he altered another sentence in the manuscript to read: "We tentatively conclude that this virus, as well as all previous HTLV isolates, belong to a family of T-Lymphotropic retroviruses that are horizontally transmitted in humans..." Id. Dr. Gallo's insertion of these references to "HTLV," coupled with his definition of HTLV as "Human T-Cell Leukemia Virus," rather than "Human T-cell Lymphotropic Virus," deliberately and erroneously linked LAV and HTLV-I. ${ }^{7}$ The Pasteur scientists had made no such conclusion or suggested any such link and, in fact no such link exists. Moreover, Dr. Montagnier has denied seeing any reference to HTLV-I in the draft of the paper he saw prior to publication. Exhibits H-207; H-189, Attachment 1 .... 
p. 12. Through his changes, Dr. Gallo was able to subvert the article to appear to be a confirmation of his personal misplaced theory that the AIDS virus was linked to his own HTLV-I virus...The evidence will further demonstrate that, when Dr. Gallo forwarded the paper to Science with his comments, he clearly downplayed the significance of the changes by disingenuously representing them to the journal editor as "mainly stylistic and grammatical"....

p. 14. Moreover, the evidence demonstrates that the Abstract was not written in concert with the French authors. Rather, Dr. Gallo gratuitously penned the self-serving Abstract to foster his own aims and accomplishments, even over Dr. Montagnier's and Dr. Chermann's protestations. Exhibit H0189; Testimony of Dr. J.C. Chermann...

p. 15. Dr. Gallo was able to accomplish this by, in part, inappropriately taking total control over review of the paper, serving both as mystery co-author and sole peer reviewer in contravention of accepted peer review policies. 10 ORI will show that the fundamental underpinning of the peer review process rests in the objectivity of the reviewer. Unfortunately, Dr. Gallo's actions demonstrate a total absence of objectivity and a conflict of interest, resulting in an undermining of the peer review process.

p. 24. In sum, the testimonial and documentary evidence will demonstrate that Dr. Gallo is responsible as senior author for at least nine separate acts of falsification which were at issue in the Popovic hearing (i.e., two for the "first shown" sentence; four for the "ND" entries in Table 1; one for the " $10 \%$ " entry in Table 1; and two for the "ND" entries in Table 2). Dr. Gallo's failure to correct these false statements is a material breach of his obligations as senior author and Laboratory Chief of the LTCB to ensure the accurate and honest reporting of research. See also allegation A3, infra.

p. 25. The finding for this allegation is not derived wholly from the allegations at issue in the Popovic hearing. Thus even if the Board were to find that Dr. Popovic were not guilty of scientific misconduct with respect to the allegations listed above, Dr. Gallo is nevertheless independently responsible for these falsifications because of his position as senior author of the Science paper and his position as the Laboratory Chief of the LTCB....

In addition to the false statements at issue in the Popovic 
hearing, the Science paper contains 13 other incorrect and misleading statements....

a. The Science paper provided no specification of when and how often fresh cells were added to the HT (H4) cultures depicted in Figure 2a and described in the methods section.... [All 13 "incorrect and misleading statements" are dealt with seriatim, from p. 25 to $p .32$.]

pp. 36-40. Dr. Gallo had an obligation as a Laboratory Chief to ensure that Dr. Popovic and others in the Lab were instructed to be, and were in fact, meticulous in their scientific efforts and recordkeeping methods.... Evidence of Dr. Gallo's failure to supervise and manage the activities of Dr. Popovic and the LTCB adequately will include but not be limited to the following: the LTCB's failure to catalogue appropriately the receipt of the July shipment of LAV from the Pasteur Institute ${ }^{17}$; the LTCB's failure to record culturing of the July shipment of LAV ${ }^{18}$; the LTCB's failure to keep adequate contemporaneous records of Dr. Popovic's alleged reinfections of the Ti7.4 and HUT-78 cell lines with LAV in November 198319; the LTCB's failure to record adequately the results of alleged IFA experiments performed before December 1983 on the LAV sample received by the LTCB from Pasteur in September $1983^{20}$; the Laboratory's failure to record adequately the initiation of the culture later identified by the Lab as MOV ${ }^{21}$; the Laboratory's failure to record adequately any RT, IFGA, or EM data for the "HT"/"pool" purportedly created and used by the LTCB in isolating and growing the AIDS virus ${ }^{22}$; the Laboratory's failure to record adequately the repeated infection of the eight HUT-78 clones purportedly infected with the "pooled" virus ${ }^{23}$; the laboratory's failure to record adequately the infection of the critical samples included in what Dr. Popovic and Dr. Gallo have called a "host range" (February 13, 1984) experiment or to make any record of any experiments other than EMs performed upon the most important of those samples 24 ; the laboratory's failure to record adequately, or even to identify, the two samples labeled " $L$ " that were the first two samples purportedly tested with the rabbit antiserum and found positive for the AIDS virus on February 21 , $1984^{25}$; the LTCB's failure to retain any sample of the pooled culture that was purportedly referenced in the Science paper. ${ }^{26}$

ORI will present witnesses to establish that the very essence of science rests upon adequate recordkeeping. It is incumbent upon scientists to make and keep records sufficient to document each step taken in an experiment in order to allow others to retrace 
those steps, to evaluate the research and to reproduce the experiment. These witnesses will testify that, in the absence of such records, a negative inference is drawn by the scientific community. These witnesses will testify that such recordkeeping is all the more important when a scientist intends to publish his results, especially where those results purport to be ground breaking and the paper is seminal to an area of research. The resources available to the LTCB make these lapses both indefensible and incredible....

p. 41. ORI will present evidence that Dr. Gallo's emphasis on speed, volume, and priority of LTCB publications required imprecision and pushed his laboratory to cut corners and round results. Evidence of this will be produced through LTCB scientists such as Drs. Edward Korwek and Kalyanaraman and from published examples, including the four Science papers. The testimony of Dr. Popovic will be presented to demonstrate that it was Dr. Gallo's rush to publish that contributed to the numerous falsifications and misrepresentations in the Popovic paper. ORI will demonstrate that Dr. Gallo's obsession has been fueled by his knowledge in March 1984 of comparative competitive serology studies completed by the CDC, the LTCB and the Pasteur as well as by what he learned at the Pasteur in April 1984... These events caused him to fear that someone else might be the first to develop and report on the AIDS blood test. 29

Footnote 29: Witnesses such as Dr. Donald Francis, Dr. Luc Montagnier, Dr. Malcolm Martin, Dr. James Curran and Dr. Cabradilla will testify about what Dr. Gallo saw at the Pasteur and the serology studies that caused him to accelerate publication of the papers. ORI will demonstrate that it was his fear of losing primacy that caused him to accelerate publication of the papers. Indeed, the evidence will demonstrate that as early as February 1984 the authors had decided to have the papers ready for publication by late April. However, ORI will show that Dr. Gallo's review of the serology results on March 12, 1984 triggered his decision to accelerate publication, Id.; See also Exhibit H-219.

p. 46. ORI Witnesses. ORI will present the following witnesses to establish the duties of a Lab Chief at NIH and elsewhere and how Dr. Gallo's conduct seriously deviated from the commonly accepted practice in the scientific community and NIH in 19831984: Dr. Richard Adamson; Dr. Edward Brandt; Dr. Walter Dowdle; Dr. Alfred Gilman; Dr. Robert Goldberger; Dr. Suzanne Hadley; Dr. Arthur Levine; Dr. Malcolm A. Martin; Dr. James G. 
Mason; Dr. J. Michael McGinnis; Dr. Howard E. Morgan; Dr. Mary Jane Osborn; Dr. Joseph E. Rall; Dr. William H. Raub; Dr. Frederic Richards; Dr. Joseph Sambrook; Dr. Priscilla Schaffer; Dr. John Stobo; Dr. Robert R. Wagner.

p. 47. 1. Summary of the Offer of Proof. The evidence will show that Dr. Gallo took a cell line identified by another scientist"HUT-78" -and used it to successfully, continuously grow the AIDS virus, first LAV, then LAV as "MOV," then the "pool" isolate, "HTLV-IIIb." Dr. Gallo renamed the cell line "HT," and when he published his findings, he misrepresented and obscured the origins of the cell line so that its true identity could not be discerned. Thereafter, for a prolonged period, Dr. Gallo failed to diligently seek out the truth about the origins of "HT." Even faced with important evidence from multiple sources that HT was HUT78 , Gallo failed to acknowledge this fact to the scientific community. Not until 1989 did Dr. Gallo finally admit that the cell line he used and called "HT" was, in fact, HUT-78. Exhibit H-179 at 254; H0315. Dr. Alan Rabson will testify about the study, published in 1989, that confirmed the identity of H9 and HUT-78....

p. 48. 2. Dr. Gallo's Misappropriation and Misrepresentation of the HUT-78 Cell Line.

(a) Factual background. In the Fall of 1983, Dr. Popovic used several cell lines, including a cell line he found at the LTCB, identified as "HUT-78," for his initial attempts to infect a permanent cell line with suspected AIDS virus isolates....

p. 49. Meanwhile, Dr. Popovic renamed the parental cell line, changing the name from "HUT-78" to "HT." Drs. Popovic and Gallo claimed that the principal reason for the renaming was their uncertainty that the cell line which they cloned and with which they succeeded in growing the AIDS virus, was authentic HUT-78. Thereafter, in numerous scientific papers, talks, and internal memoranda, Gallo represented "HT/H9" and "H9" to be a new "discovery," a "breakthrough" accomplishment for the LTCB.

The evidence will show that Gallo knew or should have known that HUT-78 and HT were one and the same cell line...In fact, as the evidence will show, Dr. Gallo systematically misrepresented the origins of the HT cell line so that his fellow-scientists could not discern HT was really HUT-78. Consequently, Gallo's fellow scientists were not aware that HUT-78, a readily available cell line, was permissive for the AIDS virus, and they devoted considerable effort to attempting to obtain Gallo's cell line, upon which he placed onerous conditions for its use. See discussion infra.... 
p. 53. Significance of Gallo's Deviations from This Standard. Gallo's unattributed use and subsequent obfuscation of the identity and origins of the cell line he used to grow the AIDS virus is significant in at least three respects. First, Dr. Gallo's failure to identify the origin of $\mathrm{HT} / \mathrm{H} 9$ introduced a wholly unnecessary void in AIDS research, at the time as it is now, a particularly critical area of public health concerns. Second it denied other scientists immediate access to HUT-78, a readily-available cell line, while they delayed progress by securing, or attempting to secure, Gallo's "new" cell line.

Finally, Gallo's obfuscation/misrepresentation of the identity and origin of "his" cell line denied Dr. Adi Gazdar, the scientist principally involved in the discovery of the HUT-78 cell line, rightful recognition for his discovery. See Exhibit 1.

Numerous ORI witnesses will testify that it was a serious deviation from accepted practices for Dr. Gallo not to identify HT/HO as a derivative of HUT-78, or at least to disclose this possibility, both in the initial Science paper describing HT and H9 and in subsequent communications. 35

Footnote 35: Among the witness who will testify regarding the need to identify the origin of a cell line used in experiments and the impropriety of concealing that origin, are Dr. Schaffer, Dr. Curran, Dr. Richards and Dr. Tramont.

p. 57. 3. Dr. Gallo's Restrictive Conditions on Provision of the H9 Cell Line

(a) Factual background. Shortly after publication of the Popovic Science paper, in May 1984, numerous scientists contacted the LTCB, seeking to obtain both Gallo's infected cell line (H9/HTLVIIIB) and the uninfected cell line (H9). The uninfected cell line was particularly important, because it allegedly was a "new" cell line that was uniquely permissive for growth of the AIDS virus. Gallo's fellow scientists wanted to use the H9 cell line to attempt to grow their own AIDS virus isolates, to produce those isolates in quantity, and to initiate the numerous, varied experiments that were the obvious "next steps" in AIDS research, most of which required the existence of substantial quantities of HIV.

The evidence will show that despite clear standards in the scientific community that reagents should be freely distributed to responsible scientists, Dr. Gallo (1) refused outright to provide the uninfected H9 cell line to some researchers; (2) delayed providing the cell line for substantial periods of time for some scientists, while other scientists were promptly provided the reagents; (3) imposed restrictive conditions on the cell line to virtually all to 
whom he supplied it, with particularly onerous conditions for scientists not in his favor; and (4) otherwise gave preferential treatment to scientists whom he favored.

p. 58. Favoritism in Distributing the Reagents: The basic transfer agreement for receipt of either the infected or uninfected cell lines, developed at the LTCB, contained five conditions. Most of these were standard conditions related to safety and patent considerations. However, one of the conditions was decidedly non-standard: "Work performed will be on a collaborative basis with Dr. Gallo and his laboratory unless stated otherwise." Particularly favored scientists were not required to sign a transfer form (e.g. D. Zagury); other favored scientists had their transfer form annotated by Gallo himself (e.g., Dr. R. Weiss' form was annotated, "Collaboration at will for Dr. Weiss O.K. R. Gallo").

p. 61. Refusal/Delay in Providing Reagents: Gallo's treatment of certain of his PHS colleagues was particularly outrageous. For example, ORI will present evidence showing that on May 14, 1984, Dr. Malcolm Martin, a laboratory chief at the National Institute on Allergy and Infectious Diseases, NIH, requested the uninfected cell line from Dr. Gallo. Exhibit H-89. Although Dr. Gallo's practice was to review the requests on an almost daily basis, Dr. Gallo did not respond to this request until June 22, 1984. Dr. Gallo refused Dr. Martin's request, stating that it (the uninfected cell line) was "still being characterized." Exhibit H-102. Dr. Gallo also demanded to know what Dr. Martin intended to do with the uninfected cell line; Dr. Gallo explicitly stated that he did not want Dr. Martin to attempt to grow LAV in a cell line. Exhibit H-102.

Dr. Gallo said he would send Dr. Martin the infected cell line, and he sent to Dr. Martin a transfer agreement specifically designed for him. Besides the five conditions in the basic agreement, the agreement sent to Dr. Martin contained two additional, particularly outrageous conditions:

"Work with these reagents will not be published without prior approval by Dr. Gallo"; "Reagents will not be used in comparisons with other viruses."

ORI will show that these restrictions were part of an effort by Dr. Gallo to ensure that Dr. Martin would not be able to advance certain areas of research. Dr. Martin will testify regarding his interactions with Dr. Gallo on this matter. See also Exhibit H-18.

p. 63. Dr. Gallo waited over a month to respond to the CDC's request for uninfected H9. See Exhibit H-92. 
When Dr. Gallo finally provided materials to CDC-a sister PHS facility-the agreement included seven restrictions.... But Gallo imposed an even more obnoxious condition on CDC, i.e., not only did he tell the CDC scientists what they could not do with the infected cell line; he specified to CDC the only kinds of research it could do: "They (the reagents) will only be used for seropidemiologic studies and blood bank assays."

p. 64. Standards for the Sharing of Research Resources. ORI will prove that it was and is a commonly accepted practice within the scientific community that when a researcher has published research on a specific cell line, it is incumbent on the researcher to make the cell line freely available. These standards are reflected in numerous policies and publications. The National Academy of Sciences (The "Academy") specifically recognizes that "After publication, scientists expect that data and other research materials will be shared upon request.... [S]cientists should not deny requests for primary data because of professional jealousy." The Academy also acknowledged that proprietary interests of the scientist can be protected by the filing of a patent. ${ }^{44}$ Because Dr. Gallo had already protected whatever financial interests he might have had by filing a patent application, he had no basis for withholding the reagents from other researchers.

In 1989, the Institute of Medicine, Division of Health Sciences Policy, produced a report of a study by a committee on the Responsible Conduct of Research. Exhibit H-270. The panel recognized that "authors of published work have a traditional obligation to aid scientists interested in independent replication [including] ... access to the methods and reagents necessary for reproduction."...

ORI will present numerous witnesses that will testify that such a standard existed in the scientific community in 1984 and exists now. 45 The Richards Panel chastised Dr. Gallo's refusal to distribute uninfected H9 cell lines unless others entered into collaborative agreements:

Against the backdrop of comments from Gallo about the need for speed to counteract the growing AIDS epidemic, we note that the report states that Gallo refused to distribute uninfected H9 cells unless collaborative agreements had been secured from the other investigators ... we consider failure to distribute uninfected $\mathrm{H9}$ cells freely after publication of the article by Popovic et al. to be essentially immoral in view of the growing seriousness of the AIDS epidemic. 
p. 68. Dr. James Mason, formerly Director of the CDC and former Assistant Secretary for Health, will testify that so egregious was Dr. Gallo's refusal to provide his reagents to CDC scientists who had requested them that he was forced to intercede on behalf of CDC researchers whose requests for the cell line and other reagents had not been honored by Dr. Gallo.... ORI witnesses will testify that Dr. Gallo informed CDC staff that LTCB intended to delay sharing of the reagents until Dr. Gallo felt he had accomplished his own work with the reagents.

p. 69. Dr. Gallo's conduct was so antithetical to the mission of PHS and standards within the scientific community that, at a June 18, 1984 NIH AIDS Executive Committee Meeting, Dr. Wyngaarden specifically ordered Dr. Gallo to provide the uninfected cell line to Dr. Malcolm Martin and Dr. Walter Dowdle. Exhibits H-99, H-103.

pp. 70-71. Numerous witnesses will testify that Dr. Gallo's prohibition against other researchers who were provided the cell lines and reagents could not conduct comparisons of HTLV-IIIB with LAV was a restriction imposed by Dr. Gallo and not PHS. 54 ORI will present testimony that these restrictions were unprecedented and contrary to accepted PHS practices, and contrary to accepted practices for the conduct of research. 45

Dr. Gallo's restrictions on providing HIV reagents to the extramural community was noted by many members in the scientific community. Exhibit H-175. For example, the Dean for Academic Affairs for the Harvard School of Public Health noted the agreement "places unacceptable restrictions on research, is inconsistent with long-standing policies of this and many other major research institutions and threatens to inhibit vital research activity on a major threat to public health." Exhibit H-150. In response to this observation, Dr. Fischinger acknowledged that it would be "totally inappropriate" if there were any real strictures to the dissemination of research results in AIDS to other scientists and the public. ${ }^{56}$ Exhibit H-151.

... In addition to the witnesses identified above, Drs. Goldberger, Rall, Raub, Morgan and McGinnis will testify to the accepted norms of scientific practice for identification of unique cell lines and their availability to the scientific community and Dr. Gallo's deviation therefrom.

p. 72. Concerning Specifically the Statement Published in the Science Article: Dr. Gallo is charged by ORI with falsely re- 
porting that LAV had not been transmitted to a permanent cell line. Exhibit H-233. ORI will demonstrate that this sentence is embedded in a significant passage of the paper that is crafted in such a way as to be patently misleading. ORI will prove that this misrepresentation was material to the findings of the paper and was perpetrated in an attempt to distinguish falsely the LTCB's discoveries and to place the research of the LTCB inappropriately ahead of its perceived competitors....

p. 80. Thus, ORI will demonstrate that, not only had the LTCB transmitted LAV to a permanent cell line prior to publication of the Science paper, but the LAV virus had also been significantly characterized in several other laboratories, including the Pasteur, CDC, and the LTCB, prior to publication of that paper. Indeed, the Pasteur scientists made a number of scientific presentations (with Dr. Gallo present) and published several papers describing their characterization of LAV. See, e.g., Cold Spring Harbor presentation (Sept. 15, 1983) (paper handed by Dr. Montagnier to Dr. Gallo at this time); thus Dr. Gallo clearly had knowledge of this characterization. Exhibits H-027, 34; New York Academy of Sciences presentation (Nov. 14, 1983) (showing effect of LAV on Tcells and showing "Characteristics" of LAV in table 4); Park City, Utah, presentation by J.C. Chermann (at which Dr. Gallo was moderator) (Feb. 6, 1984) of "Characterization and Possible Role in AIDS of A New Human T-Lymphomatic Retrovirus," Exhibits H$44,44 \mathrm{~A} \ldots$.

p. 81. Similarly, ORI will show that contrary to Dr. Gallo's assertion in the Science paper, LAV had not been difficult to obtain in quantity. Indeed, the record will show that the Pasteur scientists produced the LAV virus in substantial quantities and supplied the LTCB with ample quantities of LAV upon demand prior to May 1984. See, e.g., Dr. Gallo's OSI submission (May 15, 1990), Att. LAV-6; Testimony of Drs. Chermann, Barré-Sinoussi, Montagnier, Francis and Martin....

p. 83. Accordingly, ORI will establish that the statements in the Science paper by Dr. Gallo that LAV had been insufficiently characterized, had not been transmitted to a permanent cell line, and had been difficult to obtain in quantity are misleading and false. Indeed, ORI will show that Dr. Gallo knew these statements were misleading and false when he inserted them into the paper. Therefore, his actions constitute scientific misconduct....

p. 86. The drafts of the Popovic paper are highly instructive with respect to the nature and intent of Dr. Gallo's actions in 
writing the disputed paragraph. Exhibits H-48-56, H-72. All available drafts, including those drafts that Dr. Popovic retrieved from his sister in Austria, will be submitted as evidence. The various drafts of the Popovic paper will be introduced to reflect the evolution of the controversial statement. The drafts reveal a steady diminution in the attribution afforded the Pasteur and the role of LAV in the LTCB'S AIDS research. The successive drafts reveal Dr. Gallo's apparent increasing determination to exclude references to LAV, a determination that eventually culminated in the false and misleading statement regarding LAV selected by Dr. Gallo for the final version of the paper.

p. 87. ... Draft 2 states in relevant part: “... LAV as a reference virus (gift from Dr. L. Montagnier) has been used in the first series of experiments. Two cell lines with characteristics of mature T-cells showed a susceptibility to the virus infection as determined by reverse transcriptase (RT) assay...The infected parental cell line exhibited positivity for particulate reverse transcriptase activity in culture fluids...."

... Draft 4 reflects substantial changes by Dr. Gallo. Significantly, Dr. Gallo struck through the reference statement above acknowledging the use of LAV in Dr. Popovic's cell line experiments. Dr. Gallo's handwritten note beside the deletion of the references to LAV states: "Mika, you are crazy."... Similarly, Dr. Gallo deleted a statement by Dr. Popovic that LAV “... is described here as HTLV-III."

p. 88. Additionally, Dr. Gallo fundamentally altered the description of Dr. Popovic's initial LAV experiments. These first experiments were actually conducted using two cell lines (Ti7.4 and HUT78). However, Dr. Gallo changed the description to a single cell line. In order to obscure the cell lines further, Dr. Gallo altered the identifying information on this cell line from a patient with Sezary Syndrome, an identifier that would likely clue the reader that the "new" cell line was actually HUT78, to a patient with ATL.

p. 90. In Draft 8, the references to LAV's being a gift from Drs. Montagnier and Chermann of the Pasteur as well as the acknowledgment that LAV was grown in HT and has similar cytopathic effects are deleted. The sentence referring to LAV's characterization is modified to read, "however, it is possible that this is due to insufficient characterization because of poor virus production." Furthermore, the final sentence is truncated to eliminate the clause "and for the resolution of HTLV-III and LAV." 
p. 91. ORI will prove that the progression of changes Dr. Gallo made to the Popovic paper demonstrates a continuation of his efforts to obscure the use and significance of LAV in the LTCB's research.... Dr. Gallo's efforts to obfuscate the truth will be further demonstrated by a review of Dr. Gallo's varying explanations for the false statements, explanations he apparently jettisoned by settling upon the explanation $d u$ jour that he was referencing the French peer reviewed published literature. ${ }^{76}$...

\section{p. 97. ORI WITNESSES}

Drs. Goldberger, Rall, Morgan, Raub, Huth, Richards (and other members of the Richards Panel), Schaffer, and Woolf will testify regarding the acceptable standards in the community and $\mathrm{NIH}$, what constitutes a serious deviation from those standards and why Dr. Gallo's conduct amounts to scientific misconduct.

Drs. Martin, Cabradilla, Francis, McGrath, Chermann, Montagnier, Barré-Sinoussi, Schaffer, and Hadley will testify about the growth of LAV in the Pasteur and the LTCB and Dr. Gallo's awareness of the growth of LAV in the laboratory.

Drs. Cabradilla, Francis, Murphy, Martin, Chermann, BarréSinoussi, Montagnier, Kalyanaraman, Schaffer, and McGrath will testify as to Dr. Gallo's knowledge of the significant characterization of LAV and its availability in large quantities at the time the Science paper was submitted.

Drs. Chermann, Barré-Sinoussi, Martin, Francis, Cabradilla, McGrath, and Schaffer will testify that the statement at issue is both fallacious and clearly misleading.

\section{Applicable Standards of Conduct}

For each allegation set forth above, ORI will prove by a preponderance of the evidence:

A. The applicable standard of scientific conduct in existence at NIH in 1983-84 for a scientist in Dr. Gallo's position;

B. That Dr. Gallo's conduct seriously deviated from that standard;

C. That such conduct was not due to honest error or honest differences in interpretations of data; and

D. That such conduct constitutes scientific misconduct.

In addition to the various witnesses and documents previously identified, ORI will call the following witnesses to testify on these four issues: Drs. Schaffer, Hadley, McGinnis, Bivens, Goldberger, Huth, Woolf, Francis, and Martin. 


\section{CONCLUSION}

Based on the foregoing., ORI submits this Offer of Proof that Dr. Gallo committed scientific misconduct as described in the following allegations:

A. Allegations A1, A2, A3, A4, and 8 in the aggregate, or any combination thereof that includes allegation 8 .

B. Allegation 8 alone. The facts underlying allegations A1-A4 are clearly relevant to, and will be used to prove, a pattern of conduct by Dr. Gallo showing an intent to deceive in allegation 8.

C. Allegation A4 alone. The facts underlying allegations A-A3 and 8 are clearly relevant to, and will be used to prove, a pattern of conduct by Dr. Gallo showing an intent to deceive in allegation $\mathrm{A} 4$.

Respectfully submitted,

Nancy Morrison O'Connor

Marcus H. Christ, Jr.

Debra M. Parrish

COUNSEL FOR THE OFFICE OF RESEARCH INTEGRITY

Of Counsel:

Chris B. Pascal

Office of the General Counsel

Public Health Division'

Office of Research Integrity Branch

5515 Security Lane, Suite 700

Rockville, MD 20852 


\section{INTERLUDE: MOTIVES, INTENT, AND MISCONDUCT}

I shall now add my own comments on "motives and intent," as well as "misconduct." Both in the Baltimore and the Gallo cases questions of motives, intent, and misconduct were brought up. Notably, the HHS-ORI Report of 30 December 1992 dealt repeatedly with Gallo's "intent" in dealing with the French AIDS virus. For example, concerning the statement in the paper for which they charged Gallo with "misconduct," this report stated: "Gallo intended the statement to deceive others regarding the growth of LAV."

On the other hand, the Appeals Board issued the ruling: "The key issue here, however, is whether Respondent reasonably could have anticipated at the time of the alleged conduct that such conduct, if proved, would constitute 'scientific misconduct.'... Even assuming Respondent engaged in the alleged conduct, this fact alone would not impugn Respondent's research integrity. If this integrity is not impugned by the conduct, no administrative action to protect the federal government interest is needed or appropriate; and applying the label to Respondent in such circumstances would be fundamentally unfair."

This ruling of the Appeals Board is quite remarkable in several ways. For example, suppose the following conditions prevail systematically in the laboratory of a scientist working for the government:

- the scientist does not keep proper laboratory notebooks;

- the data accumulated by the scientist are so confused, or sloppy, or unkempt that they are unverifiable; and

- descriptions of experiments by the scientist are so vague or not determinable (for whatever reason) that the purported results are uncheckable, and it is not even clear what factors entered into the experiment. 
A major question as I, and certainly some (how many?) other scientists see it, is not whether to apply "the label" of "scientific misconduct" to a person. Rather, we ask the question whether defective scientific practices are to be tolerated.

Of course, accidental mistakes may occur. They happen to all scientists, as we all know. When is a "pattern of behavior" sufficiently systematic to merit administrative action (which one?) by persons ultimately responsible for laboratories, or to merit censure by scientists? The answer, as far as I am concerned, is not a matter for legal adjudication. It is a matter for open discussion, based on the public availability of facts, which I expect to be made available through suitable investigations by the agencies on which the laboratories depend.

As much as I agree with the ORI Report and the Richards Panel that Gallo's misrepresentations denying credit to the French could not be tolerated by the scientific community without expressing some objections on the record, I do not agree that the determination of motives or intent is necessary to evaluate a professional performance. Persons have a way of adjusting their psychology so that intent and motives are perceived differently by themselves or others at different times. ${ }^{1}$ Going into motives or intent results in a morass of differing interpretations and psychological analyses according to diverse views of psychology. As a result, going into motives and intent detracts from looking at facts.

Similarly, I object to tying the entire investigative enterprise to a determination of "misconduct" rather than a determination of facts in the case, with the result that if no "misconduct" in the above legalistic sense is found, then "no administrative action is needed." Linking the investigative process to a determination of "intent" or "misconduct" obfuscates the possibility of determining and making clearly known the facts of the case. Actually it has been documented to destroy this possibility in certain important aspects.

The ORI Report did not need to go into "intent" to determine that Gallo did something which would not be tolerated by HHS. Indeed, as far as I am concerned, the ORI Report and memoranda within NIH gave facts which do not need to be supplemented with a determination whether there is "intent" or "misconduct," but these facts often got lost in the shuffle, as when for instance

\footnotetext{
${ }^{1}$ The ORI Report was criticized by others for dealing with "intent." Science (8 January 1993) reported: "Former OSI Director Jules Hallum, an investigator on the Gallo case, says, 'the ORI Report is filled with statements about what Gallo intended. How did they get into his mind?"
} 
Nicholas Wade in the New York Times represented Gallo as a martyred saint. Some of these facts, among others, are:

- that in successive versions of the paper, sentences written by Popovic were deleted by Gallo and replaced by successively weaker attribution of credit to the Institut Pasteur;

- that Gallo made contradictory statements in explaining what he had done; and

- that the viruses called HTLV-IIIB and MOV in Gallo's laboratory were actually the French virus, and that these viruses were used in the patent application for the blood test.

I don't see the need to go beyond facts and into "intent" to evaluate Gallo's performance.

What is "misconduct" anyhow? At which point are people ready to use words such as "fraud" or "misconduct" to describe certain actions? At different points for different people at different times in different circumstances, of course. But why link the questioning of experiments and data to charges of intent or motives? There are many forms of conduct which are undesirable in science:

- reporting data selectively, or fudging data in various ways, for instance: data are not recorded, or are kept in such a disorganized and messy fashion that they are unverifiable, and later a reconstructed version is presented as the original data;

- falsifying data, or reporting on experiments which were not made;

- not giving sufficient credit to the work of others, which can take many forms, including plagiarism, or using someone else's results in applying for a commercial patent;

- refusing to acknowledge mistakes or to make corrections;

- refusing the responsibility of checking the reliability of your own data;

- leaving to others the responsibility of establishing the validity of what you have published; and

- ad lib.

We find the determination of "intent" and "motives" as substitutes or principal criteria for evaluating performance both in the Gallo and in the Baltimore cases. The New York Times of 6 October 1990 quoted Dr. Streicher, "a spokesman for Dr. Gallo," as saying: "There was no need to use the French strain, and therefore there was no intent to commit any misconduct. That makes 
the ethical question moot." I question Streicher's reference to "need." Need for what? To grow the so-called "AIDS virus" continuously in a cell line? Existing documentation indicates there was such a need. I object to the logic of Streicher's "therefore."2

When the Appeals Board issued its rulings, it rendered moot the ORI Report, and shifted the focus of attention from science to legalisms. Facts about the case, whether those available or those withheld by NIH and HHS, became secondary. We shall analyze this aspect further in connection with the decision of the U.S. Attorney not to prosecute, following the HHS Inspector General's investigation.

It is for the scientific community to decide whether to accept a deterioration of standards, or to stand firm against such a deterioration.

Therefore:

Rather than looking into motives and intent, and determining "misconduct" in some legalistic sense, let us raise questions about performance concerning:

- what was achieved, when and by whom;

- the accuracy, truth, or falsity of statements about scientific work or about the history of scientific work; and

- the level and standards of performance in carrying out scientific work.

I urge that questions about conduct concentrate on facts concerning performance, and not on arguments as to what constitutes "fraud," "intent," or "misconduct" and how these words are to be used. Once facts are established, the scientific community can arrive at de facto decisions: whether to tolerate certain practices or not, whether to fund certain laboratories or not, whether to rely on claimed results by certain persons or not. But even though one does not wish to tolerate a practice, this does not imply that the practice has

\footnotetext{
${ }^{2}$ Streicher's type of argument was also used in the Baltimore case. For instance, in the 9 June 1990 Economist we find: "But she [Imanishi-Kari] has put forward one argument eloquently, which Dr. Baltimore has sympathetically repeated: what possible motive could she have to cheat?... If scientists were other than human, this might be a good argument. If scientists had not in the past invented data to support conclusions that they believed, but could not yet otherwise prove, it might have some weight. But they are human, and it has happened before."
} 
to be labeled fraud or misconduct. It does not imply that the practice has to give rise to legal or quasi-legal proceedings. Rather, let us have official reports clearly informing us of the facts in the case. 


\section{THE DINGELL SUBCOMMITTEE HEARINGS OF 21 JULY 1993}

I reproduce in full below the opening statement by Dingell at the hearings for Lowell T. Harmison.

\section{OPENING STATEMENT OF \\ THE HONORABLE JOHN D. DINGELL, CHAIRMAN SUBCOMMITTEE ON OVERSIGHT AND INVESTIGATIONS WEDNESDAY, JULY 21, 1993}

The hearing today is part of a Subcommittee investigation that bears directly on the integrity of public service and the integrity of the scientific enterprise.

In April 1984, the U.S. Government announced with great fanfare that government scientists had discovered the virus that was the cause of AIDS and developed a blood test to detect antibodies to the virus. These developments were heralded by Health and Human Services (HHS) officials at the news conference as "a triumph of science" and "another miracle" added to "the long honor roll of American medicine and science." Eventually, the U.S. Government received a patent on the blood test; numerous other related patents were applied for and received.

No sooner was the HHS announcement out than suspicions followed by outright concerns, were heard to the effect that:

(1) the U.S. Government scientists' supposed "discovery" was not their own; these scientists actually "discovered" another scientist's virus and used it for their putative breakthrough; and

(2) the U.S. Government had engaged in "inequitable conduct" before the United States Patent and Trademark Office, having seriously failed in its duty of disclosure to that office.

In 1985, these matters erupted into a full-blown patent dispute, a dispute that extended for nearly two years, through no less than four legal proceedings, culminating in a negotiated settlement. This settlement has come under increasing criticism as its 
factual underpinning have evaporated.

Even after the settlement, the controversy did not die. Within the scientific community, there were continuing concerns about possible improper conduct in the National Institutes of Health (NIH) laboratory of Dr. Robert Gallo. Significant questions about what information was provided to-and withheld from-the U.S. Patent Office remained unresolved. And it was not long until evidence began to appear that strongly challenged U.S. Government actions during the patent dispute.

Today, as the Subcommittee nears the end of its investigation of this matter, an investigation hindered and greatly prolonged by continued obstructionism at the NIH and elsewhere, there is substantial evidence of problems in, and there are serious concerns about, the government's handling of the matter:

(1) It is now clear that the virus used to make the United States HIV antibody blood test is the virus discovered by scientists at the Institut Pasteur. Moreover, the cell line used to grow the virus was the cell line discovered by a scientist at yet a third laboratory. After years of denial, it is absolutely clear that both the virus and the cell line that were claimed as new discoveries of the U.S. Government scientists were actually those of other scientists and merely given new names.

These are not the Subcommittee's judgments; they are the judgments of the scientific community. In the case of the virus, the findings were confirmed in a paper published in the prestigious journal Nature, just a few weeks ago.

(2) When the U.S. Government sought a patent on its alleged "discoveries" relative to the HIV blood test, officials apparently withheld from the U.S. Patent Office information directly and materially relevant to the examination of the Government's patent applications-information showing the claimed invention actually had been made long before by other scientists.

(3) Senior HHS officials, as well as HHS and DOJ attorneys, apparently possessed evidence at the time of the patent dispute that, at a minimum, pointed to very serious doubts that the U.S. Government's patent claims could be substantiated. But international prestige and significant financial rewards apparently made defense of the U.S. patent paramount. Consequently, these U.S. Government officials may have willfully ignored and, in some instances, actively suppressed that evidence.

Also, as the Subcommittee investigation has proceeded, we have encountered repeated instances of obfuscation and obstructionism on the part of past and current Government officials that suggest a certain reluctance to confront the facts. Documents 
have been destroyed. Documents have been withheld for protracted periods. In several instances, the documents known to exist have never been produced from the official files. And some witnesses have refused to appear voluntarily.

The hearing today is necessary only because Dr. Harmison, a key figure in the events under review, has chosen not to cooperate with a Subcommittee request for a staff interview. This lack of cooperation has not been tolerated in the cases of the Environmental Protection Agency or the Department of Defense witnesses in the past and it cannot be ignored in this instance.

The Subcommittee is at a loss of understand why routine cooperation was not possible here, and the absence of a staff interview creates a great deal of uncertainty as to what information will be received today. Because of this uncertainty, and out of an abundance of caution, without objection the Subcommittee determines that the testimony "may tend to defame, degrade, or incriminate any person" and, under Rule $\mathrm{XI}(2)(\mathrm{k})$ of the Rules of the U.S. House of Representatives, the hearing will be closed to the public. The chair notes that a quorum to take testimony is present, as required by that rule. Other Members will be recognized for opening statements and then there will be a brief recess to clear the room. After that we will proceed to administer the oath to Dr. Harmison and receive his testimony. 


\section{THE HHS INSPECTOR GENERAL, THE U.S. ATTORNEY, AND THE IG'S MEMORANDUM}

According to Suzanne Hadley who headed the NIH-OSI Gallo investigation before being forced out by Bernadine Healy, the OSI did not consider questions having to do directly with the patent application, because OSI was advised by the HHS Office of the Inspector General that such questions might require a criminal investigation. Similarly, the ORI did not consider such questions.

\section{No Prosecution}

The Inspector General did carry out an investigation. It found sufficient cause to present a case to the U.S. Attorney's office in Baltimore, MD. In January 1994, the U.S. Attorney's office declined to prosecute the case, and wrote a letter dated 10 January 1994 to the HHS Inspector General to inform the IG of the U.S. Attorney's position.

This letter addressed several issues: legal technicalities and legal concerns, the previous history of the ORI case, the validity of the ORI case, the legitimacy of the patent application, the legitimacy of the royalties, and responsibilities on a broader basis (HHS, the scientific community, the government, and the "court of public opinion"). I shall now give a summary of the letter.

(a) Legalistic reasons for the U.S. Attorney's office not to prosecute. The letter gave an account of those reasons. It stated that "... certain procedural rules governing criminal prosecution prohibit us from prosecuting many of the alleged false statements and other conduct of Drs. Gallo and Popovic, no matter what we might think of the relative merits of such a prosecution."

- Statute of limitations. After mentioning some of the "possible crimes" under consideration, such as making a false statement, 
obstruction of justice or agency proceedings, and perjury, the letter invoked "the statute of limitations which bars prosecution for any such conduct which occurred prior to December 1988, which includes almost all the statements at the core of this case."

- Lack of jurisdiction. The letter stated that "several of the statements allegedly made by either Drs. Gallo and/or Popovic were made in the District of Columbia, and are therefore beyond our consideration for individual prosecution." Aside from that, the U.S. Attorney also recalled that "the U.S. Attorney's Office for the District of Columbia previously considered, and declined, prosecution" when the HHS Inspector General's office presented the case to them previously.

- Royalties on the patent for the blood test. Concerning the royalties, the letter stated: "Any such prosecution, such as for mail fraud ... or conspiracy to defraud the government ... would require the government to prove beyond a reasonable doubt that Drs. Gallo and Popovic knowingly and willfully devised a scheme to defraud the government of its property by means of false statements and representations. However, when the patent relating to the AIDS test was applied for in 1984, neither Drs. Gallo nor Popovic were entitled to share in the royalties for the discovery, nor could they have known at the time that the Technology Transfer Act of 1986 would authorize such payments ... we have also considered the investigation and report of the patent firm of Allegretti and Witcoff, which independently conclude that Dr. Gallo's statements in connection with the patent dispute were not 'prima facie' false, but rather subject to varying interpretations. Moreover, even the Office of Research Integrity acknowledged that any allegedly false statements were 'minor'; and did not invalidate the underlying research. Thus we do not believe we would be able to sustain our burden of proof to demonstrate several important elements of any federal offenses relating to the receipt of royalty payments."

- "Reasonable doubt." After noting the above obstacles to prosecution, the U.S. Attorney's letter also stated that the U.S. Attorney "was not satisfied that there is a substantial likelihood of convincing a jury beyond a reasonable doubt that either Dr. Gallo or Dr. Popovic acted with the requisite criminal intent."

- The Appeals Board decision and ORI's dropping the Gallo case vis-à-vis the Appeals Board. Finally, the U.S. Attorney's letter brought up the fact that in facing the Appeals Board, the ORI "was unable to meet a far lesser standard of proof, that of preponderance of evidence or $51 \%$ in its effort to convince the Board that Dr. Popovic's conduct involved intentional false statements." 
The letter stated explicitly that the U.S. Attorney "could not ignore the conclusion reached by those independent arbiters" concerning the Popovic case, and also could not ignore "the decision of the ORI to forego even the presentation of evidence regarding the alleged misconduct of Dr. Gallo, some of which was independent of the actions of his subordinate Dr. Popovic."

However, the U.S. Attorney's letter did not stop with such legalistic considerations. It brought up two other kinds of issues.

(b) HHS responsibility in regards to the royalty payments. The letter stated: "Our decision not to seek prosecution of Drs. Gallo or Popovic does not mean that we believe they should continue to receive their annual royalty payments. On this issue, we express no opinion other than to observe that Dr. Gallo, as of approximately May 1991, has acknowledged that it was the French Institute Pasteur sample sent to his laboratory which formed the basis for the AIDS test. Whether he and Dr. Popovic should continue to receive their royalties under such circumstances, or whether the government should make any effort to recoup any payments made to them since then, are matters which are more appropriately addressed by the Department of Health and Human Services."

(c) General considerations of responsibility. The final part of the prosecutors' letter to the HHS Inspector General addressed general considerations of responsibility. I quote the last paragraph fully. "In deciding not to seek prosecution, we recognize that this case transcends the normal type of criminal case, and that the conduct of these two noted scientists reflects upon the integrity of the scientific process, the National Cancer Institute, and indeed the conduct of our government as a whole. However compelling is the need to provide a forum for historical accuracy on these issues, that noble desire cannot be a substitute for evidence, nor does it justify using the criminal courts in place of the court of public opinion."

Thus the letter from the U.S. Attorney to the HHS Inspector General in its last two sections threw back the Gallo case partly to HHS and partly to the scientific community.

In addition, an article by John Crewdson in the Chicago Tribune (see below) reported that, "Officials close to the case said the evidence gathered by the Inspector General, including thousands of pages of documents and interviews with some two dozen witnesses, would now be provided to the House Subcommittee on Oversight and Investigations, which is also investigating the 
case...."

Thus the Gallo case was also thrown back to the Dingell Subcommittee.

\section{§2. Press Reports}

The letter from the U.S. Attorney to the HHS Inspector General was not reported in the New York Times. It was reported in the informative Crewdson article "U.S. declines to prosecute AIDS researcher Gallo" (Chicago Tribune, 21 January 1994, p. 1). Crewdson's article was approximately 3,800 words long, and provided extensive quotes from the letter, and mentioned its multiple points. Some accounts of this letter were also given in Science ("Feds Drop Gallo Criminal Probe," ScienceScope, 28 January 1994 p. 459), and Science and Government Report ("Saint or Scoundrel? The Gallo Controversy Goes On," 1 February 1994, p. 6). As a result, two things happened:

- On 1 February 1994, I wrote to the HHS Inspector General's office to get a copy of the letter from the U.S. Attorney, under the Freedom of Information Act. On 6 April 1994, I received a reply that this item (and others I had asked for) "which are part of an open and on-going investigation are exempt from mandatory disclosure under the FOIA [Freedom of Information Act] by exemption (b)(7)(A)."

- On 14 March 1994, I wrote to Science editor Ellis Rubinstein to ask him for a copy of the above letter, because we had corresponded about this letter, and he had sent me some quotes from it, without sending me the entire letter. On exactly the same day that I received the notice from HHS that they could not disclose the letter, I received a copy of the letter from Ellis Rubinstein.

These two simultaneous events document the extent to which we live in a Kafkaesque world.

The ScienceScope piece "Feds Drop Gallo Criminal Probe" (Science, 263, 28 January 1994, p. 459) was approximately 300 words long, and reported the refusal of the U.S. Attorney to prosecute. It stated unambiguously: "Rather than exonerate Gallo, however, the prosecutors pegged their decision to legal hurdles." This piece mentioned briefly some of the reasons the U.S. Attorney gave for the refusal to prosecute, and the next to last paragraph of the ScienceScope piece was: "Contacted by Science, Gallo said he was 'frustrated' that the prosecutors said they halted the probe due to technicalities rather than a lack of evidence of wrongdoing. 'My reputation is everything,' he says. 'I still 
have no public forum to clear my name."

Nowhere in that piece did Science even allude to the fact that portions of the U.S. Attorney's letter to the HHS Inspector General dealt with the broader issue of responsibilities, as mentioned in $\mathbf{\$ 1 ( b )}$ and $\mathbf{8 1 ( c ) . ~ T h e ~ r e p o r t i n g ~ b y ~ S c i e n c e ~ w a s ~ s e l e c t i v e ~ i n ~ t h e ~}$ following manner:

- Readers could not learn from Science that the prosecutors had expressed concern with more than "legal hurdles" and "technicalities."

- Science brought to the fore Gallo's complaint about a lack of "forum" to clear his name, while at the same time Science did not mention the "forum for historical accuracy" and the "forum of public opinion" brought up by the prosecutors.

- Science did not mention the existence of passages in the U.S. Attorney's letter noting that Gallo acknowledged three years ago that the virus which he and Popovic used to develop the blood test was the French virus. In particular, there is no mention of any sentence such as the one stating: "Whether [Gallo] and Dr. Popovic should continue to receive their royalties under such circumstances, or whether the government should make any effort to recoup any payment made to them since then, are matters which are more appropriately addressed by the Department of Health and Human Services."

- Science did not give the information that the U.S. Attorney's letter stated: "In deciding not to seek prosecution, we recognize that this case transcends the normal type of criminal case, and that the conduct of these two noted scientists reflects upon the integrity of the scientific process, the National Cancer Institute, and indeed the conduct of our government as a whole."

The last paragraph of the ScienceScope piece, coming immediately after the Gallo quote about the lack of a "public forum to clear" his name, stated: "One ordeal remains for Gallo: Representative John Dingell (D.-Mich.) is expected to release a report on the Gallo case in May." This paragraph represented a specific point of view at the expense of others. Indeed, a question which may arise for some scientists (including me) is not whether "one ordeal remains for Gallo," but whether there will finally be made public documentation about the HIV blood test patent application and the behavior of the U.S. Government in this connection. There is also the issue of NIH withholding information over several years, and NIH stonewalling Dingell's request for information and documents pertaining to the patent application and what 
went on in Gallo's laboratory. To me certainly, whether the truth about these events is an "ordeal" for Gallo is a secondary matter.

Furthermore, Science did not report, as Crewdson did in the Chicago Tribune, that the HHS's Office of the Inspector General would provide thousands of pages of documents and interviews to the House Subcommittee on Oversight and Investigation. Therefore Science did not provide relevant information, and reported the "expected" release of Dingell's Report in a manner which slanted the issues concerning the integrity of NIH and the government.

Readers are affected differently, according as Science reports issues one way or another. Scientists' reactions and the way they exercise their responsibilities are also affected very differently depending on whether they are, or are not, informed of the broader concerns of the U.S. Attorney.

\section{§3. Some of My Conclusions}

The engagement of the HHS Inspector General in a "criminal investigation" rather than in the dissemination of accurate information (establishing a "forum for historical accuracy"), so that the "court of public opinion" could operate in an informed way, had major consequences. At the very least:

(a) Much information was withheld, certainly from the public and especially from scientists outside the government, but also possibly from OSI and ORI themselves. For instance, did OSI and ORI have available the "thousands of pages of documents and interviews with some two dozen witnesses" when they were doing their own investigations? The supposedly non-legal offices OSI and ORI of HHS did not consider the matter of the patent application because originally the HHS Inspector General's office thought it involved questions which might give rise to prosecution, so there arose a Catch-22 situation, one of whose effects was to prevent some information from reaching scientists, let alone the public. Questions which OSI and ORI claimed could not be settled on the basis of evidence which they had available might have been settled if they had the evidence gathered by the Inspector General, but kept from them for legal reasons.

As a result of a legalistic approach, official and clear answers were not provided to a number of specific questions which had been raised about the patent application. It was, and still is, the responsibility of HHS, of the scientific community (especially of the Richards Panel), and of Dingell's Subcommittee to provide 
documented answers.

(b) The U.S. Attorney's decision not to prosecute provided an internal contradiction in the attempts by various segments of the government to shed light on the events of the Gallo case. As far as I am concerned, this decision showed in a spectacular way the bankruptcy of some attempts to resolve certain questions of scientific responsibility via the legal system. I repeat here the warning of Paul Doty, already quoted in connection with the Baltimore case (Nature, 18 July 1991, p. 183):

But the essence of change must come within the scientific community by its reassertion of its ability to police itself.... This challenge to readdress the fundamental tenets of acceptable behavior in science comes at a time when the traditions of the scientific enterprise are under new threats arising from new stresses and temptations ... all these contribute to the pressure to compromise and erode the high principles of the past. As a result the scientific community may already be experiencing a gradual departure from the traditional scientific standards; this could be abetted to condoning the behavior seen in this present case. In this way we risk sliding down toward the standards of some other professions where the validity of action is decided by whether one can get away with it. For science to drift toward such a course would be fatal-not only to itself and the inspiration which carries it forward, but to the public trust which is its provider."

How would HHS, NIH, the scientific community, and the Dingell Subcommittee, meet their responsibilities from now on?

\section{\$4. The IG's Memorandum}

Even though the prosecution requested by the Inspector General's office did not take place, the IG issued a 35-page memorandum which surfaced in some of the press, for instance:

"A Parting Shot From a Closed Case," by Jon Cohen, Science Vol. 265, 1 July 1994, p. 24.

"U.S. inquiry discredits Gallo on AIDS patent," by John Crewdson, Chicago Tribune, 19 June 1994, p. 1.

As far as I was able to determine, the IG's memorandum was 
not covered by the New York Times. It was only mentioned incidentally in the New York Times' article on the patent revision (see XVI, §3).

The IG's memorandum was very negative toward Gallo. It deals mostly with the patent application, although it also recalls false statements made by Gallo throughout the eighties. I shall quote one example from the memorandum dealing with the patent application, since we have not discussed the patent application so extensively elsewhere.

Excerpt from the IG's Memorandum, 10 June 1994. During 1986, the [patent] examiner rejected the pending claim in several Gallo et al. follow-on-applications ... on grounds that the work of the IP [Institut Pasteur] scientists was "prior art" to Gallo et al....

The relevance of the IP work to that of Gallo et al. was affirmed by the PTO [Patent and Trademark Office] examiner, when she became aware of it. The examiner advised the OIG [Office of the Inspector General] that, had she been aware of the IP prior art at the time she examined the blood test application of Gallo, she would have suspended prosecution of the Gallo application and declared an interference between the two applicants.

Gallo's lawyer Joseph Onek, on behalf of Gallo, wrote a letter to the Inspector General June Gibbs Brown on 23 June 1994, stating:

"The investigative memorandum of June 10, 1994 concerning Dr. Robert Gallo and Dr. Popovic is filled with an extraordinary number of errors reflecting deliberate factual distortions, scientific illiteracy and obvious bias. The most significant errors are as follows:"

There followed 12 items. Onek also wrote that the memorandum was a "disgrace" and "should be withdrawn immediately."

I shall give here an example of a false statement by Onek to allow readers to form a more informed opinion. I find this example the easiest to understand of many such examples, because it requires no knowledge whatsoever of the Gallo case and its history. The matter has to do directly with an item that is in the IG's memorandum, and the flat assertion by Onek that this item is not there. Who is making "errors" and "factual distortions"? 


\section{A FALSE STATEMENT BY GALLO'S LAWYER}

From Onek's letter of 23 June 1994 to the HHS Inspector General, item 3, p. 2: The [IG] memorandum never mentions that HIV-Lai contaminated LAV Bru at the Pasteur....

From the IG's memorandum, p. 15. Gallo's records show the following reagents were sent from the IP to the LTCB in 1983:...

p. 16. Two shipments of LAV virus-in July 1983 and September 1983. The September 1983 shipment of LAV contained two samples with different identifiers; however, both examples were believed to contain the same virus, from patient BRU. In reality, as demonstrated in 1991 by Wain-Hobson et al. [Science; 252, pp. 961-965] and confirmed by the Roche analyses, in 1993 [Nature, 1263, pp. 466-469] one of the September LAV/BRU samples had been accidentally contaminated at the Institut Pasteur and overgrown with LAV/LAl; consequently, in September 1983, Gallo et al. received one sample each of LAV/BRU and LAVILAI.

Therefore Onek's statement is false, in a particularly striking and obvious way. I shall give more similar examples in XVI, 84 .

The false statement by Onek is especially grave, because Onek questioned the motivation of the Inspector General by commenting: "The failure of the OIG to mention these accidental contaminations demonstrates its total bias and its unrelenting effort to disparage Dr. Gallo's contention that the similarity in HIV-Lai and III-B is best explained by an accidental contamination in both laboratories." So what does Onek's false statement "demonstrate"? To whom?

As a scientist, Gallo is responsible for the lawyer's statements issued on his behalf, and for correcting these false statements. To my knowledge, he has not done so. Conversely, the scientific community is entitled to hold Gallo responsible for the statements made by his lawyer on his behalf.

Onek also objected that the IG's memorandum "never mentions that, as the Office of Scientific Integrity made clear, Dr. Gallo's laboratory had another isolate, HIV-RF, which could have been 
used for the AIDS blood test. (Indeed, Dr. Popovic recommended that it be so used.) The existence of RF removes any motive for Dr. Popovic or Dr. Gallo to misappropriate the French virus and strongly supports the contention that the similarity of III-B and HIV-Lai is the result of an accidental contamination."

(a) We have already dealt in detail with the point about the isolate RF in our discussion of the OSI Report (V, §3). Gallo's lawyer actually was continuing a line first promoted in William Raub's press conference of 5 October 1990, that the existence of certain "isolates" in Gallo's laboratory were somehow exculpatory, or showed that Gallo had no motivation to appropriate the French virus. (Cf. the discussion in III.)

(b) The second half of the sentence, concerning an "accidental contamination," again contains an unjustified innuendo. Of course, the sample of what was thought at the time to be LAVBru was contaminated by LAV-Lai at the Pasteur Institute, as stated in the IG's memorandum. However, the point made in the IG's memorandum (and made by others throughout the case) is that Gallo used the French virus for his blood test, whatever patient this virus came from (Bru or Lai). For purposes of determining whether Gallo used the French virus, it is irrelevant whether this virus came from one patient or the other.

The rest of Onek's points can be analyzed similarly in light of the documentation, and thus can be shown to be without merit at best, or outright false. Having worked out several examples, I leave others as exercises for the reader. Of course, by issuing false statements and misrepresentations via his lawyer, Gallo succeeded in accumulating complications which caused more and more exchanges, and made it increasingly difficult for people without the appropriate background or stamina to determine the truth.

As usual, I am especially interested in the way exchanges such as the one between the IG and Onek-Gallo are handled in the scientific press. The article by Jon Cohen in Science reporting on the IG's Report started: "The latest headline grabbing investigatory report in the case of Robert Gallo and the discovery of the AIDS virus reads like a brief for the prosecution in a scientific fraud case against the National Cancer Institute researcher." I would describe the IG's Report as a carefully and meticulously documented account of Gallo's misrepresentations over the years.

Jon Cohen quoted uncritically the sentence from Onek to the effect that the IG's memorandum "is filled with an extraordinary number of errors, reflecting deliberate factual distortions, scientific illiteracy and obvious bias." Cohen also quoted Onek's 
statement that the memorandum was a "disgrace" and "should be withdrawn immediately." Cohen made a special point of systematically and uncritically contrasting assertions from the IG's Report with objections raised by Gallo's lawyer Joseph Onek, in the letter to the Inspector General. He did mention that Onek did not address the statement I reproduced from the patent examiner, but otherwise he uncritically repeated Onek's objections.

In particular, Science did not inform its readers of the existence of false statements such as the one $I$ have reproduced above or of the other example I shall give in XVI, \$4. Thus Science misinformed its readers by a defective analysis of what Onek wrote. Readers for the most part do not have original documents in hand, and even if they do, they may not have the time or inclination to follow up the merits or demerits of various positions. For the most part, they may rely on Science to do the appropriate processing of information and summarizing for them. The examples $I$ have given may help the reader evaluate not only Onek's statements but the way Science analyzes news items. Caveat emptor. 


\title{
XVI. DEVELOPMENTS FEBRUARY-JULY 1994
}

\section{§1. "New" Evidence: The Myers Documents}

\author{
Extract from a letter dated 23 February 1994 \\ From John Dingell to NIH Director Harold Varmus \\ Available under the Freedom of Information Act
}

For over two years, the Subcommittee on Oversight and Investigations of the House Committee on Energy and Commerce has pursued an investigation of the Institut Pasteur/American HIV blood test patent dispute and related matters, including the research of Dr. Robert C. Gallo and his associates at the National Cancer Institute's (NCI) Laboratory of Tumor Cell Biology (LTCB). Newly discovered documents raise additional concerns about Dr. Gallo's candor and forthrightness on these matters. These and related concerns were not addressed, much less resolved, by any of the recent HHS investigations because the documents were withheld from the investigators....

As recently as mid-December 1993, the Subcommittee was still receiving documents that had been withheld for two years. Most recently, the Subcommittee learned of the existence of a cache of documents never provided to the Subcommittee, located in the NIH Freedom of Information Act (FOIA) office. (FOIA officials told Subcommittee staff that prior to January 1994, they were never informed of any of the Subcommittee's document requests.) Not only were these documents withheld from the Subcommittee, their existence was not disclosed to the NIH Office of Scientific Integrity (OSI), to the Office of Research Integrity (ORI), nor to the Office of the Inspector General (OIG) of the Department of Health and Human Services (HHS)....

The recently discovered documents are of great significance; they bear on the still-unresolved central issue of the entire case, i.e. the possible misappropriation of the Institut Pasteur (IP) virus, LAV. The documents principally comprise correspondence 
between Dr. Gerald Myers, a leading HIV geneticist, and a number of NIH scientists and senior scientific administrators, including Drs. Robert Gallo, Anthony Fauci, and Samuel Broder....

The subject of the correspondence is the genetic identity of LAV and "HTLV-IIIb"...

In brief, the Myers/NIH correspondence shows that: (a) as early as April 1987, Dr. Myers had concluded that Dr. Gallo's account of the origins of his prototype virus (i.e. the claim that IIIb was independent from LAV and the claim that IIIb was derived from blood pooled from several patients) constituted a "double fraud" and that this "fraud" had resulted in significant deleterious effects on progress in HIV research; (b) by April 1989, Dr. Gallo himself had finally decided to "throw in the towel," and admit publicly that his virus was derived from the IP virus; and (c) Dr. Gallo reneged on his commitment to make this public acknowledgment. The implications of these developments should be assessed in the context of Dr. Gallo's conduct and statements concerning the identity of the viruses over the years, as well as Dr. Gallo's failure to disclose this highly relevant information to OSI.

The contents of the Myers/NIH correspondence are summarized in a Subcommittee staff memorandum attached to this letter. The substance of the "Myers" documents (and their greatly belated submission to the Subcommittee, not to mention the fact that the documents were never provided to OSI, ORI, or the HHS OIG) are matters of considerable concern. The contents of these documents, particularly in light of the conclusions of the Richards Committee and many members of Dr. Healy's irregular secret committee, raise renewed concerns about Dr. Gallo's veracity and forthrightness on these matters.

The Subcommittee is interested in hearing your views on this matter and what actions you plan to take. You may want to ask selected members of the Richards Committee, or other independent scientists, to review this new information and to advise. Given the importance of these issues, we request a response by Wednesday, March 9, 1994....

[Dingell's letter was cc-ed to Dan Schaefer, Ranking Republican Member of the Subcommittee; Philip Lee, Assistant Secretary of HHS; Harriet Rabb, General Counsel of HHS; June Gibbs Brown, HHS IG; and Fred Richards.]

My comments: The Subcommittee staff memorandum mentioned by Dingell in his letter to Varmus is dated 15 February 1994. It is 7-1/2 pages long, and contains extensive quotes from 
the primary sources, that is, letters from Myers and statements from Gallo, substantiating Dingell's summary statements in his letter to Varmus. Both Dingell's letter and the Subcommittee staff memorandum to Dingell are available under the Freedom of Information Act, together with other "Myers documents."

To give readers an idea of the context in which the Myers documents occurred, I quote one passage from a memorandum from Myers to Gallo available under the Freedom of Information Act. Most of this passage is also quoted by Dingell's staff in their memorandum to Dingell dated 15 February 1994.

Excerpt from a memorandum, from Gerald Myers to Gallo, 3 July 1989: I gave you some tree analyses for the IIIb and LAV sequences. We have exhaustively verified these results and I just don't think they are going to change from what is seen.... I don't like being the person to have to tell you this, but I'm happier that the information is in my hands than in the hands of someone else. Up ahead, you'll have reason to think that I have worked against you (I don't think that, but I could understand how you would reasonably think so); this is the strongest argument against your position and the Tribune has not learned of it or anything of that sort. I have held it for nearly a year now, hoping for some resolution within the tradition rather than within the press...

It has been my hope that you would not be placed into a "reactive" position but rather a position of taking the initiative. It has been my hunch that the Tribune series (assuming it is going to be published, which is always a strained assumption) ${ }^{1}$ would be deflated by a bold move on your part. I understand that you are not as free in this regard as you would ideally be and, I could be wrong in my hunch. Let me know your thoughts and how I can help. I do feel some obligation to the French and to the database along these lines, but those considerations do not impose a time constraint....

\section{The Latest from Fred Richards}

The release of the Myers documents by the Dingell Subcommittee had a very substantial effect on Fred Richards, and some effect

${ }^{1}$ In fact, Crewdson's first article came out in November 1989. 
on members of his panel. Science and Government Report reported this latest evolution, because they accepted to have an interview with Dan Greenberg. Crewdson subsequently informed readers of the Chicago Tribune (19 June 1994) where he quoted Fred Richards' statement from SGR, but Science, Nature, and the New York Times did not so inform their readers.

\section{Extract from Science and Government Report 15 May 1994}

\section{"Advisor in the Gallo Case Calls for Reopening of Probe"}

Like an underground fire that won't go out, resentment continues to seethe over the official exoneration of the renowned Robert C. Gallo from charges that he robbed French researchers of credit for identification of the AIDS virus.

Breaking a long silence, Frederic M. Richards ... told SGR in an interview on April 25 that two items of newly available evidence warrant a reopening of the investigation.

First, Richards cited sworn statements by a French researcher, Francoise Barre-Sinoussi, head of the Retrovirus Biology Unit at the Pasteur Institute....

The second item of evidence cited by Richards is a recently discovered cache of letters and memoranda in $\mathrm{NIH}$ files written by Gerald Myers, a researcher at the Los Alamos National Laboratory who served as Principal Investigator of the HIV Sequence Data Base, under a contract from NIH. Myers reported to NIH that his researches indicated that LAV, and not Gallo's HTLV-III, was the cause of AIDS. Myers subsequently stated that after his findings were brought to Gallo's attention, Gallo gave but then reneged on an assurance that he would publish a statement reflecting Myers' conclusion....

The "major purpose of this whole investigation," Richards said, "was to find out whether they stole the virus. The answer is, they stole the virus. But we didn't know that at the time these [investigative] reports came out."

Contacting three of Richards' colleagues on the misnomered "Richards Panel," SGR found all dissatisfied with the outcome of the Gallo case, but uncertain over what if anything should be done about it at this stage.... 
Neither Science nor the New York Times reported the evolution of Fred Richards or members of his panel. If you are surprised, come to the front of the class because you haven't been paying attention.

\section{§3. Revision of the Patent Agreement}

In February 1994, the Institut Pasteur pressed the Clinton administration, and the new NIH Director Harold Varmus, for an acknowledgment that the Americans (Gallo) had used the French virus for the HIV antibody blood test, and for a revision of the patent agreement. The communications from Pasteur's Director Maxime Schwartz to Varmus are available under the Freedom of Information Act. Partly under the threat of a renewed law suit by the Pasteur Institute, and partly under pressure from the HHS Inspector General's memorandum, a new agreement was reached, substantially increasing the share of royalties going to the Pasteur Institute. The new agreement was covered in the press, for instance:

"Varmus in Quick Reversal on Gallo Patent Dispute," Science and Government Report, 1 July 1994.

"U.S.-French Patent Dispute Heads for Showdown," Science, 265, 1 July 1994, p. 23.

"AIDS-BLOOD-TEST ROYALTIES-NIH-Pasteur: A Final Rapprochement?," Science, 265, 15 July 1994, p. 313.

"Key Patent on AIDS To Favor the French," New York Times, 12 July 1994.

"U.S., France settle AIDS virus dispute," Chicago Tribune, 12 July 1994, p. 1.

As late as 8 June 1994 Varmus had replied to Maxime Schwartz that "the acknowledgment of the role of the Institut Pasteur in isolating the AIDS-causing virus was very slow to occur, causing much frustrating litigation and other unproductive activity," but nevertheless Varmus was adamant that the previous agreement would not be modified. However, when the IG's Report came out a couple of days later on 10 June, Varmus changed his tune and the new agreement was reached. The abrupt change is noted both in the Chicago Tribune and the Science article, in complementary ways, which are instructive to understand how the higher-ups function: 
According to Crewdson: "Asked Monday whether the Inspector General's inquiry, details of which first were reported last month in the Tribune, had played any role in the reversal of the U.S. position on the royalty issue, Varmus appeared to hesitate before replying, "Very little." Sources said a more probable explanation for the shift was the lawsuit Pasteur was prepared to file had negotiations failed. The suit claims that HHS concealed evidence from, and made false representations to, the French that induced them to settle the case in 1987. In an impassioned letter to Varmus last month, Schwartz declared bluntly that 'a cover-up of the true facts was deliberately undertaken so that we would settle."

According to Science, 1 July 1994, p. 25: "Varmus finally replied to Schwartz on 8 June. In his 'considered judgment,' the NIH director wrote, the royalty arrangement should stand.... Then came the OIG's 10 June report. Two weeks later, Varmus wrote Schwartz a letter with a different tone..."

Subsequently, Varmus reinforced somewhat the role of the HHS Inspector General's Report on his own thinking, as reported in Science two weeks later:

According to Science, 15 July 1994, p. 313: "Varmus acknowledged, however, that a 10 June report of an official investigation into Gallo's lab by the HHS Inspector General, which was critical of Gallo (Science, 1 July, p. 23), "had some catalytic role in my own thinking."

At the same time, Varmus explicitly stated that no "deliberate misconduct by the government" was found, and his disclaimer about "culpability" or "wrongdoing" by the government or Gallo was reported in the press articles mentioned above. In any case, the choice by Varmus on 1 July to minimize the effect of the HHS Inspector General's Report on himself ("very little") raises a fundamental objection: When the higher-ups themselves do not take seriously into account the information which comes officially from their own organization, or mininize the importance of this information, then something is fundamentally cockeyed. But that's the way "the system works," as the saying goes. And Varmus is very much part of "the system."

The Inspector General's memorandum is mentioned only incidentally with a few words in the New York Times article, and no direct connection is made between the appearance of this memorandum and the change of mind by Varmus to reconsider 
the patent agreement. The New York Times provided no analysis of the IG's memorandum.

\section{\$4. Running Interference by Gallo's Attorney}

In $\mathrm{XV}, \S 4$, I have already given one example how to process information when I analyzed a significant false statement made by Gallo's attorney Onek in his letter to the HHS Inspector General (23 June 1994). I shall give below two more samples of juxtapositions which can be made to compare Onek's assertions with the record. Readers can obtain the whole Onek memorandum from Gallo directly at the LTCB. I urge readers to compare what Onek wrote with the ORI Offer of Proof and the HHS IG's Report, which contain documented factual assertions about the history of Gallo's behavior, as well as repeated lists of scientists willing to testify about Gallo's deviation from accepted standards. It is possible to make up similar juxtaposations with several other statements by Onek, a task which I leave as an exercise for the reader.

Running interference by the legal system. There is another issue here, transcending the question whether Onek's statements are compatible with documented reality. This is the issue of a scientist dealing with other scientists through the legal system. I object to Gallo interposing a lawyer between himself and the scientific community. As a scientist, Gallo is directly responsible to the scientific community, which is entitled to hold him directly accountable for what Onek writes on his behalf.

\section{EXAMPLE 1}

Joseph Onek writing for Gallo, in his letter to the HHS Inspector General, 23 June 1994, p. 6: The [Inspector General's] memorandum neglects to mention that the Pasteur, by its own admission, has no legal rights to more blood test patent royalties. That is why the Pasteur does not bring its case to court. Instead the Pasteur makes an "equitable" claim for more royalties. But Pasteur officials let French citizens become infected with AIDS in order to promote Pasteur's commercial position. What possible equitable claims can such officials have? And how can American officials support such claims? 
In fact, American officials have supported the claims. The patent agreements were revised at about the same time Onek wrote to the Inspector General. Furthermore, the Institut Pasteur was continuously threatening litigation. Readers can compare Onek's statement with the following:

- The HHS Inspector General's Report, p. 27, which we have already quoted in XVI, §4: "Gallo did not disclose to the United States Patent Office the Pasteur scientists' 'prior art,"' i.e., their extensive work with the virus, LAV, and the existence and use of the LAV antibody blood test. Further, Gallo did not disclose to the patent office any of the LTCB's own experimental work with LAV.

The relevance of the IP's [Institut Pasteur] work to that of Gallo et al. was affirmed by the PTO [Patent Office] examiner, when she became aware of it. The examiner advised the OIG [Office of the Inspector General] that, had she been aware of the IP prior art at the time she examined the blood test application of Gallo, she would have suspended prosecution of the Gallo application and declared an interference between the two applicants."

- The letter from NIH Director Harold Varmus to Maxime Schwarz, Directeur of Institut Pasteur, 8 June 1994. In this letter Varmus stated: "The acknowledgment of the role of the Institut Pasteur in isolating the AIDS-causing virus was very slow to occur."

- The statement by Varmus when he announced the new patent agreement, 11 July 1994, that HHS and NIH "officially acknowledge" that Gallo's lab "used a virus provided to them by Institut Pasteur to invent the American HIV test kit."

- The report in the Chicago Tribune (12 July 1994, "U.S., France settle AIDS virus dispute," p. 1) that "Pasteur was prepared to file had negotiations failed. The suit claims that HHS concealed evidence from, and made false representations to, the French that induced them to settle the case in 1987."

As for Onek's allusion to the French officials who let French citizens be infected with AIDS, it is correct that French officials in the medical bureaucracy allowed an existing blood supply contaminated with HIV to be exhausted before applying the available blood test. Since Onek brought up the issue, it is relevant to recall here that these French officials were condemned to jail terms.

On the other hand, Gallo himself refused to communicate some scientific information to certain colleagues at NIH. This information concerned the cell lines in which he was growing HIV. For this we come to our second example. 


\section{EXAMPLE 2}

After I circulated Suzanne Hadley's critique of the Nicholas WadeNew York Times article representing Gallo as a martyred saint, Onek wrote a memorandum on Suzanne Hadley's critique, and he wrote me a letter dated 17 June 1994, stating: "As the attached memorandum demonstrates, that critique is filled with errors and distortions. I trust you will now circulate my memo to your correspondents." I did circulate Onek's memorandum, but I also pointed to possible comparisons with the documented record. For example, Onek made the following statement:

Joseph Onek, writing for Gallo, in his memorandum concerning Suzanne Hadley, p. 8: "No effort was made by the LTCB to deny others the use of the H9 clone (the most successful of the cloned cell lines of HUT-78) or to hide the origins of the parental line. Records indicate that the LTCB made $\mathrm{H} 9$ available to at least 45 laboratories in 17 countries in 1984 alone. Dr. Popovic reported the HLA pattern of the H9 cell line clone in Lancet in 1985. Thus scientists throughout the world had the opportunity to determine for themselves the relationship of H9 to one or another HUT78. This includes Drs. Bunn and Gazdar, the co-developers of the HUT-78 cell line, who were the recipients of H9 in 1984."

Readers can compare Onek's assertion with the record, as documented in the ORI Offer of Proof. There, from pages 49 to 71 one sees continuously documented how Gallo obscured the cell line, refused to communicate it to some colleagues at NIH, and how he was ordered to do so by higher-ups at NIH. Several scientists are listed as willing to testify to Gallo's transgression of scientific standards, for instance, Martin, Schaffer, Curran, Richards, Tramont, Goldberger, Rall, Raub, Morgan, and McGinnis. I recall here a few of these references:

\section{From the ORI Offer of Proof}

p. 49. Meanwhile Dr. Popovic renamed the parental cell line, changing the name from "HUT-78" to "HT."... Dr. Gallo systematically misrepresented the origins of the HT cell line 
so that his fellow-scientists could not discern HT was really HUT-78....

p. 53. Numerous ORI witnesses will testify that it was a serious deviation from accepted practices for Dr. Gallo not to identify HT/H9 as a derivative of HUT-78, or at least to disclose this possibility, both in the initial Science paper describing $\mathrm{HT}$ and $\mathrm{H} 9$ and in subsequent communications...Among the witnesses ... are Dr. Schaffer, Dr. Curran, Dr. Richards, and Dr. Tramont.

p. 57. The evidence will show that despite clear standards in the scientific community that reagents should be freely distributed to responsible scientists, Dr. Gallo (1) refused outright to provide the uninfected $\mathrm{H} 9$ cell line to some researchers; (2) delayed providing the cell line for substantial periods of time for some scientists, while other scientists were promptly provided the reagents; (3) imposed restrictive conditions on the cell line to virtually all to whom he supplied it, with particularly onerous conditions for scientists not in his favor;...

p. 61. Refusal/delay in providing reagents: Gallo's treatment of certain of his PHS colleagues was particularly outrageous.... Dr. Malcolm Martin, a laboratory chief at the National Institute On Allergy and Infectious Diseases, NIH, requested the uninfected cell line from Dr. Gallo. Exhibit H89.... Dr. Gallo refused Dr. Martin's request...Exhibit H102. Dr. Gallo also demanded to know what Dr. Martin intended to do with the uninfected cell line; Dr. Gallo explicitly stated that he did not want Dr. Martin to attempt to grow LAV in the cell line. Exhibit H-102 ... the agreement sent to Dr. Martin contained two additional particularly outrageous conditions: "Work with these reagents will not be published without prior approval by Dr. Gallo." and "Reagents will not be used in comparisons with other viruses."

p. 68. Dr. James Mason, formerly director of the CDC and former Assistant Secretary for Health, will testify that so egregious was Dr. Gallo's refusal to provide his reagents to CDC scientists who had requested them that he was forced to intercede on behalf of CDC researchers whose requests for the cell line and other reagents had not been honored by Dr. Gallo.... ORI witnesses will testify that Dr. Gallo informed CDC staff that LTCB intended to delay sharing of the reagents until Dr. Gallo felt he had accomplished his own work with the reagents. 
p. 69. Dr. Gallo's conduct was so antithetical to the mission of PHS and standards within the scientific community that, at a June 18, 1984 NIH AIDS Executive Committee Meeting, Dr. Wyngaarden specifically ordered Dr. Gallo to provide the uninfected cell line to Dr. Malcolm Martin and Dr. Walter Dowdle. Exhibits H-99, H-103.

pp. 70-71. In addition to the witnesses identified above, Drs. Goldberger, Rall, Raub, Morgan and McGinnis will testify to the accepted norms of scientific practice for identification of unique cell lines and their availability to the scientific community and Dr. Gallo's deviation therefrom.

In the memorandum about Hadley's critique, Onek also repeated what he wrote to the HHS Inspector General about the French blood test scandal. We have already dealt with this item in Example 1. Suzanne Hadley herself replied in a letter to Onek dated 14 July 1994: "No amount of fingerpointing at Luc Montagnier, the French Government, or anyone else will alter the nature and consequences of Bob's statements and actions, or make them any more praiseworthy. Yes, the French did have a blood test scandal. They at least dealt with it; they at least put their miscreants in jail...."

Suzanne Hadley concluded her letter to Onek with the statement: "The record is compelling. The truth-in its entirety, and at long last-will come out. It really will."

\section{\$5. Failures of Scientific Responsibilities}

The entire Gallo affair provides evidence of the way the scientific community is unable to police itself.

- The NAS and IOM have systematically evaded responsibilities from beginning to end, culminating with the "convocation" on misconduct of 6-7 June 1994 (see my essay "Maintaining Standards"). I remind readers that Gallo was elected to the NAS in 1988.

- Strong forces in the government and in the scientific community obstructed the search for the truth in the Gallo affair. I list some items documenting obstructions following the nomination of the Richards Panel by the NAS and IOM at the request of HHSNIH: The "reining in" (dismissal) of Suzanne Hadley by NIH Director Bernadine Healy, thus derailing the investigations; the subsequent manipulation and mistreatment of the Richards Panel by NIH, especially Healy; the withholding of documents 
from the Richards Panel (e.g., the Myers analyses and the Roche analysis), from ORI, and from the Dingell Subcommittee; the panel's acceptance of this treatment without protesting publicly; the evasion of responsibility of the NAS and IOM toward the Richards Panel; the fact that we have to learn of the Richards conclusion from Science and Government Report, but do not get this information from NIH-HHS, the NAS, or Science (never mind Nature, which is a dead loss).

- In Spring 1994 Fred Richards concluded that "they stole the virus," but he said that "we didn't know that at the time these [investigative] reports came out." Actually, some scientists such as Don Francis had been saying that all along. One reason some other scientists did not know is that under Bernadine Healy, the Roche analysis was withheld by OSI from the Richards Panel at the time the OSI Report came out in 1992, and the Richards Panel did not investigate independently to find out what was being withheld from them. Also under Bernadine Healy, and continuing for months after she left, NIH stonewalled requests for documentation from the Dingell Subcommittee. Ultimately it was not the scientific community which uncovered the Myers documents, it was the staff of the Dingell Subcommittee; and we learned some of this information from Dan Greenberg and John Crewdson, not from Science or Nature.

- The Onek-Gallo replies to scientific governmental evaluations, and the aborting of the ORI and HHS Inspector General's investigations by the legal system, show how lawyers are pushing the scientific community to adopt legalistic thinking, which is on the way to replace the exercise of scientific responsibility. The main criterion for acceptable behavior is quickly becoming that if what one does is not demonstrably illegal (and, in particular, criminal intent cannot be proved), then it's OK. NIH Director Varmus and the Secretary of HHS have so far done nothing official about the reports of ORI and the HHS IG, and Gallo was still Chief of LTCB in Fall 1994.

- In the ORI Offer of Proof, one sees repeatedly that a couple of dozens of scientists were willing to testify about Gallo's multiple transgressions of scientific standards, including Don Francis, Montagnier, Barré-Sinoussi, Martin, Curran, Cabradilla, Goldberger, Rall, Morgan, Raub, Huth, Richards, and other members of the Richards Panel, Schaffer, Tramont, Woolf, McGrath, Hadley, etc. But we have to get the Offer of Proof individually under the Freedom of Information Act to get this information. We did not get this information from the NAS, from Science, or from official reports of the Richards Panel. Why should scientists cooper- 
ate with governmental investigating agencies if their efforts are ignored or disregarded by the higher-ups, in the government and in the science establishment?

- The documentation is massive, and some (many? most?) individual scientists may consider that they have other things to do besides processing the information contained in the documents arising from the case. On the other hand, the standard journals don't provide the information properly (Science, Nature, etc.).

- The abdication of responsibility by the higher-ups in the science establishment (NAS, IOM, NIH, HHS, and the scientific journals such as Science and Nature) make it very clear that individuals who attempt to maintain standards are isolated, or disregarded, or obstructed by the scientific establishment. This is the lesson derived from the Gallo case for those scientists who would be willing to detract from time possibly spent on research, to get engaged in a battle for standards. 


\section{THE DINGELL SUBCOMMITTEE STAFF REPORT}

\section{\$1. Obstruction and Withholding of Information by NIH}

The Dingell Subcommittee experienced considerable difficulties in obtaining information from NIH. These difficulties were mentioned by Dingell himself as quoted in the preceding section, and I learned of them via the usual sources of information, Greenberg's Science and Government Report, or Crewdson's articles in the Chicago Tribune, but not from Science or the New York Times, to mention only two of the mainstream press. I quote from the informative sources.

(a) According to Greenberg's Science and Government Report of 1 December 1992, Dingell accused NIH Director Healy of hampering the Gallo probe as follows:

In a nine-page-single-spaced letter dated November 26, Dingell accuses Healy and close associates of deliberately, perhaps illegally, thwarting his inquiry into NIH's dispute with the Pasteur Institute over patent rights to the blood test for the AIDS virus....

Stating that my "patience is near an end," Dingell declares in his letter to Healy that "there is a clear pattern of delay, obstructionism, and abuse in the NIH's actions in this matter that is intolerable, and strongly suggests that a cover up is under way."

... Dingell's letter to Healy presents a long inventory of difficulties that his Subcommittee staff has encountered in obtaining documents from NIH related to the patent controversy, which Dingell's Subcommittee is investigating as part of its long-running inquiry into how science polices its use of public funds.

In several instances, Dingell wrote, NIH denied the existence of documents but then turned around and supplied 
them when his staff insisted that they were in NIH files ... Dingell writes: "... The NIH apparently is still withholding documents."

(b) In his Chicago Tribune article of 6 December 1992, concluding a section entitled "Political Science," Crewdson wrote:

Recognizing belatedly that she [Suzanne Hadley] was expected not to expose the facts her investigation had turned up but to bury them, Hadley jumped ship. Although she is still on the NIH payroll, Dingell asked several months ago that she be assigned to his staff....

She has become profoundly disillusioned with the agency for which she once cared deeply. "There never was an iota of a chance," Hadley says, referring to what she calls the original cover-up, "that NIH would do the honest thing. Before anything had even happened the die was cast, the decision was made. After that it was simply a matter of crafting a litigation strategy."

... But Hadley's background-during the years at NIH she never received a rating lower than "outstanding"-has given Dingell's current crusade an unusual degree of credibility.

Hadley and her new colleagues now have nearly all the pieces of the puzzle in place, and sources there say they believe they know what happened in Gallo's lab. When the subcommittee publishes its findings, the historical record perhaps will be complete at last. It will be too bad for scientists that the truth came not from science but from Congress....

(c) We have seen in XVI, §2, how Dingell's staff finally extracted the Myers documents from the files of NIH in December 1993, after these documents were withheld from Dingell over the years.

\section{The Dingell Subcommittee Staff Report}

As of January 1995, the Dingell Subcommittee on Oversight and Investigation was no more, because of the Republican majority victory in November 1994. However, the Subcommittee staff had prepared a report which is mostly due to the work of Suzanne Hadley, and which became available during January 1995. This report is 267 pages long. It is accompanied by an Executive Summary, 65 pages long. 
Some scientists had written to Dingell in 1994 to urge the Subcommittee to issue the report on the Gallo case. ${ }^{1}$ It is unfortunate that the political circumstances have prevented this report from being available from the Government Printing Office, especially since there were Republicans on the Subcommittee, which on this issue appeared bipartisan. Individual scientists and the media now have the responsibility for the distribution of the Subcommittee Staff Report, which contains extensive documentation. Much of this documentation has not been publicly available before, partly because NIH covered it up. The full text can be accessed via the World Wide Web at the following URL:

http://nyx10.cs.du.edu:8001/ wstewart/

1 For example:

- 23 January 1994, from Elliott Lieb to Dingell: "I am writing to urge, in the strongest possible terms, that your committee issue a full report on the Gallo case. It is clear that this case and its importance did not die with the Appeals Board ruling. It is also clear that the public, and especially the scientific community needs to know everything that your committee found despite the obstructions laced in your way. We need this information if we are to maintain high ethical levels in science and in the administration of science." (Elliott Lieb is Jones Professor of Mathematical Physics at Princeton, and is a Member of the NAS.)

- 4 February 1994, from John Edsall to Dingell: "As a biochemist who is deeply concerned with maintenance of standards of integrity in scientific work, I have followed the controversy over the discovery and identification of the virus of AIDS, with particular reference to the role of Dr. Robert Gallo... I believe that the standards of ethical conduct for scientists are, and should be, more demanding than the purely legal rules. They must be so, if the public is to retain its confidence in the scientific community. In fact, looking at the history of the Gallo investigation. I see a pattern of evasion, and suppression of information, at several points along the line.... It appears, however, that the attempt to clear Dr. Gallo of all legal charges against him is on the verge of complete success. If you have strong evidence that could lead to a different conclusion, would not this be the time to make it public, in the interest of truth and honesty...? (John Edsall is Professor of Biochemistry Emeritus at Harvard, and is a member of the NAS.)

- 7 February 1994, from Charles Park to Dingell: "You are to be congratulated for your continued pursuit of the truth in the Gallo case. What you have done and hopefully continue to do is very important and is much appreciated by the scientific community. I understand that your Subcommittee on Oversight and Investigation has collected information on the Gallo case that has not previously been made public. I hope the Committee will make a full disclosure of this material." (Charles Park (M.D.) is Professor Emeritus of Physiology, and is a member of the NAS.) 
It remains for individuals, and especially scientists, to speak out and act. I personally distributed copies of the Staff Report to a cc list of over 100 persons throughout the United States, and in addition, I sent a copy for duplication and distribution to the Council of the National Academy of Sciences.

One member of the Academy, from whom I had never heard previously, wrote me on 26 January 1995 concerning the Staff Report:

... I have read through all 336 pages of the depressing document and I strongly agree that NIH must do something. As a lawyer would say, the appropriate remedy should include, but not be limited to, the following:

1) The Director, NIH should issue a public apology to the IP on behalf of present and past officials who engineered this appalling coverup, and on behalf of the scientific staff of NIH.

2) All rights under the present HIV test patent should be assigned to the IP and Drs. Barré-Sinoussi, Chermann, and Montagnier.

3) The Staff report of the Dingell Committee should be made a part of the NIH Annual Report for 1995.

4) All royalties received by the U.S. government during the entire term of the patent should be remitted with interest to the Institut Pasteur.

5) All payments to Drs. Gallo, Popovic, and Sarang should be retrieved and returned to the IP.

Note that, apart from repayment of money, there is no mention of punitive actions against anyone: this is not a legal matter, it concerns the good name of NIH.

I realize that Dr. Varmus would likely be fired in short order if he attempted to do any of this, but nothing would do more to create an issue that scientists, especially intramural NIH scientists, could speak out about than that! For him it would be a wonderful opportunity to become known as the first NIH Director who actually stood for something besides the efficient absorption of federal funds.

I welcome suggestions. Enclosed is a check to help with your distribution costs for all those reports. I should have sent it long ago when you were fighting the Huntington case, but better late than never. 
The letter was signed by William A. Hagins, Laboratory of Chemical Physics, National Institute of Diabetes and Digestive and Kidney Diseases.

The Subcommittee Staff Report confirmed the findings of the Inspector General's Memorandum and the ORI Offer of Proof, as far as they went.

The availability of the Subcommittee Staff Report shows once more the extent to which the main scientific press and the mainstream press have not provided proper, documented information to the scientific community and to the public at large, Greenberg and Crewdson excepted. On the other hand, it provides one more opportunity to learn or acknowledge the facts, and to speak out. I shall quote extensively from the Staff Report. I begin with extensive quotes from the introduction to the Executive Summary.

\section{Staff Report \\ Subcommittee on Oversight and Investigation Committee on Energy and Commerce U.S. House of Representatives}

\section{Executive Summary}

\section{INTRODUCTION}

\section{A. The Subcommittee's Focus on the Institutional Response}

Encouraged by prominent scientists, the Subcommittee on Oversight and Investigations in 1987 began a review of the institutional response to cases of alleged or suspected scientific misconduct by scientists involved in federally supported research. At that time, the problem was readily discernible. When situations of possible scientific misconduct arose, the institution's response generally was to walk the whistleblower out the door, sweep the problems under the rug, and to protect, at all costs, the reputations of the senior scientists. As one scientist explained, "It was as if they had their own fiefdoms whereby they set their own rules."

In April 1988, the Subcommittee held what it expected to be its first and only hearing on the problems associated with how the 
institutions were responding to instances of scientific misconduct. What the Subcommittee did not recognize at the time was that rather than pointing out a problem that the community would rally around in an effort to correct, it was, in fact, exposing a not very well-kept secret that the scientific community was not prepared to deal with.

To those who were attempting to expose these problems, the hearing was a breath of fresh air. In the 24 hours after that first public hearing, the Subcommittee received reports of no fewer than 18 new cases of alleged scientific fraud. To those who wanted to maintain the status quo, the Subcommittee became a threat; numerous attempts were made to thwart the Subcommittee's efforts and limit Congressional oversight of Federally funded scientific research.

Given the debate, the Subcommittee felt it was important to go into the issue in further detail, and much as it did with defense contractors, generic drug manufacturers, and the nuclear power industry, the Subcommittee decided to select a case study to determine, in detail, how institutions respond to allegations of scientific misconduct and whether the system, in fact, works.

The case study selected for review was the so-called "Baltimore" case. The primary reasons the Subcommittee focused on this case were that (a) two institutions had already had-and botched-an opportunity to properly investigate the matter and (b) the whistleblower had been effectively driven out of science for her efforts in bringing the facts to light. The further the Subcommittee pursued the case, the more the community rallied around the defense....

Even as the Subcommittee began to see some progress at research institutions, it was evident that effort had been geared toward research institutions outside the Federal government. At the time, over a billion dollars was being spent at the National Institutes of Health (NIH) on intramural research. Consequently, it was important to determine if the same unwillingness to deal effectively with cases of potential misconduct observed in nonFederal institutions also existed within the Federal government's own research community. As a result, the staff was directed to conduct a case study involving allegations of misconduct in an intramural research program.

\section{B. HHS/NIH's Sorry History of Misconduct Investigations}

At this time, the Subcommittee was investigating the Laboratory of Tumor Cell Biology (LTCB) within the National Cancer Institute (NCI) at NIH, due to allegations of kickbacks and diversion of 
Federal funds by two prominent scientists within that laboratory. Ultimately, both investigations resulted in felony convictions. As a result, in 1989, when allegations of scientific misconduct resurfaced against the chief of that laboratory, allegations which had first been raised in 1985-86, the Subcommittee was in a good position to use the LTCB as its intramural case study.

In contrast to the situation at extramural research institutions, there has been little or no progress at the Department of Health and Human Services (HHS) or NIH in their response to cases of possible scientific misconduct in the intramural laboratories. In fact, the situation at HHS/NIH resembles the situation at extramural institutions more than ten years ago....

The only real attempt at NIH to vigorously examine the facts of this case occurred when Dr. William Raub was the Acting Director of NIH. Dr. Raub insisted on the appointment of an independent panel, nominated by the National Academy of Sciences (NAS), to review HIH's handling of the case, to ensure an adequate response.

Initially, the NIH assigned its new Office of Scientific Integrity (OSI), assisted by an outside panel of experts, to conduct a formal inquiry and investigation. While this beginning was very positive, it shortly unraveled. In 1991, a new NIH Director was selected: Dr. Bernadine Healy. By the time of her appointment, the OSI investigation had been completed and a draft report had been prepared.... Concerning Dr. Gallo, the entire panel and OSI severely criticized Dr. Gallo and they strongly questioned his fitness to continue to serve as a laboratory chief at NIH. But then, through a series of events described later in this report, Dr. Healy effectively demolished OSI, greatly limited the supposedly independent review of the NAS Committee, and eventually attempted an endrun of its findings. In short, Dr. Healy did everything she could to protect her superstar, senior scientist.

In 1993, the NIH directorship changed again with the selection of Dr. Harold Varmus as Director of the NIH. The atmosphere of overt protectionism of Dr. Gallo was ended. However, although the HHS Office of Inspector General (OIG), the United States Attorney, and the Subcommittee had by this time amassed a substantial body of evidence demonstrating probable misconduct, Dr. Varmus, who was advised throughout by HHS General Counsel Harriet Rabb, refused to forward that evidence to a Surgeon General's Board of Inquiry, the duly authorized disciplinary body for the members of the HHS Commissioned Corps. Dr. Gallo is a Captain in the Corps.

In addition, despite strenuous pressure from attorneys and top 
officials of the Institut Pasteur (IP), Dr. Varmus refused to even consider a possible reallocation of royalties from the HIV blood test patent until he was confronted with a serous threat of an imminent lawsuit. Even when he finally agreed to a reallocation of the royalties, Dr. Varmus (with HHS' blessing) merely negotiated an increase in the IP share of the royalties, based on a disingenuous explanation of accounting anomalies, rather than the proven fact that the LTCB scientists, contravening a formal transfer agreement, used an IP AIDS virus isolate to make their blood test.

[Details of this transfer agreement are given on p. 24, as follows.]

The IP virus received at the LTCB in September 1983 was accompanied by a transfer agreement that stipulated the virus would "... not be used for any industrial purpose without the prior written consent of the director of the Pasteur Institute."

The transfer agreement further bound the recipient, "... not to disseminate the virus in any form (to companies or other scientists) without the prior written authorization of the Director of the Pasteur Institute."

Dr. Mikulas Popovic, a top LTCB scientist, signed the transfer agreement on September 23, 1983, affirming, in addition to the above, that the IP virus, “... will be used by the recipient himself, exclusively, and only for the following research purposes...: (a) biological; (b) immunological and (c) nucleic acid studies."

\section{Summary of the Subcommittee's Findings}

The popular view of the so-called "Gallo case" is that it is about whether Gallo et al. "stole" or misappropriated the IP virus. While this is indeed the central, original issue relative to the LTCB scientists, the case as it bears on the institutional response subsumes other vital issues, including how political and international reputational imperatives at HHS assumed preeminence over scientific integrity, and how defending the claims of the LTCB scientists came to be perceived as tantamount to defending the United States Government itself.

Major issues relating to the institutional response include the following: (1) the validity of HHS' claims to the United States Patent and Trademark Office (PTO), in applying for a patent on the LTCB HIV antibody blood test; (2) the integrity of HHS' response to the IP challenge in the mid 1980s, including the tacts and substance of legal briefs filed on behalf of Gallo et al; and (3) the integrity of HHS current response to the mounting body of evidence 
calling into question the actions and statements of both NCI scientists and HHS officials/attorneys.

1. Did Gallo et al. Misappropriate the IP Virus? [The Executive Summary then goes into some concrete evidence, partly confirming the evidence already mentioned coming from the Offer of Proof and the HHS IG Memorandum, and partly some evidence which I had not been aware of.]

2. The Institutional Response: The manner and content of HHS' response to the challenge to Gallo et al. was set as early as April 23,1984 , the day of the HHS press conference. Although a few crumbs were thrown to the IP scientists, the glory was all for Gallo et al. and the United States Government. Numerous unsubstantiable claims were made at the press conference by "our eminent Dr. Gallo," as HHS Secretary Margaret Heckler repeatedly described him. Secretary Heckler also elaborated at some length how the LTCB scientists' "discoveries" proved the administration's commitment to AIDS/HIV research.

Just minutes before the press conference, HHS submitted applications for U.S. patents on an HIV antibody blood test and a method of producing the virus. These patent applications contained the seeds of the French/American dispute; they contained fundamental assertions that could not be substantiated. Chief among these was the assertion that

“... we are the original, first and joint inventors ... of the subject matter which is claimed and for which a patent is sought..."

The real inventors of the HIV blood test were the IP scientists, who had developed and begun to use their blood test the previous Summer (1983)....

Dr. Gallo and his colleagues did not disclose to PTO their knowledge and use of the IP blood test, nor did they disclose the IP scientists' considerable body of scientific work on their virus and blood test....

The HHS response to the IP challenge, which at this time was informal, was immediate and reflexive. The response was to defend-at all costs and irrespective of the evidence-the claims of Gallo et al. The Subcommittee investigation showed that HHS officials and attorneys conducted a parody of an investigation; they did not seek the truth, but rather sought to create an official record to support the claims of Gallo et al. HHS officials accepted 
uncritically everything they were told by Dr. Gallo and his colleagues, incorporating the LTCB scientists' information unqualifiedly and without confirmation into official reports of the Department. When these officials encountered hard evidence that contradicted the NCI/HHS claims, the evidence was ignored, discarded, and/or suppressed.

DOJ attorneys, in turn, took the "facts" they were given by $\mathrm{NCI} / \mathrm{HHS}$ and incorporated them, often nearly verbatim, into U.S. Government pleadings in the Claims Court and before the PTO. At the same time, HHS and DOJ sought by every means at their disposal to thwart IP's discovery of evidence that would reveal the truth about the LTCB claims. According to attorneys' notes and participants' accounts, despite top HHS officials' awareness that many of the claims of Gallo et al. were, at best, highly questionable and without substantiation, HHS determined to "play out" the U.S. defense as long as possible, and "roll over" only when defeat became inevitable.

The HHS agency-level cover-up started early. In August 1985, HHS charged NCI to "investigate" the claims of Gallo et al. The investigation was conducted by a single individual-Dr. Peter Fischinger-one of Dr. Gallo's superiors who even before he started his inquiry, pronounced the LTCB claims solid and entirely valid. Dr. Fischinger's investigation resulted in the so-called "Fischinger Report," which became the central substantive document on which the HHS/DOJ attorneys relied, in their defense of Gallo et al.

The manner in which Dr. Fischinger went about his task makes clear how perverse was the entire effort, and how distorted an account the Fischinger report provided regarding the so-called facts of the case. At the outset, Dr. Fischinger posed a series of questions to Dr. Gallo, questions that focused on demonstrably irrelevant non-issues, most notably the alleged "other isolates" of Gallo et al. Based solely on the responses of Gallo et al., Dr. Fischinger hurriedly wrote his report, which the Subcommittee investigation found to contain numerous incorrect, misleading claims (see below). Dr. Fischinger took the remarkable step of requiring Dr. Gallo to certify in writing that all the information contained in the report was correct and supported by data.

Only after completing his report did Dr. Fischinger write a super-confidential memorandum to Dr. Gallo, in which he (Fischinger) required Gallo to address "three major areas of oversight," one of which concerned the central issue in the entire dispute, i.e., the question of possible misappropriation of the IP virus. Regarding this issue, Dr Fischinger asked for a 
“... written statement ... that LAV was never used in any connection in ... the isolation of the HTLV-IIIb line."

Dr. Popovic's response to Dr. Fischinger's request concerning this major area of oversight was a nonresponse, a transparent evasion of Dr. Fischinger's request (see below, p. 47). Even Dr. Fischinger should have recognized something was being withheld from him, something was amiss. But Dr. Fischinger, so far as is known, did nothing. He permitted his report to stand, a report containing the blanket assertion that,

"There is no evidence that material from any outside laboratory including the French was used in generating the HTLV-IIIb virus..."

Based on the LTCB evasions and misrepresentations, HHS rejected IP's informal challenge. The matter soon thereafter moved into formal legal proceedings.

Yet at the very moment HHS was dispatching a September 6, 1985 rejection of the IP demands, HHS officials were confronted with damning new evidence that strongly challenged the claims of Gallo et al. On September 5, HHS officials traveled to the NIH where they were told by laboratory chief Dr. Malcolm Martin about experiments performed in his laboratory that showed the IP and LTCB viruses were generically identical, with the LTCB virus descended from the IP virus, and not the reverse. The following day, the same HHS officials travelled to the HHS Centers for Disease Control (CDC) where they learned that the IP scientists discovered HIV and made a blood test fully the equal of the LTCB test, long before Gallo et al. But these dramatic revelations did not in any respect alter HHS' course. In fact, HHS' only action was to ask Dr. Gallo to provide a further response. Meanwhile, HHS officials "deep-sixed" the extensive documentation they had been given to substantiate the Martin and CDC conclusions (see below, p. 47). Some of this evidence was withheld from the Subcommittee until late 1993.

With their claims rejected, in the Fall of 1985, the IP attorneys filed a request at PTO for an "interference" with the Gallo et al. blood test patent (an interference is USPTO procedure for determining priority of invention between two or more parties claiming the same patentable invention). In addition, in December of 1985, the IP attorneys filed a suit for breach of contract in the U.S. Court of Claims. The trust of the interference request was that 
the IP scientists should have been awarded the U.S. patent on the HIV antibody blood test, because they both isolated the virus and invented the blood test long before Gallo et al. and because their patent application clearly predated that of Gallo et al....

The legal pleadings submitted by attorneys defending Gallo et al. were packed with false and misleading claims, hardly surprising, given their exclusive reliance on information provided by the LTCB/NCI. The attorneys argued, in the strongest terms, that the IP and LTCB blood test viruses were distinctly, genetically different, e.g.,

"The scientific evidence is clear that HTLV-III and LAV are not so similar that HTLV-III can be the progeny of LAV" (Defendant's Reply to Plaintiffs Memorandum in Opposition to Defendant's Motion to Dismiss the Complaint; p. 6)

... Concerning the inventorship of the HIV antibody blood test, HHS/DOJ attempted to argue that the Gallo et al. test was a different invention from that of the IP scientists....

In addition, concerning the failures of candor and the duty of disclosure, the HHS/DOJ attorneys argued this:

"Nothing material or relevant was withheld from the examiner" (Opposition of Gallo et al. to the Motion for Judgment of Montagnier et al., p. A20).

The Subcommittee investigation showed that the HHS/DOJ legal arguments could not be substantiated. The HHS attorneys themselves recognized that they were on very thin ice. In closed door discussion with their counterparts at DOJ, the HHS attorneys described their principal arguments as a "weak thread to rely on" and "a two-edged sword."

The already-fragile HHS/DOJ arguments were further jeopardized in the Spring and Summer of 1986, first with the public revelation of electron micrographs of the IP virus, published by Gallo et al. as "HTLV-III," showing the virus productively growing in permanent cell lines. (This, of course, was the virus that Dr. Gallo had previously and repeatedly asserted did not grow.) Then, during the Summer of 1986, PTO-having finally comprehended how badly it had been misled-began to invoke the IP work as prior art to Gallo et al, threatening to throw numerous pending Gallo et al. applications into the ongoing blood test patent interference. The documented content of an "off the record" conversation between the PTO examiner and an attorney for Gallo et al. 
summed up the situation well:

“... several in the PTO [are] believing that HHS/NIH are withholding inform., i.e., that Montagnier may be the first inventor of most of these cases and that Gallo did indeed steal from him...."

Impelled by these developments, in the Fall of 1986, HHS increased its efforts to obtain a settlement of the French/American dispute. A settlement was signed, in March 1987, but the settlement barely managed to paper over the glaring unresolved issues, and it began to unravel almost before the ink on the settlement was dry.

HHS did its best to cover up the wrong-doing. Meanwhile, the failure of the entire scientific establishment to take any meaningful action left the disposition of scientific truth to bureaucrats and lawyers, with neither the expertise nor the will essential to the task. Because of the continuing HHS cover-up, it was not until the Subcommittee investigation that the true facts were known, and the breadth and depth of the cover-up was revealed. This report describes the facts, and how and why HHS went so badly wrong. [Emphasis added]

\section{CHALLENGES TO THE INVESTIGATION}

\section{A. Withholding/Altering/Destruction of Documents}

The challenges to the Subcommittee's investigation, and to the OSI and OIG investigations as well, were significant.... Documentary evidence was vital to the investigation; however, systematic withholding of documents was evident from the outset, on the part of both agencies and individuals. Key documents frequently were withheld for prolonged periods, in many cases, for years. Some critical documents known to exist were never officially produced. Among the most noteworthy such instances were the following:

- At least one incident of document destruction occurred during the pendency of the Subcommittee investigation, at the NIH Office of Scientific Integrity (OSI)....

- Documents in the possession of key participants in the HHS defense of Gallo et al. were claimed to be destroyed or lost. Former NCI Associate Director Dr. Peter Fischinger, for exam- 
ple, claimed that Hurricane Agnes flooded his home, with the consequent loss of all relevant documents in his possession.

- Dr. Lowell Harmison, formerly the Science Advisor to the HHS Assistant Secretary of Health, upon his retirement from HHS in late 1987 removed several boxes of documents from his office over a weekend with the assistance of the then-Deputy Assistant Secretary for Health. When HHS learned of Dr. Harmison's surreptitious document removal, it belatedly changed the locks on the door of his office and conducted a perfunctory "investigation" (an HHS attorney telephoned Harmison to ask him for an explanation). Harmison claimed that he disposed of most of the documents he removed from his office in the trash, and he asserted all his "official" correspondence should be available through the HHS Executive Secretariat. No such correspondence was ever produced for the Subcommittee. In fact, in stark contrast to Harmison's top-level, central role in the HHS defense of Gallo et al, only two documents bearing his signature were provided to the Subcommittee.

- A substantial number of highly significant documents were either withheld or heavily redacted before they were provided to OSI by Dr. Gallo and his colleagues. As a consequence, OSI was seriously misled concerning such significant matters as what experiments were performed with the IP virus, how the putative LTCB prototype HIV was "isolated," and when Dr. Gallo knew about these experiments.

- Several critical sets of data never were produced to the Subcommittee....

- A particularly egregious instance of document withholding at NIH came to light in late 1993, when Subcommittee staff learned from an outside source about the existence of a large cache of documents at the NIH FOIA office. These documents, never produced to OSI, the HHS Office of Inspector General, or the Subcommittee, included a set of documents (the "Myers documents") showing that in 1987, within days of the signing of the French/American settlement, leading American scientists had concluded that Dr. Gallo's claims for the origins of this "IIIb" virus amounted to a "double fraud."

The Myers documents also showed that in early 1989, faced with the evidence, Dr. Gallo was about to "throw in the towel" and admit publicly that the LTCB and IP prototype viruses are genetically identical, with the LTCB virus derived from the IP virus; At the last minute, Dr. Gallo reneged on his commitment to make a public acknowledgement of the viruses' identity, and a year later, 
when the OSI inquiry was underway, he asserted repeatedly that the viruses could be genetically independent, and even if they were identical, the "contamination" could have occurred at the IP, rather than at the LTCB....

\section{B. Interview Challenges}

Testimony posed at least as great a challenge as documentary evidence, partly because memories of some witnesses had eroded, due to the passage of time. At least as serious was the problem of willful forgetfulness and obstructionism, of which the following instances are exemplary:

- HHS attorneys manifested particularly severe memory deficits. During his October 8, 1992 interview by Subcommittee staff, HHS attorney Richard Riseberg emitted a remarkable number of "I don't know," "I don't recall," and "I can't help you there" responses concerning a number of critical events at which he personally was present....

- NCI and NIH Directors Drs. Vincent DeVita and James Wyngaarden each denied any significant responsibility for the defense of Gallo et al. Yet each said the other was importantly involved....

- Both Drs. Wyngaarden and DeVita, as well as every other key player at HHS, pointed to Lowell Harmison as the man in charge of the U.S. defense of Gallo et al., particularly during the critical early months of the French/American dispute. Attorney Richard Riseberg described Harmison as the "linchpin" of the HHS defense....

- Despite these characterizations, Dr. Harmison claimed little or no recollection of most major elements of the French/ American dispute, particularly his own role....

\section{THE LTCB HIV BLOOD TEST PATENT}

The April 23, 1984 filing of a United States patent application for the HIV antibody blood test of Gallo et al. was a defining event for HHS as well as the LTCB scientists. The commercialization of the IP virus in and of itself would violate the terms of the IP transfer agreement that accompanied the virus sample (see p. 24 for further details); the patent application further "upped the ante" dramatically for all concerned.... 


\section{B. What Gallo et al. Said in Their Patent Applications}

On April 23, 2984, when Dr. Gallo and his associate submitted applications for United States patents on their HIV blood test and a method for virus production, they affirmed, under penalty of criminal prosecution for making false statements, that they were,

“... the original, first and joint inventors ... of the subject matter which is claimed and for which a patent is sought...."

Gallo et al. affirmed, under penalty for making false statements, their duty,

"... to disclose information which is material to the examination of this application...."

\section{What Gallo et al. Withheld from PTO}

... The attorneys who prepared the April 1984 patent applications for Gallo et al. told Subcommittee staff that they instructed Gallo et al. about their duty of disclosure. Yet according to these attorneys, even they were not told by Gallo et al. about the IP prior art, nor were they told about the LTCB scientists' own work with the IP virus. Both the attorneys and the PTO examiner told Subcommittee staff that numerous aspects of the IP and LTCB work were material to the claims of Gallo et al. and should have been disclosed....

1. Knowledge of and Benefit from the IP Scientists' Work With Their Virus: The IP scientists were first to publish on the AIDS virus (Barre-Sinoussi et al., Science, May 1983)....

Gallo et al. did not disclose any of the IP publications to PTO, save for a single, misleading reference in one LTCB paper cited in one of the Gallo et al. patent applications, a reference that implied the LTCB and IP viruses were different. Neither did Gallo et al. disclose any of the IP scientists' papers, presented at meetings which Gallo and his colleagues attended. Consequently, the PTO examiner had to discover them on her own. The IP publications unquestionably were material to the Gallo et al. applications. In fact, when she belatedly became aware of the IP publications, the PTO examiner declared that both Barre-Sinoussi et al. and Montagnier et al. were "prior art" to the blood test CIPs of Gallo et al. For this reason, she repeatedly rejected every claim contained in these CIPs. 
The PTO examiner cited both sections 102[a] and 103 of 35 U.S.C. as the basis for her rulings. Concerning claims in the Gallo et al. blood test CIP applications, the examiner said the claims:

“... are rejected ... as anticipated by or, in the alternative,,.. as obvious over Barre-Sinoussi et al. ... or over the disclosures of Montagnier 9/1983..." (2/11/86 PTO Office Action, Gallo et al., SN\#635,610; p. 4).

“... are deemed to be drawn to subject matter which is the same as or substantially the same as that taught by BarreSinoussi et al. or Montagnier et al." (op. cit., p. 5).

“... are rejected under 35 U.S.C. 103 as being unpatentable over Barre-Sinoussi or Montagnier et al..." (4/4/86 PTO Office Action, Gallo et al., SN\# 643,715; p. 9).

The examiner further said that

“... the method taught by Barre-Sinoussi for the assay of LAV appear inherently to anticipate or render obvious the claimed methods drawn to assay of HTLV-III (op. cit. p. 9).

The PTO examiner's realization of the significance of the IP scientists' work came only after the Gallo et al. blood test patent had already been issued, too late for the IP work to be cited against that patent. By August 1986, once an "interference" had been declared between the Gallo patent and the IP blood test patent application, PTO was preparing to either suspend all the pending Gallo et al. CIPs or incorporate them into the interference. Either eventuality would have been significantly damaging to both HHS' patent program and HHS' position in the French/American dispute.

These developments occurred unbeknownst to the IP and its attorneys.... 


\section{COVER-UP AT HHS}

\section{A. Improvident Issuance of the Gallo et al. Patent}

In May 1985, the USPTO awarded a patent on the HIV antibody blood test to Dr. Gallo and his colleagues. The Gallo et al. patent was issued in record time, just thirteen months and one Office Action after it was submitted. At the time the Gallo et al. patent issued, the IP patent application, submitted over four months prior to the submission of the Gallo et al. patent application, had not been touched.... The differential handling of two applications for the same invention has never been satisfactorily explained, the consequences in disadvantaging the IP application are clear.

The IP application was passed among four different examiners; consequently, the application had never been "briefed," i.e., there was no PTO record of the IP claims. When the PTO examiner of the Gallo et al. application conducted an "interference search" just prior to issuing Gallo et al., she found no record of competing claims. According to the examiner, when she first saw the IP application, within two weeks of issuing Gallo et al., she recognized immediately that PTO had "screwed up" in issuing the Gallo et al. patent. The examiner told Subcommittee staff she recognized that the Gallo and Montagnier inventions were "directly related." The examiner also said that had she become aware of the IP application during her examination of Gallo et al., she would have suspended examination of Gallo et al. and "... would have thrown them into an interference."

But by the time the examiner saw the Montagnier et al. application, the Gallo et al. patent had already been issued. Consequently the burden of seeking an interference fell on the true inventors of the HIV antibody blood test, Montagnier et al.

[The Staff Report and the Executive Summary go on with meticulously documented statements about the history of the Gallo case. The above constitutes a sample of the ongoing text. I now jump to the concluding paragraphs, pp. 64-65.]

\section{CONCLUSIONS}

\section{B. The Subversion of Science and Public Service}

One of the most remarkable and regrettable aspects of the institutional response to the defense of Gallo et al. is how readily 
public service and science apparently were subverted into defending the indefensible.

To comprehend the significance of the subversion of public service in the cover-up, it is useful to review the Guidelines of the Ethics Committee of the Washington D.C. Bar Association concerning the roles of government attorneys. According to the guidelines,

"A government lawyer in a civil action or administrative proceeding has the responsibility to seek justice and to develop a full and fair record, and he should not use his position or the economic power of the government to harass parties or to bring about unjust settlements or results." (BC 7-14; p. 51)

These guidelines, although they focus on government attorneys, apply at least as well to the NCI/HHS science administrators who played such a crucial, "make-or-brake" role at the outset of the French/American dispute. The deliberately negligent "factfinding" conducted by these individuals, combined with their deliberate suppression of incriminating evidence, set the stage for everything that happened thereafter. But the attorneys bear significant responsibility as well, for they clearly did not seek diligently to "develop a full and fair record" of the facts about the claims of Gallo et al.

Neither did HHS/DOJ officials and attorneys, once the dispute was under way, deal responsibly with the accumulating evidence that there were serious problems in the U.S. Government's claims. Instead, they pushed on with their "litigation strategy," all the while adding deception to deception, consuming untold resources and squandering scientific and international good will. The fraud became self-perpetuating. Defending the indefensible became a reflex, until ultimately, the cover-up was so burdened with falsehoods that its collapse was inevitable. HHS officials and attorneys should have recognized early on that the falsehoods could not be indefinitely sustained. But HHS sought only to "defend the position." HHS did not see the truth. HHS did not honor the public trust.

The violence to principles of responsible, ethical science was just as profound. At a crucial point early in the LTCB's HIV research, international politics and the technocrats committed to those politics virtually took over that research, claiming the laboratory's putative accomplishments as accomplishments of the United States administration and by extension, the United States 
itself. Once done, the LTCB's interests became the Government's interests; defending the LTCB scientists' reputations and claimed accomplishments became necessary for defending the honor of the United States. The defense thus became a consuming effort for significant portions of the U.S. Government.

The result was a costly, prolonged defense of the indefensible in which the LTCB's "science" became an integral element of the U.S. Government's public relations/advocacy efforts. The consequences for HIV research were severely damaging, leading, in part, to a corpus of scientific papers polluted with systematic exaggerations and outright falsehoods of unprecedented proportions.

To comprehend how far from the ideal the defense of Gallo et al. led the scientific community, it is useful to note the words of two esteemed scientists, Drs. John Cairns and Paul Doty:

"... science is the pursuit of a truth that is external to our wishes. This truth is quite unlike the verdict of a court of law because it does not depend on advocacy" (John Cairns; Nature, 352, 1991, p. 101.)

"This challenge to readdress the fundamental tenets of acceptable behavior in science comes at a time when the traditions of the scientific enterprise are under new threats arising from new stresses and temptations.... As a result, the scientific community may already be experiencing a gradual departure from the traditional scientific standards.... In this way we risk sliding down toward the standards of some other professions where the validity of action is decided by whether one can get away with it. For science to drift toward such a course would be fatal-not only to itself and the inspiration which carries it forward, but to the public trust which is its provider." (Paul Doty; Nature, 352, 1991; p. 184).

There could be no better description of the disastrous consequences of the U.S. Government's defense of Gallo et al.

[I shall next reproduce extracts from the documentation itself, that is quotes from the main participant, Gallo, and some other people. These excerpts from the Executive Summary and Staff Report reflect some of the more notable of the numerous unsubstantiable or false claims, denials, and shifting stories relating to major issues considered by the Subcommittee's investigation. These ex- 
cerpts document meticulously how U.S. Government officials and attorneys adopted and promulgated, on behalf of the United States Government, unsubstantiable or false claims concerning certain putative accomplishments of Dr. Robert Gallo and his associates at the National Cancer Institute (NCI) Laboratory of Tumor Cell Biology (LTCB). S.L.]

\title{
EXTRACTS FROM THE STAFF REPORT
}

\section{SUBCOMIITTEE ON OVERSIGHT AND INVESTIGATIONS}

\author{
January 1995 \\ Selection by Serge Lang
}

\section{I(a). Claims that Gallo et al. Isolated HIV in 1982}

[Such claims were a central element of the U.S. Government's defense of the blood test patent of Gallo et al., because scientists at France's Institut Pasteur (IP) developed and applied for a patent on the HIV blood test months before Gallo et al. did so. The Staff Report documents, with quotes from the principals, that the claims of 1982 HIV isolates "were not true" (Executive Summary, p. 9). I reproduce some of these quotes.]

Gallo et al. in AIDS: Etiology, Diagnosis, Treatment and Prevention, 1985, p. 34: "The first HTLV-III [Gallo's name for HIV] isolates were obtained in this laboratory in November 1982, and HTLV-III was subsequently isolated from approximately 100 patients with AIDS or from healthy individuals at risk for AIDS." (Staff Report, p. 11)

Salahuddin, Gallo, et al., PNAS 82, 1985 pp. 5530-34: "Since the fall of 1982, independent isolates of HTLV-III have been obtained in this laboratory ... from 101 AIDS and ARC patients and healthy donors at risk for AIDS." (Staff Report, p. 12)

Opposition of Gallo et al. to the Motion of Montagnier et al. for Judgment, November 1986, Interference Proceeding of the U.S. Patent and Trademark Office (PTO), p. A8: "In late 1982-early 1983, [Gallo] obtained a number of viral isolates including HTLV-III." (Executive Summary, p. 54) 
Preliminary Statement of Gallo et al., PTO Interference, 1986: "The first written description of the invention [the Gallo et al. HIV blood test] was made on December 15, 1982." (Staff Report, p. 15.)

\section{I(b). Subsequent Shifts and Contradictions}

Gallo interview, Office of Scientific Integrity [OSI], 16 May 1990, transcript p. 110): “... you are asking me to defend something that I don't-I don't claim we had the cause of AIDS discovered in February 1983 or December 1982...." (Staff Report, p. 18)

Gallo remarks to the Chicago Tribune, published 19 November 1989: "The December ' 82 data is really marginal.... The data were equivocal. At the time they were not even real data.... The cells died. I can't make any claim for that. Some people would." (Staff Report, p. 19)

Gallo, OSI interview, 25 May 1990, transcript pp. 26-27: "I never made a claim in the literature for December ' 82 samples.... We didn't publish these claims in any publication. I am a scientist. I go by what I publish." (Staff Report, p. 20)

Gallo, OSI interview, 16 May 1990, transcript pp. 103-104: [Concerning the PNAS claims cited above] "For all of ' 82 ? ... Can I have the reference? I would like to see that in writing if I said that.... I don't believe I would have any reason to say that in PNAS. I mean, it doesn't sound like me." (Staff Report, p. 20)

Gallo in an interview with the Subcommittee Staff, Executive Summary p. 9): "No one believed we really had that many isolates.... No one believed we really meant that...."

\section{II(a). Claims that the IP Virus Did Not Grow at the LTCB}

[From the Executive Summary: "The LTCB scientists ... performed all of their seminal experiments ... with the IP virus, first under its own original name..., then under two different names...." (p. 4) "... the IP virus, under its own name, grew at least two-to-three months at the LTCB...." [beginning in the Fall of 1983] (p. 25).] 
Gallo to Ian Munro, editor of The Lancet, 6 March 1984: [Referring to the IP virus] "... their virus (viruses) have never been characterized nor transmitted permanently to recipient target cells...." (emphasis in original) (Staff Report, p. 37)

Popovic, Gallo et al., Science, 225, May 1994, p. 500: [LAV] “... has not yet been transmitted to a permanently growing cell line...." (Staff Report, p. 37)

Gallo to IP scientist Jean-Claude Chermann, 24 August 1984: "The sample of the virus you sent us the first time had, upon arrival no detectable virus..." (p. 1) and "... we did not grow LAV" (p. 3). (Staff Report, p. 38)

Gallo quoted in Science, 230, November 1985, p. 642: [Referring to the IP claim that "Gallo's group somehow grew the French isolate"] "Gallo indignantly disputes this allegation on several counts, including the fact that the ... amount of virus Montagnier sent would not have been sufficient to infect a cell line." (Staff Report, p. 38)

Gallo quoted in U.S. News and World Report, 13 January 1986: [Referring to speculation that "Gallo may have mistakenly contaminated his experiments with the French virus"] "That's the height of outrage," responds Gallo, who adds that "it was physically impossible" to grow the particles of virus sent by Montagnier. (Staff Report, p. 39)

Gallo to Dr. Peter Fischinger, Associate Director of NCI, 19 August 1985: [The first virus sample sent from the IP to the LTCB] "did not contain detectable virus." (Staff Report, p. 157)

Opposition by Gallo et al. to the Motion for Judgment of Montagnier et al., PTO interference, November 1986, p. A12: [Concerning the same virus sample] ."..no virus was found in this sample and it appears that virus initially present may have been killed in transit." (Executive Summary, p. 54)

\section{II(b). Shifts and Contradictions}

Gallo, OSI interview, 18 July 1990, transcript p. 65: [Concerning the first virus sample sent from the IP to the LTCB, the sample Dr. Gallo told NCI officials in 1985, "did not contain detect- 
able virus"] "... we knew we had something there and so we saved it." (Staff Report, p. 40)

Gallo, sworn declaration, PTO Interference, November 1986: [Concerning the second virus sample sent from the IP to the LTCB] "Dr. Popovic did succeed in temporarily transmitting LAV to a cell line called HUT-78 and one other T-cell line. However, both transmissions were only temporary in nature" (Executive Summary, p. 54)

Gallo, OSI interview, 8 April 1990, transcript p. 25: [Concerning the second set of virus samples sent from the IP to the LTCB, the samples whose growth Dr. Gallo asserted, in 1986, were "only temporary in nature"] "The growth was significant and continuous." (Staff Report, p. 28)

Gallo, OSI interview, 16 May 1990, transcript p. 87: “... there has been confusion in the response of what we did to LAV. In my response during the passionate period... 'Oh we never grew LAV' and of course we did grow LAV.” (Executive Summary, p. 26)

Gallo, OSI interview, 25 May 1990, transcript p. 13: "There is a point where I say I didn't grow LAV. And, of course, LAV was grown... Quite frankly, it wasn't so germane to me at the time and I was just anguished as to what was coming out of the newspaper. At that moment bombs were going off." (Executive Summary, p. 26)

\section{III(a). Obscuring the Origins of the First HIV-Permissive Cell Line}

[From the Staff Report: “Dr. Gallo's discovery of how to grow the AIDS virus in quantity occurred when Dr. Popovic lone of the LTCB's top HIV researchers] used another scientist's cell line [HUT781 ... to grow another scientist's virus isolate.... Gallo/Popovic gave the cell line a new name ' $\mathrm{HT} / \mathrm{H} 9$ ' ... giving no credit to the true originators, and thereby tacitly as well as explicitly claiming the 'discoveries' as the LTCB's own." (p. 53)]

Gallo remarks at the 5 April 1984 Beecham "Symposium on Infective Agents and Their Effects": "The breakthrough occurred for us when we learned how to transmit this [the AIDS virus] in a particular cell line developed in our lab ... a new line." (Staff Report, pp. 54-55) 
Fischinger Report, NCI's official response to the blood test patent dispute, certified by Dr. Gallo as true and supported by data, p. 10: [Referring to the original HUT-78 cell line] "... which is a relative of the HT cell line developed by Dr. Gallo...." (Staff Report, p. 166)

\section{III(b). Shifts}

Memorandum from Popovic to Gallo provided to NCI/HHS officials as part of the response to the blood test patent dispute, 6 September 1985: "The detailed characterization of the clone, H9, is being prepared for publication and its comparison with HUT-78 cells ... will soon be performed. In any case, why would anyone care?" [The phrase "why would anyone care?" was added to the memorandum by Gallo himself) (Staff Report, p. 57)

Gallo quoted in Science, 248, 1990: "I don't consider it so brilliant. In my mind, there is no credit for a cell line. If it happens by accident you have a cell line, so freaking what (p. 1500).... The fact is I never really thought it was important. And quite frankly, I still don't and I don't understand the people who do." (p. 1507) (Staff Report, p. 55)

\section{III(c) Comments by Other Scientists}

Dr. Albert Sabin, letter to Science, 249, 1990, p. 466: [Referring to the recently published finding that $H 9$ was identical to HUT-78] "This is not a trivial or irrelevant matter, as it was called by Gallo and Popovic, because the use of such uncontaminated, continuous lines of human T4 lymphocytes was crucial to the regular isolation of the new retrovirus from patients with AIDS and to the development of the antibody blood test by which it was possible to establish the etiological association of the virus discovered by Montagnier and his colleagues...." (Staff Report, p. 131)

Richards Panel statement, 19 February 1992: “... the so-called HTLV-III virus was thus established and introduced to the world with no reference to or discussion of two crucial facts ... the cell line utilized [HUT-78] was one that had been obtained from the Minna laboratory.... Although others could have obtained HUT-78 from the ATCC ... the essential identity of HUT-78 with H9 had been effectively obscured." (Staff Report, p. 55) 


\section{IV(a). Withholding/Restricting Use of Cell Lines and LTCB Reagents}

[Although Gallo made the cell line in which he was growing the virus available to some scientists, he either withheld it from others, or imposed restrictions. According to the Staff Report: "The selective withholding of the H9 cell line and the restrictions placed on its use compounded the harm from the failure of Gallo/Popovic to disclose the true origins of the cell line, i.e. HUT-78, at a time when ready availability of the first published cell line permissive for HIV might have significantly advanced AIDS/HIV research." (p. 131) “... Dr. Gallo went to considerable lengths to prevent scientists whom he knew had obtained the IP virus from using 'his' virus and 'his' cell line...to make their own comparisons" (Executive Summary, p. 43).]

Condition included in the standard materials transfer agreement prepared by the Gallo laboratory in Spring 1984: "Work performed will be on a collaborative basis with Dr. Gallo and his laboratory unless stated otherwise." (Staff Report, p. 127)

Condition included in a special LTCB transfer agreement imposed on Harvard University's Dr. James Mullins, 1984: "Use of $\mathrm{H} 9$ will be limited to my immediate laboratory for the specific purpose of transfection of CTV and HTLV-1 DNA. No other experiments will be carried out with this cell line without prior discussions with Dr. Gallo." (Staff Report, p. 131)

Condition included in a special LTCB transfer agreement imposed on Dr. William Haseltine, 1984: "Work performed will be on a collaborative basis with Dr. Gallo, Dr. Popovic, Dr. WongStaal, and their colleagues (to be specified by them) for the specific purpose of studying expression of HTLV--LTR linked genes in these cells. No other experiments should be initiated with these cells without prior discussion with the above named people." (Staff Report, p. 132)

Conditions included in special LTCB transfer agreements imposed on scientists at the Centers for Disease Control [CDC] and on NIH laboratory chief Dr. Malcolm Martin, 1984: "Work with HTLV-III will not be published without prior approval by Dr. Gallo" and "Reagents will not be used in comparisons with other viruses." (Staff Report, p. 132) 
Condition unique to the special LTCB transfer agreement imposed on scientists at the CDC, 1984: [Referring to LTCB cell lines] "They will only be used for seroepidemiologic studies and blood bank assays." (Staff Report, p. 132)

Gallo to Dr. Malcolm Martin, 22 June 1984: [Concerning the uninfected $\mathrm{H} 9$ cell line] "... I do not think it would be appropriate for you to put the French isolate in them. That is for them to do in collaboration with me and my co-workers and is ongoing." (Staff Report, p. 130)

\section{IV(b). Comments by Other Scientists}

Dr. Peter Fischinger, interview with Subcommittee staff: "I wouldn't do it, but Bob must answer for himself." (Staff Report, p. 136)

Dr. James Wyngaarden, former Director of NHH, interview with Subcommittee Staff: "Clearly inappropriate." (Staff Report, p. 136)

Dr. Vincent de Vita, former Director, NCI: "All restrictions are antiscience.... I think it's terrible." (Staff Report, p. 136)

Richards Panel Report, 19 February 1992, p. 3: "We consider failure to distribute uninfected $\mathrm{H} 9$ cells freely after publication of the article by Popovic et al. to be essentially immoral in view of the growing seriousness of the AIDS epidemic." (Staff Report, p. 131)

\section{V(a). Genetic Identity of the IP and LTCB Viruses}

[From the Executive Summary, p. 8: "In June of 1984, the LTCB scientists began a series of ... genetic comparisons of several HIV isolates, including LAV and 'IIIb'. The results showed that all the isolates were clearly different from each other, with one exception-the IP and LTCB prototype viruses-which were virtually identical ... there could be no question but that the IP virus was the original virus, i.e., that 'IIIb' came from LAV, and not the reverse.

“... Dr. Gallo ... devised a plan to make it appear that the French, in fact, had appropriated the LTCB virus.... When Dr. Montagnier vehemently objected and would not acknowledge the 'reverse con- 
tamination' scenario, given that the LTCB scientists had LAV long before the IP scientists received 'IIIb'), Dr. Gallo switched to the argument that the viruses, although very much alike, were genuinely independent."]

Fischinger Report, 27 August 1985: "There is no evidence that material from any outside laboratory including the French, was used in generating the HTLV-IIIb virus" (p. 3) and "It is clear that LAV was not used in generating the HTLV-IIIb virus strain advertently or inadvertently." (p. 8) (Staff Report, p. 166)

Gallo, reported in Science 230, 1985, p. 642: [Concerning the claim by the Institut Pasteur that Gallo's group somehow grew the French isolate] "Gallo indignantly disputes this allegation on several counts, including the fact that the viruses are not identical...." (Staff Report, p. 38)

Gallo, reported in the Wall Street Journal, 16 December 1985: [Concerning the allegation that Dr. Gallo misappropriated the French virus and presented it in his work, which later was patented] "Dr. Gallo refutes this, saying that the LAV and HTLV-III strains, although related, aren't identical.... Besides, the single LAV sample was too small to be of practical use, he argues...." (Staff Report, p. 203)

Defendant's Motion for Summary Judgment, 11 June 1986 , U.S. Court of Claims pp. 8-9: "Neither of these inventions [the Gallo et al. blood test and cell linel depended on or is derived from LAV isolates of the virus that is responsible for AIDS were available from many sources, and in fact, it was from these independently established isolates that HTLV-III was found." (Executive Summary, p. 55)

Memorandum in Opposition to Defendant's Motion for Summary Judgment, U.S. Court of Claims, 8 April 1986, p. 6: "The scientific evidence is clear that HTLV-III and LAV are not so similar that HTLV-III can be said to be the progeny of LAV." (Executive Summary, p. 55)

Brief for Appellee the United States, U.S. Court of Claims, 22 May 1986, p. 4: "Continuing research revealed that LAV and HTLV-III were two different isolates of the AIDS virus." (Executive Summary, p. 55) 
U.S. Government Attorneys in the U.S. Court of Claims, Oral Arguments, 22 May 1986: “... there are significant differences between the structure of HTLV-III[b] and LAV and you just can't say that HTLV-III is LAV by another name." (Staff Report, p. 213)

Brief for Appellee the United States, U.S. Court of Claims, 13 November 1986, pp. 4-5: “... Pasteur's statement that '[It] appears that Dr. Gallo and certain of his colleagues essentially took LAV, renamed it HTLV-III and the [sic] claimed and exploited it as their own' ... is an outrageous attempt to impugn the reputation of one of the world's foremost virologists and his coworkers." (Executive Summary, p. 56)

\section{V(b). Shifts and Contradictions}

Wong-Staal, Gallo et al., unpublished manuscript prepared after the above-mentioned experiments were performed, 1984: "LAV and HTLV-III [including 'IIIb"] are independent isolations of the same virus." (Staff Report, p. 117)

Ratner, Gallo, Wong-Stall et al., Nature, 313 (1985), pp. 636637: "HTLV-III[b], LAV, and ARV [another early HIV isolate] are variants of the same virus ... the closer similarity of the LAV DNA sequence to that of HTLV-III might be because the individuals from whom these isolates were derived acquired the virus at a similar time and place." (Staff Report, p. 166)

Gallo, draft statement, 17 April 1989, never published: "Can we conclude ... that HTLV-IIIb and LAVB BRU did indeed originate from the same individual? If that is indeed the case, it would only have resulted from a mix-up in my laboratory when the LAV from Luc Montagnier was temporarily growing along side the other isolates we had obtained. We certainly cannot rule this out, particularly since we and, I am told, many other investigators have often experienced the phenomenon of laboratory contamination of HIVs ... I do ... think it is necessary as a result of the data compiled in this book to acknowledge the distinct possibility that HTLV-IIIb and LAV BRU are the same isolate." (Staff Report, pp. 264-265) 
Gallo to Myers, 5 April 1990:2 "I have wanted to tell you for some time-that you were certainly right, and I should have listened to you ... as early as 1984, I told her [a reporter for Science] IIIb could be a contaminant of LAV. Because of everything else we did and because of other isolates and because of the help I gave Montagnier early on, I just could not believe anyone would really care." (Staff Report p. 267)

Gallo, "Opening Scientific Statement" to OSI, 8 April 1990: "With time and more sequences available the relative similarities of this pair (LAV and IIIb) remains unusual but not unique." (Staff Report p. 266)

Gallo, OSI Interview, 8 April 1990, transcript p. 34: "Shortly after our papers appeared in May ' 84 , three of these isolates ... were analyzed and shown to be distinct from ... each other by restriction endonuclease analyses. RF, MN, and JS [the three LTCB isolates] were also shown to be very different from LAV, but IIIb was similar to LAV." (Staff Report p. 102)

Gallo, OSI Interview, 11 April 1990, transcript p. 82: "I'm interested in a vaccine and in curing the disease. I'm interested in basic science and how the virus works. Do you think I'm going to get back there in the mud of whether IIIb and LAV came from this lab or the other lab when I have all kinds of other isolates and things are moving like a bullet? And I want to be worried about that, and did it happen in my lab, or their lab.... I mean, who bloody cares?" (Staff Report, p. 267)

Gallo, OSI Interview, 11 April 1990, transcript p. 71: "I have felt it is an irrelevant question, for the most part ... scientifically, ethically, medically and historically, because there are so many other isolates and if anybody had half as many in tissue culture within the next year I would be surprised, so I've never felt it to be an important question. It's only in this context of the questioning

${ }^{2}$ For statements by Gerald Myers, see below. 
that I'm getting here that it becomes important or for politics that have been played in newspapers...." (Staff Report, p. 267)

Gallo, OSI Interview, 11 April 1990, transcript p. 72: “... I would conclude that there can't be a conclusion today.... I don't think we can make any conclusive statement.... Also, please keep in mind that though I said if this possibility or probability exists ... I didn't tell you where it [contamination] happened with certainty also. I believe that question is open, no matter what information you may have...." (Staff Report, p. 266)

Gallo, in Virus Hunting, 1991, pp. 197-199: [Referring to experiments made in 1984] "About this time (June-July) Wong-Staal [Dr. Flossie Wong-Staal, another LTCB scientist] compared the genetic material of LAV with our isolates ... we learned that there was considerable variation in the viral genome when comparing one isolate to another.... Last and most unsettling, we discovered that one of our own HTLV-3B isolates was much closer to LAV than was typical of our other isolates.... Practically all were genetically different from one another. Yet LAV and our IIIb isolate(s) were distinctly close to each other." (Staff Report, p. 103)

Gallo to IP scientist Dr. Simon Wain-Hobson, 24 July 1991: [Referring to the 1984 experiments described immediately above] "Our conclusion was that we had a serious contamination problem...." (Staff Report, p. 101)

\section{V(c). Evaluations by Gerald Myers}

Dr. Gerald Myers to Dr. John LaMontagne et al., 8 April 1987, p. 4: “... it is the astonishing and unforeseen variation of the virus which exposes the fraud.... I suggest that we have paid for this deception in more than the usual ways. Scientific fraudulence always costs humanity ... but here we have been additionally misdirected with regard to the extent of variation of the virus, which we can ill afford during the dog days of an epidemic let alone during halcyon times." (Staff Report, p. 263)

Dr. Gerald Myers to Gallo, 20 September 1988, p. 1: "From our earliest tree analyses, it was patently evident that the LAV and IIIb viruses had to have had a recent common ancestor... By including all of the available gene sequences in a single analysis for the IIIbs, it is actually possible to define the branching order 
of the variants to a high degree of statistical precision. There is no doubt but that it shows the LAV source of the IIIb viruses: the NLA3 clone of the [LAV] BRU isolate is the oldest sequence; the published BRU follows it; the IIIbs follow thereafter..." (Staff Report, p. 264)

\section{Responsibility for False and Misleading Statements}

[From the Executive Summary, p. 54: "The U.S. Government pleadings, particularly those in the Claims Court and at PTO, contain numerous misleading claims. They also reflect numerous material omissions. The misinformation and material omissions are traceable directly to documents and statements prepared by Dr. Gallo and his LTCB colleagues, including numerous statements in the scientific literature, and documents and statements originating with Dr. Gallo's NCI and HHS superiors, including but not limited to Drs. Peter Fischinger and Lowell Harmison."]

Gallo, certification of accuracy and reliability of the scientific content of the "Fischinger Report," August 1985: "The enclosed attachment ... has been reviewed by me relative to the fidelity of specific information presented as well as the accuracy of its interpretation. These data are substantiated by entries in the notebooks, as well as by other records emanating from the Laboratory of Tumor and Cell Biology, NCI." (Staff Report, p. 161)

Gallo, interview with Subcommittee staff, July 1993: "I didn't read it [the Fischinger Report] as carefully as you might think." (Staff Report, p. 184)

Dr. Peter Fischinger, interview with Subcommittee staff, 1993: "My major point of discussion was Bob. No question about that. In terms of him trying to organize or find some of the data, some of the things that were going. I was listening to him as the point person....

I had a sense, at least from my perspective, there is laboratory data. Bob sort of swears that this is the way it is, and the laboratory data sort of generally support it, as opposed to no data. Then that's going to be his, sort of, ultimate responsibility. That was my feeling. So I would rely, myself, from a scientific point of view, in terms of what they did in the lab, he has the best knowl- 
edge, he should have the control of it.

My feeling was that Gallo has to go, and demonstrate this, and he has to defend what he has done, he has kind of sworn to the fact that he did what he did, and the fact that this is something that could stand in terms of his own laboratory's merit. And he sort of claims it even in terms of specifics, and has an argument that I could sort of believe in that is strong enough.

I said, 'Look, this is what you did. This is the summation of [what] you had said in your laboratory data to prove it. And let's take it from there." (Staff Report p. 160)

Gallo, OSI Interview, transcript pp. 99-109: “... I was asked by the United States Government to draw a lineage to the first time we detected this virus to show lineage of our work. You see what has happened as a scientist I am being put into a legal position, which I am not used to ... when I am asked to go back and draw lineage to our first experiments that have positive indications, that is what I did for the government.... But that wasn't for me to get scientific credit. Just suddenly I am in a legal thing. I am back to a morality ethics thing issue." (Staff Report, p. 17)

Gallo's attorney Joseph Onek, OSI interview, 3 August 1990, transcript p. 153: [Concerning Gallo's sworn declaration] "I should point out that, of course, this is a statement like any affidavit, but I am sure was prepared by lawyers, not by Bob...." (Staff Report, p. 210)

U.S. Government motion for extension of deadline, PTO interference, 30 June 1986, pp. 3-5: "The complex nature of the subject matter of this interference and the voluminous experimental work which led to the development of the patented invention [the Gallo et al HIV blood test] also require the personal participation of Dr. Robert C. Gallo.... Only Dr. Gallo is thoroughly familiar with the records relating to these developments ... the personal assistance of Dr. Gallo is of the utmost importance in pursuing these investigations." (Staff Report, p. 207)

From the Staff Report concerning an interview of a patent attorney with the staff, p. 19: "Another outside patent attorney said that for the most part, he had to rely on interviews with Dr. Gallo or his associates as a source of information. The attorney said he asked the LTCB scientists, 'Do you have data to support these claims?' and, 'Sometimes the data were provided; often they were not.' But, said this attorney, 'I never had any reason to 
doubt what I was told.' When confronted with significant pieces of data that contradict the claims of Gallo et al., this attorney responded, 'You're telling me things I know nothing about."'

U.S. Government attorney, interview with Subcommittee staff: "Here's this guy, almost a Nobel Prize winner, you walk in his office and see all these awards all over the walls-if he tells us he did something, are we going to question it?" (Staff Report, p. 19)

HHS contract attorney, interview with Subcommittee staff: "Believe me, I didn't know enough to lie." (Executive Summary, p. 53, Staff Report p. 19)

\section{PARTIAL LISTING OF DOCUMENTS DELAYED OR NEVER PROVIDED TO THE SUBCOMMITTEE BY HHS OR DOJ}

[From the Executive Summary, p. 14. "In addition to the documents listed below, a substantial number of significant documents were altered and/or redacted before they were provided by Gallo et al. to OSI" and hence to the Subcommittee.]

Never provided. OSI staff notes from the Gallo investigationdestroyed in 1992 by order of then-OSI Director Dr. Jules Hallum, despite an outstanding Subcommittee document request. (Executive Summary, p. 14)

Never provided. All documents from the office of Dr. Lowell Harmison, formerly HHS Science Advisor to the Assistant Secretary for Health and a major player in the HIV blood test dispute. By his own admission, the documents were removed by Dr. Harmison and allegedly discarded, on the occasion of his retirement from HHS in late 1987. (Executive Summary, p. 14)

Never provided. All documents from the office of C. McLain Haddow, formerly Chief of Staff to HHS Secretary Margaret Heckler and a major player in the early days of the blood test dispute. Haddow told Subcommittee staff he left all his documents in his office. Only a single Haddow document was provided to the Subcommittee by HHS. (Staff Report, p. 187) 
Never provided. All attorneys' notes from the U.S. Department of Justice.

Never provided. (a) LTCB data from the initial 1984 experiments showing the IP and LTCB prototype HIV isolates were genetically identical; (b) LTCB data associated with the unpublished 1984 Lancet manuscript that reported the IP and LTCB isolates were "independent"; (c) documents associated with the LTCB scientists' 1984 review of the Bryant et al. manuscript that reported the genetic identity of the IP and LTCB HIV isolates. (Executive Summary, p. 15; Staff Report, pp. 92, 118)

Withheld nearly one year. Numerous highly significant documents generated by or previously in the possession of former NCI Associate Director Dr. Peter Fischinger, including documents showing how NCI misled then-Assistant Secretary of Health, Dr. Edward Brandt, concerning the identity of the IP and LTCB HIV prototype isolates. The "Fischinger documents," known by the Subcommittee to exist, had been provided by NIH to a pharmaceutical firm in connection with a 1992 lawsuit. The documents were not provided to the Subcommittee despite repeated, specific requests. They finally were given up just hours before the Subcommittee staff visited the NIH campus to interview witnesses about the "missing" Fischinger documents. (Executive Summary, p. 41; Staff Report, p. 112)

Withheld nearly two years. Peter Fischinger's August 1985 "Major Areas of Oversight" memorandum to Dr. Gallo, showing Dr. Fischinger's concern with, among other things, the failure of Gallo and his associates to confirm they did not us LAV in isolating the LTCB's putative prototype virus "IIIb." (Executive Summary, p. 46; Staff Report, p. 173)

Withheld nearly two years. Memoranda to Dr. Harmison from NIH laboratory chief Dr. Malcolm Martin reporting Dr. Martin's laboratory data that pointed to the strong probability the IP and LTCB prototype HIV isolates were genetically identical, with the putative LTCB isolated derived from the IP, and not the reverse. One of these vitally important memoranda was located in Dr. Gallo's files, over three months after Dr. Gallo signed an affirmation that he had provided all responsive documents to the Subcommittee and asserting that: "I really do not know what Mr. Dingell is referring to in terms of documents not received relating to the patent." (Staff Report, p. 176) 
Withheld nearly two years. The "Myers documents," dating from 1987-1990, showing proof of the genetic identity of the IP and LTCB prototype HIV isolates. (Executive Summary, p. 15. Staff Report, p. 263)

Withheld nearly two years. All documents relating to Dr. Bernadine Healy's committee of "wise men," by which Dr. Healy attempted-and mostly failed-an end run of the "Richards committee." (Executive Summary, p. 57)

\section{§3. Subsequent Developments}

The Chicago Tribune reported on the Dingell Staff Report ("In the Gallo case, truth termed a casualty," 1 January 1995, p. 1), and followed this article by a scathing editorial "Defending the indefensible Dr. Gallo" (6 January 1995). A few days later, I received a fax from Gallo stating: "In view of your continued assassination of my character and the enormous amount of time you have put into distributing unfair and rediculous [sic] attacks on me, I trust that in fairness you will circulate these two enclosures ( 3 pages which follow), written by Bernadine Healy and my lawyer, Joseph Onek." I did circulate these documents, which I reproduce below, together with replies which Gallo did not send to me but which I received directly from the parties involved. I also included samples of false statements by Gallo and his lawyer (vide supra).

\section{LETTER FROM BERNADINE HEALY to the Chicago Tribune \\ 19 January 1995}

\section{No conspiracy in HIV controversy}

CLEVELAND-In his final spasm as outgoing chairman of the Energy and Commerce Committee, Rep. John Dingell (D-Mich.) heaved another package of fabrications and distortions. These latest accusations arrived in an allegedly unauthorized, "leaked," secret draft report on a three-year investigation of a controversy surrounding the 1984 discovery of the AIDS virus (HIV) reported by the Tribune Jan. 1 .

One hopes this marks the end of Dingell's deluded notions of a multi-administration conspiracy to protect Dr. Robert Gallo, one of the discoverers of HIV who also developed the blood test for 
HIV. At enormous taxpayer expense, Dingell has pursued Gallo and attacked anyone who has refused to join in his crusade.

The former chairman first accused me, as then-director of the National Institutes of Health, of "replacing" an employee of the NIH's Office of Scientific Integrity (OSI) who wrote a report that was "sharply critical of Dr. Gallo."

This employee was never replaced. On the contrary, before I arrived at the NIH, she requested and was given a new job in an unrelated department. She was also given leave at that time to complete her work on the Gallo case. I did ask her to revise the amateurish and poorly written report for style and structure, but when she complained that revision would change the meaning, I withdrew my request immediately. I subsequently accepted the employee's report which ironically, though critical of some of his actions, had always exonerated Dr. Gallo of misconduct.

Second, the former chairman contends that I "bypassed" the "conclusions" of an advisory committee in accepting the OSI report that exonerated Dr. Gallo. In fact, I was presented with several non-binding recommendations of advisory groups, all of which advised acceptance of the report except one. The one contrary recommendation came from a committee that refused to consider evidence or testimony from the accused.

I easily could have ignored all other findings in favor of the advice from the one flawed advisory committee. Instead, I made an independent judgment that, after careful review, seemed to me to be correct.

My unwillingness to be a pawn in the former chairman's smear campaign prompted further false accusations. An example is the third charge in his report, his invention of a conversation in which I told him that I felt I had to "save Bob [Gallo]." I never made such a preposterous statement.

As the head of an agency that was a frequent target of Dingell's witch-hunts, I saw first-hand the abuse of power by a long-time committee chairman and his staff acting as secret police, prosecutor, judge and jury under the old House rules. Americans would be shocked to learn of the clandestine tape recordings, document theft, threats, foul-mouthed verbal rantings and abusive closed-chamber interrogations of the former chairman and his staff of over 100 .

Immune from the Freedom of Information Act and the laws against libel and slander, Dingell and his staff operated in virtual secrecy, withholding any documents that displayed its methods of operation or contradicted its fabricated story line. This gave them carte blanche to make reckless and unsupported statements 
about people or institutions.

Let the actions of Dingell and his bloated staff be a memorial to what went wrong with Congress after 40 years of single-party rule.

Bernadine Healy

STAFF, CLEVELAND CLINIC FOUNDATION FORMER DIRECTOR, NATIONAL INSTITUTES OF HEALTH

\section{REPLY TO BERNADINE HEALY Chicago Tribune, 12 February 1995}

\section{Report found scientific misconduct}

Dr. Bernadine Healy's January 19, 1995 letter concerning the congressional subcommittee draft staff report in the Dr. Robert Gallo case was characteristically inconsistent with the facts. As former NIH and Subcommittee investigators in this case, we write to set the record straight.

Dr. Healy's orders for changes in the NIH Gallo report did not bear merely on the "style and structure" of the report. Independent memoranda to Dr. Healy from the then-Director of the NIH Office of Scientific Integrity (OSI) and the chief investigator (supported by the then-Deputy Director of $\mathrm{NIH}$ ) protested that Dr. Healy's ordered changes, "would be damaging and enervating" and would "significantly vitiate the findings" of the Gallo report.

Contrary to Dr. Healy's claim, the NIH Gallo report did not "always exonerate[d] Dr. Gallo of misconduct." The penultimate version of the draft report found Dr. Gallo guilty of scientific misconduct (in the controversy surrounding the discovery of the AIDS virus), while the final version of that report found that dr. Gallo "created and fostered conditions that gave rise to falsified/fabricated data and falsified scientific reports" and Dr. Gallo's actions "warrant significant censure."

Based on these findings and other contemporaneous situations of wrongdoing in the Gallo laboratory, Dr. Healy's predecessor decided to initiate a formal evaluation of Dr. Gallo's fitness to serve as an NIH laboratory chief. These plans, of course, were preempted by Dr. Healy's arrival at NIH.

Dr. Healy did indeed replace the NIH chief investigator in the Gallo case, ordering that the investigator be "reined in" and "make no further decisions" in the case. Moreover, Dr. Healy ordered an investigation of the chief investigator herself, an investi- 
gation that the then-OSI Director described in memoranda to NIH attorneys and Dr. Healy herself as "improper" and "a threatening intimidation."

The "flawed advisory committee" was in fact a panel of distinguished scientists nominated by the National Academy of Sciences to oversee the NIH investigation. Contrary to Dr. Healy's assertion, this committee examined extensive evidence submitted by Dr. Gallo and his associates.

Concerning her implication that partisan politics produced her stormy relationship with the subcommittee, Dr. Healy seems to have forgotten just how bipartisan the subcommittee was in its dealings with her. During the subcommittee's August 1991 hearing into Dr. Healy's firing of the Gallo chief investigator, as well as Dr. Healy's mishandling of a misconduct investigation at her own Cleveland Clinic Foundation, Rep. Thomas J. Bliley (RVa.), then the ranking Republican on the subcommittee, observed that Dr. Healy's mishandling of the Cleveland Clinic investigation $\therefore$..raises questions about Dr. Healy's willingness to vigorously pursue allegations of scientific misconduct...."

In short, contrary to her mutterings about "single-party rule," Dr. Healy's adversarial relationship with the Subcommittee was entirely of her own making.

Peter D. H. Stockton

(former investigator on the Subcommittee on Oversight and Investigation)

Suzanne W. Hadley, Ph.D.

(former OSI Deputy Director and chief investigator of the NIH

Gallo investigation, subsequently an investigator with the

Subcommittee on Oversight and Investigations) 


\section{The Cancer Letter \\ Vol. 21, No. 5, 3 February 1995}

Letter to the Editor

\section{Gallo Attorney: Subcommittee Report Full of Errors, "Drivel"}

To the editor:

It would require a volume to respond fully to all the errors in the draft report on the AIDS blood test patent as described in The Cancer Letter of Jan. 6. Here are just a few points your readers should consider:

1. The Institut Pasteur did file a patent application for an AIDS blood test several months prior to Dr. Gallo and his colleagues. The problem with the application is that it expressly stated that the test scored positive in only 20 percent of AIDS patients. In short, the test was essentially useless.

2. As a practical matter, there could be no AIDS blood test until the scientific community was convinced that a new retrovirus (now called HIV) was the cause of AIDS. It was Dr. Gallo and his colleagues who demonstrated the etiology of AIDS in four landmark papers published in Science in May 1984. Similarly, there could be no blood test until HIV isolates could be grown in significant quantity. It was Dr. Gallo's colleague, Dr. Popovic, who accomplished this breakthrough, as described in one of the four Science papers. Finally, there could be no blood test unless the test scored positive in most AIDS patients. Dr. Gallo and his colleagues described such a test in the Science papers. The information in the Science papers provided the basis for the Gallo blood test patent filed in April 1984.

3. Neither the Centers for Disease Control nor the Institut Pasteur had any credible results comparable to Dr. Gallo's at the time the Gallo blood test patent was filed. In fact, in May 1984, CDC and Pasteur scientists submitted a paper to Science (published in July 1984) describing a test that scored positive in only 41 percent of AIDs patients. The article also stated that "it is possible" that the French virus and the American virus were the same subtype. Thus, at the time the Gallo patent was filed, the Institut Pasteur did not have a comparable blood test and there was insufficient evidence to demonstrate that the French and American viruses were the same subtype.

4. Dr. Gallo and his colleagues did use the French virus HIV-Lai 
in their blood test. But this use was accidental in two senses. First, HIV-Lai accidentally contaminated the American isolate HTLV-IIIB just as it contaminated the isolated LAV-Bru in the Institut Pasteur and contaminated isolates in the laboratories of Dr. Robin Weiss and others. Second, Dr. Gallo's laboratory could have used a different isolate, RF, for the blood test. The draft report's suggestion that $R F$ was not ready demonstrates a total ignorance of the facts. RF was growing well by early 1984, as laboratory records attest. Dr. Gallo's laboratory did not send out HTLV-IIIB for use in the blood test until April 1984. Dr. Gallo's laboratory clearly could have scaled up RF for use in the blood test by April if it had chosen to do so.

5. The draft report's claim that Dr. Gallo and his colleagues hid information is laughable. Even before the patent application was filed, Dr. Gallo went to Paris and arranged for the Institut Pasteur and his laboratory to prepare joint papers concerning the French and American viruses. These papers were prepared, but were not published at the request of the French. In May 1984, only three weeks after the patent application was filed, Dr. Gallo provided the Institut Pasteur with a sample of HTLV-IIIB to work with. Dr. Gallo and his colleagues then conducted most of the studies that led to the discovery of the close similarity between the French and American viruses and then to the discovery of the dual contamination. It was Dr. Gallo and his colleagues who first reported that the AIDS virus, unlike HTLV I and II, was heterogeneous. It was Dr. Gallo's laboratory that reported the sequence of the HTLV-IIB isolate, thus making comparison to the French isolates possible. It was Dr. Gallo's laboratory that reported that HTLV-IIIB and the French isolates LAV-Bru were different. This led to the Institut Pasteur's belated discovery in 1991 that LAV-Bru had been contaminated by HIV-Lai in its laboratory in 1983. Finally, once the Institut Pasteur explained about the contamination that had occurred in its laboratory, Dr. Gallo promptly acknowledged that his laboratory had accidentally used HIV-Lai in its blood test. This acknowledgement was made in 1991, well before any studies by independent laboratories or Dr. Varmus' statement in 1994.

It is bad enough that The Cancer Letter devoted so much space to such drivel. But its use of Dr. Suzanne Hadley as a commentator is truly extraordinary. Dr. Hadley's bias and incompetence are well known: every major scientific misconduct report she has worked on has been thrown out. Perhaps The Cancer 
Letter will now rely on tobacco executives to provide commentary on the causes of lung cancer.

\section{Joseph Onek \\ Counsel for Dr. Robert Gallo \\ Crowell \& Moring}

Editor's Note: The Cancer Letter decided that in light of Mr. Onek's comments about her, Dr. Hadley was owed the opportunity to respond. Her response follows.

\section{Hadley: OSI Underestimated Magnitude of Gallo Case}

To the editor:

Mr. Onek would do well to examine the facts in the Subcommittee staff report, rather than trotting out yet again the same irrelevancies and unsubstantiable claims that for years have characterized his and Dr. Gallo's responses concerning these matters. Mr. Onek's claim that the Gallo laboratory could have used the RF isolate for its HIV blood test is just one example of numerous Gallo/Onek claims that are compellingly disproved by the evidence detailed in the staff report.

As for Mr. Onek's gratuitous, plainly silly comments concerning The Cancer Letter's choice of commentators, they hardly warrant a response. However, since Mr. Onek has raised the issue of competence of Office of Scientific Integrity investigations, I gladly take the opportunity to acknowledge that OSI missed the boat in one major scientific misconduct case, i.e. the investigation of Dr. Gallo and his colleagues. As the former chief investigator in the case, I can say with certainty that no one at OSI comprehended the extent, seriousness, and systematic quality of the falsehoods that were perpetrated in this case. Nor, certainly, did we comprehend the significance of the official imprimatur that years earlier had been stamped on these falsehoods. In short, we had no idea what we were up against.

The stakes became clear in the spring of 1991, when an OSI report that pointed out numerous false statements in the Gallo et al. patents and related US government pleadings was dismissed by NIH/HHS attorneys with the offhand comment that, "We don't think there's a problem here." Shortly after preparing this report, I was forced to resign as chief investigator in the Gallo case. 
Fortunately, thanks to Congressman John Dingell and the subcommittee, this was not the end of the matter. The full text of the subcommittee staff report is now available, on the WorldWide Web at the following URL number:

http://nyx10.cs.du.edu:8001/ wstewart/

The scientific community and the public finally can examine the evidence and make their own judgments about these important matters. They will find the staff report solid in all its findings.

Suzanne Hadley

Rockville, MD

\section{A LETTER FROM DINGELL TO VARMUS}

Copies of the Subcommittee Staff Report circulated widely; partly because of my mailing, and partly because others (such as Stewart-Feder) also publicized it. I received a letter from Kenneth Ryan $^{3}$ (postmarked 7 February 1995), acknowledging receipt of this Staff Report, and stating: "I will have it reproduced for all our Commission members. It obviously should inform our work and help in our deliberations. I am wondering whether the new congress will be at all interested in it. It will be interesting to see what the response of the scientific community will be. You are to be commended for taking the time and effort to deal with the scientific integrity issue."

Some documents pertaining to the Staff Report were sent by Stewart and Feder to Harold Varmus, the new Director of NIH. Hearing that Varmus was unhappy with the Staff Report, Dingell wrote to Varmus a letter dated 3 February 1995:

Dear Dr. Varmus,

I have received a copy of a January 23,1995 memorandum to you from Mr. Walter Stewart and Dr. Ned Feder, as well as their letter to Dr. Kenneth J. Ryan. They have enclosed a "draft report" that they claim was authored by staff of the Subcommittee on Oversight and Investigations.

We cannot vouch for the authenticity or accuracy of the

\footnotetext{
${ }^{3}$ Kate Macy Ladd Distinguished Professor of Obstetrics, Gynecology and Reproductive Biology, Harvard Medical School; Chairman of the Ethics Committee; Chairman of the Commission on Research Integrity for the Office of Research Integrity in the Public Health Service.
} 
papers provided to you. They were not reviewed, much less evaluated, by the staff director, the Chairman, or any other Member of the Subcommittee. While some staff time was spent developing a report, one early draft on the matter had been rejected by the Subcommittee staff director several months ago. Because of the election results and the resultant time and resource constraints imposed by the transition, and the enormity of the editing and fact-checking tasks needed to assure that a report on this topic met the standards of the Subcommittee, no report was issued. Drafts and relevant files on this inquiry were turned over to the incoming majority as a pending and uncompleted matter.

I hope that this information will be of use to you as you and others assess the "draft report" and respond to the requests made by Mr. Stewart and Dr. Feder.

Sincerely,

JOHN D. DINGELL

RANKING MEMBER

cc: Dr. Kenneth J. Ryan

The events recounted here ( $\$ 2$ and $\S 3$ ) were summarily and effectively described in a Science and Government Report article: "Dingell Ex-Staffers Release Critical Report on Gallo" (15 February 1995, p. 5). According to this article: "SGR hears that Varmus, not pleased with the [Dingell Staff] report, sought advice from Harriet S. Rabb, General Counsel of the Department of Health and Human Services, who also gets knocked in the report. Rabb took up the matter with Dingell's staff chief, Alan J. Roth, who from way back doubted the political value of Dingell's clashes with the scientific establishment. The cautious solution was Dingell's letter to Varmus, not wholly repudiating the report-which after all, was produced under Dingell's chairmanship-but casting doubt on its status as an official Congressional product."

I want to conclude here by emphasizing political, institutional, and journalistic responsibilities involved in Dingell's letter to Varmus. Nowhere in his letter did Dingell disavow the Staff Report itself. However, the letter lent itself at the time to interpretations discrediting the Staff Report. For example, Dingell wrote: "We cannot vouch for the authenticity or accuracy of the papers provided to you." (Dingell is here referring to the documents sent to Varmus by Stewart and Feder.) This sentence is an abdication 
of responsibility, but it does not assert that the Staff Report is deficient in any way. Nevertheless, the sentence sets a context for an innuendo subject to many interpretations, namely Dingell's subsequent statement that an "early draft on the matter had been rejected by the Subcommittee staff director several months ago." What does this rejection mean? For what reasons? Because the draft was 1,200 pages long (as I am told by a member of the staff at the time)?

I remind the reader of some official statements by Dingell in the past:

- Dingell's introduction to the Harmison hearings $(21$ July 1993), where he stated: "When the U.S. Government sought a patent on its alleged 'discoveries' relative to the HIV blood test, officials apparently withheld from the U.S. Patent Office information directly and materially relevant to the examination of the Government's patent applications-information showing the claimed invention actually had been made long before by other scientists."

- Dingell's very critical letter to the 1992-NIH Director Bernadine Healy, dated 26 November 1992, as reported in Science and Government Report (cf. §1).

- Dingell's letter to the 1994-NIH Director Harold Varmus dated 23 February 1994, where he stated: "The contents of the Myers/NIH correspondence are summarized in a Subcommittee staff memorandum attached to this letter. The substance of the 'Myers' documents (and their greatly belated submission to the Subcommittee, not to mention the fact that the documents were never provided to OSI, ORI or the HHS OIG) are matters of considerable concern. The contents of these documents, particularly in light of the conclusions of the Richards Committee and many members of Dr. Healy's irregular secret committee, raise renewed concerns about Dr. Gallo's veracity and forthrightness on these matters."

In contrast with these earlier positions, Dingell's 3 February 1995 letter to Varmus is so ambiguously worded as to promote interpretations which would undermine his Staff Report. I regard such a letter as a betrayal of what he stood for over the last several years, since his Subcommittee started investigating the Gallo case, following the Baltimore case.

Fortunately, the credibility of the Staff Report does not depend on Dingell or anyone else. Indeed, the Staff Report itself does not ask to be taken on trust. It confirms the ORI Offer of Proof and the HHS Inspector General's Memorandum as far as they went. It 
gives factual documentation, putting an entire story together, and refers meticulously to the record, which is verifiable. Anyone can check out its factual assertions, as well as the direct quotes from Gallo himself or his lawyer.

Dingell trumpeted over several years in the name of truth, and in the name of scientific and political responsibility. He was supported and encouraged by a few scientists who went on the line despite a hostile reaction by scientists at large. He used his staff, and persons such as Suzanne Hadley who made heavy professional commitments. After all these dealings, for him to have issued a letter to Varmus such as the one he did on 3 February 1995, lending itself to interpretations stemming from ambiguities and innuendos contained in the letter without his actually taking responsibility for the interpretations, which some people are using in early 1995 to discredit everything he claimed he stood for in the last few years, is a betrayal of truth, of scientific and political responsibility, and of the people who trusted him. 